\title{
QUALITÄTSSICHERUNGSSYSTEME IM TÜRKISCHEN AgribusinesS
}

\author{
Dissertation \\ zur Erlangung des Doktorgrades \\ der Fakultät für Agrarwissenschaften \\ der Georg-August-Universität Göttingen
}

vorgelegt von

\section{Tuba Pekkirbizli}

geboren in Konya (Türkei)

Göttingen, im November 2014 
D7

1. Referent: Prof. Dr. Ludwig Theuvsen

2. Referent: Prof. Dr. Achim Spiller

3. Korreferent: Prof. Dr. Elke Pawelzik

Mündliche Prüfung: 14. November 2014 


\section{Inhaltsverzeichnis}

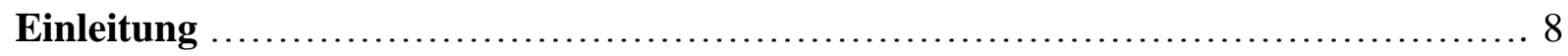

Teil 1: Darstellung der türkischen Agrarwirtschaft und Qualitätssicherung ................ 12

Teil 2: Food safety and quality assurance systems in Turkish agribusiness:

An empirical analysis of determinants of adoption .......................... 45

Teil 3: EU requirements for food safety and quality systems:

Determinants of perceptions ....................................... 73

Teil 4: Muslimische Konsumenten in Deutschland: Kenntnis und Bedeutung der Halal-Kennzeichnung . ......................................... 96

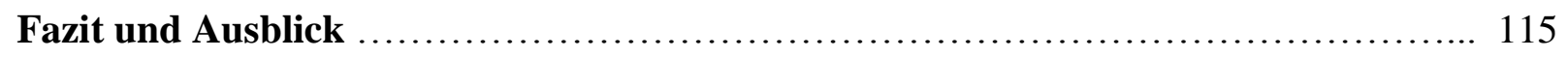

\section{Anhang:}

1. Fragebogen für Qualitätssicherungssysteme in der türkischen Agrar- und Ernährungswirtschaft ...................................... 120

2. Deskriptive Ergebnisse ................................................ 145

3. Fragebogen zum Konsumverhalten von Muslimen in Deutschland bei Halal-Lebensmitteln: Fallbeispiel Göttingen .... 


\section{„Sabır ăgacı çizdim ben!}

Sanki karanlık bir tünelde gidiyorum, tünelde hiç bir ışık yok

$$
\text { ve çok dar. }
$$

Sürüne sürüne gitmişim, gitmişim, sonra bir dışarı çıktım,

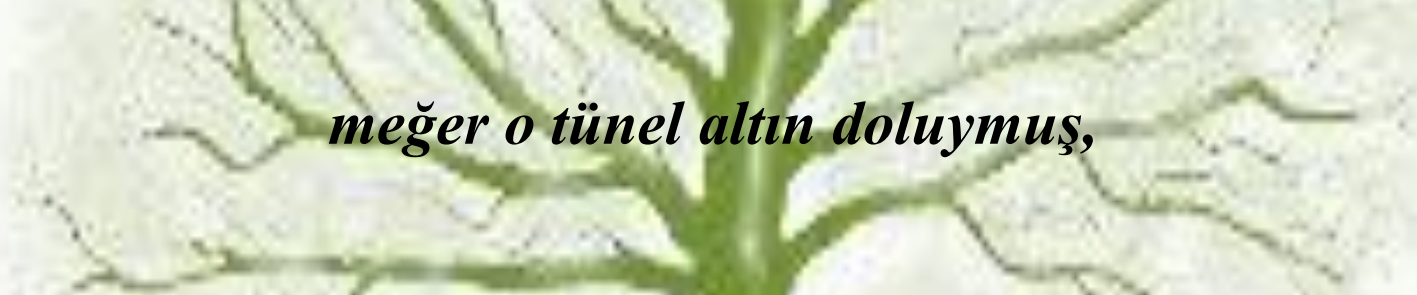

bir çıktım ki her tarafimı altın tozcukları kaplamış,

$$
\text { parlyorum!" }
$$




\section{Danksagung:}

Das war ein Abenteuer!! So viele aufregende Jahre mit guten Zeiten und schlechten Zeiten. Manchmal im tiefsten Brunnen, manchmal so hoch wie auf den weichen Wolken. Es ist vollbracht und ich habe es tatsächlich geschafft! Ich habe so lange gekämpft und nun wurde mein Traum endlich wahr ...!

Ich habe sehr viel erlebt und viele Erinnerungen haben sich angesammelt, sodass es viele Menschen gibt, bei denen ich mich an dieser Stelle herzlich bedanken möchte.

Ein ganz besonderes Dankeschön geht zunächst an meinen Doktorvater Prof. Dr. Ludwig Theuvsen. Ich bedanke mich ganz herzlich für das große Vertrauen, die ewige Geduld und großzügige Hilfe. Er hat seine Hoffnung, die er in mich setzte, nie verloren.

Er hat mir nicht nur einen Platz an der Universität gegeben, sondern auch die Chance eröffnet an seinem Lehrstuhl zu arbeiten und somit ein Teil dieser Familie zu sein. Er hat es immer wieder geschafft, ruhig zu bleiben und gute Lösungen zu finden, insbesondere, wenn ich in einer Phase der Verzweiflung war. Ohne seine Hilfe und Unterstützung hätte ich es nicht geschafft! Ein großes Dankeschön Herr Theuvsen, für Ihre Geduld, Ihr Verständnis und Ihre unendliche Hilfe.

Darüber hinaus bedanke ich mich bei Herrn Prof. Dr. Achim Spiller für die Übernahme meines Korreferats und meines Zweitgutachtens. An dieser Stelle möchte ich mich auch ganz herzlich bei Frau Prof. Dr. Pawelzik für Ihr Verständnis bedanken.

Martina Reichmann, du bist mein Schutzengel! Du hast seit langer Zeit alles korrigiert, was ich auf Deutsch geschrieben habe, und dies immer mit grenzenloser Geduld und großer Leidenschaft. Du hast mir in schwierigen Zeiten in jeglichen Angelegenheiten geholfen. Du warst eine sehr gute Zuhörerin und eine sehr gute Ratgeberin, die immer auf mich Acht gegeben hat und mir mit Rat und Tat zur Seite stand. Dein berühmter Satz, den ich vielleicht tausendmal von dir gehört habe: „Ich will nur das Beste für dich“. Du hast ein sehr großes Herz und du bist sehr wichtig für mich. Ich werde deine Anregungen immer wieder, sowohl in meinem Privatleben als auch in meinem zukünftigen Berufsleben nutzen. Du hast mich so viel gelehrt, mir so viele Sachen beigebracht. Besten Dank für alles!

Dr. Mohamad Isam Almadani, es hat viel Spaß gemacht, mit dir zusammenzuarbeiten. Vielen Dank für Deine zahlreiche fachliche Hilfe und Unterstützung. 
Bedanken möchte ich mich weiterhin bei Tilman Bischof, einem sehr guten Freund, und seiner Familie. Vielen Dank für die vielen Korrekturarbeiten. Die vielen schönen Abende, insbesondere an Weihnachten neben dem Tannenbaum und der Katze und mit der schönen Wärme im Haus der Familie Bischof, werde ich nie vergessen.

Frau Dr. Susanne Ohrt hat mir freundlicherweise eine Arbeitsstelle gegeben und hatte immer sehr wichtige Ratschläge für mich. Durch Frau Ohrt habe ich eine andere wissenschaftliche Welt kennengelernt. Liebe Susanne, vielen lieben Dank für Deine Hilfe und Deine tolle Unterstützung. Ebru Cetin, auch wenn wir uns erst seit einer kurzen Zeit kennen, warst Du in der letzte Phase meiner Promotion in Göttingen eine große Hilfe für mich. Vielen Dank, dass du auf mich Acht gegeben hast und für deine tolle Freundschaft.

Dr. Pinar Öz, Dr. Ulrike Zschache, Dr. Anja Voss, Dr. Christina Gawron, Dr. Sören Henke, Janina Müller, Maria Näther, Dr. Verena Otter, Behzad Alizadeh Kashani, Nina Gerdes und viele andere, Ihr seid alle meine guten Freunde. Vielen Dank für eure tolle Unterstützung und die schönen Erinnerungen. Frau Gremmes, ich bedanke mich ganz herzlich bei Ihnen; Sie haben mir immer wieder geholfen und mich jederzeit unterstützt.

Bianka Rieck und Monika Scholz, unsere Bibliotheks-Mädchen; ihr hattet immer so ein großes Verständnis bei den verspäteten Zeitschriften. Dagmar Krendl, Wolfgang Peinemann vielen Dank für Eure Hilfe und die schönen Erinnerungen.

Anke \& Stephan Röpkes aus Ostfriesland, Ihr habt in meiner schwierigen Zeit bei VW in Emden immer Eure Tür geöffnet und auf mich aufgepasst. Ich danke euch dafür!

Ich werde mein Leben in Göttingen nie vergessen, ich bin hier zu derjenigen geworden, die ich jetzt bin; hier habe ich meine Augen geöffnet und hier bin ich gewachsen! Ihr seid wie meine Familie geworden. Es ist sehr schwierig, sich nun nach der langen Zeit zu verabschieden, aber ich weiß, dass, wenn man eine Sache beginnt, man diese schließlich auch vollenden muss.

Mein Opa, canim dedem und mein Engel Mustafa, ihr bleibt ewig in meinen Erinnerungen.

Der größte Dank gebührt allerdings meiner Familie. Sie schenkt mir seit 31 Jahren das schönste und wichtigste, nämlich endlose Liebe und grenzenlose Aufmerksamkeit! Mein Daddy, er ist der beste Assistent der Welt, ohne Dich hätte ich meine empirische Untersuchung nicht erfolgreich zu Ende führen können. Papa, Du warst immer für mich da! Du hast jeden Tag unermüdlich Deine Erfahrungen und Deine Ratschläge mit mir geteilt, vielen lieben Dank! 
Meine Mutter, du bist mein Engel, ohne Deine Motivation und Deine Gebete hätte ich nicht weitermachen können. Du hast mir grenzenlose Liebe gegeben. Mein Bruder Yusuf, ich bin sehr glücklich, dass ich so einen Bruder wie Dich habe. Vielen Dank, dass Du Dir jederzeit stundenlang meine Probleme angehört hast. Du bist ein toller Mensch! Ich widme diese Arbeit meiner wundervollen Familie.

Ich beende meine Danksagung mit den Worten eines sehr berühmten Dichters, die sehr gut auf meinen Lebenslauf passen: “Hamdım, piştim, yandım...” Mevlânâ Celâleddîn- i Rûmî.

Göttingen, im Oktober 2014

Tuba Pekkirbizli 


\section{Einleitung}

Die Lebensmittelsicherheit hat in der türkischen Agrar- und Ernährungswirtschaft in den letzten Jahren erheblich an Bedeutung gewonnen. Dies ist vor allem der Tatsache geschuldet, dass die Türkei im Jahre 2005 als Beitrittskandidat der Europäischen Union (EU) akkreditiert wurde, denn die EU ist mit Abstand der wichtigste Handelspartner der Türkei für Agrarprodukte. Die Türkei hat im Jahre 2012 im Agrarsektor einen Handelsüberschuss von 3,6 Mrd. Euro allein mit den EU-27 Ländern erwirtschaftet (Eurostat 2013). Diese Entwicklung wurde vorangetrieben, indem bestehende Handelshemmnisse durch den türkischen Beitritt zur Zollunion im Jahre 1996 abgebaut wurden. Um diesen Kostenvorteil gegenüber Konkurrenten aus Nicht-EU-Ländern langfristig zu halten, könnten alle Entwicklungen im Bereich der Qualitätssicherheit der türkischen Agrar- und Ernährungswirtschaft von strategischer Bedeutung sein.

Das Dissertationsprojekt befasst sich auf der Grundlage einer empirischen Untersuchung mit Zertifizierungssysteme und anderen Formen der Qualitätssicherung (z.B. HACCP-Konzepte) im türkischen Agribusiness. Eine besondere Beachtung finden die Einflussgrößen auf die Zertifizierungsentscheidungen und die Wahrnehmung von Zertifizierungssystemen und Qualitätsanforderung, die in der türkischen Agrar- und Ernährungswirtschaft existieren. Dazu wurden anhand einer Online-Befragung Daten von weiterverarbeitenden Exporteuren und Lebensmittelunternehmen gesammelt, systematisiert und ausgewertet. Der Fragebogen wurde bei dem Online Befragungsnetzwerk Unipark EFS Survey eingetragen, woraufhin zahlreiche Unternehmen den Link zur Online-Befragung erhalten haben. In einigen großen Städten in Zentralanatolien wurden darüber hinaus Unternehmen des Handels und der Weiterverarbeitung mit Getreide, Hülsenfrüchte, Ölsaaten, Mahl- und Schälmühlen, Back- und Teigwaren sowie Süß- und Schokoladenwaren im Rahmen der Untersuchung persönlich besucht. Weiterhin fanden neben persönlichen Besuchen auch telefonische Kontaktaufnahmen statt.

Auf diese Weise sollten der Status Quo der Lebensmittelqualität und -sicherheit einschließlich Zertifizierungssysteme in der Türkei, die Kosten der Zertifizierung sowie Entwicklungstendenzen analysiert werden. In dieser Arbeit wurden ferner die Anforderungen der EU untersucht es wurde analysiert ob diese Anforderungen von den türkischen Exporteuren Herausforderung wahrgenommen werden. Der nächste wesentliche Aspekt dieser Arbeit gilt der Bewertung der gebräuchlichen Zertifizierungssysteme zur Analyse der Stärken und Schwächen und der Ableitung geeigneter Anpassungsstrategien zur Verbesserung der Exportfähigkeit von türkischen Unternehmen. Dabei geht es vor allem um die Nutzen-Kostenrelation der 
Zertifizierungssysteme, sowie um die Probleme mit dem Umgang mit Zertifizierungs- und anderen Qualitätssicherungssystemen und Herausforderungen, die sich mit Einführung bzw. Beibehaltung der Zertifizierungssysteme ergeben. Entwickeln sich die hohen Anforderungen die aus den europäischen Abnehmerländern an türkische Unternehmen gerichtet werden als Marktchance oder als Markteintrittsbarriere und wie können diese ggf. genutzt bzw. gemindert werden? Weiterhin soll überprüft werden, welche Rolle die Qualitätssicherung als Wettbewerbsstrategie erfüllt.

So ist es ungewiss, ob es möglich ist in Gebieten, die in den letzten Jahren häufig von Dürre betroffen waren, Standards für Qualität und Sicherheit zu garantieren. Fraglich in diesem Zusammenhang ist außerdem, ob die externen Einflüsse wie Z.B. der internationale Wettbewerb für die Einführung von Zertifizierungs- und anderen Qualitätssicherungssystemen ausschlaggebend sind oder ob nicht auch interne Einflüsse, etwa die türkische Gesetzgebung ebenso viel Einfluss auf die Entwicklung der allgemeinen Lebensmittelsicherheit ausüben. Eine andere Frage wäre hier, inwieweit die Akzeptanz der Systeme durch die Unternehmen und die Effizienz der Mitarbeiter Auswirkungen auf die Implementierung z.B. von Zertifizierungssystemen haben können. So könnte auch in der Türkei bei den Abnehmern der Wunsch nach mehr Lebensmittelsicherheit und -qualität steigen, welches nicht zuletzt durch inländische Lebensmittelkrisen vorangetrieben wird. So werden die Endverbraucher in der Türkei bspw. immer wieder durch falsche Inhaltsangaben bei weiterverarbeiteten Lebensmitteln getäuscht.

Ferner könnte die Gewinnerwartung einige Weiterverarbeiter und Erzeuger dazu veranlassen, Zertifizierungssysteme als Nischen- oder Differenzierungsstrategie zu implementieren, auch wenn diese nicht nach Europa oder ins sonstige Ausland exportieren, um damit den Grad der Internationalisierung zu erhöhen. Voraussetzung dafür ist jedoch, dass die gebräuchlichen Zertifizierungen der jeweiligen Abnehmerländer auch bekannt sind.

\section{Problemstellung}

Die EU-Beitrittsverhandlungen mit der Türkei begannen im Jahre 2005, sodass die Türkei den vollständigen Besitzstand der EU übernehmen musste. Das Regelwerk enthält 33 Beitrittskapitel, von denen vor allem Kapitel 11 „Landwirtschaft und ländliche Entwicklung“ sowie Kapitel 12 „Lebensmittelsicherheit, Veterinärpolitik und Pflanzenschutz“ von Bedeutung sind. Die Verhandlung über Kapital 12 wurde am 30.06.2012 aufgenommen (Europäische Kommission 
2013b). Diese Anpassungen werden von der EU finanziell und technisch unterstützt. Das Instrument dieser Heranführungshilfe wird IPA genannt (Instrument for Pre-Accession Assistance) und besteht aus fünf Komponenten:

1. Übergangshilfe und Aufbau von Institutionen

2. Grenzübergreifende Zusammenarbeit

3. Regionale Entwicklung

4. Entwicklung der Humanressourcen

5. Entwicklung des ländlichen Raums

Die Komponenten 3 und 5 sollen vor allem auf die Umsetzung der Agrarpolitik nach dem Beitritt vorbereiten. Die Europäische Kommission hat vorgestellt, wie die EU weiter mit IPA II mit über 11 Mrd. Euro die Reformanstrengungen in den westlichen Balkanländern und der Türkei für die nächsten 7 Jahre unterstützt. Die Türkei wird mit insgesamt 4,4 Mrd. Euro den größten Anteil von IPA II für den Zeitraum 2014- 2020 erhalten, gefolgt von Serbien (IPA II 2014).

Die IPA II-Fonds wurden in der Türkei eigenständig im Rahmen des dezentralen Durchführungssystems eingesetzt. Das Ministerium für EU-Angelegenheiten ist für die Beschaffung, Auftragsvergabe und Auszahlung für IPA-Projekte zuständig, wobei keine vorherige Bewertung durch die Kommission erfolgt. Alle Finanzhilfevorschläge müssen zuerst den türkischen Behörden unterbreitet werden (Ministerium für EU-Angelegenheiten 2014).

Das IPA-Programm bietet der Türkei somit die Chance, ihre volkswirtschaftlichen strukturellen Probleme zu mindern. Einer der wichtigen Schwerpunkte der EU-Unterstützungen ist die Übernahme von EU-Rechtsvorschriften in den Bereichen Verkehr, Landwirtschaft, Lebensmittelsicherheit, Umweltschutz, Klimawandel und Energie.

Die Agrarwirtschaft trägt zum türkischen Bruttoinlandsprodukt fast $10 \%$ bei und beschäftigt sogar 25,5\% der gesamten Arbeitskräfte (FAO 2012). Dieses liegt zum Teil daran, dass die Arbeitskraft häufig unbezahlte Familienarbeit ist. Des Weiteren ist die Arbeitsproduktivität gering, da diese Familienbetriebe oft zu klein sind, um ein höheres Niveau an Effizienz zu erlangen. Es wird kaum über den Eigenbedarf hinaus produziert. Investitionen und Modernisierungen bleiben daher vielfach aus. Das macht sich vor allem in den ländlichen Gebieten bemerkbar. Hier müssen vor allem Trink- und Abwassersysteme sowie die Infrastruktur 
ausgebaut werden. Außerdem sind gerade diese Regionen durch eine Abwanderung von qualifizierten Arbeitskräften gekennzeichnet. Dazu kommen schwierige natürliche Produktionsbedingungen in den Bergen und in den Waldgebieten (vgl. EU 2007).

\section{Zielsetzung der Dissertation}

Ziel der Arbeit ist es, die Auswirkungen aktueller Entwicklungen im Bereich der Lebensmittelsicherheitssysteme für Agrarprodukte und Lebensmittel in der Europäischen Union auf türkische Unternehmen, die in die Europäische Union oder andere Länder exportieren, zu untersuchen und geeignete Anpassungsstrategien zu entwickeln.

Im Einzelnen umfasst diese Zielsetzung die folgenden Teilziele:

- Darstellung der türkischen Agrar- und Ernährungswirtschaft: Umfang, Entwicklung, Strukturen, Produktspektrum, räumliche Verteilung, Importe und Exporte sowie internationalen Verflechtungen;

- Ermittlung des Status quo und der Entwicklung der Qualitätssicherungssysteme für Agrarprodukte und Lebensmittel in der türkischen Agribusiness unter besonderer Berücksichtigung von (a) gesetzgeberischen Maßnahmen (b) privatwirtschaftlichen Initiativen, insbesondere Zertifizierungssystemen;

- Empirische Erhebung des Status quo der Zertifizierungs- und anderer Qualitätssicherungssysteme in der Agrar- und Ernährungswirtschaft in der Türkei;

- Stärken-/Schwächen-Analyse der Lebensmittelsicherheit in der türkischen Agrar- und Ernährungswirtschaft unter besonderer Berücksichtigung der Anforderungen in der EU. 


\section{Teil 1: Darstellung der türkischen Agrarwirtschaft und Qualitätssicherung}

1. Darstellung der türkischen Agrar- und Ernährungswirtschaft

1.1 Die Struktur der türkischen Agrarwirtschaft

1.2 Produktionsstruktur

1.3 Handelbeziehungen zwischen der Türkei und der EU

2. Qualitätssicherung in der türkischen Agrar- und Ernährungswirtschaft
a) Ist-Zustand in der Qualitätssicherheit nach nationalen gesetzlichen Vorgaben
b) Ist-Zustand in der Qualitätssicherung in der Türkei nach internationalen Standards
c) Zertifizierungssysteme als Möglichkeit der Qualitätssicherung
d) Systematisierung von Zertifizierungssystemen

3. Qualitätssicherung für muslimische Verbraucher

4. Aufbau der Arbeit

5. Literaturverzeichnis 


\section{Darstellung der türkischen Agrarwirtschaft}

\subsection{Die Struktur der türkischen Landwirtschaft}

Die Türkei ist eine kleinasiatische Halbinsel und der westlichste Punkt des asiatischen Kontinents mit einer Gesamtfläche von 778,997 km². Davon ist $98 \%$ kontinentale Landfläche, von der etwa 28,5\% landwirtschaftlich genutzt werden. $34,4 \%$ der Fläche besteht aus Waldgebieten. Die am 29. Oktober 1923 proklamierte Türkische Republik fungiert als Schnittpunkt der drei Kontinente Europa, Asien und Afrika. Geographische Gebiete der Türkei sind die Marmara-Region, Zentralanatolien, die ägäische Region, die Mittelmeer Region, die Schwarzmeerregion, Südostanatolien und Ostanatolien. Produziert werden in der Türkei vor allem Getreide, Baumwolle, Tabak, Obst und Gemüse, Zuckerrüben sowie Schaf- und Ziegenfleisch. Zudem ist die Türkei Weltmarktführer bei Haselnüssen. In der Türkei gibt es knapp 4 Mio. landwirtschaftliche Betriebe. Davon konzentrieren sich 3,6\% allein auf Tierproduktion, während 96,4 \% über beides, pflanzliche und tierische Produktion verfügen. Die durchschnittliche Größe der landwirtschaftlichen Betriebe liegt bei 5,9 Hektar. 35 \% der Betriebe haben eine Größe von 0-2 Hektar, 32 \% eine Größe von 2-5 Hektar, 28 \% eine Größe von 5-20 Hektar und nur $5 \%$ eine Größe von 20 Hektar und mehr (vgl. Vural et al. 2007).

\subsubsection{Zentralanatolien}

Dieses Gebiet hat ein halbtrockenes Klima und besteht zu großen Teilen aus Steppe. Außerdem ist Zentralanatolien die flachste Region der ganzen Türkei und wird durch vulkanische Berge begrenzt, die Regenwolken und somit auch Niederschlag aus diesem Gebiet fernhalten (vgl. Sen 1986). Zentralanatolien hat eine landwirtschaftliche Nutzfläche von 7,96 Mio. Hektar und eine Anbaufläche von 4,7 Mio. Hektar. Hauptsächlich werden hier Weizen, Gerste mit einem Anteil von 39\% der gesamttürkischen Produktion, Roggen, grüne Linsen, Bohnen, Kartoffeln, Zuckerrüben, Wein und Kichererbsen erzeugt (vgl. Burrell et al. 2005). Insgesamt werden in dieser Region 5,5 Mio. Tonnen Getreide produziert mit einem Weizenanteil von 2,5 Mio. Tonnen. Landwirtschaftliche Probleme ergeben sich durch eine starke Bodenerosion und einen erhöhten Salzgehalt in der Erde, welche den Anbau von Obst und Gemüse erschweren. Aufgrund dessen ist diese Region auf Schaf und Ziegenzucht spezialisiert, insbesondere die Haltung von Angora-Ziegen und Angora-Kaninchen, welche in der Hauptstadt Ankara ihren Anfang nahm (vgl. Turkish Statistical Institute 2006). 


\subsection{2 Ägäische Region}

Diese Region hat eine landwirtschaftliche Nutzfläche von knapp 3 Mio. Hektar und eine Anbaufläche von 1,9 Mio. Hektar. Das Mittelmeerklima in diesem Gebiet begünstigt vor allem die Produktion von Obst wie Zitrusfrüchten, Feigen mit 233.000 Tonnen, Bananen und Trauben. Weiterhin werden Sesam, Oliven mit 1.076.844 Tonnen, Reis und Tabak erzeugt (vgl. Turkish Statistical Institute 2006). Auch die Baumwollproduktion ist hier von herausragender Bedeutung. Die Türkei gehört mit einer Produktion von 850 Tsd. Tonnen Baumwollfasern jährlich zu den sechs größten Weltmarktlieferanten. Die Ägäische Region erzeugt dabei rund die Hälfte der gesamttürkischen Produktion, welche für die heimische Textilindustrie verwendet wird, da diese zugleich als qualitativ hochwertigste gilt (vgl. Türkisches Ministerium für Industrie und Handel 2010). Die landwirtschaftlichen Arbeiter sind hier verhältnismäßig gut ausgebildet und der technische Fortschritt ist hoch, wie zum Beispiel die Produktion in Gewächshäusern. Ein Großteil der erzeugten Feigen und Oliven aus dieser Region werden exportiert, sodass auch dieses Gebiet als ein Handelszentrum gilt. Nach der Landwirtschaft ist die Tourismusbranche eine weitere starke Einkommensquelle in diesem Gebiet (vgl. Sosyalokulu 2010).

\subsubsection{Marmara-Region}

Diese Region hat unter den sieben geographischen Gebieten die kleinste Fläche und ist zugleich die bevölkerungsreichste Region. Dies liegt nicht nur an der 12 Mio.-Metropole Istanbul, sondern auch an den hohen Zuwanderungszahlen, die für die ganze Region gelten (vgl. Sosyalokulu 2010). Zudem ist das Verhältnis zwischen Gesamtfläche (3.3 Mio. Hektar) und tatsächlicher landwirtschaftlicher Nutzfläche (2,5 Mio. Hektar) in der Marmara-Region höher als in allen anderen geographischen Gebieten der Türkei. Daneben gilt die Marmara-Region als Handelszentrum der Türkei und besitzt außerdem eine bedeutende Textilindustrie. Die Landwirtschaft ist hier verhältnismäßig hoch entwickelt. Dennoch reicht die Produktivität gemessen an der Bevölkerungsdichte nicht aus. $73 \%$ der gesamten Sonnenblumenproduktion der Türkei und $30 \%$ der Maisproduktion befindet sich in dieser Region. Des Weiteren werden Weizen, Zuckerrüben, Haselnüsse Oliven, und verschiedenes Gemüse erzeugt. Außerdem gewinnt die Weinproduktion immer mehr an Bedeutung (vgl. Turkish Statistical Institute 2006). 


\subsubsection{Mittelmeerregion}

$24 \%$ des türkischen Waldaufkommens befindet sich in diesem Gebiet. Die Mittelmeerregion hat eine landwirtschaftliche Nutzfläche von 2,5 Mio. Hektar und eine Anbaufläche von 1,8 Mio. Hektar. Aufgrund der Klimabedingungen lassen sich hier bestimmte Erzeugnisse besonders gut anbauen. So werden Zitrusfrüchte und Erdnüsse zu $88 \%$, Sesam zu 80\%, Anis zu 65\%, Gemüse zu $26 \%$, Baumwolle zu $35 \%$ und Bananen gar zu fast $100 \%$ in dieser Region produziert. Des Weiteren werden Mohn und Tabak angebaut. Dabei werden Baumwolle und Reis vor allem in Çukurova und Bananen sowie Zitrusfrüchte in Antalya produziert. Als Besonderheit gilt Rosenöl aus diesem Gebiet mit einer jährlichen Produktionsmenge von 6.204 Tonnen Rosenblättern, woraus sich 1.465 Tonnen Rosenöl ergeben. Die hohen Temperaturen in diesem Gebiet stellen ein Problem und zugleich eine Chance dar. Im Sommer müssen die Felder künstlich bewässert werden. Im Winter jedoch können weiterhin Gemüse und Obst angepflanzt werden. Auch die Produktion in Gewächshäusern wird hier betrieben. Ferner ist die Tourismusbranche sehr wichtig in dieser Region. Pro Jahr gibt es um die 3 Millionen Besucher (vgl. Turkish Statistical Institute 2006).

\subsubsection{Schwarzmeerregion}

Dieses Gebiet hat im Jahr durchschnittlich am meisten Niederschlag und besitzt $25 \%$ der gesamten Waldfläche der Türkei. Eine wichtige Einnahmequelle für den Lebensunterhalt stellt die Fischerei dar. Auch der Agrartourismus gewinnt in den letzten Jahren immer weiter an Bedeutung. Die landwirtschaftliche Nutzfläche, die 2,9 Mio. Hektar umfasst, ist zumeist hügelig und auf kleine Parzellen verteilt. Erzeugt werden auf einer Anbaufläche von 1,8 Mio. Hektar Mais, Tabak, Haselnüsse, schwarzer Tee, Reis, Zuckerrüben und Obst, insbesondere Äpfel. Spitzenreiter der Erzeugung stellen vor allem schwarzer Tee mit fast $100 \%$ und Haselnüsse mit $85 \%$ der gesamttürkischen Produktion dar (vgl. Turkish Statistical Institute 2006). Die Haselnussproduktion hat außerdem eine starke sozioökonomische Bedeutung, auch für die anderen Regionen der Türkei, denn sie bietet vielen Menschen eine Möglichkeit, zur Erntezeit Arbeit zu bekommen. Insgesamt werden 219.345,853 kg Haselnüsse exportiert. Hauptabnehmer ist die Bundesrepublik Deutschland mit 54.822,885 kg (vgl. Generalsekretariat des Schwarzen Meeres Exporters Association 2009). 


\subsubsection{Südostanatolien}

Für die Landwirtschaft gibt es in Südostanatolien, welches eine landwirtschaftliche Nutzfläche von 3,3 Mio. Hektar und eine Anbaufläche von 2,6 Mio. Hektar hat, einige Problematiken, insbesondere wegen der erschwerten Klimabedingungen. Südostanatolien ist mit einer Durchschnittstemperatur von $19,5^{\circ} \mathrm{C}$ die heißeste Region in der Türkei. Dazu gibt es nur wenig Niederschlag und ein ungenügendes Bewässerungssystem. Aus diesem Grunde ist gerade die Viehzucht, vor allem Schaf- und Ziegenzucht, hier stark vertreten. Des Weiteren werden Pistazien mit einer jährlichen Produktionsmenge von 47.724 Tonnen, von denen große Mengen exportiert werden, Hülsenfrüchte, insbesondere rote Kichererbsen, Baumwolle und Weintrauben produziert (vgl. Turkish Statistical Institute 2006). Um den Ausbau der Bewässerung landwirtschaftlicher Flächen sowie der landwirtschaftlichen und städtischen Infrastruktur voranzutreiben, gibt es seit dem Jahr 2000 das Südostanatolien-Projekt. Ferner umfasst die GAP (Güneydoğu Anadolu Projesi) die Bereiche Stromgewinnung, Forstwirtschaft, Bildung und Gesundheit (vgl. GAP 2010).

\subsubsection{Ostanatolien}

Ostanatolien ist mit seiner landwirtschaftlichen Nutzfläche von 2,9 Mio. Hektar die höchst gelegene Region in der Türkei, welche viele Flüsse, jedoch wenig landwirtschaftliche Fläche aufweist. Die Infrastruktur ist ungenügend und die Zahl der Abwanderungen aus den Reihen der jüngeren Landbevölkerung ist sehr hoch. Auf einer Fläche von 2 Mio. Hektar werden hauptsächlich Getreide wie Weizen und Gerste, aber auch Zuckerrüben, Kartoffeln, Maulbeeren und Rote Bete angebaut. Als Besonderheiten sind hier noch Aprikosen und traditioneller orientalischer Tabak zu nennen (vgl. Turkish Statistical Institute 2006). Auch der KebanStaudamm, der am Euphrat liegt, ist aus zwei Gründen sehr wichtig für dieses Gebiet. Einerseits liefert er 6,2 Milliarden Kw. pro Jahr und bietet eine gute Technik zur Bewässerung, andererseits erfüllt das Kraftwerk eine sozioökonomische Rolle, da es auch unausgebildete Menschen in Lohn und Brot bringt. Außerdem findet man hier noch Viehzucht, speziell die Rinderzucht, die aber nur wenig produktiv ist, da diese hauptsächlich nur die Familienbedürfnisse erfüllen soll. Neben der Landwirtschaft gibt es noch Einnahmequellen durch Bergbau, insbesondere Chrom, Eisen, Kupfer und Blei (Keban Projekt 2007). 


\subsection{Produktionsstruktur}

\subsubsection{Ackerfrüchte}

\section{Getreide}

$81 \%$ der 16 Mio. Hektar Erntefläche in der Türkei werden für Getreide verwendet. Dies ermöglicht eine gesamte Produktion von Getreide in Höhe von 35,213 Mio. Tonnen. Der Weizenanteil an der gesamten Getreideproduktion beträgt ca. $62 \%$. Auch der Anteil der genutzten Erntefläche für Getreide ist für Weizen mit $65 \%$ am größten. Gefolgt wird Weizen von Gerste. Es entfallen 28\% der gesamten Erntefläche sowie der Produktionsmenge für Getreide auf Gerste. Wesentlich weniger als Weizen und Gerste werden Mais mit einer Produktionsmenge von 4,2 Mio. Tonnen auf einer Erntefläche von 528 Tsd. Hektar, Roggen mit einer Produktionsmenge von 370 Tsd. Tonnen auf einer Erntefläche von 131 Tsd. Hektar, Hafer mit einer Produktionsmenge von 215 Tsd. auf einer Erntefläche von 100 Tsd. Hektar und Reis mit einer Produktionsmenge von 900 Tsd. Tonnen auf einer Erntefläche von 99 Tsd. Hektar produziert.

Vergleicht man Produktionsmenge und Erntefläche der unterschiedlichen Getreidesorten miteinander, so fällt sofort auf, dass die Produktivität gemessen in Tonnen pro Hektar für Reis und Mais am höchsten ist (vgl. Turkish Statistical Institute 2011). Das gesamte Anbaugebiet von 13,6 Mio. Hektar entspricht mehr als 25 \% der EU-25 Anbaugebiete für Getreide. Dies macht die Türkei autark in der Produktion von Weizen, Gerste und Hafer (vgl. EU Kommission 2006).

\section{Hülsenfrüchte (getrocknet)}

1,1 Mio. Hektar der Erntefläche werden für Hülsenfrüchte genutzt. Das sind gerade einmal 7 \% der gesamten Erntefläche für Feldpflanzen. Die größten Ernteflächen werden mit 521 Tsd. Hektar für Kichererbsen und mit 379 Tsd. Hektar für Rote Linsen verwendet, die auch mit 506 Tsd. Tonnen für Kichererbsen und mit 395 Tsd. Tonnen für Rote Linsen die größten Produktionsmengen haben. Wie aus den Zahlen schon ersichtlich wird, ist die Produktivität von Roten Linsen mit 1,53 Tonnen/Hektar um 1/3 höher ist als die der Kichererbsen mit 1,2 Tonnen/Hektar. Darauf folgt die Produktion von Bohnen mit einer Produktionsmenge von 195 Tsd. Tonnen auf einer Erntefläche von 128 Tsd. Hektar und die der Dicken Bohnen mit einer Produktionsmenge von 21 Tsd. Tonnen auf einer Erntefläche von 10,5 Tsd. Hektar. Nennenswert ist noch die Produktion von grünen Linsen mit einer Produktionsmenge von 42 Tsd. Tonnen auf einer Erntefläche von 45 Tsd. Hektar. Die Produktivität ist hier also mit $1.060 \mathrm{~kg} / \mathrm{Hektar}$ am 
geringsten, während die Produktivität der Dicken Bohnen mit 2.300 kg/Hektar den Spitzenplatz unter den Hülsenfrüchten belegt (vgl. Turkish Statistical Institute 2013).

\section{Industriepflanzen und Kartoffeln}

Unter den Industriepflanzen sind vor allem Tabak, Zuckerrüben und Baumwolle zu nennen. Zuckerrüben werden in dieser Gruppe mit der höchsten Produktivität von 44,6 Tonnen/Hektar und der höchsten Produktionsmenge von 16,5 Mio. Tonnen angebaut, gefolgt von Baumwolle mit einer Produktivität von 4,32 Tonnen/Hektar und einer Produktionsmenge von 3,1 Mio. Tonnen. Tabak hat hier mit Abstand die geringste Produktivität mit nur 0,67 Tonnen/Hektar und einer Produktionsmenge von 98 Tsd. Tonnen. Die Kartoffel hat nach der Zuckerrübe in dieser Gruppe die größte Produktivität mit 27,7 Tonnen/Hektar und eine Produktionsmenge von 4,4 Mio. Tonnen (vgl. Turkish Statistical Institute 2013).

\subsubsection{Obst und Gemüse}

\section{Obst}

Um einen besseren Überblick zu bekommen, wird in diesem Abschnitt das Obst in sechs Gruppen eingeteilt, und zwar Beerenfrüchte, Zitrusfrüchte, Kernobst, Steinobst, Oliven und andere Nüsse sowie Tee.

Unter den Beerenfrüchten sind vor allem Weintrauben mit einer Produktionsmenge von 4 Mio. Tonnen und Feigen mit einer Produktionsmenge von 298 Tsd. Tonnen zu nennen. Die Produktionsmenge von Erdbeeren beträgt 136 Tsd. Tonnen. Für die Weintraubenproduktion werden rund 5 Mio. Weinreben benötigt und für die Feigenerzeugung 290 Tsd. Bäume. Des Weiteren werden noch 215 Tsd. Tonnen Bananen an 709 Tsd. Bäumen und 41,6 Tsd. Tonnen Kiwis an 729 Tsd. Bäumen produziert. Die Produktivität ist somit für Bananen am höchsten. Außerdem werden noch knapp 384 Tsd. Tonnen Granatäpfel und 75 Tsd. Tonnen Maulbeeren mit einer ähnlichen Produktivität produziert (vgl. Turkish Statistical Institute 2013).

Insgesamt werden 3,7 Mio. Tonnen Zitrusfrüchte an 36,4 Mio. Bäume produziert. 48\% dieser Produktionsmenge entfallen allein auf Orangen, für welche 13 Mio. Bäume benötigt werden. Die Produktionsmenge von Mandarinen und Zitronen ist mit 942 Tsd. und 726 Tsd. fast gleich, jedoch werden für die Zitronen nur 8 Mio. Bäume benötigt, das sind 35\% weniger als für die Produktion von Mandarinen verwendet werden. Zudem sind noch Grapefruits mit einer 
Produktionsmenge von knapp 180 Tsd. an 1 Mio. Bäumen zu nennen (vgl. Turkish Statistical Institute 2013).

In der Türkei werden knapp 3,6 Mio. Tonnen Kernobst produziert. Unterschiedliche Apfelsorten belegen dabei mit einer Gesamtproduktionsmenge von etwas über 3,1 Mio. Tonnen den Spitzenplatz. Nennenswert unter dem Kernobst ist noch die Produktion von 462 Tsd. Tonnen Birnen. Die Produktivität von Äpfeln ist um 40\% höher als die der Birnen (vgl. Turkish Statistical Institute 2013).

Alles in allem werden im Jahr 2,4 Mio. Tonnen Steinobst an 78,9 Mio. Bäumen produziert. Dabei sind vor allem Pfirsiche mit einer Produktionsmenge um 637,4 Tsd. mit 18,2 Mio. Bäumen und Aprikosen mit einer Produktionsmenge von 780 Tsd. Tonnen mit 17 Mio. Bäumen im Jahr 2013 zu erwähnen. Des Weiteren werden Pflaumen mit einer Produktionsmenge von 305 Tsd. Tonnen, Kirschen mit einer Produktionsmenge von 495 Tsd. Tonnen und Sauerkirschen mit einer Produktionsmenge von 180 Tsd. Tonnen hergestellt. Die Produktivitäten unterscheiden sich nicht wesentlich innerhalb in dieser Gruppe (vgl. Turkish Statistical Institute 2013).

In der Gruppe Oliven und andere Nüsse ist vor allem die hohe Produktionsmenge von Oliven zu nennen. Mit einer Produktionsmenge von 1,7 Mio. Tonnen im Jahr 2013 übertrifft die Erzeugung deutlich die aller anderen Nüsse oder Obstsorten dieser Gruppe. Haselnüsse, die als Exportschlager bekannt sind, wurden im Jahre 2013 mit einer Produktionsmenge von 549 Tsd. Tonnen an 355 Mio. Bäumen hergestellt. Außerdem ist noch die Produktion von Walnüssen mit einer Produktionsmenge von 212,1 Tsd. Tonnen und Pistazien mit einer Produktionsmenge von 88,6 Tsd. zu nennen, von denen ebenfalls große Mengen exportiert werden. Für Walnüsse werden dazu knapp 11,4 Mio. Bäume und für Pistazien 50,1 Mio. Bäume verwendet. Die Produktivität pro Baum ist bei Walnüssen(33 kg pro Baum) daher um ein vielfaches höher, als bei Pistazien(2 kg pro Baum). Des Weiteren werden noch Mandeln mit einer Produktionsmenge von 83 Tsd. Tonnen und Kastanien mit einer Produktionsmenge von 53 Tsd. Tonnen angebaut (vgl. Turkish Statistical Institute 2013).

In der Teeproduktion sind ungefähr 203 Tsd. Landwirte beschäftigt. Auf 76,6 Tsd. Hektar werden 1,2 Mio. Tonnen Teeblätter produziert. Dieses entspricht 202 Tsd. Tonnen getrocknetem Tee. 


\section{Gemüse}

Gemüse wird im Folgenden in fünf Gruppen eingeteilt, und zwar Fruchtgemüse, Wurzelgemüse, Hülsenfrüchte, Blattgemüse und anderes Gemüse. Spitzenreiter mit einer gesamten Produktionsmenge von etwas über 21 Mio. Tonnen ist das Fruchtgemüse. Dabei sind vor allem Tomaten mit einer Produktionsmenge von 11,8 Mio. Tonnen, Gurken mit einer Produktionsmenge von 1,8 Mio. Tonnen und Paprika mit einer Produktionsmenge von 2,2 Mio. Tonnen, Auberginen mit einer Produktionsmenge von 827 Tsd. Tonnen, Honigmelonen mit einer Produktionsmenge von 1,7 Mio. Tonnen und Wassermelonen mit einer Produktionsmenge von 3,9 Mio. Tonnen zu nennen. Platz zwei der Gruppe Gemüse belegt das Wurzelgemüse mit einer gesamten Produktionsmenge von fast 3 Mio. Tonnen. Der Anteil der getrockneten Zwiebeln macht dabei mit 1,9 Mio. Tonnen über die Hälfte der gesamten Produktion aus. Es folgt die Produktion des Blattgemüses mit einer Produktion von 1,5 Mio. Tonnen. Dabei ist vor allem die Herstellung von Weißkohl mit einer Produktionsmenge von 500 Tsd. Tonnen und Kopfsalat mit einer Produktionsmenge von 436 Tsd. Tonnen erwähnen. Ferner werden 774 Tsd. Tonnen Hülsenfrüchte produziert. Dabei macht der Anteil der grünen Bohnen mit 632 Tsd. Tonnen fast 3/4 der gesamten Produktion für Hülsenfrüchte aus. Die letzte Gruppe, anderes Gemüse, umfasst eine Produktionsmenge von 1,6 Mio. Tonnen. Dazu zählen vor allem Blumenkohl und Brokkoli (vgl. Turkish Statistical Institute 2013).

\subsubsection{Fleischwirtschaft}

\section{Vieh}

Die EU-Fördermaßnahmen zur Unterstützung des Anpassungsprozesses der Türkei im Agrarsektor sind für die Fleischwirtschaft am größten. Die Fleischwirtschaft in der Türkei trägt $3 \%$ zum Bruttoinlandsprodukt bei. $46 \%$ der Betriebe mit Tierproduktion haben 1 bis 4 Stück Vieh, $22 \%$ haben 5 bis 9 Stück Vieh, 57,7\% 10 bis 19 Stück Vieh, 1,5\% 20 bis $49 \%$ Stück Vieh und nur $0,08 \%$ haben 50 bis 99 Tiere oder mehr (vgl. Vural et al. 2007). Insgesamt werden 439 Tsd. Tonnen Fleisch produziert. Davon entfallen 340 Tsd. Tonnen auf die Rindfleischproduktion. Das sind über $77 \%$ der gesamten Produktionsmenge. Dabei entfallen jedoch mit 10,8 Mio. Tieren nur 24,8 \% des Viehbestandes auf Rinder. Beim Rinderbestand unterscheidet man zwischen dem domestizierten Rind mit einem Bestand von 14,90 Mio. Tieren, dem kultivierten Rind mit einem Bestand von 2 Mio. Tieren und einer Mischung dieser beiden mit einem Bestand von 3,5 Mio. Rindern. Daneben werden noch 716 Tsd. kultivierte und 776 
Tsd. domestizierte Kälber gehalten. Die Mischform beider macht hier sogar 1,1 Mio. Tiere aus (vgl. Turkish Statistical Institute 2013).

Der Bestand an Schafen liegt mit 32,19 Mio. Tieren bei 58,4 \% des Gesamtviehbestandes. Dabei macht der Anteil des Schaffleisches mit knapp 82 Tsd. Tonnen nur 18,7\% der gesamten Fleischproduktion aus. Der Bestand an Ziegen liegt bei 10,19 Mio. Tieren. Das sind 15,2 \% des gesamten Viehbestandes (vgl. Turkish Statistical Institute 2014). Der Bestand an Angoraziegen, die sehr wichtig für die Produktion von Wolle ist, macht knapp 210 Tsd. Tiere aus. Mit einer Produktionsmenge von $14 \mathrm{Tsd}$. Tonnen macht das Ziegenfleisch 3,2\% der gesamten Fleischproduktion aus. $97 \%$ der Fleischproduktion von Ziegen und Schafen werden mit der Produktion von Milch und Wolle kombiniert (vgl. Turkish Statistical Institute 2006). Der gesamte Viehbestand von Schafen und Ziegen wird von 570 Tsd. oft kleinen familiären Betrieben gehalten. So besitzen $18 \%$ der landwirtschaftlichen Betriebe mit Tierhaltung zwischen 1 und 19 Schafen oder Ziegen. $15 \%$ besitzen zwischen 20 und 49 Tiere, 8,3\% zwischen 50 und 99 Tiere und knapp $5 \%$ der Betriebe 100 Tiere oder mehr (Vural et al. 2007).

\section{Geflügel}

Der Bestand an Geflügel konzentriert sich hauptsächlich auf Hühner für die Eierproduktion und Hähnchen für die Fleischproduktion. Insgesamt liegt der Anteil der Hähnchen bei 81,9 \% und der Hühner bei 16,8 \% des gesamten Geflügelbestands. Zusammen sind das über 344 Mio. Tiere. Folglich ist der Anteil von Hähnchenfleisch an der gesamten Produktionsmenge von Geflügelfleisch mit 98,2\% auch sehr hoch. Von 1.293 Tsd. Tonnen Geflügelfleisch entfallen somit 1.277 Tsd. Tonnen auf Hähnchen. Mit dem Bestand von 59 Mio. Hühnern werden pro Jahr 733 Tsd. Tonnen Eier produziert. 1 Tonne macht dabei 16 Tsd. Eier aus. Des Weiteren werden noch 3 Mio. Puten gehalten, welche 0,9\% des gesamten Geflügelbestandes ausmachen. Auf Gänse, Enten und Puten entfallen zusammen 1,8\% der Produktion von Geflügelfleisch. Für Putenfleisch sind das 30 Tsd. Tonnen pro Jahr (vgl. Turkish Statistical Institute 2009).

\subsubsection{Milchproduktion}

Insgesamt werden knapp 12 Mio. Tonnen Milch produziert. Dabei fallen mit 10,9 Mio. Tonnen $91 \%$ auf Rinder, mit 794 Tsd. Tonnen 6,5\% auf Schafe, mit 25 Tsd. Tonnen 2,1\% auf Ziegen und $0,3 \%$ der Milchproduktion auf Büffel (vgl. Turkish Statistical Institute 2006). Die Milchleistung in der Türkei hat sich in den letzten Jahren kaum verbessert und lag im Jahre 2004 immer noch unter $2000 \mathrm{~kg} / \mathrm{Kuh} / \mathrm{Jahr}$. Im Vergleich dazu ist die Milchleistung der EU-15 mit über 
$6000 \mathrm{~kg} / \mathrm{Kuh} / \mathrm{Jahr}$ um ein vielfaches höher. Die Gründe hierfür werden in der geringen Professionalität und den geringen Betriebsgrößen in der Milchproduktion gesehen. So werden 5 Mio. Milchkühe auf 2,5 Mio. landwirtschaftlichen Betrieben gehalten und die Milch wird oft direkt auf den kleinen Betrieben konsumiert. Auch die berufspraktische Ausbildung der Landwirte fehlt zu großen Teilen. Ein weiteres Problem stellen die hohen Zölle dar, die das Preisniveau für Getreide, welches zur Fütterung verwendet wird, künstlich auf einem hohen Niveau halten. Auch die Qualität der Rohmilch ist oft nicht ausreichend. Dieses liegt daran, dass ein Großteil der Milch über Straßenverkäufe oder über sogenannte Mandıras abgesetzt werden. Das sind kleine Milchverarbeiter mit weniger als zehn Mitarbeitern. Diese werden steuerlich nicht erfasst und daher auch nicht auf die Einhaltung der üblichen lebensmittelrechtlichen Bestimmungen hin kontrolliert (vgl. Grethe 2005).

\section{Abbildung 1: Milchleistung in der Türkei und der EU 1986 - 2004}

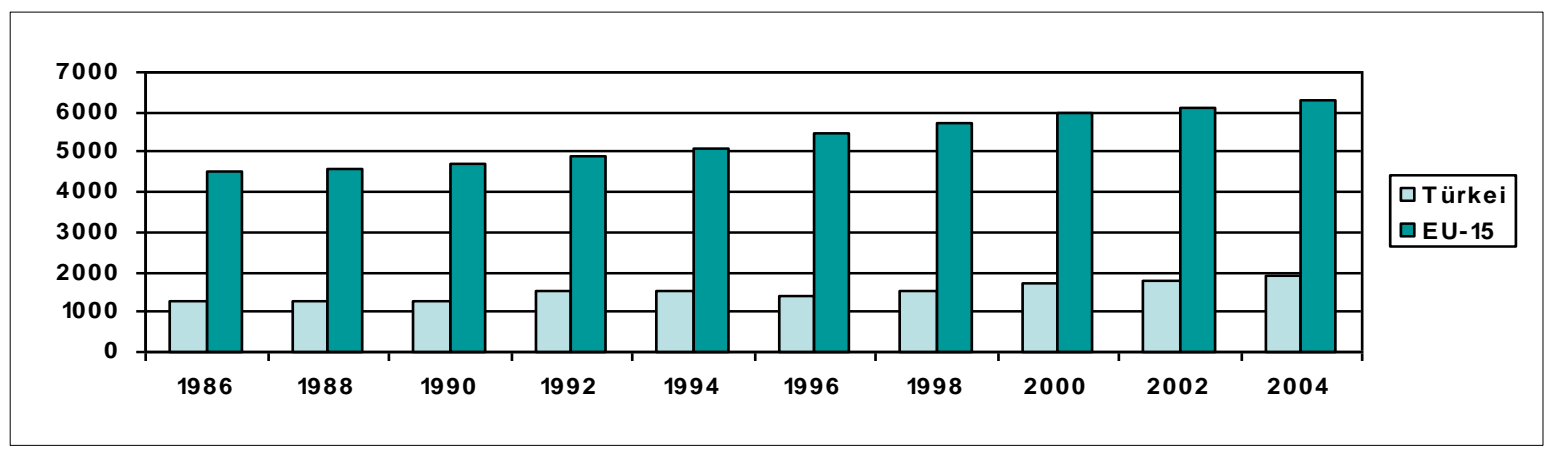

Quelle: Grethe 2005

\subsection{Handelsbeziehungen zwischen der Türkei und der EU}

Im Jahre 1995 haben die Türkei und die EU eine Zollunion gebildet. Die EU ist mit Abstand der größte Wirtschaftspartner der Türkei mit $37,7 \%$ des Gesamthandels und $71,3 \%$ der ausländischen Direktinvestitionen in der EU, weil die Türkei der sechstgrößte Handelspartner der EU (IPA II 2014).

Wird der gesamte Außenhandel betrachtet, so weist die Türkei einen negativen Saldo der Handelsbilanz in Höhe von -37,4 Mrd. € aus. Somit ist die Türkei ein Nettoimporteur, der Waren im Wert von 78,2 Mrd. exportiert und Waren im Wert von 115,6 Mrd. importiert. Wird der Handel von Agrarprodukten jedoch isoliert betrachtet, sieht die Lage anders aus. Hier weist die Türkei eine positive Handelsbilanz von 2,4 Mrd. € aus. 
Tabelle 1: Türkische Exporte und Importe (2009)

\begin{tabular}{|l|l|l|l|}
\hline Handel & Exporte & Importe & Handelsbilanz \\
\hline insgesamt & 78,2 Mrd. € & 115,6 Mrd. € & $-37,4$ Mrd. € \\
\hline Wert Agrarprodukte & 6,4 Mrd. € & 4 Mrd. € & $+2,4$ Mrd. € \\
\hline $\begin{array}{l}\text { Anteil Agrarprodukte } \\
\text { (in \%) }\end{array}$ & $9,4 \%$ & $5,9 \%$ & \\
\cline { 1 - 3 } & & &
\end{tabular}

Quelle: Vgl. Bundesforschungsinstitut für ländliche Räume Land und Fischerei 2009

Auch in den letzten Jahren wies die Türkei eine positive Handelsbilanz bei den Agrarprodukten aus. Allerdings haben sowohl Importe als auch Exporte in den letzten Jahren an Bedeutung zugenommen. Vergleicht man das Jahr 1999 mit dem Jahr 2006, so sind die Agrarimporte um $60 \%$ und die Agrarimporte um $63 \%$ gestiegen.

Abbildung 2: Agrarexporte und -importe zwischen 1999 und 2006 (in Mrd. €)

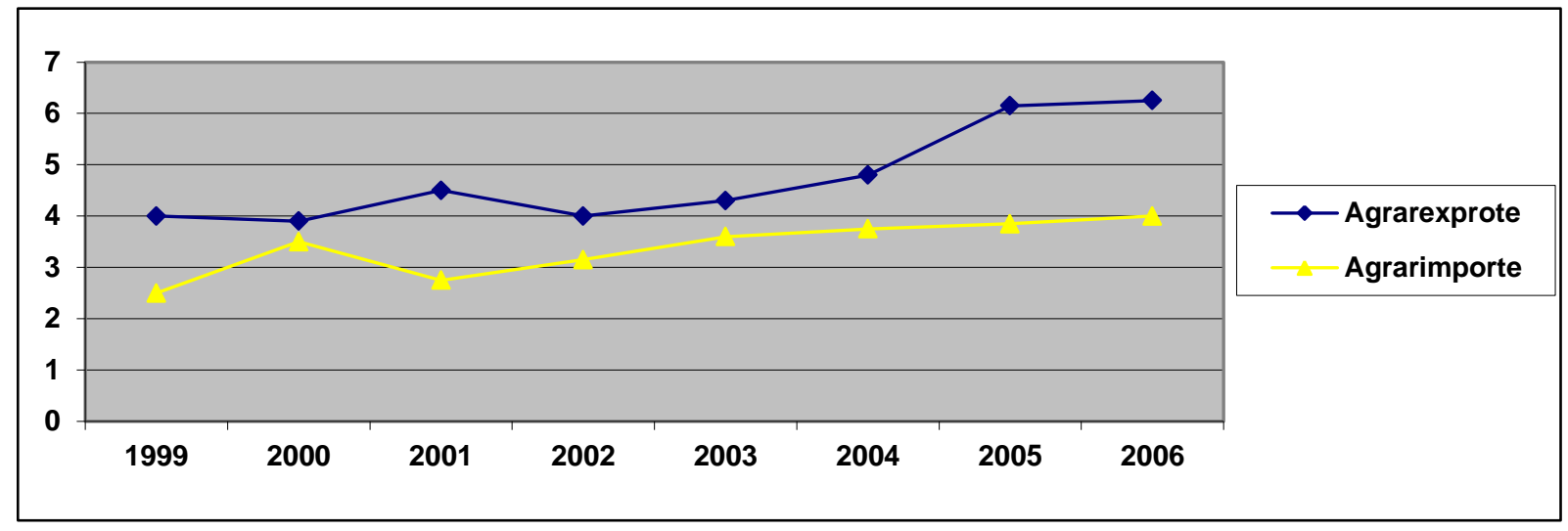

Quelle: Vgl. Bundesforschungsinstitut für ländliche Räume Land und Fischerei 2009

Für die Agrarexporte und Agrarimporte gibt es jeweils fünf Länder, die zusammen jeweils über $50 \%$ des wertmäßigen Handels ausmachen. Im Jahre 2006 war die EU-25 jeweils auf beiden Seiten der mit Abstand wichtigste Handelspartner. So konnte die Türkei 45\% ihrer Agrarexporte dorthin absetzen und $30 \%$ ihrer Agrarimporte von dort beziehen. Ein weiterer wichtiger Handelspartner auf der Exportseite ist der Irak; auf der Importseite sind dies die USA (vgl. Bundesforschungsinstitut für ländliche Räume, Land und Fischerei 2009).

Für die Agrarexporte und Agrarimporte gibt es jeweils fünf Länder, die zusammen über 50 \% des wertmäßigen Handels ausmachen. Im Jahr 2006 war die EU-25 jeweils auf beiden Seiten der mit Abstand wichtigste Handelspartner. So konnte die Türkei $45 \%$ ihrer Agrarexporte dorthin 
absetzen und 30\% ihrer Agrarimporte von dort beziehen. Ein weiterer wichtiger Handelspartner auf der Exportseite ist der Irak und auf der Importseite die USA.

\section{Abbildung 3: Handelspartner der Türkei im Jahr 2006}
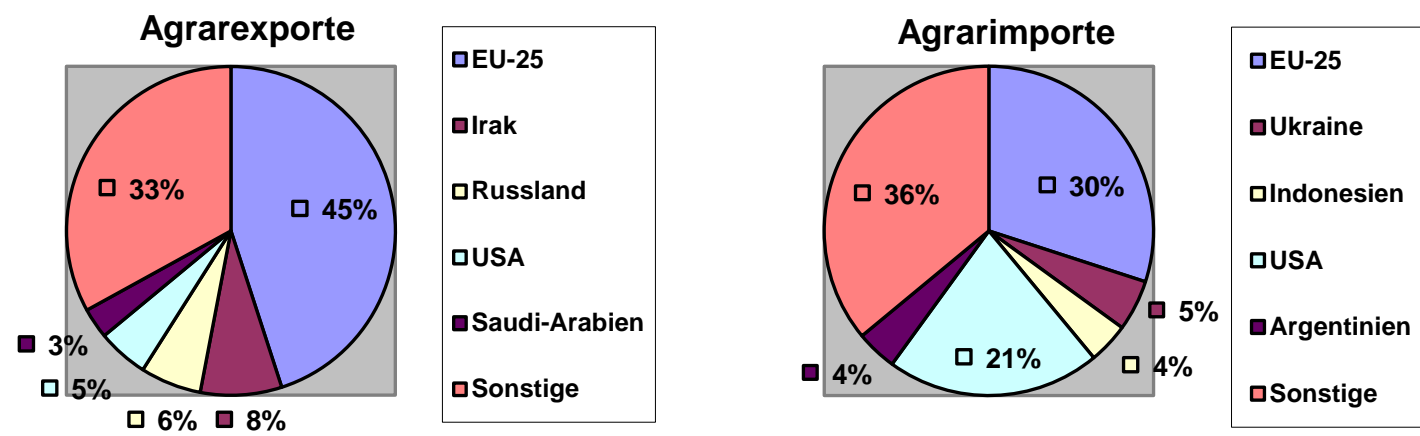

Quelle: Vgl. Bundesforschungsinstitut für ländliche Räume, Land und Fischerei 2009

Die türkischen Agrarexporte in die EU konzentrieren sich auf nur wenige Produkte. So werden hauptsächlich Obst, Gemüse und Nüsse mit einem Wert von ca. 1.600 Mio. $€$ in die EU exportiert. Seit Ende der achtziger Jahre sind die Hauptexportprodukte der Türkei Obst, Gemüse und Tabak, welche zusammen über $65 \%$ der gesamten landwirtschaftlichen Exporte ausmachen. Die Exporte in die EU sehen fast ähnlich aus. Im Unterschied zu den gesamten Exporten wird in die EU weniger Tabak exportiert. Obst und Gemüse machen hier alleine schon 70\% aller landwirtschaftlichen Exporte aus (vgl. Grethe 2003). Das Hauptimportprodukt aus der EU ist Getreide mit einem Wert von 170 Mio. $€$ für das Jahr 2009. Die türkischen Exporte blieben zwischen den Jahren 2007 und 2009 annähernd konstant. Allerdings konnte der Export von Getreide in diesem Zeitraum um $85 \%$ gesteigert werden. Das Gleiche gilt für den Import aus EU-Ländern. Auch hier konnte der Import von Getreide gesteigert werden, nämlich um 35 \%. Milchprodukte, Eier und Honig konnten im Vergleich zum Jahr 2007 im Jahr 2009 um 55 \% stärker abgesetzt werden. Im Jahre 2009 hatte die Türkei im Agrarsektor einen Handelsüberschuss mit der EU-27 von 1,5 Milliarden Euro. (vgl. EU Kommission 2010) 
Tabelle 2: Türkische Exporte in die EU

\begin{tabular}{|l|c|c|c|c|}
\hline $\begin{array}{c}\text { Türkische Exporte } \\
\text { in die EU }\end{array}$ & $\mathbf{2 0 0 7}$ & $\mathbf{2 0 0 8}$ & $\mathbf{2 0 0 9}$ & $\begin{array}{c}\text { Veränderung } \\
\mathbf{2 0 0 7}-\mathbf{2 0 0 9} \\
\text { (in \%) }\end{array}$ \\
\hline Früchte, Nüsse & 1183 Mio. $€$ & 1224 Mio. $€$ & 1158 Mio. $€$ & $-2,2$ \\
\hline Gemüse & 319,2 Mio $€$ & 306,2 Mio. $€$ & 311 Mio. $€$ & $-2,6$ \\
\hline Getreide & 16,7 Mio. $€$ & 21,9 Mio. $€$ & 31 Mio. $€$ & 85 \\
\hline Wein und Essig & 5,6 Mio. $€$ & 2,4 Mio. $€$ & 3 Mio. $€$ & -47 \\
\hline Milchprodukte, Eier & 1,4 Mio. $€$ & 1,6 Mio. $€$ & 2 Mio. $€$ & 42 \\
und Honig & & & & \\
\hline
\end{tabular}

Quelle: EU-Kommission 2010

Tabelle 3: Türkische Importe aus der EU

\begin{tabular}{|l|c|c|c|c|}
\hline \multicolumn{1}{|c|}{$\begin{array}{c}\text { Türkische Importe } \\
\text { aus der EU }\end{array}$} & $\mathbf{2 0 0 7}$ & $\mathbf{2 0 0 8}$ & $\mathbf{2 0 0 9}$ & $\begin{array}{c}\text { Veränderung } \\
\mathbf{2 0 0 7 - 2 0 0 9} \\
\text { (in \%) }\end{array}$ \\
\hline Getreide & 125,4 Mio. $€$ & 288,9 Mio. $€$ & 170 Mio. $€$ & 35 \\
\hline Früchte, Nüsse & 26,9 Mio. $€$ & 22,6 Mio. $€$ & 26 Mio. $€$ & $-3,5$ \\
\hline Milchprodukte, Eier & 24,4 Mio. $€$ & 37,8 Mio. $€$ & 30 Mio. $€$ & 55 \\
\hline und Honig & 8,3 Mio. $€$ & 11 Mio. $€$ & 6 Mio. $€$ & $-27,7$ \\
\hline Zucker & 16,1 Mio. $€$ & 13,9 Mio. $€$ & 13 Mio. $€$ & -19 \\
\hline Gemüse & & & & \\
\hline
\end{tabular}

Quelle: EU-Kommission 2010 


\section{Qualitätssicherung in der türkischen Agrar- und Ernährungswirtschaft}

\subsection{Ist-Zustand der türkischen Qualitätssicherung nach nationalen gesetzlichen Vorgaben}

Mit der zunehmenden Internationalisierung der Märkte ergeben sich für die türkische Agrar- und Ernährungswirtschaft neue Herausforderungen. Seit dem Jahre 2005 beschäftigt sich die Türkei mit den 35 Beitrittskapiteln im Rahmen der Beitrittsverhandlungen der Europäischen Union (EU). Im Jahre 2010 wurden Verhandlungen über Kapitel 12 Lebensmittelsicherheit, Veterinärpolitik und Pflanzenschutz aufgenommen. Der jüngste jährliche Fortschrittsbericht der Europäischen Union zeigt, welche bedeutsamen Fortschritte die türkische Gesetzgebung und Regulierung für Lebensmittelqualität und -sicherheit unter erheblichen Anstrengungen, erzielt hat (Europäische Kommission 2013a).

In der Türkei setzt das Ministerium für Ernährung, Landwirtschaft und Viehzucht (MfELV) die staatlichen Standards für Lebensmittelsicherheit, Tier- und Pflanzengesundheit fest. (Türkische Lebensmittel-Verordnung vom Ministerium für Ernährung, Landwirtschaft und Viehzucht in Ankara 2011) Das Ministerium besteht aus 13 verschiedenen Abteilungen, welche unterschiedliche Aufgaben zu bewältigen haben, wie unter anderem die Entwicklung der pflanzlichen und tierischen Erzeugung, die Aquakultur, Tier- und Pflanzenschutz und Quarantäne, Lebensmittel- und Futtermittelregistrierung, die Prüfung und Zulassung von Lizenzen, Pflanzenschutzmitteln und der Veterinärmedizin, Regelungen in Bezug auf Fischerei und Jagd, Gesundheit der Aquakultur, Umweltschutz und Regelungen für die Katastrophenhilfe, Verwaltung zum Zwecke einer effektiven Agrarförderung und Regulierung der Agrarmärkte, EUund Außenbeziehungen und letztendlich die landwirtschaftliche Forschung und Agrarpolitik (ENVI Delegation 2011).

Die Abteilung Generaldirektion der Lebensmittel und Kontrolle ist für die Pflanzen- und Tierschutzkontrollen, die Grenzkontrollen der Pflanzen und Tierprodukte, Lebensmittel- und Futtermittelunternehmen sowie Laborkontrollen, Risikobewertung und Quarantäne verantwortlich. Folglich ist diese Einheit im Wesentlichen für die Fragen der Lebensmittelsicherheit zuständig.

Im Jahre 2010 wurde von dem MfELV das Gesetz Nr. 5996 für "Veterinärdienste, Pflanzenschutz, Lebensmittel und Futtermittelrecht" erlassen, nachdem durch mehrmalige Änderungen und Verbesserungen das Gesetz an die Verordnung (EG) Nr. 178/2002 angepasst 
wurde (Amtsblatt 2010, Nr. 27610). Dieses Gesetz beinhaltet die Verordnung des türkischen Lebensmittelkodexes mit den Aufgabengebieten der Lebensmittelzusatzstoffe, Aromastoffe, Verunreinigungen durch Toxine, Metalle und Fremdstoffe, Pestizidrückstände, Menge der Rückstände von Tierarzneimitteln, Lebensmittelhygiene, erforderliche Eigenschaften der Lebensmittelhersteller, Verpackung, Kennzeichnung und Markierung, Lieferung und Lagerung von Lebensmitteln, Probenahme und Analysemethoden. Diese Verordnung zum Lebensmittelkodex kann bei Erfordernis vom Ausschuss aktualisiert, verbessert und ergänzt werden. Beispielsweise fand im Jahre 2011 eine Revision der 2002/72/EG-Richtlinie über Kunststoffe und Gegenstände, die in Berührung mit Lebensmitteln kommen (EU-Verordnung Nr. 10/2011) statt, woraufhin diese der türkischen Institution für EU- und Außenbeziehungen als Vorlage empfohlen wurde. Diese Verordnung wurde von der türkischen Institution für EU- und Außenbeziehungen an die zuständige Abteilung weitergeleitet, woraufhin der türkische Lebensmittelkodex am 17. Juli 2013 an die Verordnung angepasst und aktualisiert wurde (Amtsblatt 2013, Nr. 2810).

Das Hazard Analysis and Critical Control Point (HACCP)-Konzept wurde erstmals in der Verordnung im türkischen Lebensmittelkodex eingeführt. Ab dem Jahre 1997 haben viele Lebensmittelhersteller und Lebensmitteleinzelhändler das HACCP-Konzept implementiert, insbesondere Lebensmittelexporteure, in die EU, da diese im Rahmen der Zollunion dazu verpflichtet sind, die Richtlinien des HACCP-Konzepts einzuhalten.

Nach einer bestimmten Periode zur Anpassung an die neuen Richtlinien des HACCP wurden in allen Lebensmittelbereichen obligatorische Prüfungen und offizielle Inspektionen im Rahmen der Überprüfung der Einhaltung der HACCP-Richtlinien durchgeführt. Am 31. März 2008 wurde eine Verordnung über die Überwachung und Kontrolle der Lebensmittelsicherheit und Lebensmittelqualität in Kraft gesetzt, wonach alle Lebensmittelhersteller dazu verpflichtet sind, das HACCP-Konzept anzuwenden (Koc 2011).

Die amtlichen Laboratorien sind in drei Bereiche unterteilt: Laboratorien für Veterinärkontrolle und Forschungsinstitut, Provinzlaboratorien und Laboratorien für Pflanzengesundheit, welche die Überwachung der Einhaltung der Probeannahmen, Inspektionstätigkeiten, die Überprüfung zulässiger Grenzwerte, die Identifizierung von Problemen in der Lebensmittelkette sowie analytische Untersuchungen durchführen. Seit dem Jahre 2014 gibt es 39 Provinzlaboratorien, ein zentrales Forschungsinstitut für Lebens- und Futtermittelkontrolle, 90 private Laboratorien, von denen 23 akkreditiert sind, während nur ein öffentliches Labor von Turkak akkreditiert 
wurde (MfELV 2014). Die Türkische Akkreditierungsagentur (TURKAK) ist eine Überwachungsbehörde im Bereich der Good Laboratory Practice und ist Mitglied der Europäischen Kooperation für die Akkreditierung. TURKAK wirkt als Hauptorganisation für Konformitätsbewertung und bezweckt die Bewerkstelligung der Zugänglichkeit von Standards und des Qualitätsaudits weltweit sowie die Information und Beratung der Privatwirtschaft und der Industrieregionen. Im Jahre 2011 ist die Zahl der Akkreditierungen durch TURKAK auf 647 gestiegen (FAO 2012).

Die Türkisch Standards Institution (TSE) spielt eine sehr wichtige Rolle in Bezug auf die Qualität sowie auch die Sicherheit von Lebensmitteln auf nationaler und internationaler Ebene. TSE übernimmt die wissenschaftliche Kooperation zwischen Forschungsinstitut, Ministerium und Privatwirtschaft. Die Dienstleistungsbereiche sind folgende: Zertifizierung von Managementsystemen, Personalzertifizierung, Dokumentierung und Zertifizierung von Produkten und Standorten, Messtechnik und Kalibrierung, Standardzubereitung und letztlich der Verbraucherschutz. TSE wurde von TURKAK akkreditiert.

TSE verfolgt die internationalen Entwicklungstendenzen im Bereich der Standards, um anschließend die Ergebnisse den zuständigen Ministerien zu präsentieren. Im Jahre 2012 wurde TSE vollständiges Mitglied des Europäischen Komitees für Normung (CEN) und wurde somit vollständig in das europäische Normungssystem integriert. TSE ist verantwortlich für die Erarbeitung der Normen einschließlich als „Turkish standard“, um den Unternehmen einen entsprechend Service zu bieten. Seit dem Jahre 2011 ist der TSE für die Umsetzung der HelalZertifizierung sowie auch der ISO-Normen berechtigt. Die nachkommenden Prüfungen von Zertifizierungssystemen werden durch die privaten Auditoren übernommen (Ministry for EU Affairs 2013).

Das europäische Schnellwarnsystem für Lebensmittel und Futtermittel (RASFF) ist ein Schnellwarnsystem der Europäischen Kommission. Es besteht aus klar festgelegten Kontaktstellen in der Europäischen Behörde für Lebensmittelsicherheit (EFSA), sowie auf nationaler Ebene in den Mitgliedstaaten. Grundlage hierfür ist die Lebensmittel Gesetzgebung des Europäischen Parlaments 28. Januar 2002. Die Türkei ist derzeit nicht Mitglied des RASFFSystem. Über das RASFF-System werden von nationalen Koordinationsstellen (z.B. in Deutschland Bundesamt für Verbraucherschutz und Lebensmittelsicherheit) Warnungen von auffälligen Lebensmitteln und behördlich angeordnete Produktrückrufe von Lebens- und Futtermitteln dokumentiert und an die entsprechenden Stellen der Mitgliedstaaten der EU 
weitergeleitet, um eventuell Informationen und Warnungen an die Öffentlichkeit zu verbreiten. Die Benachrichtigungen werden in Informationen, Warnungen und Grenzzurückweisungen klassifiziert. Seit Bestehen des Systems ist die Anzahl der Warnungen stetig gestiegen. Etwa die Hälfte der Meldungen (52\%) betraf Erzeugnisse aus Drittländern. Die Türkei bekam im Jahre 2011 (319), 2012 (309) und 2013 (226) Meldungen, davon betrafen für das letztgenannte Jahr die meisten Aflatoxine in Nüssen, Nussprodukten und Saatgut (61 Meldungen) sowie Aflatoxine in Obst und Gemüse (39 Meldungen). Das Lebensmittel- und Veterinäramt berichtete in den letzten vier Jahren über eine hohe Anzahl von Zwischenfällen in Zusammenhang mit Produkten aus der Türkei, insbesondere in Bezug auf Mykotoxine und Pestizidrückstände angesichts des hohen Volumens im Obst- und Gemüseexport (RASFF 2013).

In den Fortschrittsberichten der EU Kommission aus den vergangenen drei Jahren wird immer wieder darauf aufmerksam gemacht, dass unter anderem im Bereich des Veterinärwesens in der Türkei substantielle Aufgaben anstehen, um den EU Standards gerecht zu werden, da es z. B. immer wieder zum Auftreten der Maul und Klauenseuche gekommen ist. Die EU Anforderungen erfassen im Wesentlichen folgende Punkte: Bekämpfung gegen Tierkrankheiten und Infektionen, Tiergesundheit, Tierschutz, Kennzeichnung und Registrierung von Tieren und damit Kontrolle und Rückverfolgbarkeit von Krankheiten, Kontrolle von Futtermittelhygiene und Zoonose. Die oben genannten Aspekte sind alle Aufgaben der Türkei im Bereich der Veterinärpolitik. (EU Kommission 2011- 2014 Turkey Progress Report; zuletzt: 8. Oktober 2014).

\subsection{Ist-Zustand in Qualitätssicherung in der Türkei nach internationalen Standards}

2008 gab es in der Türkei 13.826 Betriebe, die internationale Qualitätsstandards eingeführt hatten. Damit liegt die Türkei nach Ungarn auf dem zweiten Platz der CEEC-Länder. Hauptsächlich wird mit dem ISO 9001 und dem GlobalGAP-Standard gearbeitet. Diesen Zertifizierungssystemen sind 12.350 bzw. 1.232 Betriebe angeschlossen. Des Weiteren gibt es noch - wenn auch in weitaus geringerer Zahl - Betriebe mit Zertifizierungen nach BRC-, IFSund Demeter-Standards, die 89, 54 bzw. 101 Mitglieder haben. Unter den CEEC-Ländern ist die Türkei insoweit führend. So entfallen auf die Türkei über die Hälfte der GlobalGAPZertifizierungen und fast $70 \%$ der Demeter-Zertifizierungen. Dagegen werden die von der Europäischen Union vorgelegten Standards zur Sicherung von Produkten mit qualifizierten geographischen Herkunftsangaben bislang nicht genutzt (PDO/PDI). (vgl. Gawron und Theuvsen 2009). 
Im ISO Survey des Jahres 2013 werden 733 ISO 22000 zertifizierte Unternehmen in der Türkei genannt; das Land belegt somit weltweit den siebten Platz. Auf Platz eins steht China mit 9.406 zertifizierten Unternehmen, gefolgt von Griechenland mit 1.720 Unternehmen (offizielle ISOSeite 2014)

Tabelle 4: Anzahl der Zertifizierungen in Mittel- und Osteuropa

\begin{tabular}{|c|c|c|c|c|c|c|c|}
\hline & $\begin{array}{l}\text { ISO } 9001 \text { (all } \\
\text { industries) }\end{array}$ & $\begin{array}{l}\text { Global- } \\
\text { GAP }\end{array}$ & BRC & IFS & $Q \& S$ & $\begin{array}{c}\text { PDO/ } \\
\text { PGI }\end{array}$ & Demeter \\
\hline Albania & 28 & - & - & - & - & - & - \\
\hline Armenia & 34 & - & - & - & - & - & - \\
\hline $\begin{array}{l}\text { Bosnia and } \\
\text { Herzegovina }\end{array}$ & 242 & 1 & - & - & - & - & - \\
\hline Bulgaria & 3,097 & & 3 & 17 & 2 & - & - \\
\hline Croatia & 1,676 & 67 & 4 & 8 & & - & 1 \\
\hline $\begin{array}{l}\text { Czech } \\
\text { Republic }\end{array}$ & 12,811 & 12 & 78 & 82 & 6 & 12 & 1 \\
\hline Estonia & 577 & - & 3 & 2 & - & - & - \\
\hline Georgia & 52 & - & - & - & - & - & - \\
\hline Hungary & 15,008 & 641 & 50 & 220 & 62 & 1 & 4 \\
\hline Latvia & 625 & - & 1 & 2 & - & - & - \\
\hline Lithuania & 697 & 1 & 9 & 9 & - & - & - \\
\hline Macedonia & 217 & 4 & 2 & 1 & - & - & - \\
\hline Moldova & 41 & 1 & - & 3 & - & - & - \\
\hline Poland & 8,115 & 392 & 134 & 237 & 199 & 2 & 5 \\
\hline Romania & 9,426 & 24 & 3 & 30 & - & - & 1 \\
\hline Russia & 6,398 & - & 3 & 5 & - & - & - \\
\hline Serbia & 1,551 & - & 4 & - & - & - & - \\
\hline Slovakia & 2,195 & 12 & 11 & 21 & 8 & 1 & 1 \\
\hline Slovenia & 2,182 & 7 & 3 & 17 & - & 1 & 22 \\
\hline Turkey & 12,350 & 1,232 & 89 & 54 & - & - & 101 \\
\hline Ukraine & 1,808 & - & 1 & 1 & - & - & - \\
\hline CEEC Total & 79,130 & 2,394 & 398 & 704 & 277 & 17 & 146 \\
\hline Germany & 46,458 & 7,189 & 267 & 2,799 & 109,405 & 69 & 1,621 \\
\hline Europe Total & 415,169 & 56,504 & 6,000 & 8,045 & 117,369 & 779 & 3,219 \\
\hline World Total & 897,866 & 71,125 & 7,286 & 8,543 & 117,369 & 780 & 7,678 \\
\hline
\end{tabular}

Quelle: Gawron/Theuvsen 2009 


\subsection{Zertifizierungssysteme als Möglichkeit der Qualitätssicherung}

Die nahezu flächendeckende Einführung von Zertifizierungssystemen ist eine der hervorstechenden Entwicklungen in der Agrar- und Ernährungswirtschaft in den vergangenen Jahren gewesen. Im Zuge dieser Entwicklung haben verschiedene Standards Anwendung gefunden (vgl. u.a. Hatanaka/Bain/Busch 2005).

ISO 9001 ist ein "Business to Business"-Standard und fokussiert somit die Beziehungen zwischen verschiedenen Unternehmen der Food Supply Chain, wird jedoch nicht an Konsumenten kommuniziert. ISO 9001 bildet den Rahmen für die Ausgestaltung des Qualitätsmanagementsystems von Unternehmen. Dieser branchenneutrale Standard ist weltweit mit 900000 Zertifizierungen in den verschiedensten Branchen führend. Jedoch enthält er keine sektorspezifischen Aspekte wie z.B. Regelungen zum Hygienemanagement oder zu sensorischen Tests.

GlobalGAP ist wie die ISO 9001 ein "Business to Business"-Standard und bezieht sich somit ebenfalls auf die Beziehung von zwei oder mehreren Unternehmen untereinander. Dieses Zertifizierungssystem soll vor allem eine einwandfreie Produktion sicherstellen und wird ausschließlich in der Landwirtschaft, nicht jedoch z.B. in der Verarbeitung eingesetzt. Die durch GlobalGAP definierten Mindeststandards sollen auch die natürlichen Ressourcen, die Umwelt und die Gesundheit der Mitarbeiter sichern. Im Zuge der Implementierung von GlobalGAP werden Systeme der Rückverfolgbarkeit für die Produktion und weitere Systeme zur Sicherstellung der Erfüllung anderer Kriterien installiert. Nach diesem Standard sind weltweit 71.125 Unternehmen zertifiziert.

Der Zertifizierungsstandard des British Retailer Consortium (BRC) wurde ursprünglich von Einzelhändlern in Großbritannien geschaffen, um die Hygiene und Qualität der Zulieferer zu überprüfen. Dieser Standard lehnt sich an ISO 9000 und HACCP an, umfasst aber zusätzlich Prozessabläufe, Produktprüfung, Personalhygiene und den baulichen Zustand der Gebäude. BRC ist ein internationaler "Business to Business" -Standard und umfasst 6.000 Zertifizierungen in Europa und 7.300 Zertifizierungen weltweit.

Der International Food Standard (IFS; jetzt: International Featured Standard Food) wurde von deutschen Einzelhändlern entwickelt, um die Anzahl von Audits und somit die Kosten der Zertifizierung für die Zulieferer zu reduzieren. Der Fokus dieses Standards ist auf das Qualitätsmanagement der verarbeitenden Unternehmen gerichtet und zeichnet sich durch eine 
hohe Transparenz der Lieferketten aus. So soll eine gemeinsame Beurteilungsgrundlage für alle Eigenmarken des Handels geschaffen werden, zum Beispiel durch eine einheitliche Formulierung und Durchführung von Audits. Auch dieser Standard lehnt sich an die ISO 9000 an, umfasst jedoch noch Kriterien für die Prozesse des Ressourcenmanagements, die Herstellung sowie eine kontinuierliche Verbesserung durch Messungen und Analysen. Dieser internationale, inzwischen auch durch französische und italienische Lebensmittel-einzelhandelsunternehmen verwendete Standard hat 8.500 Zertifizierungen in Europa.

Der deutsche Q\&S-Standard ist ein Zertifizierungssystem, das Elemente von "Business to Business" - und "Business to Consumer" -Standard vereint. Das heißt, dass sich der Q\&SStandard auf das Qualitätsmanagement fokussiert und die komplette Supply Chain von der landwirtschaftlichen Produktion bis hin zum Konsumenten absichert. Dieses soll über eine regelmäßige Überprüfung der Betriebe auf allen Stufen erfolgen. Die Kriterien hierfür übersteigen dabei in Einzelfällen sogar die gesetzlichen Anforderungen. Ziel der Q\&S-Standards ist vor allem die Stärkung des gegenseitigen Vertrauens aller Wirtschaftspartner. Die meisten nach diesem Standard zertifizierten Unternehmen sind in Deutschland beheimatet (vgl. Gawron/Theuvsen 2009; Theuvsen 2006).

Auf Initiative der Europäischen Union wurde ein Gesetz zum Schutz von Agrarerzeugnissen und Lebensmitteln verabschiedet. Es geht hier um die Differenzierung und Sicherung von Produkten nach ihren speziellen traditionellen oder geographischen Aspekten. Nach der geschützten Ursprungsbezeichnung (PDO) soll die Herstellung und Verarbeitung eines Erzeugnisses in einem bestimmten geographischen Gebiet nach einem festgelegten Verfahren erfolgen. Die geschützte geographische Angabe (PDI) verweist auf die Verbindung von Herkunftsgebiet und mindestens einer Produktionsstufe der Erzeugung. Bei der garantierten traditionellen Spezialität (TSG) gilt es, die traditionelle Zusammensetzung oder die traditionelle Herstellung bzw. Weiterverarbeitungsverfahren hervorzuheben und zu sichern (vgl. Krieger 2007).

Demeter ist ein Beispiel für einen "Business to Consumer"-Standard und konzentriert sich ausschließlich auf den Produktionsprozess von ökologischen Produkten. Hauptziel ist die Produktdifferenzierung, wie schon bei den PDO/PGI/TSG Standards. Der Endkunde wird über ein Produktlabel angesprochen (vgl. Gawron/Theuvsen 2009). Neben Demeter gibt es weitere Label aus dem Bereich des ökologischen Landbaus. 


\subsection{Systematisierungen von Zertifizierungssystemen}

Zertifizierungssysteme können unter Rückgriff auf verschiedene Kriterien systematisiert werden. Diese sind: Träger, Adressaten, Fokus, Ziele, geographische Ausdehnung, Teilnehmerzahl und Reichweite (Theuvsen/Gawron 2007). Bezüglich des Trägers unterscheidet man zwischen staatlichen und privaten Standards. Die privaten Standards werden von nicht-staatlichen Organisationen getragen, wie z. B. Abnehmern, Lieferanten oder Normierungsinstitutionen. Bei den Adressaten geht es hauptsächlich um die Adressaten der Kommunikation; entsprechend wird zwischen "Business to Consumer (B2C)" - und "Business to Business"--Standards sowie Mischformen differenziert. Im ersten Fall werden die Endkonsumenten angesprochen, und im zweiten Fall geht es um die zwischenbetrieblichen Transaktionen. Die B2C-Standards heben gegenüber den Konsumenten meistens besondere Produkt- oder Prozesseigenschaften hervor.

Im Fokus von Zertifizierungssystemen können Systeme, Verfahren, Prozesse oder Produkte stehen. Kennzeichnend für die erstgenannten Zertifizierungssysteme sind Systemaudits, die in aller Regel Mindestqualitäten im Markt sichern sollen. Im Bereich der ökologischen Landwirtschaft steht dagegen eher die Auditierung der Produktionsprozesse im Vordergrund. Der Produktfokus spielt bei der Klassifizierung von Lebensmitteln (z.B. als geprüfte Markenqualität) eine Rolle.

Hinsichtlich der Ziele kann zwischen der Absicherung von Mindeststandards und der Differenzierung von Produkten unterschieden werden. Die Mindeststandards sollen die Qualitätsunsicherheiten im Markt reduzieren. Kennzeichnend für dieses System ist eine starke Orientierung an gesetzlichen Regelungen und DIN-Vorschriften. Die Produktdifferenzierung soll bestimmte Produkteigenschaften absichern und so den Kunden an die Anbieter binden bzw. seine Zahlungsbereitschaft erhöhen. Die Differenzierung mit Hilfe von Produktlabeln soll bestimmte Produkt- oder Prozesseigenschaften hervorheben und an den Endverbraucher kommuniziert werden.

Nach der geographischen Ausdehnung kann zwischen lokalen, regionalen, nationalen und internationalen Standards unterschieden werden. Lokale Standards erstrecken sich nur über ein überschaubares Gebiet, z.B. wenige Landkreise. Regionale Standards beziehen sich auf die Zertifizierungssysteme bspw. eines bestimmten Bundeslandes. Das Q\&S-System ist ein typisches Beispiel für ein Zertifizierungssystem, das hauptsächlich auf nationaler Ebene zu finden ist. Internationale Standards sind in verschiedenen Ländern zu finden (z.B. GlobalGAP). 
Die Teilnehmeranzahl kann je nach Zertifizierungsstandard sehr unterschiedlich ausfallen. Das System mit der größten Teilnehmeranzahl weltweit ist die ISO 9001 mit knapp 900 Tsd. Mitgliedern. Für die Landwirtschaft ist vor allem der GlobalGAP Standard mit 71 Tsd. Mitgliedern weltweit relevant; das deutsche Q\&S-System hat über 100.000 Teilnehmer.

Bei der Unterscheidung der Reichweite geht es um die Anzahl der Wertschöpfungsstufen, die durch das Zertifizierungssystem abgedeckt werden. Standards wie die GlobalGAP oder IFS umfassen nur eine Wertschöpfungsstufe, währenddessen das System Qualität und Sicherheit alle Wertschöpfungsstufen, von der Erzeugung bis hin zum Handel, abdeckt (vgl. Gawron/Theuvsen 2009).

\section{Qualitätssicherung für muslimische Verbraucher}

Muslime stellen mit rund 1,5 Mrd. Menschen die zweitgrößte religiöse Gruppe auf der Welt dar. Derzeit leben in Westeuropa über 20 Mio. Muslime, davon rund 3,5 bis 4,2 Mio. in Deutschland. In Deutschland werden alleine rund drei Mio. Menschen mit Migrations-hintergrund dem Herkunftsland Türkei zugerechnet.

Aygün (2005) stellt fest, dass die Ursprungskultur als kultureller Einfluss große Wirkung auf die Einkaufsstättenwahl hat. In Deutschland hatte die erste Generation der zugewanderten Türken kaum Möglichkeiten, Lebensmittel nach den religiösen Ernährungsvorschriften der Muslime zu konsumieren. Mittlerweile haben sich die Konsummöglichkeiten jedoch erweitert. Muslime kaufen viele importierte Lebensmittel, etwa Obst, Gemüse und insbesondere Fleisch, in muslimischen Geschäften anstatt in Filialen hiesiger Lebensmittelkonzerne (Schlossberger 2011). Die Muslime mit unterschiedlichen kulturellen, ethnischen und religiösen Besonderheiten wollen sich in ihrer großen Mehrheit nach den Vorgaben ihrer Religion ernähren. Zu ihnen gehören die Speisevorschriften, die nicht nur von streng religiösen Muslimen eingehalten werden. Die diesen Vorschriften genügenden Lebensmittel werden als „Halal“ bezeichnet. Weder in Deutschland noch innerhalb der EU existiert allerdings derzeit - abgesehen vom Codex Alimentarius - eine „Halal-Norm“ oder eine lebensmittelrechtliche Regelung für die Verwendung des Terminus „Halal“(Bednarszky 2009).

Halal (arabisch) oder helal (türkisch) bedeutet erlaubt, statthaft, zulässig, recht- bzw. gesetzmäßig oder legitim. Im islamischen Recht wird er für den Begriff für die statthafte Verhaltensweise sowie für die zulässigen Speisen in Zusammenhang mit Handlungen verwendet.

Die Speise-, Trink und Schlachtvorschriften beziehen sich auf den Koran, Überlieferungen aus 
dem Leben des Propheten Muhammed und Urteile der verschiedenen islamischen Rechtsschulen (Mohagheghi 2009). Der Nachfrage nach islamisch konformen Produkten wird ein enormes Wachstumspotenzial attestiert und bildet allerdings bislang noch einen neuen Nischenmarkt. Nicht nur im Lebensmittelbereich, auch im Bereich Gesundheit und Kosmetik achten die Muslime auf die Inhaltsstoffe der Produkte.

Gemüse und Obst sind weitgehend unkritische Artikel und auch bei den verarbeiteten Lebensmitteln, z.B. bei verarbeiteten Kartoffelprodukten, sind die Anforderungen zur Erreichung des Standards gering: Reinigungsmittel müssen alkoholfrei sein, Sämtliche Zusätze müssen Halal-zertifiziert sein. Grundsätzlich stehen daher nicht Obst und Gemüse im Fokus, sondern Schlachtung, Fleisch und Fleischverarbeitungsprodukte sowie Molkereiprodukte. Im Koran (Sure 5, Vers 3) gehören folgende Gruppen zu den verbotenen Nahrungsmitteln (,haram“) die für Muslime nicht gestattet sind: Aas, Blut, Schweinefleisch und Schweineprodukte (z.B. Schweinegelatine), Tierleichen, welche von anderen Tieren getötet wurden, kranke Tiere, nicht fachgemäß getötete Tiere und Alkohol (EHZ 2010). Ferner gibt es wichtige Richtlinien für den Schlachtungsprozess: Das Tier muss auf eine bestimmte Art und Weise geschlachtet werden, um von muslimischen Verbrauchern verzehrt werden zu können. Schlachten nach islamischem Recht bezeichnet man als „Schächten“. Beim Schächten gilt: a) Der Schächter muss ein Muslim sein. b) Bevor das Tier geschächtet wird, muss es in Richtung Mekka (der Gebetsrichtung) gerichtet werden. c) Unmittelbar vor der Schlachtung muss vom Schächter der Name Allahs ausgesprochen werden; dann mit einem scharfen, metallischen Schneidewerkzeug mittels eines schnellen Schnittes der Hals vom Körper getrennt. Nach der Schlachtung muss das Tier möglichst vollständig ausbluten (OIC 2009). Es ist zu berücksichtigen, dass der Islam eine Betäubung der Tiere vor dem Schächten nicht grundsätzlich verbietet (nach OIC/SMIIC). Nach den allgemeinen Richtlinien für Halal-Lebensmittel dürfen die Tiere mittels Elektrizität betäubt werden. Hier ist es sehr wichtig, dass sichergestellt wird, dass die Tiere dabei weder gequält noch vor der Schächtung getötet werden. Die Stärke des elektrischen Stroms und seine Dauer werden von der Zertifizierungsstelle validiert und festgestellt und hängen von der Art und dem Gewicht des Tieres sowie anderen Faktoren ab (z.B. bei Hühnern 0,25 bis 0,50 Ampere und 3 bis 5 Sekunden, bei Lämmern 0,50 bis 0,90 Ampere und 2 bis 3 Sekunden, bei Kälbern 0,50 bis 1,50 Ampere und 3 Sekunden) (Karakoc 2012).

Im Jahr 2010 machten Halal-Produkte 17\% des globalen Nahrungsmittelumsatzes aus. Jedes Jahr wächst der Markt um 16 \%, in Europa betrug der Umsatz zuletzt 67 Mrd. Dollar, in Deutschland 
rund 2 Mrd. Dollar pro Jahr. Von daher steigt bei den Unternehmen der Lebensmittelindustrie das Interesse, Produkte speziell für Verbraucher islamischen Glaubens anzubieten (Tauber 2011).

Im Bereich der Halal-Zertifizierung sind viele verschiedene muslimische Einrichtungen, wie islamische Zentren und Moscheen, unterschiedlicher muslimischer Glaubensprägungen oder islamische Rechtsschulen aktiv, was wiederum zu einer Erschwernis führt, einheitliche Standards zu setzen und eine geordnete Kontrolle durchzuführen. Weltweit werden von etwa 130 Unternehmen und verschieden muslimischen Organisationen Halal-Zertifizierungen als Dienstleistungen angeboten. Zumeist wird die Einhaltung der von einer Glaubensgemeinschaft definierten Halal-Anforderungen von Angehörigen der entsprechenden Gemeinschaft oder Moschee bzw. durch die beauftragten Kontrolleure geprüft. Hierbei begutachtet der Kontrolleur die Produktionsstätte und zertifiziert einzelne Produkte oder Produktchargen, wobei sich die Kosten für ein Halal-Zertifikat nach dem Gewicht oder der Anzahl der zertifizierten Produkte bemessen. Die Richtlinien, nach welchen zertifiziert wird, unterscheiden sich dabei von Organisation zu Organisation. Weitere unangekündigte Kontrollen werden mehrmals jährlich anberaumt, um die Einhaltung der vorgegebenen Kriterien zu überprüfen.

Die Organization of Islamic Cooperation (OIC) erarbeitete in Zusammenarbeit mit dem Standards and Metrology Institute for Islamic Countries (SMIIC) drei Richtlinien für Zertifizierungssysteme, die von 39 der gegenwärtig 57 Mitgliedstaaten der OIC zum 17. Mai 2011 in Kraft gesetzt wurden:

- OIC/SMIIC 1: 2011, General Guidelines on Halal Food,

- OIC/SMIIC 2: 2011, Guidelines for Bodies Providing Halal Certification und

- OIC/SMIIC 3: 2011, Guidelines for the Halal Accreditation Body Accrediting Halal (Sahin et al. 2014).

Ziel des OIC/SMIIC ist es, allen Lebensmittelproduzenten und dem Lebensmittelhandel eine einheitliche und qualifizierte Beurteilungsgrundlage der Halal-Konformität von Lebensmitteln anzubieten und damit den Muslimen die Halal-zertifizierte Ernährung zu erleichtern sowie Barrieren, die bisher den Markteintritt für den Handel erschwerten, abzubauen.

In der Türkei bietet seit 2011 das Türkische Institut für Normung und Standardisierung (Türk Standartları Enstitüsü, TSE) die Halal-Zertifizierung TS OIC/SMIIC Helal an. In Deutschland bietet die SGS Germany GmbH die Halal-Zertifizierung für Lebensmittel Verarbeiter an. Der Zertifizierungsprozess beginnt nach der Anmeldung eines Betriebes bei einer der anerkannten 
Zertifizierungsstellen. Ein muslimisches Zertifizierungsaudit beurteilt gemäß einer Checkliste die Erfüllung der Anforderungen. Die Audits werden in regelmäßigen Abständen durchgeführt, fallweise erfolgen unangekündigte Kontrollaudits. Probenahmen erfolgen durch einen muslimischen Auditor und Endproduktproben werden mittels PCR-DNA-Analysen durch ein unabhängiges externes Labor überprüft. Weitere Untersuchungen zum Nachweis von Alkohol oder verbotener Stoffen.

In Südostasien werden von circa 300 Mio. Muslimen Halal-Lebensmittel verbraucht. Die Länder Indonesien, Malaysia und Singapur haben staatliche Mandate, um Halal-zertifizierte Produkte zu importieren; diese gelten als die strengsten Halal-Richtlinien der gesamten Welt. Die neutrale und objektive Zertifizierung durch ein weltweit anerkanntes Zertifizierungsinstitut ermöglicht den muslimischen Verbrauchern den sicheren Konsum entsprechend gekennzeichneter, zertifizierter Lebensmittel sowie den Unternehmen der Lebensmittelindustrie den Eintritt in ein wachsendes, überaus sehr lohnendes Marktsegment (Sahin et al. 2014).

\section{Aufbau der Arbeit}

Die in dieser Dissertation zusammengefassten Arbeiten beschäftigen sich mit verschiedenen Aspekten der Qualitätssicherung in der türkischen Agrar- und Ernährungswirtschaft sowie der Zertifizierung für muslimische Verbraucher. Die Arbeit besteht aus vier Teilen: Der erste Teil der Arbeit beschäftigte sich mit der Darstellung der türkischen Agrarwirtschaft und Qualitätssicherung. Teil II erläutert das Thema "Food safety and quality assurance systems in turkish agribusiness: An empirical analysis of determinants of adoption”. Teil III der Arbeit befasst sich mit den "EU requirements of food safety and quality systems: Determinants of perceptions". Die Teile II und III präsentieren die Ergebnisse einer empirischen Erhebung in der Türkei. Des Weiteren widmet sich der letzte Teil der Dissertation (Teil IV) den „Muslimischen Konsumenten in Deutschland: Kenntnis und Bedeutung der Halal- Kennzeichnung“.

Teil I ist in drei Unterkapitel eingeteilt. Zunächst erfolgte eine Darstellung der türkischen Agrarund Ernährungswirtschaft, insbesondere im Hinblick auf strukturelle und betriebliche Merkmale. Die Türkei ist in sieben geographische Gebiete eingeteilt, welche alle einzeln in Bezug auf landwirtschaftliche Produkte und Hauptprobleme der Gebiete erläutert wurden. Im Unterkapitel Produktionsstruktur wurde ein detaillierter Überblick über die vielfältigen pflanzlichen und tierischen Produkte geschaffen. Der Abschnitt über die Handelsbeziehungen zwischen der Türkei 
und der EU zeigte auf, wie wichtig Agrarprodukte für die Handelsbeziehungen sind und dass die EU einer der wichtigsten Handelspartner der Türkei ist.

Der Abschnitt mit dem Titel „Qualitätssicherung in der türkischen Agrar- und Ernährungswirtschaft" beschreibt die aktuelle Lage der Qualitätssicherheit nach nationalen gesetzlichen Vorgaben und internationalen Standards und befasste sich folglich mit der Systematisierung von Zertifizierungssystemen und den Möglichkeiten der Qualitätssicherung. Letztlich wurde noch ein allgemeiner Überblick über Qualitätssicherungsnormen für muslimische Verbraucher gegeben. Halal-Standards werden zur Kennzeichnung von Produkten genutzt, die entsprechend den Vorschriften des Islam hergestellt wurden und welche die Ernährung von muslimischen Verbrauchern in Deutschland mit Halal-Lebensmitteln ermöglichen.

Teil II analysiert die Einflussgrößen auf die Zertifizierungsentscheidungen von Unternehmen des türkischen Agribusiness. Hierdurch wird versucht, eine Antwort darauf zu geben, warum die türkischen Unternehmen eine positive Entscheidung treffen, indem sie sich zertifizieren lassen. Fraglich ist, welche Faktoren bei dieser Entscheidung eine Rolle spielen und welche Schwierigkeiten sich bei der Einführung der Zertifikate ergeben. Es wird eine umfassende Analyse über das Annahmeverhalten der Unternehmen in Bezug auf Lebensmittelsicherheitsund Qualitätssicherungssysteme in der türkischen Agrar- und Ernährungswirtschaft dargestellt. Es wird untersucht, welche Wirkungen speziell die Unternehmenscharakteristika auf die Zertifizierungsentscheidungen haben.

Teil III befasst sich mit dem Thema „, EU requirements of food safety and quality systems: Determinants of perceptions“. Die Türkei strebt derzeit den EU-Beitritt an und versucht deshalb, im Hinblick auf die Lebensmittelsicherheit und -qualität den ,acquis communautaire“ der EU zu erfüllen und einzuhalten. Hierbei wird untersucht, ob die türkischen Unternehmen in der Agrarund Ernährungswirtschaft die EU-Verpflichtungen in ihrem Geschäft als Risiko oder als Chance wahrnehmen. Darüber hinaus untersucht die Arbeit einige objektive und subjektive Faktoren, die die Wahrnehmungen verursachen könnten. Ferner werden die Fortschritte und Entwicklungen der Türkei im Hinblick auf die EU-Anforderungen sowie auch die Beziehungen zwischen der Türkei und der EU erläutert. 
Teil IV, der letzte Beitrag der Dissertation, befasst sich mit dem Konsumverhalten von Muslimen in Deutschland im Bereich Halal-Lebensmittel am Fallbeispiel Göttingen. Dieser Abschnitt beinhaltet empirische Informationen über die Bedeutung der Halal-Kennzeichnung von Lebensmitteln für die Konsumenten. Es wird erfasst, wie gut die Befragten mit der HalalKennzeichnung vertraut sind und was sie mit ihr verbinden, welcher Stellenwert ihr beim Lebensmittelkauf beigemessen wird und inwieweit die entsprechende Kennzeichnung Auswirkungen auf die Einkaufsstättenwahl hat. Ferner wird die Mehrzahlungsbereitschaft für Halal-Produkte betrachtet. Der Bekanntheitsgrad der mit Halal gekennzeichneten Lebensmittel, die Erwartungen bei Halal-Lebensmitteln und die Kaufhäufigkeit von Halal-gekennzeichneten Lebensmitteln sind andere wichtige Aspekte, welche in diesem Teil analysiert werden.

Darüber hinaus werden im Anhang der Arbeit die Fragebögen, die im Rahmen der Datenerhebungen in der Türkei und unter muslimischen Verbrauchern in Deutschland verwendet wurden, sowie eine deskriptive Auswertung der Studie zur Qualitätssicherung in der türkischen Lebensmittelwirtschaft dargestellt.

Die Untersuchungen in den oben genannten Teilen II und III wurden mit Hilfe eines Fragebogens durchgeführt. Der vollständig standardisierte Fragebogen besteht aus vier Hauptteilen. Es sind insgesamt 33 Fragen; 11 Fragen sind offene Fragen, 5 Fragen sind Ja/NeinFragen und es gibt geschlossene Fragen. Im ersten Teil sind allgemeine Fragen in Bezug auf die Unternehmenscharakteristika zu finden, z.B. betreffend die Rechtsform des Unternehmens, die Verarbeitungszweige und den Unternehmenssitz. Teil II umfasst die Handelsbeziehungen, Marketing und Export. In Teil III sollten die Unternehmen ihre Wahrnehmung der Qualitätssicherungssysteme wiedergeben, besonders auch unter Berücksichtigung der Wettbewerbsstrategie des Unternehmens, der unternehmerischen Verantwortung, der Reaktion der Mitarbeiter auf die Zertifizierungssysteme sowie zusätzlicher Kosten für die Zertifizierung. Der letzte Teil des Fragebogens beschäftigt sich mit soziodemographischen Angaben. In einer Begleit-E-Mail wurde den Befragten angeboten, dass ihnen die Ergebnisse nach Abschluss der Untersuchung zugestellt werden könnten. 
Die stichprobenhafte Befragung erfolgte nach Zufallsauswahl (random sampling). Die Fragebögen wurden mit Hilfe der Zentralanatolischen Exportunion, in der insgesamt 1.560 Unternehmen organisiert sind, mit einer Begleit-E-Mail an folgende Adressaten verschickt:

- Mitglieder der Kammer der Lebensmittelingenieure von Konya und Ankara

- Die Landwirtschaftskammer in Konya und Ankara

- Die Handelskammern Konya und Ankara

- Die Industriekammer von Konya

- Die Abteilung für Schutz und Kontrolle im Ministerium für Ernährung, Landwirtschaft und Viehzucht in Konya und Ankara

- Die Brot- und Mehlmühlenfabriken in Konya und Ankara

- Der Verband der Eier-Produzenten

- Die Ägäis-Export-Gesellschaft sowie die Istanbul-Export-Gesellschaft

- In Konya und Ankara wurden ferner Unternehmen über einen Zeitraum von jeweils 14 Tage lang im Rahmen der Untersuchung persönlich kontaktiert.

Neben persönlichen Besuchen wurden auch telefonische Kontaktaufnahmen durchgeführt, die Unternehmen erhielten bei Interesse daraufhin den Link zur Online-Befragung.

Die Auswertung der Fragebögen erfolgte mit Hilfe des Programms SPSS - Statistics für Windows, Version 21. Der Zeitraum der Online-Befragung war Juni bis August 2013. Die Zielgruppen waren weiterverarbeitende Lebensmittelunternehmen. Nach der Rückreise nach Deutschland wurden alle eingegebenen Daten bereinigt und auf Deutsch übersetzt. 


\section{Literaturverzeichnis}

Amtsblatt Nr. 27610 vom 13. Juni 2010: Veterinärdienste, Pflanzenschutz, Lebensmittel und Futtermittelrecht. URL: http://www.resmigazete.gov.tr/main.aspx?home= http://www. resmigazete. gov.tr/eskiler/2010/06/20100613.htm\&main=http://www.resmigazete.gov.tr/eskiler/2010/06/20100613.ht $\mathrm{ml}$.

Amtsblatt Nr. 28710 vom 17 Juni 2013: Türkisches Lebensmittelkodex Kommuniqué über Kunststoffmaterialien und Gegenstände in Kontakt mit Nahrung. URL: http://www.resmigazete. gov.tr/main.aspx?home=http://www.resmigazete.gov.tr/eskiler/2013/07/20130717.htm\&main=http://www .resmigazete.gov.tr/eskiler/2013/07/20130717.html.

Aygün, T. (2005): Deutschtürkisches Konsumentenverhalten, Eine empirische Untersuchung zur Einkaufsstättenwahl im Lebensmitteleinzelhandel, Lohmar und Köln, Eul Verlag.

Bednarszky, H. (2009): Neutralität schafft Vertrauen, Marktpotenziale Muslim-konformer Lebensmittel. Halal-Symposium, Hannover Congress Centrum.

Burrell, A., und A. Oskam (2005): Turkey in the European Union, Implications for Agriculture, Food and Structural Policy, Wageningen University, Wageningen, The Netherlands, CABI Publishing.

EHZ - Europäisches Halal Zertifizierungsinstitut (Hrsg) (2010): Halal-Richtlinien für die HalalZertifizierung, Hamburg.

ENVI Delegation (2011): Food safety and Public Health situation in Turkey, ENVI Delegation, November 2-4, 2011, Brussels.

EU-Kommission (2006): Screening report Turkey, Chapter 11- Agriculture and Rural Development. URL: http://ec.europa.eu/enlargement/pdf/turkey/screening_reports/screening _ report_11_tr_internet_en.pdf.

EU-Kommission (2007): Screening Report Turkey, Chapter 12- Food Safety, Veterinary and Phytosanitary Policy. URL: http://ec.europa.eu/enlargement/pdf/turkey/screening_reports/screening _report_12_tr_internet_en.pdf.

EU (2007): URL: http://europa.eu/rapid/pressReleasesAction.do?reference=MEMO/07/609\& format $=$ HTML\&aged $=0$ \&language $=$ DE\&guiLanguage $=$ en .

EU Kommission, (2010): URL: http://ec.europa.eu/agriculture/enlargement/countries/turkey/ profile_en.pdf.

EU Kommission (2011- 2014): Turkey Progress Report: Fortschrittsberichte der EU Kommission der letzten vier Jahre, Kapitel 12: Lebensmittelsicherheit, Veterinärwesen und Pflanzenschutzpolitik. 
Europäische Kommission (2013a): Turkey Progress Report: Commission staff working Document, European Commission, 16.10.2013, Brussels.

Europäische Kommission (2013b): Europäische Kommission, Erweiterung URL: http://ec.europa.eu/enlargement/countries/detailed-country-information/turkey/index_de.htm.

European Commission (2014): IPA II: Enlargement Package, Instrument for Pre-Accession Assistance (IPA II), Indicative Strategy Paper for Turkey, 2014-2020.

Eurostat (2013): Trade in Turkey. URL: http://rade.ec.europa.eu/doclib/docs/2006/september/ tradoc_113456.pdf. (Abgerufen am 10.12.2013).

FAO - Food and Agriculture Organization of the United Nations (2012): Eastern Europe and Central Asia Agro-industry development country brief Turkey. Regional Office for Europe and Central Asia. URL: http://www.fao.org/fileadmin/user_upload/Europe/documents/Publications/ AI_briefs/AI_breiefs2012/fao_turkey.pdf.

GAP (2010): Republic of Turkey Prime Ministry South-Eeastern Anatolia Project Regional Development Administration. URL: http://www.gap.gov.tr/english

Gawron, C.-J. und L. Theuvsen (2009): Certification Schemes in Central and Eastern Europe: A Status Quo Analysis in the Agri-food Sector, Polish Journal of Food and Nutrition Sciences, $59(1), 5-10$.

Gawron, C.-J. und L. Theuvsen (2009): Zertifizierungssysteme des Agribusiness im interkulturellen Kontext. Forschungsstand und Darstellung der kulturellen Unterschiede. Diskussionspapier, Nr. 09030903 des Departments für Agrarökonomie und Rurale Entwicklung, Georg-August-Universität Göttingen.

Generalsekretariat des Schwarzen Meeres Exporters Association (2009): URL: http://www.kib.org.tr/media/2009ulke.pdf.

Geographische türkische Regionen (2010): URL: http://www.sosyalokulu.com/altsayfa.asp? nedir $=$ sayfa\&id $=165$.

Germany Trade \& Invest (2007): URL: https://www.gtai.de/DE/Content/_SharedDocs/ Anlagen/PDF/EU-Drittlandprogramme/ipa-ziele-und-foerderprioritaeten,property=publicationFile.pdf ?show $=$ true.

Grethe, H. (2003): Effects of Including Agricultural Products in the Customs Union between Turkey and the EU. A partial Equilibrium Analysis for Turkey, Peter Lang Verlag, Frankfurt a. Main u.a.

Grethe, H. (2005): Der türkische Milchmarkt: Chancen und Perspektiven. In: Deutsche Milchwirtschaft, 56. Jg., H. 19, S. 838.

Hatanaka, M., C. Bain and L. Busch (2005): Third-party certification in the global agrifood system. In: Food Policy, Vol. 30, 354-369. 
IPA II (2014): Instrument for Pre-Accession Assistance, Delegation der Europäischen Union in die Türkei. URL: http://ec.europa.eu/enlargement/pdf/key_documents/2014/20140919-csp-turkey.pdf

Karakoc, Ö. (2012): Halal Food Certification, New approaches at comformity assessment. Turkish Standards Institution, Ankara.

Keban Projekt (2007): URL: http://www.keban.gov.tr/bfaydalari.html, Offizielle Government Website.

Koç, A.A., S. Asci, H. Alpas, F.H. Giray and S.H. Gay (2011): Food Quality Assurance Schemes in Turkey. European Commission, Joint Research Centre, Institute for Prospective Technological Studies, JRC Scientific and Technical Reports, Spain, Report EUR 24672 EN - 2011.

Kommission der Europäischen Gemeinschaften (2004): Regelmäßiger Bericht über die Fortschritte der Türkei auf dem Weg zum Beitritt, Brüssel. URL: http://ec.europa.eu/ enlargement/archives/pdf/key_documents/2004/rr_tr_2004_de.pdf.

Krieger, S. (2007): Qualitätssysteme der Agrar- und Ernährungswirtschaft Entwicklung eines Beratungssystems zur Kosten- und Nutzenschätzung, Dissertation Rheinische FriedrichWilhelms-Universität Bonn.

MfELV (2014): Ministerium für Ernährung, Landwirtschaft und Viehzucht, Lebens- und Futtermittel Service, Laboratorien 01.04.2014, Ankara. URL: http://www.tarim.gov.tr/Konular/ Gida-Ve-Yem-Hizmetleri/Laboratuvarlar.

Ministerium für EU- Angelegenheiten (2014): Republic of Turkey, Ministerium für EUAngelegenheiten, Financial Cooperation Directorate, Ankara. URL: http://www.abgs.gov.tr/ index.php? $\mathrm{p}=5 \& \mathrm{l}=2$.

Ministry for EU Affairs (2013): Republic of Turkey, Ministry for EU Affairs, 2013 Progress Report prepared by Turkey, December 2013, Ankara.

Mohagheghi, H. (2009): Muslime heute und die Bedeutung von Halal in der Ernährung: Marktpotenziale muslim-konformer Lebensmittel Halal-Symposium, Congress Centrum, Hannover.

OIC (2009): OIC Standards - general guidelines on Halal food. URL: www.halalworld.org/ download/standard/filegallery/47/OIC\%20Standards-General\%20Guidelines\%20on\%20Halal\%20Fo od.pdf.

Pelikan, J., M. Brockmeier, W. Kleinhanß, A. Tietz und P. Weingarten (2009): Auswirkungen eines EU-Beitritts der Türkei. Bundesforschungsinstitut für Ländliche Räume, Wald und Fischerei, Landbauforschung Völkenrode, Sonderheft 329.

RASFF (2013): The Rapid Alert System for Food and Feed, the Health and Consumers Directorate-General of the European Commission (RASFF), 2013 Annual Report. URL: $\mathrm{http} / / /$ ec.europa.eu/food/safety/rasff/docs/rasff_annual_report_2013.pdf. 
Sahin, A., T. Pekkirbizli, M. Kayser und L. Theuvsen (2014): Muslimische Konsumenten in Deutschland: Kenntnis und Bedeutung der Halal-Kennzeichnung. In: Berichte über Landwirtschaft, Bd. 92 (2). S- 1-12..

Schlossberger, F. (2011): IEM-Information Halal-Food - Standards. Bayerische Landesanstalt für Landwirtschaft. Institut für Ernährung und Markt, München.

Sen, F. (1986): Türkei. 2. Aufl., 26, 19-20, Verlag C.H. Beck, München

Tauber, J. (2011): Halal - Erlaubt und Zulässig. Der Islam und seine Vorschriften. In: Hygiene Report, 2/2011, 18-22.

Theuvsen, L. (2006): Vorlesungsskript Qualitätsmanagement - QM-Systeme im Agribusiness, Georg-August-Universität Göttingen.

Theuvsen, L. und J.-C. Gawron (2007): Certification Schemes in the German Food Business: Classification and Evaluation from the Perspective of Small and Medium-Sized Enterprises, Vortrag, IAMA, Parma, Italien.

Turkish Statistical Institute (2006): Agricultural Structure Production, Price, Value. No. 3123.

Türkische Lebensmittel-Verordnung vom Ministerium für Ernährung, Landwirtschaft und Viehzucht in Ankara (2011): URL: http://www.tarim.gov.tr/Sayfalar//IceriklerDetay.aspx?rid=1099 $\&$ NodeValue $=499 \&$ KonuId $=123 \&$ ListName $=$ Icerikler. (Abgerufen am 10.12.2013).

Türkisches Ministerium für Industrie und Handel (2010): Yillik Pamuk Raporu.

Türkisches Ministerium für Landwirtschaft und ländliche Gebiete (MARA) (2004): URL: http://www.tarim.gov.tr/Files/Mevzuat/kanun_son/TKB_Kanunlar/GIDALARINURETIMI.pdf.

Vural, H. und H. Fidan (2007): Animal Production in Turkey and the Features_of Animal Farm, 13 (2), S. 49-59.

WTO - World Trade Organization (2009): Trade Profiles - Turkey, Germany. URL: http://stat.wto.org/Home/WSDBHome.aspx?Language=E [04.02.2009]. 
Teil II: Food safety and quality assurance systems in Turkish agribusiness: An empirical analysis of determinants of adoption

Tuba Pekkirbizli, Mohamad Isam Almadani and Ludwig Theuvsen

Vorgesehen zur Einreichung beim

Journal for Eastern European Management Studies 


\title{
Food safety and quality assurance systems in Turkish agribusiness: An empirical analysis of determinants of adoption
}

\author{
Tuba Pekkirbizli, Mohamad Isam Almadani and Ludwig Theuvsen
}

Georg-August University, Department of Agricultural Economics and Rural Development, Göttingen, Germany

\begin{abstract}
Since the Turkish food trade has developed rapidly during the last decade, the adoption of food safety and quality assurance systems has become of major significance in the Turkish food industry. Nonetheless, the adoption of these systems is still considered a weakness in the Turkish agri-food sector. Against this background, this study presents a comprehensive analysis of firms' adoption behavior with regard to food safety and quality assurance systems in Turkey. The data originate from 106 Turkish food industry enterprises and were gathered using a questionnairebased survey. Multiple regression analyses were used to analyze the relationship between the firms' level of food safety and quality assurance standards adoption and firm characteristics. The results indicate that firm characteristics play a major role in determining the adoption of such practices. The findings show that adoption behavior varies widely among individual firms according to firm size, legal form of ownership, region of ownership and control, export orientation and major market served. The findings have manifold implications for managerial and political decision-makers.
\end{abstract}

Keywords: Food safety, food quality, Turkish agri-food industry, certification, adoption behavior

\section{Introduction}

Agriculture plays an important role in the Turkish economy, contributing roughly $10 \%$ to GDP (gross domestic product) over recent years (Koç et al. 2011; Cakmak and Dudu 2013). Agriculture is also a major source of employment in Turkey since a quarter of the total workforce belongs to the agricultural sector (Cakmak and Dudu 2013; Fellmann et al. 2011). The various agricultural resources, varied and in many cases favorable climate conditions, a young and dy- 
namic population and the country's strategic geographical location in the world are reflected in Turkey's status as a major producer of many agricultural products including cereals, nuts, cotton, tobacco, milk, fruits and vegetables (Alpay et al. 2013; Fellmann et al. 2011). In the last decade, statistical indicators have revealed conspicuous growth in various agricultural businesses. As a result, the agricultural sector has maintained its position as the leading sector of the strong Turkish economic development. In the ranking of agricultural sector sizes, Turkey ranked first in Europe by 2010; moreover, it ranked seventh globally in the same year (Alpay et al. 2013). The notable growth of agricultural production was accompanied by a parallel development of agroindustries. The contribution of agro-industries to the net domestic product of the transformation industries (NDPTI) reached 49\% in 2008 (Artik 3013; ISPAT 2014). Turkish food sector enterprises have improved rapidly during the last few years (Alpay et al. 2013). Furthermore, the Turkish food industry aims to be among the top five globally by 2023 (ISPAT 2014).

The strong development and high performance of agro-industries coupled with exportoriented strategies was the major factor in sustaining net exports in the Turkish agri-food trade (Cakmak and Dudu 2013). Turkey recorded a positive net trade from agribusiness with US \$ 4.5 billion in 2012. Furthermore, the country has become a regional supply center for the Middle East and North Africa (MENA) region (ISPAT 2014) and has contributed significantly to global food security by exporting more than $8 \%$ of its food production (Cakmak and Dudu 2013).

Despite the rapid development of the Turkish agro-industry, one of the most critical weaknesses in the field is enterprises' implementation of food safety and quality assurance standards, since the implementation rate is still under the satisfactory level. Additionally, preparation for EU accession requires more orientation towards further standards adoption, which should begin in the early stages of the accession process (Koç et al. 2011). In world global markets, regulations concerning the general principles and requirements of food safety and healthy food have increased. For example the European Union (EU) has set strict requirements on the hygiene of food entering the market based on hazard analysis and critical control points (HACCP) methodology and other principles of food law (CBI 2012; Leible et al. 2014).

The Turkish food industry is required to take into consideration such factors as food safety and quality assurance systems in response to legal standards in importing countries, the private standards of global retailers and other customers, and increasing consumer awareness regarding food safety. In many countries, certification systems, for instance, have become quasi-mandatory and have often turned out to function as barriers to trade for non-certified exporters (Meuwissen 
et al. 2003; Anders and Caswell 2009). Other exporters suffer from rejection of their agricultural and food products grounds such as high pesticide residues (Henson and Blandon 2007). However, as food quality has only recently become an important issue in Turkey, there are no comprehensive studies on food quality assurance schemes, and many gaps in this area need to be filled (Koç et al. 2011). One of these gaps is the enterprises' implementation of food safety and quality assurance systems, which is considered of major significance for the future development of Turkey's food industry.

Knowledge of the determinants that may influence the decision to adopt food safety and quality assurance systems is important in efforts toward further develop of such systems by food processing firms (Hassan et al. 2006). On the other hand, Henson and Holt (2000) concluded that the generalization of the determinants of the level and type of food controls adopted by firms at a particular point in time is not possible. In this context, this paper examines the factors that determine the adoption of food safety and quality assurance systems by Turkish agri-food firms. Furthermore, it analyzes the extent to which such incentives exist or are firm-specific and whether more general insights into the decision to adopt can be derived. Although much research on food safety and quality assurance systems in the agribusiness sector has been conducted, most studies have focused only on a single practice, such as the adoption of ISO 9000 in South African agribusiness firms (Turner et al. 2000), or a single food industry sector, such as the Turkish dairy and meat processing business (Çobanoğlu et al. 2013). This study goes beyond existing studies by taking into account a broader set of food safety and quality assurance systems and agri-food industries. Unlike most previous Turkish studies, data were collected in Turkey from a large sample size. This study supports policy makers and regulators with additional empirical evidence on food safety and quality assurance practices in food processing firms to define and apply control programs tailor-made for each firm based on its characteristics. It also has various managerial implications.

\section{Food safety and quality assurance systems in Turkish agribusiness}

Food safety and quality have gained increasing relevance in Turkey due to such factors as the ongoing internationalization of agri-food trade and the status of Turkey as an EU accession candidate. Since 2005 Turkey has been dealing with the 35 chapters of the acquis communautaire. In 2012 the negotiations on "Chapter 12: Food Safety, Veterinary and Phytosanitary Poli- 
cy" began. The latest annual progress report demonstrated the remarkable progress Turkey has made with regard to legislation on food quality and safety (European Commission 2013).

In Turkey the Ministry of Food, Agriculture and Livestock (MFAL) is responsible for setting legal standards with regard to food safety, livestock and plant health. The ministry includes 13 institutions, which are responsible for different tasks, for instance the development of livestock and arable production, aquaculture, animal and plant protection and quarantine; food and feed registration; control and approval of licenses, pesticides and veterinary medicine; fishery and hunting; the health of aquaculture; environmental protection and rules for emergency relief; administration for the effective support of agriculture and regulation of agricultural markets; EU and international relations; and agricultural research and policy (Keenan et al. 2011). The Directorate General of Food and Control is responsible for plant and livestock controls, border controls for arable and livestock products, food and feed companies and laboratory analysis, risk analysis and quarantine. Thus, this division of the ministry is responsible for major aspects of food safety and quality in the Turkish agri-food sector.

In 2010 the MFAL released law No. 5996 on "Veterinary services, plant health, food and feed"; this law adapted Turkish legislation to Regulation (EC) 178/2002 (Official Gazette 2010). This law embraces the Regulation on Turkish Food Codex which covers the following areas: food additives, flavoring substances, contaminations such as toxins, metal and foreign matters, pesticide residues, and veterinary medicine residues, food hygiene, required characteristics of food manufacturers, packaging, labelling, food delivery and storage, and sample taking and analytical methods. The food codex can be revised if necessary. In 2013, for instance, the codex was revised with regard to Regulation (EC) 10/2011 on "Plastics Intended to come into Contact with Food" (Official Gazette 2013).

The concept of hazard analysis and critical control Point (HACCP) was first introduced into the Turkish food codex in 1997. Since then many Turkish food manufacturers, wholesalers and retailers have implemented HACCP. Exporters coordinate their activities regarding HACCP with the EU since these companies are required to comply with HACCP guidelines under the tariff union. After a period of adaption to the new regulation, there were obligatory controls and official inspections of compliance with HACCP standards. On March 31, 2008, a regulation on inspection and control of food safety and food quality was put into effect, making HACCP compulsory for all food processors (Koç et al. 2011). 
Besides private standards, certification schemes have gained increasing relevance in Turkey. A study by Gawron and Theuvsen (2009) on the prevalence of ISO 9001, GlobalGAP, the German Q \& S standard, Demeter, BRC Global Standard, IFS and PDO/PGI and TSG systems in Central and Eastern Europe showed that Turkey was in first place regarding the number of certificates issued overall, followed by Hungary and Poland. However, the number of certificates issued per one million inhabitants turned out to be by far the highest in Hungary (97.8). Although the numbers for Poland (25.4), Slovenia (25.0), Turkey (20.9), the Czech Republic (18.4) and Croatia (18.2) are much lower, the authors conclude that Central and Eastern Europe (including Turkey) was in the middle of a catch-up process regarding the prevalence of certification schemes.

\section{Literature review}

Many indicators were detected as incentives for enterprises to follow food safety and quality practices, comply with standards or even implement third-party audit-based certification schemes. Buzby and Frenzen (1999) summarized the factors that determine a firm's level of food safety by the combination of product liability, governmental regulations, and market forces.

Hobbs et al. (2002) argued that the essential factors driving change in the approach to food safety in Canada have been external ones. Legal requirements were indicated early on to be external incentives to achieve food safety and quality standards in order to enhance national and international consumer confidence in the country's food systems (Huff and Owen 1999; Woteki 2000). In addition to legal requirements, incentives to meet the requirements of consumers and customers can also drive adoption externally. Customers such as large retailers or food service operators can exert pressure to force food processors to implement enhanced safety and quality assurance systems (Golan et al. 2004; Lindgreen and Hingley 2003).

Some internal incentives, such as profit maximization and economies of size, can also influence firms' willingness to implement certification systems. Thomsen and McKenzie (2001) suggested that, if there is a demand on the part of consumers, profit maximization can partly encourage firms to spend resources to provide a certain level of safety. An increase of firm profits can also be achieved through avoidance of costs related to food contamination occurrence and liability claims (Jayasinghe-Mudalige and Henson 2007); other benefits can stem from the enhancement of internal efficiency, such as the improved design of business processes that can result from standard adoption (Holleran et al. 1999; Henson and Holt 2000; Fouayzi et al. 2006; 
Jayasinghe-Mudalige and Henson, 2007). Economies of size in food safety technologies will clearly act as an internal incentive for larger firms to adopt such systems, while they act as a disincentive for smaller firms (Herath et al. 2007). Handschuch et al. (2013) indicated that the analysis of the certification decisions of Chilean raspberry producers showed that small-scale farmers are less likely to implement food safety standards. In contrast, Mensah and Julien (2011) concluded that there is no significant effect of enterprise size on compliance with food safety practices in the British food and drinks manufacturing sector.

In addition to external and internal factors, other factors may also affect a firm's willingness to adopt food quality and safety systems, for instance, reputation and reduction of transaction costs. The enhancement of reputation, or brand name capital, was early detected as an important incentive (Hayek 1948; Marshall 1949 as cited in Klein and Leffler 1981). Firms with branded products are more likely to explore ways of expanding their markets and protecting their brands. Thus, such firms will be more likely adopt enhanced food safety and quality assurance practices (Herath et al. 2007). Heyder et al. (2012) showed similar results for investments in tracking and tracing systems in the food industry. Transaction cost minimization among partners in the supply chain is also likely to influence adoption behavior. Lower costs are associated with the reduction of quality uncertainty among buyers, maintenance of separate quality control laboratories and exchange processes, and number of audits (Caswell et al. 1998; Holleran et al. 1999; Luning et al. 2002; Schulze et al. 2006). Zhou and Jin (2009) summarized the factors that affect the implementation of food safety and quality standards by agricultural cooperatives in China by cooperative size, perception of standards, reputation, expected costs and benefits, and destination market.

The relative importance of the aforementioned incentives is definitely affected by firm characteristics and activities. For instance, industry subsector might explain differences in the importance of legal requirements and customer pressure as incentives to adopt enhanced food safety and quality assurance practices. Such incentives are likely to be greatest in the case of industry sub-sectors, where the probability and consequences of food safety failures are greatest, such as the meat and dairy processing sectors, while these risks are relatively smaller for the cereal and bakery sectors (Hassan et al. 2006). Meeting legal requirements was the most important incentive among HACCP adopters in the U.K. dairy processing sector (Henson and Holt 2000). Furthermore, product type affects the size of transaction costs. The costs of investigating, bargaining, and verifying food quality and safety attributes are likely to be greater for meat, fish and dairy products, which have been identified as high-risk commodities (Herath et al. 2007). 
Caswell et al. (1998), Holleran et al. (1999) and Henson and Holt (2000) indicated that not only a firm's prices, costs and profits stimulate a firm's standard adoption, but firm characteristics also have a specific impact on such an adoption decision. Similarly, Madlener and Wickart (2004) denoted that firm characteristics obviously determine the cross-sectional differences among firms in their behavior regarding a new technology. On the other hand, Henson and Holt (2000) revealed that, due to the different firm characteristics and objectives, which vary with the type of product manufactured and the environment in which a given firm operates, it is not possible to generalize the impact of a particular set of incentives on the level and type of food safety controls that are adopted by a particular firm at a particular point in time. While Herath et al. (2007) appreciated the variation in the incentive sets of individual firms, it is probable that a systematic relationship exists between firm characteristics and their propensity toward certification. MacDonald and Crutchfield (1996) indicated that the adoption of a food safety management system is significantly predicted by the levels and forms of innovatively processed products and the major markets served. Hobbs et al. (2002) confirmed that the principal factor that motivated Canadian meat enterprises to use food safety and quality standards was maintaining access to the United States and other foreign markets. A firm's geographical location can also influence its concern. Chiciudean at al. (2014) indicated a strong discrepancy between companies from Northern and Southern regions in Romania regarding the number of traditional products certified. The Northern region will become a source of certified products. The first comprehensive study that empirically analyzed the association between firm characteristics and the adoption decision was Herath et al. (2007). They found, based on data from the Canadian food processing sector, that firm size, industry subsector, country of ownership and control, and level of innovativeness influence the adoption of enhanced food safety and quality assurance practices.

With regard to Turkey and most Central and Eastern European countries, where certification has become a strong trend (Gawron and Theuvsen 2009), the number of studies are quite limited and restricted to a specific sector and/or a specific food safety practice. For example, Mutlu et al. (2003), Baş et al. (2006 and 2007) and Sözen and Hecer (2013) determined certain indicators, difficulties and barriers related to HACCP implementation in the Turkish food businesses. Çobanoğlu and Işın (2007) evaluated the adoption of food safety systems in 38 dried fig businesses. Factors affecting adoption of the organic dried fig in Turkey were investigated by Işın et al. (2007). Demirbas et al. (2008) analyzed the role and importance of milk collection centers in Izmir for assuring food safety in the Turkish dairy sector. Koç et al. (2010) presented 
and evaluated the institutional environment for food quality and safety in Turkey including the relation to EU legislation. In order to determine the impact of export orientation as a motivating force for the adoption of food safety systems, Çobanoğlu (2012) explored its impact on Turkish dried fig firms. Çobanoğlu et al. (2013) investigated the factors affecting the probability of implementation of food safety and quality assurance systems in the dairy and the meat sectors in Aydin, western Turkey.

This paper is, to our best knowledge, the first report related to a comprehensive determination of the complete set of determinants of the implementation of food safety and quality system practices that take into account various Turkish agribusiness sectors rather than just one sector. Furthermore, it considers a broad spectrum of public and private standards. Thus, the main objective of this study is to explore which determinants actually influence the level of implementation of food safety and quality system practices in the Turkish agri-food sector.

\section{Research framework}

Firm characteristics influence incentives to adopt food safety and quality systems. Therefore, the research framework introduces several indicators related to these characteristics in order to examine their relationship with the level of adoption. In this paper "adoption" is defined as the total number of food safety and quality practices adopted by a company; this means that the analysis does not distinguish between the various types of public and private standards, minimum requirements or differentiation standards. As shown in Figure 1, we hypothesize three groups of firm characteristics which are expected to influence adoption behavior: ownership and control, internationalization and structural complexity. With respect to the literature, these groups appear to include all the dominant characteristics that are likely to influence adoption behavior. Furthermore, the study supposes that the subjective information regarding the additional costs of food quality and safety systems, a firm's competitive strategy and the perception of EU requirements are highly related to a firm's motivation to implement food safety and quality standards.

We label the latter determinants as firm characteristic-related factors. The perception of the additional costs that accompany certification system implementation, for instance, seems to be connected with firm size. The monitoring and record-keeping requirements associated with food safety controls are largely fixed costs (Antle 1995). Therefore, within smaller firms, higher per-unit production costs lower firms' tendency to seek certification (MacDonald et al. 1996; 
Ollinger et al. 2004). Similarly, firm size and market served are likely to affect the competitive advantages gained by enhanced food safety and quality systems. For instance, larger and/or export-oriented firms, particularly in branded products businesses, are characterized by stronger competitive incentives compared to small firms that serve local markets (Herath et al. 2007). Consequently, our research design (Figure 1) creates wider vistas to explore more information about adoption behavior in the Turkish agri-food industry. Based on this design, the study's objective can be achieved through two sub-objectives: (1) investigate the impact of firm characteristics (as objective information) on the adoption of food safety and quality practices, and (2) explore whether subjective information reflecting firm characteristic-related factors influences such adoption. 


\section{Figure 1: Research framework}

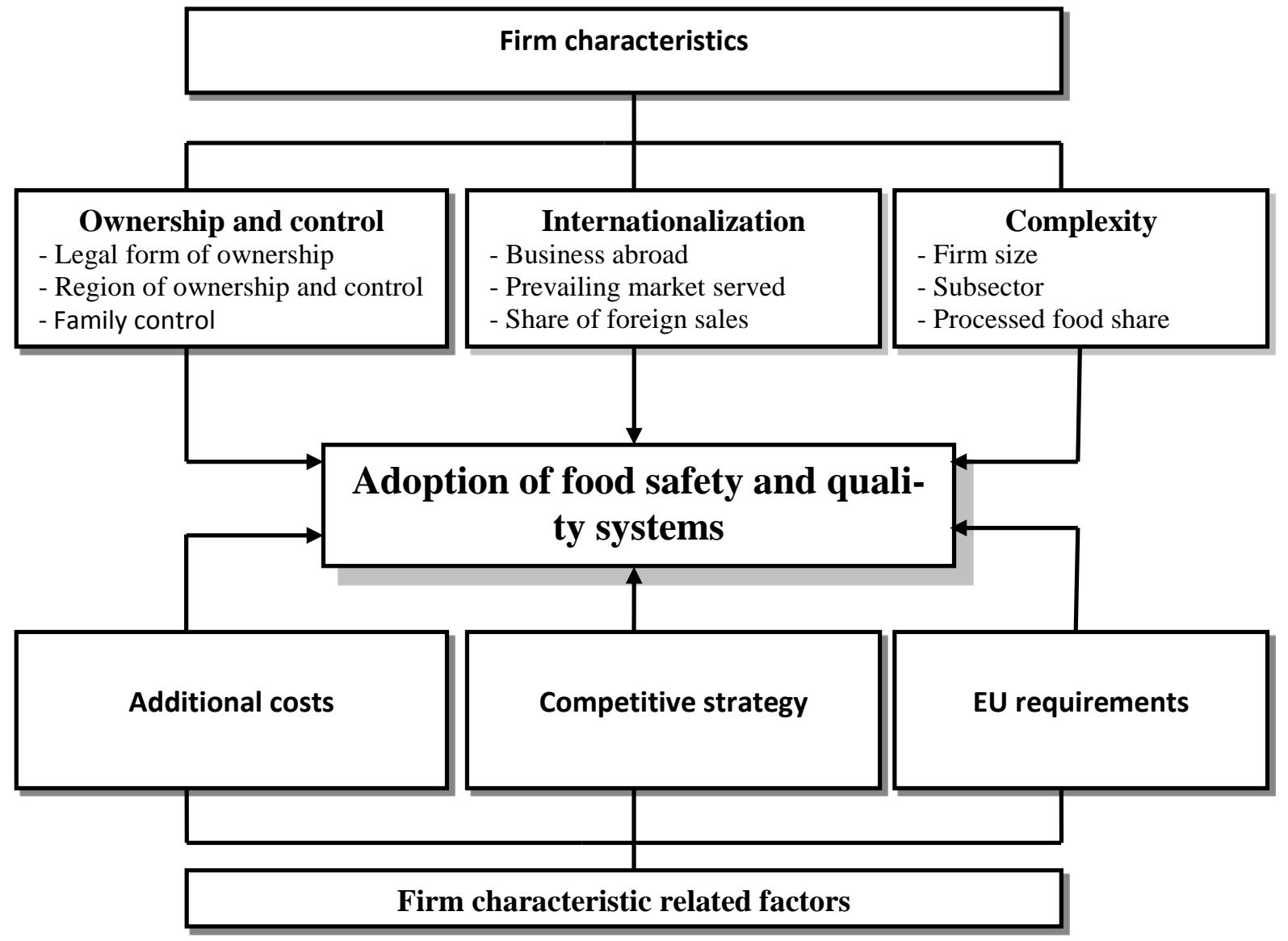

\section{Materials and methods}

The data reported here were collected as part of a larger, questionnaire-based survey of food safety and quality assurance systems in Turkey. Based on an in-depth analysis of previous studies and observations, the survey questions were developed taking into account various aspects related to firm characteristics as well as perceptions concerning the adoption manner. Closed questions (yes/no) were used to detect firm characteristics. Without distinguishing between different types of standards, the 15 different food safety and quality standards that are most prevalent in the Turkish agro-industry were introduced in the questionnaire. Five-point Likert scales ( $1=$ strongly disagree to $5=$ strongly agree) were used to measure respondents' perceptions of firm characteristic-related factors. The questionnaire was pre-tested in sessions with firms in the Central Anatolia region and refined over several stages based on the comments and suggestions received. After a short face-to-face introduction with firms' operators, the questionnaire was mailed in June 2013 to 250 randomly selected food enterprises in Turkey. These in- 
clude various firms selected from lists of addresses acquired from the OAIB Orta Anadolu İhracatçı Birlikleri (Central Anatolian Exporters Union).

The survey covered different food industry sectors, such as pastry (37\%), meat and animal products $(7 \%)$, cereals $(7 \%)$, fruits and vegetables $(3 \%)$ and dairy $(4 \%)$. Some firms $(16 \%)$ are engaged in other subsectors, including drinks, feed, spices, and fats and oils. A quarter of the enterprises surveyed involved more than one food processing type. With respect to the region of ownership and control (Figure 2), the questionnaire comprised all Turkish regions with a concentration on the Central Anatolia region (70\%), with $8 \%$ of the inspected firms located in more than one region. By late August 2013, 199 enterprises had returned the questionnaire. After screening for completeness, the questionnaires of 106 firms were available for statistical analyses (effective response rate: $42 \%$ ).

\section{Figure 2: Official regions in Turkey}

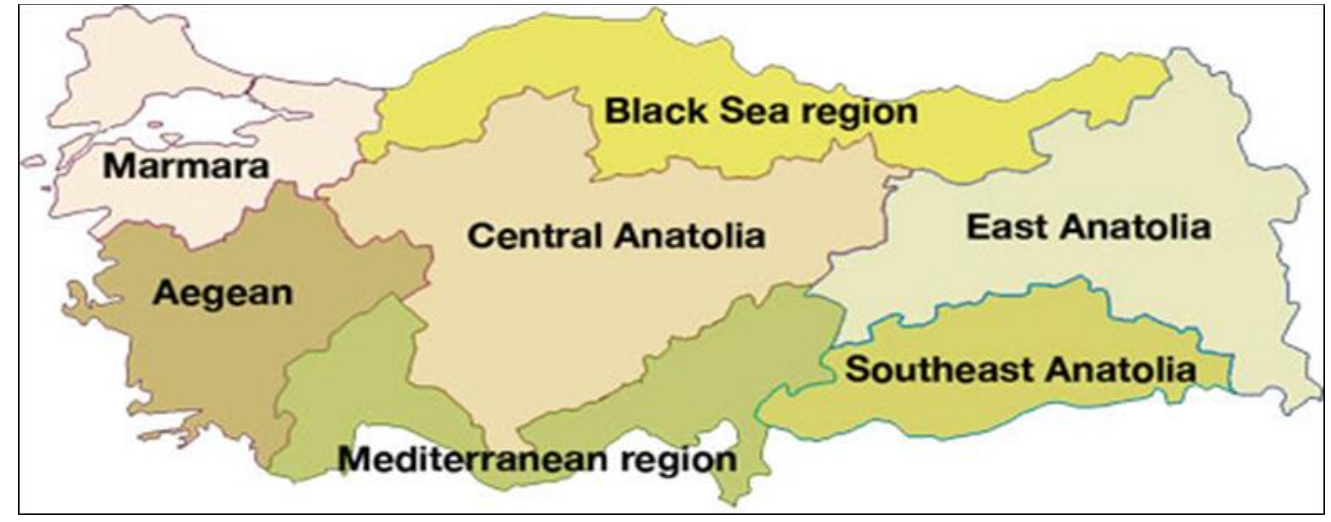

Source: One World - Nations Online, 2014

Descriptive analyses were carried out to examine the variability present among the variables. To investigate the determinants of standard adoption, stepwise multiple regressions were employed twice. First, "firm characteristics" were regressed against the summed score for food safety and quality certifications. Second, "firm characteristic-related factors" were added to the first regression equation to determine their explanatory power. Stepwise regression provides the best combination of independent variables to interpret the dependent one. Preliminary analyses were carried out to verify that there was no violation of the multiple regression assumptions. Multicollinearity between the independent variables was not found to be a problem; therefore, no variables had to be omitted.

Exploratory factor analysis (EFA) was used as a data reduction technique to reduce the number of variables belonging to the perceptions of competitive strategy and the additional costs 
of standard adoption. Orthogonal (varimax) rotation was implemented in order to minimize the number of variables that have high loadings on each factor, allowing for factor solutions that are easier to interpret. Factors with latent root criteria (eigenvalues) greater than 1 were considered in this study, which means that each factor contributes to a greater variance than had been possible for any one of its variables. Concerning factor loadings, a minimum threshold of 0.4 was employed to determine the inter-correlation among the original variables. Factor analysis technique generates respondents' scores for each factor that can be used for subsequent multiple regressions (Hair et al. 2010). All statistical analyses were done using SPSS Statistics for Windows, Version 21.0.

\section{Results and discussions}

Descriptive statistics for the firm characteristics (independents) and the level of adopted food safety and quality systems (dependent) are presented in Table 1. All in all, 15 safety and quality assurance systems were taken into account in the questionnaire. Of these, 10 are qualityoriented systems such as Halal, PDO/PGI and organic standards, whereas the others are safetyoriented practices: BRC, Q\&S, IFS, HACCP and the Turkish food codex. 
Table 1: Adoption of food safety and quality systems and firm characteristics

\begin{tabular}{|c|c|c|c|c|}
\hline Dependent variable & Description & Maximum & Mean & $\begin{array}{l}\text { Std. devi- } \\
\text { ation }\end{array}$ \\
\hline $\begin{array}{l}\text { Level of adopted food safety } \\
\text { and quality standards }\end{array}$ & $\begin{array}{l}\text { Summed score of the total } \\
\text { adopted standards }(0-15)\end{array}$ & 10 & 3.54 & 2.21 \\
\hline Independent variables & Category & Base & Mean & $\begin{array}{c}\text { Std. devi- } \\
\text { ation }\end{array}$ \\
\hline $\begin{array}{l}\text { Ownership and control } \\
\text { Legal form of ownership }^{\text {a }}\end{array}$ & $\begin{array}{l}\text { Joint stock } \\
\text { Other }\end{array}$ & Limited & $\begin{array}{l}0.42 \\
0.12\end{array}$ & $\begin{array}{l}0.495 \\
0.330\end{array}$ \\
\hline Region $^{\text {a }}$ & $\begin{array}{c}\text { Marmara } \\
\text { Aegean } \\
\text { Other } \\
\text { Multiregional }\end{array}$ & Central Anatolia & $\begin{array}{c}0.07 \\
0.1 \\
0.06 \\
0.10\end{array}$ & $\begin{array}{l}0.250 \\
0.213 \\
0.232 \\
0.306\end{array}$ \\
\hline Family control ${ }^{\mathrm{a}}$ & - & - & 0.61 & 0.489 \\
\hline $\begin{array}{l}\text { Internationalization } \\
\text { Business abroad }^{\mathrm{a}}\end{array}$ & - & - & 0.71 & 0.457 \\
\hline Prevailing market served ${ }^{\mathrm{a}}$ & $\begin{array}{c}\text { Domestic market } \\
\text { EU } \\
\text { Middle and East Europe and } \\
\text { Russia } \\
\text { Asia } \\
\text { MENA }\end{array}$ & Multiple orientation & $\begin{array}{l}0.39 \\
0.04 \\
0.02 \\
0.04 \\
0.10\end{array}$ & $\begin{array}{l}0.489 \\
0.191 \\
0.137 \\
0.191 \\
0.306\end{array}$ \\
\hline Share of foreign market sales & $\begin{array}{c}\text { Dummy: } 0 \text { Less than } 50 \% \\
1 \text { More than } 50 \%\end{array}$ & - & 0.21 & 0.407 \\
\hline $\begin{array}{l}\text { Complexity } \\
\text { Firm size }^{\mathrm{a}}\end{array}$ & $\begin{array}{c}\text { Large: }>100 \text { employees } \\
\text { Medium: } 51-100 \text { employees }\end{array}$ & Small: 4-50 employees & $\begin{array}{l}0.26 \\
0.22\end{array}$ & $\begin{array}{l}0.443 \\
0.414\end{array}$ \\
\hline Subsector ${ }^{a}$ & $\begin{array}{c}\text { Meat and animal production } \\
\text { Fruits and vegetables } \\
\text { Dairy } \\
\text { Cereals } \\
\text { Other } \\
\text { Multi-production }\end{array}$ & Pastry & $\begin{array}{l}0.08 \\
0.03 \\
0.02 \\
0.04 \\
0.20 \\
0.21\end{array}$ & $\begin{array}{l}0.265 \\
0.167 \\
0.137 \\
0.191 \\
0.400 \\
0.407\end{array}$ \\
\hline Processed food share & Ten-Point Likert scale & - & 4.14 & 3.220 \\
\hline
\end{tabular}

Firm characteristics were regressed against the adoption intensity of food safety and quality standards. The model presented in Table 2 is statistically highly significant ( $1 \%$ level). This indicates that the model has a significant explanatory power and the variables included in the equation offer useful insights into the adoption decision of Turkish agribusiness firms. The goodness of fit of the multiple regression model represented by Adjusted R squared $\left(R_{a d j}^{2}\right)$ was 0.511 , which is a quite good value for social science research. 
Table 2: Multiple regression for firm characteristics and the number of standards adopted $(\mathrm{n}=106)$

\begin{tabular}{lc}
\hline Firm characteristics & Number of standards adopted \\
\hline Business abroad & $0.40^{* * *}$ \\
Large size $>100$ employees & $0.32^{* * *}$ \\
Aegean & $0.21^{* *}$ \\
Multiregional & $0.18^{*}$ \\
Joint stock & $0.22^{* *}$ \\
MENA & $-0.15^{* *}$ \\
$R_{\text {adj }}^{2}$ & 0.511 \\
F-statistic & $17.908^{* * *}$ \\
\hline${ }^{a}$ Variables and models significant at $\mathrm{P}^{*} \leq 0.05, \mathrm{P}^{* *} \leq 0.01$ and $\mathrm{P}^{* * *} \leq 0.001$ \\
Source: Survey data
\end{tabular}

Taking a closer look at the estimation results (Table 2), it becomes obvious that access to foreign market has a positive influence on firms' concern with food safety and quality standards. Similarly, Gawron and Theuvsen (2009) found that high numbers of certified companies in Central and Eastern European countries coincide with high exports. They concluded that in Turkey, Poland, Hungary and the Czech Republic, successful export of agricultural and food products was strongly fostered by the wide proliferation of quality certificates. This trend can be attributed to the attempt by export-oriented firms to meet the legal requirements and customer demands in foreign markets, which are considered major drivers behind the adoption of food safety and quality schemes in the food industry. This interpretation is supported by similar results from North America. A study by Jayasinghe-Mudalige and Henson (2007) revealed that suppliers in North America were interested in specific food safety controls to cope with the demands of supermarket chains and food service operators. Zhou and Jin (2009) also concluded that the probability of adoption increases when the destination market is a foreign market.

However, the results reported in Table 2 indicate that, if the MENA region was the major foreign market served, exporters were less likely to adopt more standards. The orientation of food processors toward MENA markets was inversely related to the number of standards adopted by a firm at a $1 \%$ level of significance.Therefore, being an exporter is not the only determinant in such a context, but the requirements of foreign market destinations obviously also play a decisive role. In developing countries and transformational economies in the MENA region, firms and consumers still have a lower level of awareness of food quality and safety standards. Many factors could contribute to this fact in MENA countries. High dependency on food imports, strong population growth, high unemployment rates, poverty and malnutrition elevate food security aspects to a higher concern than food safety and quality (Al Sultan 2010; IFPRI 2010). Additionally, the costs of compliance with a certain safety and quality standard are higher for small pro- 
ducers and processors, which dominate in MENA countries, particularly with the inability to get a price premium or attract customers by labeling for such standards.

The empirical results also indicate that adoption intensity is positively and significantly (at a $1 \%$ level of significance) associated with firm size as represented by number of employees. This implies the higher willingness of larger producers to implement higher levels of food safety and quality practices. This observation is congruent with previous findings (Ollinger et al. 2004; Jayasinghe-Mudalige and Henson 2007; Handschuch et al. 2013) which argued that larger firms have a higher capacity to implement food safety controls, while most small firms showed no desire to do so. Plausible reasons that explain why firm size has a more pronounced effect in the adoption decision can be summarized by three main points: economies of size in food safety control, greater customer pressure and being an exporter (Herath et al. 2007). The subsequent analysis of firm characteristic-related factors will show whether small firms' perceptions of additional costs affect their adoption behavior.

The empirical results provide some evidence related to the legal form of firm ownership. Compared with limited firms, there is a higher probability that joint stock companies adopt food safety and quality practices. The larger size and greater financial capacity of joint stock firms may enhance their ability to comply with more certification schemes. The new Turkish Trade Law (TTK, No. 6102 by 13.01.2011) limits the number of partners to 50 persons, whereas there is no limitation on the number of owners of joint stock companies. Furthermore, the threshold of establishment capital was fixed at 50,000 Turkish Lira (TL) plus 100,000 TL as the minimum registered capital. These requirements concerning equity capital are much lower for limited enterprises $(10,000 \mathrm{TL})$. Going public by issuing bonds is possible for joint stock companies, but not for limited ones (Official Gazette 2011).

Food enterprises operating in several regions in Turkey seem to be more interested in food quality and safety schemes since these firms tend to be larger. Firms with multiple regions of ownership and control are also often among those firms with a high degree of growth and a strong reputation. A high number of standards are of core importance for such companies. Unsurprisingly, the relationship between firm location in the Aegean region and the summed score of adopted schemes is positive, at a $1 \%$ level of significance. The higher interest of Aegean food companies in certified products can be attributed to the differentiation of agricultural production and processing between Turkish regions. The Aegean region is well known for producing, processing and exporting Mediterranean fruits, particularly figs, olives/olive oils and apricots (Işın 
et al. 2007; Koç et al. 2011). In 2012, for instance, Turkey ranked first in the world for fig production (24\% of world production) and first in the export of dried figs (63\% of world export) (FAOSTAT 2012). To maintain this leadership, Aegean food enterprises have made greater efforts to meet the food safety and quality regulations of the importers, for example EU Regulations 2002/80/EC and 2002/679/EC, which require a health certificate for dried fruits from Turkey, and Regulation 2007/459/EC, which requires fig exporters to obtain an aflatoxin certificate (Atici 2013).

It is worth mentioning that the common trend in the meat and dairy industries towards more intensive food safety approaches is not reflected in the empirical results. Similarly, Çobanoğlu et al. (2013) did not find a pronounced effect of subsectors on HACCP and ISO adoption in Turkish food enterprises. Currently, Turkish processed food products of animal origin are controlled by strictly regulated schemes (Demirbas and Karagözlu 2006). Certain schemes must be engaged throughout all processing and distribution steps of the supply chain. A farm-to-fork approach, for instance, that requires monitoring and auditing is compulsory in the chain from farm to fork (Demirbas et al. 2008). The trivial role of subsector in our results may be due to insufficient governmental intervention, which particularly differentiates among the agroindustry subsectors concerning food safety practices for non-exporting enterprises. Similarly, state agencies' lack of control over raw milk quality and animal health and the inadequate regulations concerning food safety were found to be major food safety problems in milk collection centers in Turkey (Demirbas et al. 2008).

Applying exploratory factor analysis on the statements regarding perceptions of additional costs resulted in two factors (Table 3). A total variance explained of $68.59 \%$ is considered satisfactory in the social sciences (Hair et al. 2010). These factors can be categorized as establishment costs and supplementary costs. Establishment costs have high loadings for the costs of calibration, maintenance, laboratory, infrastructure, and cleanliness and disinfection. Supplementary costs have high loadings for the costs of record keeping, employee training and management. 
Table 3: Varimax rotated factor loadings of additional cost statements

\begin{tabular}{lcc}
\hline \multirow{2}{*}{ Additional cost } & \multicolumn{1}{c}{ Factors } \\
\cline { 2 - 3 } & Establishment cost & Supplementary cost \\
\hline Calibration cost & $\mathbf{0 . 8 8 9}$ & 0.151 \\
Maintenance cost & $\mathbf{0 . 8 2 7}$ & 0.315 \\
Laboratory and analysis cost & $\mathbf{0 . 8 1 2}$ & 0.189 \\
Infrastructure and building renovation & $\mathbf{0 . 7 7 7}$ & 0.278 \\
Cleaning workers & $\mathbf{0 . 6 2 2}$ & 0.386 \\
Documentation requirements & 0.122 & $\mathbf{0 . 8 9 8}$ \\
Employee training & 0.266 & $\mathbf{0 . 7 5 5}$ \\
Change in management & 0.342 & $\mathbf{0 . 6 3 3}$ \\
Eigenvalues & 4.38 & 1.11 \\
Per cent of total variance explained & 41.59 & 27.00 \\
Cumulative per cent of the variance explained & 41.59 & 68.59 \\
Cronbach's alpha & 0.89 & 0.72 \\
Number of variables & 5 & 3 \\
\hline
\end{tabular}

${ }^{\mathrm{a}}$ Factors 1 and 2 are. Factor loadings $>|0.40|$ are in bold, KMO: 0,818

Source: Survey data

The statements related to competitive strategy were reduced to two factors by applying factor analysis (Table 4), with a total variance explained of $64.4 \%$. The two factors can be described as hybrid strategy and differentiation strategy. Hybrid strategy involves high loadings for competitive advantages such as innovative marketing, low procurement costs, offering low prices, ensuring the efficiency of business processes and communicating brand and company reputation. Differentiation strategy is characterized by serving niche markets, quality and innovation leadership and leadership with regard to market innovations.

Table 4: Varimax rotated factor loadings of competitive strategy statements

\begin{tabular}{lcc}
\hline \multirow{2}{*}{ Competitive strategy } & \multicolumn{2}{c}{ Factors } \\
\cline { 2 - 3 } & Hybrid & differentiation \\
\hline Innovative marketing & $\mathbf{0 . 8 1 3}$ & 0.167 \\
Low procurement costs & $\mathbf{0 . 7 8 6}$ & 0.230 \\
Communicating brand and company reputation & $\mathbf{0 . 7 3 2}$ & 0.322 \\
Ensuring efficiency of business processes & $\mathbf{0 . 7 3 0}$ & 0.145 \\
Offering low prices & $\mathbf{0 . 6 0 2}$ & 0.269 \\
On international markets, we serve niche markets. & 0.114 & $\mathbf{0 . 9 3 0}$ \\
On international markets we, compete on quality and innovation leadership. & 0.012 & $\mathbf{0 . 8 6 6}$ \\
We are usually ahead of our competitors with new products on the market. & 0.363 & $\mathbf{0 . 6 3 7}$ \\
Eigenvalues & 3.47 & 1.69 \\
Percent of total variance explained & 35.67 & 28.73 \\
Cumulative percent of the variance explained & 35.67 & 64.40 \\
Cronbach's alpha & 0.78 & 0.78 \\
Number of variables & 5 & 3 \\
\hline
\end{tabular}

${ }^{\mathrm{a}}$ Factors 1 and 2 are agriculture. Factor loadings $>|0.40|$ are in bold, KMO: 0.745

Source: Survey data

After obtaining insights into the role of firm characteristics with regard to adoption of food safety and quality standards, the contribution of subjective factors was identified. Respond- 
ents' perceptions of additional costs, competitive strategy (represented by respondent's scores for each factor) and EU requirements were added to the firm characteristics in the regressions analysis. Hair et al. (2010) indicated that the adjusted $R^{2}$ value is particularly useful in making comparisons across regression equations involving different numbers of independent variables. The statistical output showed a lower adjusted $R^{2}$ value $(0.482)$ for the second model than for the first model (0.511). Furthermore, firm characteristic-related factors were not statistically significant. The decrease in the adjusted $R^{2}$ when adding these factors indicates an overfitting of the data; moreover, the addition of variables does not contribute significantly to predictive accuracy (Hair et al. 2010).

Implementing food quality and safety standards is expected to be a financial burden. However, the regression model indicated that the perception of additional costs did not affect the implementation decision. This could be ascribed to the higher expected benefits of such standards compared with required costs. Holleran et al. (1999) argued that the utilization of standards is worthwhile if the benefits of the quality assurance system exceed the adoption and maintenance costs. Similarly, Gawron and Theuvsen (2006) found that the cost of quality assurance in the food sector rises due to high unnecessary double-checks, particularly in the case of supplying to several retailers. Schulze et al. (2008) found that it was not the cost of certification per se but the perceived cost-benefit ratio that is decisive for firms' willingness to adopt standards. On the other hand, food quality and safety standards provide neutral instruments based on third-party audits that can improve quality and decrease costs at the same time, through such factors as waste reduction, improved business processes and lower numbers of product recalls (Heyder et al. 2012). In correspondence with the statistically insignificant role of the perception of additional costs, perceptions of EU requirements and competitive strategy turned out not to affect the implementation level of food safety and quality systems.

\section{Conclusions, implications and future research}

Empirical analysis was done in order to investigate the impact of firm characteristics and perception of related factors on the adoption of food safety and quality practices. From our questionnaire-based survey, we obtained these impacts for a group of Turkish agribusiness firms. In general, the adoption of food safety and quality assurance practices was found to be very closely linked to objective data characterizing Turkish food processors, whereas subjective perceptions turned out to be insignificant. With regard to firm characteristics, the results showed that the le- 
gal form of ownership, region of ownership and control, firm size, being an exporter and major market served have a greater influence than industry subsector, level of foreign market sales and processed food share. Several specific inferences can be drawn from the results.

First, our findings have interesting managerial implications. The insights derived from the questionnaire-based survey allow managers in Turkish food processing companies to evaluate their firm characteristics and adoption practices. In this sense, the empirical study provides a starting point for benchmarking activities through which agri-food firms can assess the strengths and weaknesses of their food quality and safety strategies.

Furthermore, our study found that larger enterprises with more than 100 employees are more interested in implementing food safety and quality standards. Moreover, smaller firms do not perceive high additional per unit costs associated with implementation procedures. This indicates that there should be an increased focus on food quality and safety systems in smaller sized firms since this could provide greater social benefits at comparatively low implementation costs. Consequently, further research focusing on cost-benefit analyses of standards could provide additional useful insights into such a context. Herat et al. introduced another point of view: "Synergies associated with enhanced food safety and quality controls for large firms in maintaining customer satisfaction may be the essential driver. Therefore, policy directives to improve the technical adequacy of firms to meet food safety goals must at the same time accommodate and address the important synergies involved in enhancing food quality attributes, at least in the context of larger food processing establishments" (2007, p. 311). Our findings suggest that this view regarding synergies should be expanded to include smaller firms.

Our research also provides new evidence on the relationship between a firm's market orientation and internationalization strategy and the utilization of food safety and quality assurance practices. Being an exporter is positively related to the utilization of food quality and safety standards; this result complies with earlier findings. However, the exporters concerned primarily with MENA markets were less interested in certification and other standards. Obviously there is a need to more clearly distinguish between the markets served when analyzing the relationship between exports and certification. Since Turkey has become a regional supply center for the MENA region (ISPAT 2014), further research should try to determine how the MENA markets influence the adoption of food safety schemes in the Turkish food industry. Out finding also provides a starting point for more general research into the governance of food supply chains that do not address the advanced markets of industrialized countries. 
Our empirical results revealed a statistically insignificant relationship between the respondents' perceptions of EU requirements and the firms' behavior towards utilization of food safety and quality assurance systems. Prior studies have mainly focused on the explanation of EU regulations and requirements. Furthermore, no attention has been paid to producers' and processors' perceptions of such requirements, which should also be analyzed more thoroughly. All in all, the implementation of certification systems and other food quality and safety systems has become a strong trend in Turkish agribusiness. Future research taking into account the impact of this trend on such economic performance indicators as profitability, multifactor productivity, costs and reputation will provide insights into further developments in this area.

\section{Bibliography}

Alpay, S., Dabour, N.M., Aydin, A.S., Tintin, C., Ünal, U., Bağci, K., Korbayram, A. and Hussain, M. (2013). State of agriculture and food security in OIC member countries: Opportunities for cooperation. SESRIC. Statistical, Economic and Social Research and Training Center for Islamic Countries. Oran, Ankara.

Al Sultan, F. (2010). Ensuring food security and food safety at the global level and MENA region. International Food Policy Research Institute (IFPRI). Ministerial Summit and Inauguration of SIAL Middle East and the $4^{\text {th }}$ International Date Palm Festival, Abu Dhabi, November 23, 2010.

Anders, S.M. and Caswell, J.A. (2009). Standards as barriers versus standards as catalysts: Assessing the impact of HACCP implementation on US seafood imports. American Journal of Agricultural Economics, 91(2), 310-321.

Antle, J.M. (1995). Choice and efficiency in food safety policy. The AEI Press, Washington, DC.

Artik, N. (2013). The report of Turkish food and drink industry. TÜGİS. Turkish Food and Beverage Industry Employers Association. Galatasaray, Istanbul.

Atici, C. (2013). Food Safety Regulations and Export Responses of Developing Countries: The Case of Turkey's Fig and Hazelnut Exports. FAO commodity and trade policy research, working paper 39, Rome. 
Baş, M., Ersun, A.Ş. and Kıvanç, G. (2006). Implementation of HACCP and prerequisite programs in food businesses in Turkey. Food Control, 17(2), 118-126.

Baş, M., Yüksel, M. and Çavuşoğlu, T. (2007). Difficulties and barriers for the implementing of HACCP and food safety systems in food businesses in Turkey. Food Control, 18(2), 124-130.

Buzby, J.C. and Frenzen, P.D. (1999). Food safety and product liability. Food Policy, 24(6), 637651.

Cakmak, E.H. and Dudu, H. (2013). Economic Growth in the Euro-Med Area through Trade Integration: Focus on Agriculture and Food: The Case Study of Turkey. European Commission, Joint Research Centre, Institute for Prospective Technological Studies, JRC Scientific and Technical Reports, Report EUR 26532 EN. Seville.

Caswell, J.A., Bredahl, M.E. and Hooker, N.H. (1998). How quality management metasystems are affecting the food industry. Review of Agricultural Economics, 20(2), 547-557.

CBI. Ministry of Foreign Affairs of the Netherlands. (2010). EU legislation: Hygiene of food (HACCP). The Hague.

Chiciudean, G.O., Ilea, M. and Chiciudean, D. (2014). Traditional food products certification in Romania and the European Union. Lucrări Științifice Management Agricol, 16(2), 119-122.

Çobanoğlu, F. and Işın, F. (2007). Adoption of some food safety systems in Turkish fig businesses. In: Çobanoğlu, F. (Ed.). A research on the applicability of some quality safety systems in dried and fresh fig production, domestic and foreign marketing in Turkey. Ph.D thesis, Aegean University, Izmir.

Çobanoğlu, F. (2012). Is export orientation a major motivator for the adoption of food safety systems in the Turkish dried fig firms? Journal of Agriculture and Rural Development in the Tropics and Subtropics, 113(1), 31-42.

Çobanoğlu, F., Karaman, A.D. and Tunalioglu, R. (2013). Critical evaluation for adoption of food safety systems in the Turkish dairy and meat processing businesses. Journal of Agricultural Science and Technology, 15(1), 101-114. 
Demirbas, N. and Karagözlu, C. (2006). The problems of raw material supply of the Turkish dairy industry and suggestions: The case of Izmir. Agricultura Tropica et Subtropica, 39(2), 110113.

Demirbas, N., Gölge, E., Tosun, D. and Cukur, F. (2008). Food safety practices in milk collection centers in Turkey: A case study. British Food Journal, 110(8), 781-789.

European Commission. (2013). Turkey 2013 progress report. Commission staff working document, accompanying the document: Communication from the Commission to the European Parliament and the Council, enlargement strategy and main challenges 2013-2014, Brussels, 16.10.2013, SWD(2013) 417 final. URL: http://ec.europa.eu/enlargement/pdf/key_documents/ 2013/package/brochures/turkey_2013.pdf. Accessed: 28.08.2014.

FAO. Food and Agriculture Organization of the United Nations (2012): Eastern Europe and Central Asia agro-industry development country brief Turkey, Regional Office for Europe and Central Asia. URL: http://www.fao.org/fileadmin/user_upload/Europe/documents/Publications/ AI_briefs/AI_breiefs2012/fao_turkey.pdf. Accessed: 01.09.2014.

FAOSTAT (2012). Agricultural statistics database. http://faostat.fao.org.

Fellmann, T., van Leeuwen, M. and Salamon, P. (2011). EU enlargement to Turkey: Potential impacts on agricultural markets and how they are shaped by changes in macroeconomic conditions. German Association of Agricultural Economists (GEWISOLA), 51st Annual Conference, Halle, Germany, September 28-30, 2011 (No. 114507).

Fouayzi, H., Caswell, J.A. and Hooker, N.H. (2006). Motivations of fresh-cut produce firms to implement quality management systems. Applied Economic Perspectives and Policy, 28 (1), $132-146$.

Gawron, J.-C. and Theuvsen, L. (2006). The international food standard: Bureaucratic burden or helpful management instrument in global markets? Empirical results from the German food industry. Paper presented at $98^{\text {th }}$ EAAE Seminar 'Marketing Dynamics within the Global Trading System: New Perspectives', Chania, Crete, 29 June - 2 July 2006. 
Gawron, J.-C. and Theuvsen, L. (2009). Certification schemes in Central and Eastern Europe: a Status quo Analysis in the Agrifood Sector. Polish Journal of Food and Nutrition Sciences, $59(1), 5-10$.

Golan, E., Roberts, T. and Ollinger, M. (2004). Savvy buyers spur food safety innovations in meat processing. Amber Waves, 2 (2), 23-29.

Hair, Jr. F., Black, W. C., Babin, B. J. and Anderson, R. E. (2010). Multivariate data analysis. 7th Edition. Pearson Prentice Hall, New Jersey.

Handschuch, C., Wollni, M. and Villalobos, P. (2013). Adoption of food safety and quality standards among Chilean raspberry producers: Do smallholders benefit? Food Policy, 40 (1), 6473.

Hassan, Z., Green, R. and Herath, D. (2006). An empirical analysis of the adoption of food safety and quality practices in the Canadian food processing industry. In: M. Holt and J. Chavas. (Eds.): Essays in Honor of Stanley R. Johnson. Berkeley Electronic Press, Berkeley, CA, 1-23.

Henson, S. and Holt, G. (2000). Exploring incentives for the adoption of food safety controls: HACCP implementation in the UK dairy sector. Review of Agricultural Economics, 22 (2), 407 420.

Henson, S. and Blandon, J. (2007). The Impact of Food Safety Standards on Export-Oriented Supply Chains: Case of the Horticultural Sector in Guatemala. Economic Commission for Latin America and the Caribbean (ECLAC). Guelph, Canada.

Herath, D., Hassan, Z. and Henson, S. (2007). Adoption of food safety and quality controls: do firm characteristics matter? Evidence from the Canadian food processing sector. Canadian Journal of Agricultural Economics/Revue canadienne d'agroeconomie, 55 (3), 299-314.

Heyder, M., Hollmann-Hespos, T. and Theuvsen, L. (2012). Investments in Tracking and Tracing Systems in the Food Industry: A PLS Analysis. Food Policy, 37, 102-113.

Hobbs, J.E., Fearne, A. and Spriggs, J. (2002). Incentive structures for food safety and quality assurance: An international comparison. Food Control, 13 (2), 77-81. 
Holleran, E., Bredahl, M.E. and Zaibet, L. (1999). Private incentives for adopting food safety and quality assurance. Food Policy, 24 (6), 669-683.

Huff, H.B. and Owen, C.J. (1999). The Canadian food regulatory system: Responding to pressures for change. Canadian Journal of Agricultural Economics/Revue Canadienne d'Agroeconomie, 47 (4), 387-396.

IFPRI. International Food Policy Research Institute. (2014). Middle East and North Africa Strategy. Washington, DC.

Işın, F., Cukur, T. and Armagan, G. (2007). Factors affecting the adoption of the organic dried fig agriculture system in Turkey. Applied Sciences, 7 (5), 748-754.

ISPAT. Investment Support and Promotion Agency of Turkey. (2014). Food and Agriculture in Turkey. Çankaya, Ankara.

Jayasinghe-Mudalige, U. and Henson, S. (2007). Identifying economic incentives for Canadian red meat and poultry processing enterprises to adopt enhanced food safety controls. Food Control, 18 (11), 1363-1371.

Keenan, S., Hammond, J., Leeks, D. and Misiova, I. (2011). Food safety and public health situation in Turkey. ENVI delegation to Turkey (2-4 November 2011), Director General for Internal Policies, Director A: Economic and Scientific Policy. European Parliament. URL: http://www.europarl.europa.eu/document/activities/cont/201111/20111111ATT31265/20111111 ATT31265EN.pdf. Accessed: 06.02.2013.

Klein, B. and Leffler, K.B. (1981). The role of market forces in assuring contractual performance. Journal of Political Economy, 89 (4), 615-641.

Koç, A.A., Asci, S., Alpas, H., Giray, F.H. and Gay, S.H. (2010). Food quality and safety situation in Turkey: Governance and barriers to success. Food Economics: Acta Agricult Scand C, 7 (2-4), 245-259.

Koç, A.A., Asci, S., Alpas, H., Giray, F.H. and Gay, S.H. (2011). Food quality assurance schemes in Turkey. European Commission, Joint Research Centre, Institute for Prospective Technological Studies, JRC Scientific and Technical Reports, Report EUR 24672 EN - 2011. 
Leible, S., Ortgies, F. and Schaefer, S. (2014). Principles of food law. In: Petersen, B. Nuessel, M. and Hamer, M. (Eds.): Quality and risk management in agri-food chains. Wageningen Academic Publishers, Wageningen, 48-50.

Lindgreen, A. and Hingley, M. (2003). The impact of food safety and animal welfare policies on supply chain management: The case of the Tesco meat supply chain. British Food Journal, 105 (6), 328-349.

Luning, P.A., Marcelis, W.J. and Jongen, W.M.F. (2002). Food quality management: A technomanagerial approach. Wageningen Pers, Wageningen.

MacDonald, J.M. and Crutchfield, S. (1996). Modeling the costs of food safety regulation. American Journal of Agricultural Economics, 78 (5), 1285-1290.

MacDonald, J.M., Ollinger, M.E., Nelson, K.E. and Handy, C.R. (1996). Structural change in meat industries: Implications for food safety regulation. American Journal of Agricultural Economics, 78 (3), 780-785.

Madlener, R. and Wickart, M. (2004). Diffusion of cogeneration in Swiss industries: economics, technical change, field of application, and framework conditions. Energy \& Environment, 15 (2), 223-237.

Mensah, L.D. and Julien, D. (2011). Implementation of food safety management systems in the UK. Food Control, 22 (8), 1216-1225.

Meuwissen, M.P.M., Velthuis, A.G.J., Hogeveen, H. and Huirne, R.B.M. (2003.Traceability and certification in meat supply chains. Journal of Agribusiness, 21 (2), 167-181.

MFAL. Ministry of Food, Agriculture and Livestock. (2014). Food and Feed Service, Laboratories, Ankara. URL: http://www.tarim.gov.tr/Konular/Gida-Ve-Yem-Hizmetleri/Laboratuvarlar. Accessed: 29.09.2014.

Mutlu, S., Bal, T., Say, D. and Emeksiz, F. (2003). The adoption and implementation of the food quality system (HACCP) in Mediterranean Region of Turkey. In: Nikolaidis, A., Baourakis, G., Isikli, E. and Yercan, M. (Eds.). The market for organic products in the Mediterranean region. CIHEAM, Cahiers Options Méditerranéennes, Chania, 61, 201-217. 
Official Gazette (2010). TÜRK TİCARET KANUNU No. 27610, 13.06.2010. URL: http://www.resmigazete.gov.tr/main.aspx?home=http://www.resmigazete.gov.tr/eskiler/2010/06/ 20100613.htm\&main=http://www.resmigazete.gov.tr/eskiler/2010/06/20100613.htm. Accessed: 26.09.2013.

Official Gazette (2011). TÜRK TİCARET KANUNU No. 27846, 14.02.2011. URL: http://www.resmigazete.gov.tr/eskiler/2011/02/20110214-1-1.htm. Accessed: 26.09.2013.

Official Gazette (2013). TÜRK TİCARET KANUNU No. 28710, 17.07.2013. URL: http://www.resmigazete.gov.tr/main.aspx?home=http://www.resmigazete.gov.tr/eskiler/2013/07/ 20130717.htm\&main=http://www.resmigazete.gov.tr/eskiler/2013/07/20130717.htm. Accessed: 27.09.2013.

Ollinger, M.E., Moore, D. and Chandran, R. (2004). Meat and Poultry Plant's Food Safety Investments: Survey Findings. Technical Bulletin No. 1911. United States Department of Agriculture, Economics Research Service, Washington, DC.

One World (2014). Nations Online. Nationsonline.org. URL: http://www.nationsonline.org/oneworld/. Accessed: 27.09.2013.

Schulze, B., Spiller, A. and Theuvsen, L. (2006). More trust instead of more vertical integration in German pork production? Empirical evidence and theoretical considerations. In: Fritz, M., Schiefer, G. and Rickert, U. (Eds.). Trust and risk in business networks, ILB-Press, Bonn, 373382.

Schulze, H., Albersmeier, F., Gawron, J.-C., Spiller, A, and Theuvsen, L. (2008). Heterogeneity in the evaluation of quality assurance schemes: The International Food Standard (IFS) in European agribusiness. International Food and Agribusiness Management Review, 11(3), 99-139.

Sözen, B.U. and Hecer, C. (2013). Is HACCP a difficult food safety system to implement? Journal of Biological and Environmental Sciences, 7 (19), 33-38.

Thomsen, M.R. and McKenzie, A.M. (2001). Market incentives for safe foods: An examination of shareholder losses from meat and poultry recalls. American Journal of Agricultural Economics, 83 (3), 526-538. 
Turner, C.R., Ortmann, G.F. and Lyne, M.C. (2000). Adoption of ISO 9000 quality assurance standards by South African agribusiness firms. Agribusiness, 16 (3), 295-307.

Woteki, C. (2000). USDA Research Needs in Food Safety. Eds. In: Unnevehr, L. (Ed.). The economics of HACCP: Costs and benefits. Eagan Press, St. Paul.

Zhou, J. and Jin, S. (2009). Adoption of food safety and quality standards by China's agricultural cooperatives: A way out of monitoring production practices of numerous small-scale farmers. International Association of Agricultural Economists Conference, August 16-22, 2009, Beijing. 
Teil III: EU requirements for food safety and quality systems:

Determinants of perceptions

Tuba Pekkirbizli, Mohamad Isam Almadani and Ludwig Theuvsen

Vorgesehen zur Einreichung beim

Journal of Agribusiness 


\title{
EU requirements for food safety and quality systems: Determinants of perceptions
}

\author{
Tuba Pekkirbizli, Mohamad Isam Almadani and Ludwig Theuvsen
}

Georg-August University, Department of Agricultural Economics and Rural Development, Göttingen, Germany

\begin{abstract}
With Turkey seeking EU accession, a series of reform packages are to be implemented to fulfill the membership requirements. A large number of Turkish agri-food processors, however, are still unable to produce in accordance with the EU specifications. Furthermore, Turkish food producers' perceptions of the EU regulations are still unverified. Based on knowledge and on personal and economic perspectives, this paper assesses how operators in the Turkish agri-food industry perceive the EU requirements on their businesses. The results indicate that those perceptions vary widely among the processors depending on their education level, firm size, and legal form of ownership. Moreover, the subjective information related to the perceptions of the advantages, requirements and costs of food safety and quality practices significantly contribute to the perceptions examined. The findings have manifold implications which should be taken into account when adapting Turkish legislation to reflect EU regulations.
\end{abstract}

Keywords: Turkey, food safety and quality, the EU requirement, perceptions

\section{Introduction}

Turkish agriculture is a key sector in both social and economic terms. In 2013, it represented $8.9 \%$ of national GDP and formed $23.6 \%$ of the country's labor force (IPA II 2014). Due to the various agricultural resources and ecological conditions, a young and dynamic population and the country's favorable geographical location in the world, Turkey is a major world producer and exporter of many agricultural products (e.g. fruits, vegetables and nuts) (Alpay et al. 2013; Fellmann et al. 2011). The agricultural industry in Turkey has improved rapidly during the last few years. It is a major contributor to the country's GDP, exports and industrial growth (Keenan et al. 2011). The effective performance of Turkish agro-industries and their export-oriented strat- 
egies have resulted in a positive net trade from agribusiness (Cakmak and Dudu 2013). In the context of agribusiness, the European Union (EU) is by far Turkey's most important trading partner; $45 \%$ of Turkish exports are destined for EU-27 countries. Approximately $38 \%$ of total Turkish trade and $71.3 \%$ of foreign direct investments in 2012 are destined for EU-27 countries (IPA II 2014). The presence of a large variety of Turkish food products may contribute to the country's attractiveness for EU tourists. Moreover, the number of Turkish citizens in the EU is another incentive for Turkish food products to enter the EU market (Koç et al. 2010).

Since the 1963 Ankara Association Agreement, Turkey has been given preferential trade status by the EU with reduced import tariffs, the adoption of parts of the EU regulatory body (the so-called acquis communautaire) and provision for the gradual creation of a tariff union. Turkey also submitted its application for EU membership in 1987. The country was accepted as an eligible candidate for EU membership at the Helsinki Summit in December 1999 and began its negotiation process for membership in October 2005 (Antonucci and Manzocchi 2006; Akşit and Üstün 2009). With Turkey seeking EU accession, a series of reform packages were developed to fulfill the membership requirements (Akşit and Üstün 2009). However, despite these efforts, the process of harmonizing Turkish legislation with EU legislation is a slow one. For instance, food safety and quality assurance standards are not fully and effectively applied in the field, and many gaps still need to be filled in this regard (Koç et al. 2011; Çobanoğlu 2012; IPA II 2014). Koç et al. (2010) indicated that a high number of food producers in Turkey are not able to meet EU standards, particularly small enterprises. Therefore, a large share of Turkish operators cannot produce at the same quality level as their EU counterparts.

Recently, in order to qualify and/or quantify the barriers of Turkey's success to cope with EU requirements related to food safety and quality, many papers and reports have been produced. Such efforts can be divided into two categories: (1) analysis of the determinants of standard adoption and (2) evaluation of the effectiveness of measures for adapting to EU requirements. The determinants that may influence the adoption of food safety and quality assurance practices are discussed in order to enhance such practices in the Turkish food industry. Mutlu et al. (2003), Baş et al. (2006 and 2007) and Sözen and Hecer (2013) determined some indicators, difficulties and barriers related to hazard analysis critical control point (HACCP) implementation in the Turkish food business. Çobanoğlu (2012) explored whether export orientation motivates the adoption of food safety systems in Turkish dried fig firms. Demirbas et al. (2008) and Demirbas and Karagözlü (2008) investigated the main constraints in meeting food safety and quality requirements in the Turkish dairy industry in Izmir province. Kök (2009) determined the 
extent of food safety management systems (ISO 22000 and HACCP) implementation in the Turkish poultry industry. Çobanoğlu et al. (2013) identified factors that stimulate the implementation of food safety and quality assurance systems in the dairy and meat sectors.

Many papers and reports have sought to evaluate the effectiveness of certain measures in meeting EU requirements among food enterprises in Turkey. However, in most cases, these studies are technical reports rather than empirical analyses. Prominent examples are the European Commission working papers that annually evaluate performance in the area of food safety and veterinary and phytosanitary conditions in Turkey. Similarly, the European Parliament's Committee on the Environment, Public Health and Food Safety provides annual notes about the food safety situation in Turkey (Guittard 2006; Koletzko 2008; Keenan et al. 2011). Recently, an indicative strategy paper for Turkey was prepared by the European Commission in order to identify how Turkey's accession progress will be measured and monitored during the period 20142020 concerning all aspects of the accession requirements (IPA II 2014). Koç et al. (2010) evaluated the institutional environment for food quality and safety among producers of nine major products in twelve different regions in Turkey, including compliance with EU legislation. Garcia et al. (2004), van Berkum (2005) and Koç et al. (2011) analyzed the governance structure and performance of quality systems in the Turkish agri-food chain.

Despite diversified research in this field, firm operators' perceptions of EU requirements regarding food safety and quality regulations are still unverified. The evaluation of such perceptions can be considered an enhanced effort toward optimized coping with EU statutes in the Turkish food industry. This paper assesses how operators in the Turkish agri-food industry perceive their EU obligations, that is, whether they perceive the requirements as opportunities for advancement or as threats. Moreover, the study examines some objective and subjective factors that could cause these perceptions.

\section{Development of Turkey's progress against EU requirements}

The accession negotiations between the EU and Turkey are contained in an agreement developed by the European Commission containing 33 chapters. Chapter 12, which deals with food safety, veterinary and phytosanitary policy, reflects the EU's integrated approach, seeking to ensure a high level of food safety, animal health, animal welfare and plant health. In its 2006 screening report, the European Commission found it would be very hard for Turkey to adopt as Turkish legislation was far from compatible with the Community acquis (European Commission 
2007). The European Commission's 2006 screening meetings for Chapter 12 concluded that most of Turkey's checkpoints do not comply with EU requirements. The meetings' conclusion stated, "The size of the country, the dominance of small holdings and small scale food processing establishments in remote areas, the animal health situation of Turkey and certain cultural and religious traditions pose key challenges to the enlargement process in the area of food safety, veterinary and phytosanitary policy" .Indeed, it pointed out various elements in Turkish legislation that would not be compatible with the Community acquis within the framework of Chapter 12. These critical elements include traceability of animals, especially regarding epizootic diseases; hygiene requirements; and insufficient Turkish administration in both equipment and staff. Burrel (2008) indicated that the main challenges to Turkish membership in the EU in the agrifood domain are (1) adoption of the huge administrative burden of the acquis communautaire, (2) market integration and (3) managing the rapid structural changes that will follow. Effective implementation and enforcement of the agri-food acquis will take several years, not only where food safety and veterinary standards are concerned, but also in areas such as agri-environmental standards, cross compliance, animal registration, border inspection and controls.

Turkish laws have no comprehensive concepts regarding food, feed and veterinary areas, for instance with regard to food safety controls from 'farm to fork'; rather they keep these areas as separate regulations. Consequently, in the legislative field of food safety issues, a foundation for future alignment with EU rules has still not been adopted (Koletzko 2008; Koç et al. 2011). However, the infrastructure regarding food safety issues, such as the minimum legal requirements requested by the EU, other importing countries and multinational food retail chains have generally been improved in Turkey. Concerning the legislative reforms that it has to undergo, the 2010-2011 Action Plan issued by the Turkish Secretariat General for EU affairs provided detailed information about the reforms to be made. Furthermore, the Secretariat developed a strategy for the modernization of agri-food establishments to meet EU food safety standards, on the basis of which the Turkish Parliament passed Veterinarian Services, Crop Health, Food and Feed Law No. 5996, which was a prerequisite of Chapter 12. It also had to adopt a law establishing and outlining the duties of the Ministry of Food, Agriculture and Livestock (MFAL), thus providing for a single body that would be responsible for all the policies of the acquis chapter, as requested by the EU (Official Gazette 2010; Bidault 2012).

As a result of such reforms, observations show that there are notable quality improvements in various agri-food sectors in Turkey. For example, in milk production, milk quality exceeds the minimum Food Codex requirements. In this context, the European Commission's 
screening report of 2014 conducted that Turkey's legislative alignment and implementation have advanced on a number of issues, such as labelling, additives and purity criteria, flavorings and food supplements. Nevertheless, legislative reforms are far from being sufficient for Turkey to meet all the EU requirements, and further efforts must be implemented in this area. For instance, alignment in the area of food enzymes and novel foods has not yet been completed. In response to this situation, the commission concluded its last report with this statement: "Progress in the area of food safety, veterinary and phytosanitary policy has remained limited. Further substantial work is needed to advance on full implementation of the acquis in this area. Significant work is needed on upgrading agri-food establishments to meet EU standards, the identification and registration of animals, animal welfare, animal by-products and the fight against animal diseases. Overall, preparations in this area are at an early stage" (European Commission 2014, p. 35).

It appears that great progress has been achieved in Turkey in modifying legislation, regulations and inspections and in monitoring in the areas of food safety. In addition, industrial food producers in many food subsectors (e.g., dairy, fishery and poultry) seem to be achieving great improvement at the firm level by complying with the EU requirements (Koletzko 2008). Atici (2013) showed that the 2002 regulation of aflatoxin harmonization - one of the EU food safety regulations - positively influenced the volume of Turkish hazelnut exports to the EU. In order to enhance improvement procedures at the firm level, this study is not concerned with a general performance evaluation of legislative reforms in Turkey at the national level, but seeks to better understand the perception and, thus, implementation of such EU requirements at the firm level.

\section{Theoretical framework}

As mentioned before, EU regulations in the area of food safety and quality practices include various aspects, such as economic, technological and social requirements. Firm operators' perceptions of EU regulations are strongly influenced by the consequences these requirements may have for their firms. This study assesses whether these consequences are perceived as opportunities for advancement, as threats or even as invitations to catastrophe at the firm level. In other words, the research question is this: To what extent is coping with EU requirements viewed as risky behavior by managers in the Turkish food sector? Moreover, this study seeks to identify indicators of the general tendency of the operators' perceptions.

Wildavsky and Dake (1990) conducted the most comprehensive study of theories used to explain the decision-makers' perceptions of risks and opportunities. Their overview includes 
knowledge, personality, economic, political and cultural theories. Our study supposes three theories (knowledge, personality and economic) to be of major relevance when investigating perceptions of EU requirements among agri-food firms. Knowledge theory presumes that perception of danger from a given source is inversely related to how much individuals know about that source. A lack of knowledge, therefore, stimulates perceptions of risk. Obviously, individuals' knowledge is greatly affected by their personalities. People have different conceptions of the same event. Consequently, different behaviors will be exhibited if, for instance, a situation is regarded as too risky by one person but less risky or acceptable by another (Hillson and MurrayWebster 2004). These differences can be attributed to personality indicators such as education, age, occupation, goals and aspirations, which influence people's perceptions (Van Raaij 1981; Wilson et al. 1993). Economic theory also interprets producers' perceptions. For instance, economies of size simply suggest that large and export-oriented firms are more willing to take risks stemming from new technologies and applications because they benefit more and/or are somehow better shielded from adverse consequences, due to factors such as having "deeper pockets".

This study identifies many indicators related to the three theories explained above. As shown in the study design (Figure 1), knowledge and personality are assumed to be represented by objective information concerning age, gender, education and occupation. With regard to economic perspectives, some objective factors include firm size, market served and industry subsector. The study also supposes that perceptions of some matters related to food safety and quality standards may influence firm operators' assessments of EU requirements. Hence, subjective information related to operators' perceptions of advantages and disadvantages, inciters, additional costs and their firms' competitive strategies is embraced under economic perspectives. 


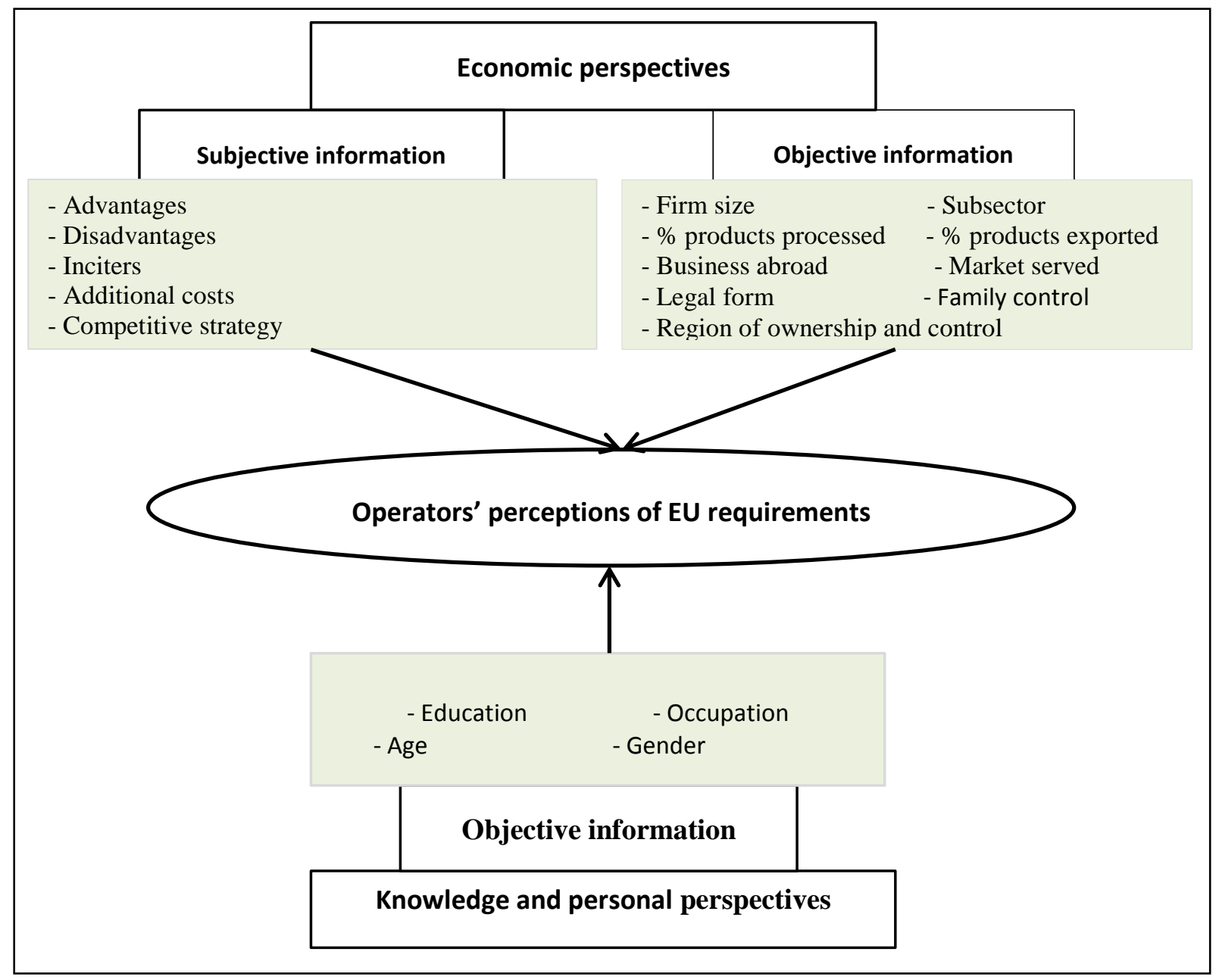

\section{Materials and methods}

The data were collected using a questionnaire-based survey in randomly selected agrifood enterprises in Turkey. The survey questionnaire comprised four major sections: (1) firm characteristics, (2) trade and marketing perspectives, (3) perceptions of food safety and quality systems, and (4) personal characteristics of firm operators. Closed questions (yes/no) were used to detect the firm and respondents' characteristics. Five-point Likert-scales $(1=$ strongly disagree to $5=$ strongly agree) were used to elicit respondents' perceptions of advantages, disadvantages, inciters, additional costs and their firms' competitive strategies. The questionnaire was mailed in June 2013 to 250 randomly selected food enterprises in Turkey. The sample included firms selected from the lists of addresses from OAIB Orta Anadolu İhracatçı Birlikleri (Central Anatolian Exporters Union). All in all, 199 enterprises returned the questionnaire. After screening for completeness, the questionnaires of 99 firms were available for statistical analysis. 
Descriptive analyses were carried out to examine the variability present within independent variables. To investigate producers' perceptions of EU requirements with regard to the food industry, an ordinal logistic regression model was employed. Since the choice of a model is largely determined by the scale of measurement of the response variable (Greenland 1985), ordinal logistic regression seems suitable for determining the affecting factors in operators' perception of EU regulations in agri-food firms. Perception of EU requirements was designed in the form of an ordinal variable (from 1=high-risk to $5=$ high-opportunity). The outcome variable is of interest in estimating the expected risks that could stem from EU regulations. Usually such information is analyzed using an ordinal logistic model rather than by creating dichotomy among the levels of predicted risks (risky or not risky). Compared to frequently used methods for binary and nominal data, ordinal regression models have the advantage that they make full use of ranked data (Lee 1992; Ananth and Kleinbaum 1997; Scott 1997).

Exploratory factor analysis (EFA) was used to reduce the number of variables in the subjective data. Orthogonal (varimax) rotation was implemented in order to minimize the number of variables with high loadings on each factor, with a minimum threshold of 0.4. Factors with latent root criteria (eigenvalues) greater than 1 were considered in this study. Factor analysis generates respondents' scores for each factor that can be used for the subsequent regression (Hair et al. 2010). All statistical analyses were done with SPSS Statistics for Windows, Version 21.0. 


\section{Results and discussions}

Table 1: Descriptive statistics for dependent and independent variables $(n=99)$

\begin{tabular}{|c|c|c|}
\hline Dependent variable & Description & Frequencies \\
\hline \multirow{5}{*}{ Perception of the EU requirements } & High risk & 7 \\
\hline & Risk & 16 \\
\hline & Unsure & 32 \\
\hline & Opportunity & 38 \\
\hline & High opportunity & 6 \\
\hline $\begin{array}{l}\text { Independent variables (economic } \\
\text { indicators) }\end{array}$ & Description & Frequencies \\
\hline \multirow[t]{3}{*}{ Legal form of ownership } & Joint stock & 41 \\
\hline & Limited & 46 \\
\hline & Other & 12 \\
\hline \multirow[t]{3}{*}{ Region } & Anatolia & 71 \\
\hline & Other & 18 \\
\hline & Multiregional & 10 \\
\hline \multirow[t]{2}{*}{ Family control } & No & 38 \\
\hline & Yes & 61 \\
\hline \multirow[t]{2}{*}{ Business abroad } & No & 27 \\
\hline & Yes & 72 \\
\hline \multirow{2}{*}{$\begin{array}{l}\text { Prevailing market served } \\
\text { (multidirectional) }\end{array}$} & No & 47 \\
\hline & Yes & 52 \\
\hline \multirow[t]{2}{*}{ Percent of products exported } & Less than $50 \%$ & 79 \\
\hline & More than $50 \%$ & 20 \\
\hline \multirow[t]{3}{*}{ Firm size } & Large: >100 employees & 30 \\
\hline & Medium: 51-100 employees & 23 \\
\hline & Small: 4-50 employees & 46 \\
\hline \multirow[t]{3}{*}{ Subsector } & Pastry & 44 \\
\hline & Other & 34 \\
\hline & Multi-production & 21 \\
\hline \multirow[t]{2}{*}{ Percent of products processed } & Less than $50 \%$ & 77 \\
\hline & More than $50 \%$ & 22 \\
\hline $\begin{array}{l}\text { Independent variables ( Knowledge } \\
\text { and personal indicators) }\end{array}$ & Description & Frequencies \\
\hline Age & Scale & 37.52 \\
\hline \multirow[t]{2}{*}{ Higher education } & No & 18 \\
\hline & Yes & 81 \\
\hline \multirow[t]{2}{*}{ Gender } & Female & 21 \\
\hline & Male & 78 \\
\hline \multirow[t]{6}{*}{ Department } & Director & 22 \\
\hline & Marketing & 23 \\
\hline & Quality management & 18 \\
\hline & Production & 14 \\
\hline & Other & 5 \\
\hline & Owner & 17 \\
\hline
\end{tabular}

Source: Survey data

Descriptive statistics for the objective data (independent variables) and the perception of EU requirements (dependent variable) are presented in Table 1. Obviously, the majority of processors interviewed perceive the EU regulation of their business as an opportunity. It is worth 
mentioning, however, that $32.3 \%$ were uncertain about the consequences of the EU requirements' regarding food quality and safety and $23.2 \%$ see risks or even high risks.

Applying exploratory factor analysis on the statements regarding perceptions of advantages, disadvantages, inciters, additional costs and competitive strategy yielded a variety of factors (see Appendix for a complete list). Three factors resulted from the statements regarding advantages: improved performance, competitive advantage, and work atmosphere. Factors related to the disadvantages were high requirements and insufficient consequences. Factors of internal and external inciters were determined by applying factor analysis on seven statements. Additional cost statements were summarized by two factors: establishment costs and supplementary costs. Regarding competitive strategy, hybrid and differentiation strategies were found to be the most important strategies perceived by the operators.

Ordinal regression analysis was carried out in order to explain perceptions of EU requirements based on the determinants derived from knowledge, personal and economic theories. The model presented in Table 2 is statistically highly significant (1\% level of significance). This indicates that the model improves our ability to predict the outcome, and the observed data are consistent with the fitted model. The pseudo- $R^{2}$ value represented by Nagelkerke's $R^{2}$ is recorded as 0.820. In fact, pseudo- $R^{2}$ statistics can be called "Multiple R-squared Analogs" (Cohen et al. 2003). In other words, it is an approximation telling us something similar to $R^{2}$ in an OLS (ordinary least-squares) regression. Higher values for Nagelkerke's $R^{2}(0.820)$ suggest that the model fits increasingly well. The model did not reveal multicollinearity problems (correlation ranging from 0.447 to 0.004 ). Indeed, the parallel lines assumption is satisfied because the null hypothesis, which states that the location parameters are same across response categories, was accepted. 
Table 2: Output of the estimated ordinal regression model

\begin{tabular}{|c|c|c|c|}
\hline Independent variables & & Base & Estimate \\
\hline - Legal form of ownership & $\begin{array}{l}\text { Limited } \\
\text { Other }\end{array}$ & Joint stock & $\begin{array}{l}8.37 * * * \\
5.18 * *\end{array}$ \\
\hline - Share of exported products & More than $50 \%$ & & $-5.94 * * *$ \\
\hline - Firm size & $\begin{array}{l}\text { Large: }>100 \text { employees } \\
\text { Medium: } 51-100 \text { employees }\end{array}$ & $\begin{array}{l}\text { Small: 4-50 em- } \\
\text { ployees }\end{array}$ & $\begin{array}{l}3.48 * * \\
5.24 * *\end{array}$ \\
\hline - Higher education & & & $4.39 * *$ \\
\hline - Gender & Male & & $4.98 * *$ \\
\hline - Department & $\begin{array}{l}\text { Director } \\
\text { Production }\end{array}$ & Owner & $\begin{array}{c}-3.859 * * \\
4.76 * *\end{array}$ \\
\hline $\begin{array}{l}\text { Advantages: } \\
\text { - Labor advantages }\end{array}$ & & & $-1.45^{* *}$ \\
\hline $\begin{array}{l}\text { Disadvantages: } \\
\text { - } \quad \text { High requirements }\end{array}$ & & & $-2.65 * * *$ \\
\hline $\begin{array}{l}\text { Additional costs: } \\
\text { - } \quad \text { Labor force costs }\end{array}$ & & & $2.04 * * *$ \\
\hline
\end{tabular}

Variables and models significant at $\mathrm{P}^{*} \leq 0.05, \mathrm{P}^{* *} \leq 0.01$ and $\mathrm{P}^{* * *} \leq 0.001$

Source: Survey data

Taking a closer look at the estimation results (Table 2), it seems that many indicators among the theoretical perspectives used in this study reveal an exploratory power to explain respondents' perceptions of EU requirements. More specifically, education level, as a knowledge indicator, has a considerable explanatory power in this field since it is positively related to the predicted variable at a $1 \%$ level of significance. Highly educated operators tend to exhibit more acceptance behavior toward EU rules in agribusiness. Producers with university degrees are considered more able to improve their knowledge and stay abreast of new applications, technologies, and regulations in their business environment. This parallels earlier findings, which show that learning orientation is an important driver of openness to innovation and new challenges (Hult et al. 2004).

In general, there is insufficient knowledge about food safety and quality requirements among Turkish producers compared to those in other developed countries. Koç et al. (2010) recognized that the information flow throughout the various food supply chains in Turkey is insufficient with regard to amount and clarity. Thus, there is a general lack of transparency (Deimel et al. 2008) and notable misunderstanding of food safety and food quality terms. A similar result 
was reported by Baş et al. (2006), who illustrated that directors and employees have insufficient knowledge regarding the basics of food hygiene. For instance, only eight of the 109 agri-food companies studied had implemented the HACCP concept. Earlier studies showed that reluctance to implement food quality and safety systems is often due to a lack of expected benefits (Heyder et al. 2011). Thus, producers' access to the rapid exchange of information in their businesses is deficient, and enterprises are weak in using extension, guidance, consulting and communication channels with government agencies, which could stress the high relevance of food safety and quality (Demirbas and Kargözlu 2008; Koç et al. 2011). Similarly, Koletzko (2008) revealed the importance of improved training, skills and motivation of operators and workers in order to enhance the implementation of effective food safety measures in food processing companies.

Education and knowledge may facilitate openness to new ideas and modern practices (Knight et al. 2003) and provide producers with a realistic image of the advantages of applying the EU regulations at firm level. Similarly, producers, who perceive "improvement of work atmosphere" as a major advantage of food safety and quality practices, view the implementation of the EU requirements in that area negatively. This suggests that operators need to know more about the benefits of improving food safety and quality systems in their businesses. Restrictive food safety standards can, for instance, facilitate trade and thus support profit maximization. Similarly, Çobanoğlu (2012) showed that, because of their strong belief that adoption of food safety standards could provide more gains than costs, managers of dried fig firms were more willing to cope with EU regulations imposing strict aflatoxin limits.

Significant interactions have been observed for gender and department occupation. Male operators and those who work in a production department are more likely to perceive adoption of the EU requirements in their firms as an opportunity for advancement. Conversely, firm directors often consider coping with the EU obligations a threat to success. These observed variances can be attributed to the disparate awareness of what EU requirements actually mean for agribusiness companies, different expectations concerning financial burdens and unclear decision-making responsibilities within the firm. Firm directors were assumed to accept the costs and other challenges that might accompany compliance with EU regulations and harmonization within the food industry.

The empirical results indicate that firm size is positively and significantly associated with managers' perceptions of EU regulations. Large-scale food processors exhibit notable attempts to harmonize with EU food regulations. This finding is in accordance with the fact that large 
agri-food firms have greater opportunities to export to EU markets, so they easily fulfil the required safety and quality requirements. In general, several papers have emphasized that larger firms have a greater capacity—particularly a greater financial capacity — to implement food safety and quality controls (Ollinger et al. 2004; Jayasinghe-Mudalige and Henson 2007; Handschuch et al. 2013). In Turkey, however, there are a large number of small-scale manufacturers with a limited capacity to obtain quality certificates and thus to receive the potential benefits of doing so. Moreover, coordination and collaboration among small enterprises in the food chain are too weak to develop/ensure food safety and quality assurance scheme (Koç et al. 2010). Similar profiles were outlined by Kumar et al. (2011), who confirmed that cooperation along the modern milk supply chain in India enforced the prospects of higher compliance with food safety measures by the transfer of innovative knowledge and skills and reduced transaction costs. Small producers and enterprises are not financially supported in improving quality assurance, and it is hard for them to accumulate the capital needed to use advanced marketing strategies. This situation leads to their exclusion from dynamic food markets (Koç et al. 2011).

The results in Table 2 reveal that perceptions of disadvantages and additional costs influence the perceptions of EU food safety and quality requirements. Operators' perceptions of implementation of food safety and quality assurance schemes as a high requirement reduce their acceptance of the EU regulations. This is in line with the Technology Acceptance Model, which proposes that higher perceived costs reduce willingness to implement such technologies as advanced tracking and tracing systems (Heyder et al. 2011). This suggests that the establishment costs and awareness of high requirements could limit acceptance of the EU regulations. With accession to EU markets, severe food safety and quality standards must be complied with in the long run, leading to higher production costs. This parallels the findings of Kumar et al. (2011), who concluded that, to achieve the desired level of compliance with food safety measures in the dairy industry, the cost of milk production in India would increase by 0.50 Indian rupees per liter.

Regarding share of products exported, firms with lower export orientations tend to perceive compliance with EU requirements as an opportunity. High-export enterprises are commanded to meet various legal requirements and customer demands requested by importing countries and/or multinational food retail chains, which may not necessarily include the EU. Hence, they may have no capacity to cope with more requirements, such as the rigorous regulations relevant on the EU market. 
Surprisingly, legal form of ownership exhibits an unexpected relation with perceptions of EU requirements. Joint stock companies are less likely to accept such requirements compared to limited companies. In fact, the greater financial capacity in joint stock firms and their option of going public by issuing bonds are thought to intensify the capability of these firms to fulfil the EU requirements. Against this background, other unobserved variables could influence our result.

\section{Conclusions, implications and future research}

Since food producers in Turkey cannot produce at the same quality level as their competitors in EU countries, empirical analysis that identifies the perceptions of EU food regulation among Turkish producers is needed. This study revealed that perception of the EU requirements is very closely linked to the knowledge and the personal and economic characteristics of Turkish food processors. More precisely, improving knowledge about food safety and quality perceptions decisively increases firms' ability to cope with the EU instructions. In Turkey the means available for training, communication and general information seem less than satisfactory and must be enhanced. For this purpose, campaigns should be organized among responsible institutions and the media about food safety and quality in the agri-food sector. Furthermore, public subsidies may be needed to support training activities.

Perception of food safety and quality as high requirement issues negatively affects the EU harmonization in Turkish agribusinesses, particularly in small-scale enterprises. Therefore, increased EU food quality and safety requirements require catalyst effects at the national level. This can be done through new investment, research expenditure, consolidation and increased vertical coordination at various levels of the supply chain (Jaffee and Henson 2004; Anders and Caswell 2009).

Addressing operators' acceptance of food safety laws required by the EU is challenging. This study mainly investigated predictors related to the business environment. Environmental factors, however, may also contribute. Moreover, since the perception and impact of EU regulations may vary, depending on the characteristics of the agri-food subsector under analysis, comprehensive studies should take these determinants into account. In Turkey, the number of academic studies and research projects conducted on this topic is still limited. All in all, such efforts need to be extended and the alignment of Turkish legislation with EU legislation completed accordingly. 


\section{Bibliography}

Akşit, S. and Üstün, Ç. (2009). Introduction: In search of an EU-wide debate on Turkey. In: Akşit, S., Şenyuva, Ö. and Üstün, Ç. (Eds.). Turkey watch: EU member states' perception on Turkey's accession to the EU. Center for European Studies, Middle East Technical University, Ankara.

Alpay, S., Dabour, N.M., Aydin, A.S., Tintin, C., Ünal, U., Bağci, K., Korbayram, A. and Hussain, M. (2013). State of agriculture and food security in OIC member countries: Opportunities for cooperation. SESRIC. Statistical, Economic and social Research and Rraining Center for Islamic Countries. Oran, Ankara.

Ananth, C. V. and Kleinbaum, D. G. (1997). Regression models for ordinal responses: A review of methods and applications. International Journal of Epidemiology, 26 (6), 1323-1333.

Anders, S.M. and Caswell, J.A. (2009). Standards as barriers versus standards as catalysts: Assessing the impact of HACCP implementation on US seafood imports. American Journal of Agricultural Economics, 91, 310-321.

Antonucci, D. and Manzocchi, S. (2006). Does Turkey have a special trade relation with the EU? A gravity model approach. Economic Systems, 30 (2), 157-169.

Atici, C. (2013). Food safety regulations and export responses of developing countries: The case of Turkey's fig and hazelnut exports. FAO. Food and Agriculture Organization of the United Nations, Commodity and Trade Policy Research, working paper No. 39.

Baş, M., Ersun, A.Ş. and Kıvanç, G. (2006). Implementation of HACCP and prerequisite programs in food businesses in Turkey. Food Control, 17 (2), 118-126.

Baş, M., Yüksel, M. and Çavuşoğlu, T. (2007). Difficulties and barriers for the implementing of HACCP and food safety systems in food businesses in Turkey. Food Control, 18 (2), 124-130.

Bidault, H. (2012). Turkey-EU accession negotiations opening of new chapters and their implications. ADMD Law Office, Istanbul. URL: http://www.admdlaw.com/turkey-eu-accessionnegotiations-opening-of-new-chapters-and-their-implications/\#.VD6TTld52hZ.

Accessed: 11.10.2014. 
Burrell, A. (2008). EU enlargement to Turkey? The challenges ahead for agriculture and rural areas: EU erweiterung um die Türkei? herausforderungen füer die landwirtschaft und ländliche Räume: Elargir I'UE à la Turquie? Les défis en perspective pour I'agriculture et les zones rurales. EuroChoices, 4 (1), 12-17.

Cakmak, E.H. and Dudu, H. (2013). Economic growth in the Euro-Med Area through trade integration: Focus on agriculture and food, the case study of Turkey. European Commission, Joint Research Centre, Institute for Prospective Technological Studies, JRC Scientific and Technical Reports, Seville, Report EUR 26532 EN, Spain.

Cobanoglu, F. (2012). Is export orientation a major motivator for the adoption of food safety systems in the Turkish dried fig firms? Journal of Agriculture and Rural Development in the Tropics and Subtropics, 113 (1), 31-42.

Çobanoğlu, F., Karaman, A.D. and Tunalioglu, R. (2013). Critical evaluation for adoption of food safety systems in the Turkish dairy and meat processing businesses. Journal of Agricultural Science and Technology, 15 (1), 101-114.

Cohen, J., Cohen, P., West, S. G. and Aiken, L. S. (2003). Applied multiple regression/correlation analysis for the behavioral sciences. Lawrence Erlbaum Associates, New Jersey.

Deimel, M., Frentrup, M. and Theuvsen, L. (2008). Transparency in food supply chains: Empirical results from German pork and dairy production. Journal on Chain and Network Science 8 (1), 21-32.

Demirbas, N. and Karagözlu, C. (2008). Constraints in meeting food safety and quality requirements in the Turkish dairy industry: A case study of Izmir province. Journal of Food Protection, $71(2), 440-444$.

Demirbas, N., Gölge, E., Tosun, D. and Cukur, F. (2008). Food safety practices in milk collection centers in Turkey: A case study. British Food Journal, 110 (8), 781-789.

European Commission. (2007). Screening report: Turkey. Chapter 12: Food safety, veterinary and phytosanitary policy. Screening meetings, March and April 2006, Brussels. URL: http://ec.europa.eu/enlargement/pdf/turkey/screening_reports/screening_report_12_tr_internet_e n.pdf. Accessed: 11.10.2014. 
European Commission. (2014). Turkey: 2014 progress report. Commission staff working document, Brussels, 08.10.2014, SWD(2014) 307 final. URL: http://ec.europa.eu/enlargement/pdf/ key_documents/2014/20141008-turkey-progress-report_en.pdf. Accessed: 12.10.2014.

Fellmann, T., van Leeuwen, M. and Salamon, P. (2011). EU enlargement to Turkey: Potential Iimpacts on agricultural markets and how they are shaped by changes in macroeconomic conditions. German Association of Agricultural Economists (GEWISOLA), 51st Annual Conference, Halle, Germany, September 28-30, 2011 (No. 114507).

Garcia, M., Poole, N., Briz, J., de Felipe, I., Yalcin, I., Koc, A., and Messaho, D. (2004). Benchmarking international food safety performance in the fresh produce sector. EAAE 84th Seminar on Food Safety in a Dynamic World, February 8-11, 2004, Zeist, The Netherlands.

Greenland, S. (1985). An application of logistic models to the analysis of ordinal responses. Biometrical Journal, 27 (2),189-197.

Guittard, C. (2006). Food safety situation in Turkey. DG Internal Polices of the Union, Policy Department Economic and Scientific Policy, (IP/A/ENVI/OF/2006-104), PE 375.850. European parliament URL: http://www.europarl.europa.eu/RegData/etudes/note/join/2006/375850/IPOLENVI_NT\%282006\%29375850_EN.pdf. Accessed: 06.09.2014.

Hair, F., Jr., Black, W. C., Babin, B. J. and Anderson, R. E. (2010). Multivariate data analysis. 7th Edition. Pearson Prentice Hall.

Handschuch, C., Wollni, M. and Villalobos, P. (2013). Adoption of food safety and quality standards among Chilean raspberry producers: Do smallholders benefit? Food Policy, 40 (1), 6473.

Heyder, M., Hollmann-Hespos, T. and Theuvsen, L. (2011). Investments in tracking and tracing systems in the food industry: A PLS analysis. Food Policy, 37 (1), 102-113.

Hillson, D. and Murray-Webster, R. (2004). Understanding and managing risk attitude. In Proceedings of 7 th Annual Risk Conference, London. URL: http://www.riskattitude.com/riskattitude_paper.pdf. Accessed: 26.04.2013. 
Hult, G.T.M., Hurley, R.F. and Knight, G.A. (2004). Innovativeness: Its antecedents and impact on business performance. Industrial Marketing Management, 33 (5), 429-438.

IPA II. Instrument for Per-Accession Assistance. (2014). Indicative strategy paper for Turkey (2014-2020). European Commission. URL: http://ec.europa.eu/enlargement/pdf/key_documents/ 2014/20140919-csp-turkey.pdf. Accessed: 01.10.2014.

Jaffee, S. and Henson, S. (2004). Standards and agro-food exports from developing countries: Rebalancing the debate. World Bank Policy Research Working Paper 3348. URL: http://elibrary.worldbank.org/doi/pdf/10.1596/1813-9450-3348. Accessed: 11.10.2014.

Jayasinghe-Mudalige, U. and Henson, S. (2007). Identifying economic incentives for Canadian red meat and poultry processing enterprises to adopt enhanced food safety controls. Food Control, $18(11), 1363-1371$.

Keenan, S., Hammond, J., Leeks, D. and Misiova, I. (2011). Food safety and public health situation in Turkey. ENVI delegation to Turkey (2-4 November 2011), Director General for Internal Policies, Director A: Economic and Scientific Policy. European Parliament. URL: http://www.europarl.europa.eu/document/activities/cont/201111/20111111ATT31265/20111111 ATT31265EN.pdf. Accessed: 06.02.2013.

Knight, J., Weir, S. and Woldehanna, T. (2003). The role of education in facilitating risk-taking and innovation in agriculture. The Journal of Development Studies, 39 (6), 1-22.

Koç, A. A., Asci, S., Alpas, H., Giray, F. H. and Gay, S. H. (2010). Food quality and safety situation in Turkey: Governance and barriers to success. Food Economics-Acta Agricult Scand C, 7 (2-4), 245-259.

Koç, A. A., Asci, S., Alpas, H., Giray, F.H. and Gay, S.H. (2011). Food Quality Assurance Schemes in Turkey. European Commission, Joint Research Centre, Institute for Prospective Technological Studies, JRC Scientific and Technical Reports, Report EUR 24672 EN - 2011.

Kök, M. S. (2009). Application of food safety management systems (ISO 22000/HACCP) in the Turkish poultry industry: A comparison based on enterprise size. Journal of Food Protection, $72(10), 2221-2225$. 
Koletzko, B. (2008). Food safety situation in Turkey: Note. DG Internal Polices of the Union, Policy Department Economic and Scientific Policy (IP/A/ENVI/NT/2008-20, PE 408.568). European Parliament. URL: http://www.europarl.europa.eu/RegData/etudes/note/join/2008/ 408568/IPOL-ENVI_NT\%282008\%29408568_EN.pdf. Accessed: 06.09.2014.

Kumar, A., Wright, I. A. and Singh, D. K. (2011). Adoption of food safety practices in milk production: Implications for dairy farmers in India. Journal of International Food and Agribusiness Marketing, 23 (4), 330-344.

Lee, J. (1992). Cumulative logit modelling for ordinal response variables: Applications to biomedical research. Computer applications in the biosciences: CABIOS, 8 (6), 555-562.

Mutlu, S., Bal, T., Say, D. and Emeksiz, F. (2003). The adoption and implementation of the food quality system (HACCP) in Mediterranean Region of Turkey. In: Nikolaidis, A., Baourakis, G., Isikli, E. and Yercan, M. (Eds.). The market for organic products in the Mediterranean region. CIHEAM, Cahiers Options Méditerranéennes, Chania, 61, 201-217.

Official Gazette. (2010). TÜRK TİCARET KANUNU No. 27610, 13.06.2010. URL: http://www.resmigazete.gov.tr/eskiler/2010/06/20100613-12.htm. Accessed: 12.10.2014.

Ollinger, M.E., Moore, D. and Chandran, R. (2004). Meat and poultry plant's food safety investments: Survey findings. Technical Bulletin No. 1911, United States Department of Agriculture, Economics Research Service. Washington, DC.

Scott, S. C., Goldberg, M. S., \& Mayo, N. E. (1997). Statistical assessment of ordinal outcomes in comparative studies. Journal of Clinical Epidemiology, 50 (1), 45-55.

Sözen, B.U. and Hecer, C. (2013). Is HACCP a difficult food safety system to implement? Journal of Biological and Environmental Sciences, 7 (19), 33-38.

van Berkum, S. (2005). Is the Turkish agri-food sector ready for EU entry? The future of rural Europe in the global agri-food system, EAAE XIth Conference, August 24-27, 2005, Copenhagen.

Van Raaij, W. F. (1981). Economic psychology. Journal of Economic Psychology, 1 (1), 1-24. 
Wildavsky, A. and Dake, K. (1990). Theories of risk perception: Who fears what and why? Daedalus, 119 (4), 41-60.

Wilson, P. N., Dahlgran, R. D., Conklin, N. C., Armstrong, D., and Luginsland, T. (1993). Perceptions as reality on large-scale dairy farms. Review of Agricultural Economics, 15 (1), 89-101. 


\section{Appendix}

1. Varimax rotated factor loadings of advantages statements

\begin{tabular}{|c|c|c|c|}
\hline \multirow[b]{2}{*}{ Advantages } & \multicolumn{2}{|c|}{ Factors } & \multirow[b]{2}{*}{$\begin{array}{c}\text { Work atmos- } \\
\text { phere }\end{array}$} \\
\hline & $\begin{array}{l}\text { Improved perfor- } \\
\text { mance }\end{array}$ & $\begin{array}{l}\text { Competitive } \\
\text { advantages }\end{array}$ & \\
\hline Well-structured description of requirements & 0.596 & 0.256 & 0.283 \\
\hline Improved customer satisfaction & 0.702 & 0.397 & 0.269 \\
\hline Improved product quality & 0.799 & 0.087 & 0.255 \\
\hline Increase in corporate profits & 0.694 & 0.353 & 0.054 \\
\hline Positive impact on business processes & 0.803 & 0.189 & 0.276 \\
\hline Fewer accidents at work & 0.165 & 0.111 & 0.768 \\
\hline $\begin{array}{l}\text { Better communication between employer and } \\
\text { employees }\end{array}$ & 0.388 & 0.170 & 0.822 \\
\hline Higher employee motivation & 0.180 & 0.167 & 0.839 \\
\hline Enhanced confidence within the company & 0.242 & 0.369 & 0.479 \\
\hline Improved export opportunities & 0.219 & 0.814 & 0.153 \\
\hline $\begin{array}{l}\text { Increase market share / better market opportuni- } \\
\text { ties }\end{array}$ & 0.237 & 0.880 & 0.197 \\
\hline Efficiency increase & 0.313 & 0.846 & 0.203 \\
\hline Eigenvalues & 5.95 & 1.39 & 1.06 \\
\hline Per cent of total variance explained & 25.39 & 22.93 & 21.72 \\
\hline Cumulative per cent of the variance explained & 25.39 & 48.33 & 70.04 \\
\hline Cronbach's alpha & 0.84 & 0.89 & 0.82 \\
\hline
\end{tabular}

\section{Varimax rotated factor loadings of disadvantages statements}

\begin{tabular}{lcc}
\hline \multirow{2}{*}{ Disadvantages } & \multicolumn{2}{c}{ Factors } \\
\cline { 2 - 3 } Time consuming and expensive preparation of & High requirements & Insufficient consequences \\
documents & $\mathbf{0 . 7 5 9}$ & 0.223 \\
Difficult-to-understand requirements & $\mathbf{0 . 6 6 4}$ & 0,526 \\
High costs & $\mathbf{0 . 8 0 1}$ & 0.138 \\
Reactance towards innovations in the company & $\mathbf{0 . 5 5 3}$ & 0.090 \\
New employees had to be hired & $\mathbf{0 . 7 8 4}$ & 0.023 \\
Too high costs & $\mathbf{0 . 7 0 1}$ & 0.161 \\
Auditors cannot decide independently & 0.337 & $\mathbf{0 . 7 5 9}$ \\
The audit quality was too poor & 0.084 & $\mathbf{0 . 9 3 2}$ \\
The audit results were too bad & 0.062 & $\mathbf{0 . 9 2 1}$ \\
Insufficient communication by standard setter & 0.202 & $\mathbf{0 . 6 6 6}$ \\
\hline Eigenvalues & 4.24 & 1.90 \\
Percent of total variance explained & 32.36 & 29.05 \\
Cumulative percent of the variance explained & 32.39 & 61.41 \\
Cronbach's alpha & 0.83 & 0.86 \\
\hline
\end{tabular}




\section{Varimax rotated factor loadings of inciters' statements}

\begin{tabular}{lcc}
\hline \multirow{2}{*}{ Inciters } & \multicolumn{2}{c}{ Factors } \\
\cline { 2 - 3 } Local proximity to the auditor & External & Internal \\
\hline Pressure from importing countries & $\mathbf{0 . 7 6 6}$ & 0.259 \\
Pressure from customers & $\mathbf{0 . 7 4 9}$ & 0.095 \\
Less bureaucratic than other systems & $\mathbf{0 . 7 8 1}$ & -0.149 \\
Well-known certification body & $\mathbf{0 . 6 6 9}$ & 0.297 \\
Cost-benefit ratio & $\mathbf{0 . 5 9 3}$ & 0.399 \\
More effective than other systems & 0.245 & $\mathbf{0 . 8 4 9}$ \\
Eigenvalues & 0.018 & $\mathbf{0 . 8 9 5}$ \\
Percent of total variance explained & 3.14 & 1.35 \\
Cumulative percent of the variance explained & 37.83 & 26.68 \\
Cronbach's alpha & 37.83 & 64.06 \\
\hline
\end{tabular}

\section{Varimax rotated factor loadings of additional cost statements}

\begin{tabular}{lcc}
\hline \multirow{2}{*}{ Additional cost } & \multicolumn{2}{c}{ Factors } \\
\cline { 2 - 3 } & Establishment costs & Supplementary costs \\
\hline Calibration costs & $\mathbf{0 . 8 8 9}$ & 0.147 \\
Maintenance costs & $\mathbf{0 . 8 4 2}$ & 0.304 \\
Laboratory and analysis costs & $\mathbf{0 . 8 0 6}$ & 0.200 \\
Infrastructure and building renovation & $\mathbf{0 . 7 7 8}$ & 0.280 \\
Cleaning workers & $\mathbf{0 . 6 3 8}$ & 0.374 \\
\hline Documentation requirements & 0.118 & $\mathbf{0 . 9 1 4}$ \\
Employee training & 0.273 & $\mathbf{0 . 7 5 4}$ \\
Changes in management & 0.377 & $\mathbf{0 . 6 2 0}$ \\
Eigenvalues & 4.45 & 1.11 \\
Percent of total variance explained & 42.40 & 27.10 \\
Cumulative percent of the variance explained & 42.40 & 69.41 \\
Cronbach's alpha & 0.90 & 0.73 \\
\hline
\end{tabular}

\section{Varimax rotated factor loadings of competitive strategy statements}

\begin{tabular}{lcc}
\hline \multirow{2}{*}{ Competitive strategy } & \multicolumn{2}{c}{ Factors } \\
\cline { 2 - 3 } & Hybrid & Differentiation \\
\hline Ensure efficiency of business processes & $\mathbf{0 . 7 1 0}$ & 0.141 \\
Low procurement costs & $\mathbf{0 . 7 7 7}$ & 0.229 \\
Innovative marketing & $\mathbf{0 . 7 8 8}$ & 0.171 \\
Offer low prices & $\mathbf{0 . 5 5 4}$ & -0.290 \\
Communicate brand and company reputation & $\mathbf{0 . 7 0 0}$ & 0.334 \\
\hline On international markets, we compete on quality and innovation leadership. & 0.054 & $\mathbf{0 . 8 5 8}$ \\
On international markets, we serve niche markets. & 0.101 & $\mathbf{0 . 9 3 0}$ \\
We are usually ahead of our competitors with new products on the market. & 0.313 & $\mathbf{0 . 6 5 4}$ \\
Eigenvalues & 3.33 & 1.64 \\
Percent of total variance explained & 32.96 & 29.08 \\
Cumulative percent of the variance explained & 32.96 & 62.03 \\
Cronbach's alpha & 0.74 & 0.78 \\
\hline
\end{tabular}


Teil IV: Muslimische Konsumenten in Deutschland: Kenntnis und Bedeutung der Halal-Kennzeichnung

Ahmet Sahin, Tuba Pekkirbizli, Maike Kayser, Ludwig Theuvsen

Erschienen in:

Berichte über Landwirtschaft, Band 92 (2), August 2014 


\title{
Muslimische Konsumenten in Deutschland: Kenntnis und Bedeutung der Halal-Kennzeichnung
}

\author{
Muslim consumers in Germany: Knowledge and significance \\ of the halal labeling
}

\section{Consommateurs musulmans en Allemagne: La connaissance et l'importance d'un label «Halal»}

Ahmet Sahin, Tuba Pekkirbizli, Maike Kayser, Ludwig Theuvsen, Göttingen

\section{Muslime als Zielgruppe im deutschen Lebensmittelmarkt}

Folgt man den Angaben des Statistischen Bundesamtes, dann umfasste die Bevölkerung der Bundesrepublik Deutschland Ende 2012 rund 80,5 Mio. Menschen. Immerhin 19,5 \% der in Deutschland lebenden Menschen - in absoluten Zahlen sind dies knapp 16 Mio. Einwohner wird vom Statistischen Bundesamt ein sog. Migrationshintergrund attestiert (29). „Zur Bevölkerung mit Migrationshintergrund zählen alle, die nach 1949 auf das heutige Gebiet der Bundesrepublik Deutschland zugezogen sind, alle in Deutschland geborenen Ausländer/-innen und alle in Deutschland mit deutscher Staatsangehörigkeit Geborenen mit zumindest einem zugezogenen oder als Ausländer in Deutschland geborenen Elternteil.“(28). Als wichtigste Herkunftsländer für Menschen mit Migrationshintergrund in Deutschland nennt das Statistische Bundesamt für das Jahr 2011 die Türkei (rund 3,0 Mio.), Polen (1,5 Mio.), die Russische Föderation (1,2 Mio.), Kasachstan (0,9 Mio.) und Italien (0,8 Mio.) (28). 1,9\% der Befragten oder mehr als 1,5 Mio. Menschen haben sich in dem vom Statistischen Bundesamt durchgeführten Mikrozensus zum Islam bekannt. Allerdings geht das Statistische Bundesamt davon aus, dass von dieser Bevölkerungsgruppe besonders viele Befragte von ihrem Recht Gebrauch gemacht haben, auf die Beantwortung der Frage zur Religionszugehörigkeit zu verzichten (4).

Für die Vermarktung von Lebensmitteln hat die zunehmende Heterogenität der Bevölkerung Deutschlands weitreichende Konsequenzen, da der Lebensmittelkonsum in starkem Maße kulturell geprägt ist $(3 ; 12)$. Modelle zur Erklärung des menschlichen Einkaufs- oder Ernährungsverhaltens berücksichtigen dementsprechend in aller Regel immer auch eine (sozio-)kulturelle Dimension, die die durch soziale Lernprozesse erworbenen und als selbstverständlich erachteten 
Werte und Normen (22), die die Einstellungen von Individuen zum Kauf und Konsum bestimmter Lebensmittel determinieren, berücksichtigt (2). Ein Beispiel ist das neobehavioristische Stimulus-Organismus-Response-(SOR)-Modell, in dem die Kultur als Einflussfaktor auf die z.B. durch Marketing-Stimuli (etwa den Preis) ausgelösten aktivierenden und kognitiven Prozesse im Organismus verstanden wird (16). Empirische Untersuchungen zeigen zudem, dass Einwanderer ihre kulturell bedingten Verhaltensmuster auch in der neuen Umgebung beibehalten - mit entsprechenden Auswirkungen auf ihr Einkaufsverhalten (7).

Eine besondere Relevanz für die Agrar- und Ernährungswirtschaft erlangen soziokulturelle Determinanten des Ernährungsverhaltens, wenn sie mit Lebensmitteltabus, etwa dem Verzicht auf den Konsum bestimmter Produkte tierischen Ursprungs, oder besonderen Anforderungen an die Verarbeitung und Zubereitung von Lebensmitteln bzw. Speisen einhergehen. Derartige soziokulturell vermittelte Regeln spiegeln sich dann unmittelbar im Einkaufsverhalten und den Verzehrsgewohnheiten der Verbraucher wider.

Auch wenn die amtliche Statistik weiterhin keine genauen Zahlen bereitzustellen in der Lage ist, so ist doch davon auszugehen, dass größere Teile der in Deutschland lebenden Menschen mit Migrationshintergrund Muslime sind. So werden durch das Statistische Bundesamt (28) allein rund 3 Mio. Menschen mit Migrationshintergrund dem Herkunftsland ,Türkei` zugerechnet. $85 \%$ der Menschen türkischer Herkunft geben in Befragungen an, Muslime zu sein. Entsprechend wird die Zahl der in Deutschland lebenden Muslime auf etwa 3,8 bis 4,3 Mio. geschätzt und damit deutlich höher als in den offiziellen Verlautbarungen des Statistischen Bundesamtes angegeben (19). Größere Teile der Muslime in Deutschland richten ihr Leben vollständig oder überwiegend nach dem Islam aus; bei den Menschen mit türkischen Wurzeln sind dies nach früheren Untersuchungen $43 \%$ (1).

Für Muslime gelten eine Reihe von Speisevorschriften, die unter anderem den Konsum von Lebensmitteln tierischen Ursprungs betreffen. So sagt Sure 5, Vers 4: „Verboten ist euch das von selbst Verendete sowie Blut und Schweinefleisch und das, worüber ein anderer Name angerufen ward als Allahs; das Erdrosselte; das zu Tode Geschlagene; das zu Tode Gestürzte oder Gestoßene und das, was reißende Tiere angefressen haben, ..., was auf einem Altar (als Götzenopfer) geschlachtet worden ist ...“ (Koranübersetzung, 18. Auflage, München 2003, zitiert nach Aygün (1, S. 70). Menschen, die ihre Leben ganz oder teilweise nach dem Islam ausrichten, ist die Befolgung der Ge- und Verbote im Bereich des Lebensmittelkonsums wichtig. Der ethnische bzw. hybride ethnische Einzelhandel, der ausschließlich oder ergänzend Sortimente führt, die auf- 
grund von Rezepturen, Verpackungsbeschriftung, Markennamen o.ä. als typisch für die ursprünglichen Herkunftsländer der in Deutschland lebenden Muslime, etwa die Türkei, empfunden werden, kommt diesem Bedürfnis entgegen, indem er Lebensmittel anbietet, die als „helal“ (türkisch) oder „halal“ (arabisch) gekennzeichnet sind (1). Halal ist alles, was nicht haram ist, also gegen ein absolutes Verbot Gottes verstößt und seine Bestrafung im Jenseits nach sich ziehen würde (26). Die Kennzeichnung als halal signalisiert Muslimen, dass sie die entsprechenden Produkte unbesorgt kaufen können, da bei ihrer Herstellung die islamischen Vorschriften eingehalten wurden (1).

Vor dem beschriebenen Hintergrund ist es das Ziel des vorliegenden Beitrags, auf der Grundlage einer empirischen Untersuchung erste Einblicke in den Stellenwert einer Kennzeichnung von Lebensmitteln als helal bzw. halal für Muslime zu erhalten und daraus Schlussfolgerungen für die Vermarktung von Lebensmitteln in Deutschland abzuleiten. Zu diesem Zweck werden im Folgenden zunächst der Begriff halal und die Halal-Zertifizierung (Kapitel 2) sowie die Untersuchungsmethode und die Stichprobe näher beschrieben (Kapitel 3). Anschließend werden die Ergebnisse der empirischen Untersuchung vorgestellt (Kapitel 4). Einige Schlussfolgerungen beschließen den Beitrag (Kapitel 5).

\section{Halal-Lebensmittel und-Zertifizierung}

Wie im Eingangskapitel bereits erwähnt, gelten für Muslime Regeln und Vorschriften für den Konsum von Lebensmitteln. Auf diesen Komplex soll im Folgenden detaillierter eingegangen werden. Nach den Regeln des Korans und den Worten Mohammeds sollen grundsätzlich gesundheitlich unbedenkliche Lebensmittel verzehrt werden. Neben der Einteilung in „halal“ (erlaubt) und „haram“ (verboten, unrein) kategorisiert der Islam noch Lebensmittel als „makruh“ (verpönt, unerwünscht), die im Grenzbereich zwischen erlaubten und nicht erlaubten Lebensmitteln stehen, aber deren Verzehr für Muslime meist als haram gilt. Überdies sei noch angemerkt, dass die Halal-Grundsätze des Islams sich nicht nur auf den Verzehr, sondern auf den gesamten Prozess der Erzeugung, Düngung, Fütterung, Aufzucht und Schlachtung („Schächtung“) der Produkte beziehen (21).

Im Zuge der Globalisierung und der auch in den Ländern des Islams einhergehenden Industrialisierung der Agrar- und Ernährungswirtschaft haben sich in den vergangenen zwei Jahrzehnten verschiedene Standards und Zertifizierungen für Halal-Lebensmittel etabliert, um sowohl dem muslimischen Verbraucher als auch den Importländern hinsichtlich der Einhaltung verschiedener 
Bestimmungen, in der Bundesrepublik Deutschland z.B. in Bezug auf den Tierschutz, Sicherheit zu gewährleisten.

Aufgrund der verschiedenen Ausprägungen des Islams (Schiiten, Sunniten, Ibadi, Zahiriya), die jeweils unterschiedliche Prinzipien und Lehrmeinungen betreffend ihrer religiösen Praxis verfolgen, entstanden parallel mehrere Systeme, so z.B. JAKIM Malaysia, LP-POM MUI Indonesia, Halal-Control (EU) - Halal-Zertifizierung (31).

Jedes Land hat seine eigene Zertifizierungsstelle und seine individuellen Praxisanwendungen in Bezug auf Futtermittel, Schlachtmethoden, Verpackung, Lagerung, Logistik usw. Verschiedene Halal-Behörden folgen unterschiedlichen islamischen Vorschriften, besonders in Bezug auf Gelatine, einige Lebensmittelzusätze, die Schlachtmethode und die Betäubung der Tiere. Diese unterschiedlichen Systematiken können in Einzelfällen Irritationen zur Folge haben. Einerseits wissen die Hersteller nicht, welche Behörde zu konsultieren ist, andererseits ist es für die muslimischen Verbraucher schwierig, Vertrauen, Sicherheit und Orientierung bei ihrem Einkauf zu gewinnen (13).

Das Standards and Metrology Institute for Islamic Countries (SMIIC) beabsichtigt, die existierenden Normen zu harmonisieren, die technischen Handelshemmnisse zu beseitigen und die Handelsbeziehungen zwischen den Mitgliedstaaten der Organization of Islamic Cooperation (OIC) weiter zu entwickeln. Die Arbeit des SMIIC zielt darauf ab, die Messtechnik, die Labortests sowie die Standardisierungsaktivitäten und Akkreditierungstätigkeiten zu vereinheitlichen, ferner ein nachhaltiges Wirtschaftswachstum zu unterstützen sowie Weiterbildung und technische Hilfe zu fördern (10).

Die OIC erarbeitete in Zusammenarbeit mit dem SMIIC drei Richtlinien für Zertifizierungssysteme, die von 39 der gegenwärtig 57 Mitgliedstaaten der OIC zum 17. Mai 2011 in Kraft gesetzt wurden:

- $\quad$ OIC/SMIIC 1: 2011, General Guidelines on Halal Food

- $\quad$ OIC/SMIIC 2: 2011, Guidelines for Bodies Providing Halal Certification

- OIC/SMIIC 3: 2011, Guidelines for the Halal Accreditation Body Accrediting Halal.

Die folgenden Dokumente sind für die Anfrage der Halal-Zertifizierung erforderlich:

- CODEX STAN 1, Allgemeiner Kodex für die Kennzeichnung von verpackten Lebensmitteln,

- CAC/RCP 1, Empfohlener internationaler Verfahrenskodex - Allgemeine Grundsätze der Lebensmittelhygiene, 
- CAC/RCP 58, Kodex der Hygienepraxis für Fleisch,

- ISO 22000, Managementsysteme für die Lebensmittelsicherheit - Anforderungen an Organisationen in der Lebensmittelkette

- $\quad$ ISO 22005, Rückverfolgbarkeit in der Futter-und Lebensmittelkette (27).

Die folgenden Produkte und Dienstleistungen werden durch die Zertifizierung abgedeckt: Fleisch und Fleischerzeugnisse, Milch und Milchprodukte, Ei und Eiprodukte, Getreide und Getreideerzeugnisse, pflanzliche und tierische Öle und Fette, Obst und Gemüse und ihre Produkte, Zucker und Süßwaren, Getränke (Softdrinks), Honig und seine Nebenprodukte, Nahrungsergänzungsmittel, gentechnisch veränderte Lebensmittel, Lebensmittel-Zusatzstoffe, Enzyme, Mikroorganismen, Verpackungsmaterialien, Food-Service und Räumlichkeiten, Fisch und Fischprodukte, Wasser, Sonstiges (17).

Die folgenden Tiere werden als Halal-Tiere beschrieben:

- Domestizierte Tiere wie Rinder, Büffel, Schafe, Ziegen Kamele, Hühner, Gänse, Enten und Puten.

- Nicht-räuberische wilde Tiere wie Hirsche, Antilopen, Gämsen, Wildrinder.

- Nicht-räuberische Vögel wie Tauben, Wachteln, Spatzen, Stare und Strauße.

- $\quad$ Alle Arten von Fischen mit Schuppen, Garnelen, Fischeier einschließlich ihrer Produkte und alle anderen Wassertiere sowie deren Nebenprodukte (5).

Als haram (nicht halal) gelten dagegen:

- $\quad$ Schweine, Hunde Esel und Maultiere.

- $\quad$ Tiere mit langen, spitzen Zähne oder Stoßzähnen, um Beute zu töten oder sich zu verteidigen, wie Bären, Elefanten, Affen, Wölfe, Löwen, Tiger, Panther, Hauskatzen, Schakale, Füchse, Eichhörnchen, Marder, Wiesel und Maulwürfe, Krokodile und Alligatoren usw.

- $\quad$ Raubvögel mit scharfen Krallen wie Habichte, Falken, Adler, Geier, Raben, Krähen, Milane, Eulen.

- Schädlinge und giftige Tiere wie Ratten, Tausendfüßler, Skorpione, Schlangen, Wespen, Mäuse u. ä. Tiere.

- Tiere, die als abstoßend gelten, wie Eidechsen, Schnecken, Insekten und deren Larvenstadien und andere ähnliche Tiere.

- $\quad$ Tiere, die im Islam nicht getötet werden dürfen, wie Honigbienen und Wiedehopf. 
- $\quad$ Alle giftigen Wassertiere, die gesundheitsschädlich sind, sowie alle Amphibien.

Auch eine Zutat aus den Haram-Tieren sowie Blut und dessen Nebenprodukte sind nicht halal. Ferner dürfen gezüchtete Tiere nicht absichtlich und kontinuierlich mit Haram-Futter gefüttert werden. Haram sind schließlich Tiere, die nicht im Namen Allahs geschlachtet wurden, die nicht nach islamischen Regeln geschlachtet wurden oder die die von selbst gestorben sind, totgeschlagen, erwürgt oder erstickt oder von anderen Tieren getötet wurden sowie kranke Tiere (31).

Für das Schlachten gelten nach islamischem Recht eine Reihe von Vorschriften (20):

- Das Tier, das geschlachtet wird, muss halal sein.

- Die Schlachtung muss durch einen muslimischen Schlachter durchgeführt werden.

- Eine Veterinärbehörde muss durch ein Zertifikat bestätigen, dass das geschlachtete Tier gesund ist.

- Tiere, die geschlachtet werden, müssen zum Zeitpunkt der Schlachtung am Leben sein. Die Schlachtmethode darf bei den Tieren keine Schmerzen und Qualen verursachen. Die Tiere dürfen keinem unnötigen Stress ausgesetzt werden, keine Todesschreie hören und den Schlachtvorgang nicht sehen.

- Das Tier soll in die gemeinsame Gebetsrichtung (Mekka) gerichtet werden, bevor es geschächtet wird.

- Vor der Schächtung muss der Schächter den Namen „Allah” ausrufen.

- Die Halal-Schlachtung ist vollzogen, wenn Luftröhre, Speiseröhre und beide Schlagadern schnell durchschnitten sind.

- Anschließend muss das Tier komplett ausbluten.

Eine traditionelle Schächtung ohne Betäubung ist in der Bundesrepublik Deutschland nur in begründeten Ausnahmefällen unter strengen Auflagen erlaubt; in größerem Umfang ist sie dagegen unter den gegenwärtigen rechtlichen Rahmenbedingungen nicht gestattet. Im europäischen Ausland, z.B. in den Benelux-Staaten, Frankreich und Großbritannien, werden islamische rituelle Schlachtungen hingegen genehmigt.

Eine einheitliche Meinung zur islamkonformen Schlachtung existiert unter den verschiedenen Rechtsschulen der Muslime nicht. Die „,industrielle Schlachtung“ von Tieren, wie sie in Deutschland gängige Praxis ist, wird prinzipiell abgelehnt. Angesichts der hohen Anforderungen an den Tierschutz in Deutschland haben sich viele Muslime gleichwohl damit arrangiert, Betäubungsmethoden bei der Schlachtung zu akzeptieren. So wird eine reversible Betäubung der Tiere, z.B. 
eine elektrische Betäubung mittels der sog. „stunning box”, inzwischen von einigen Rechtsschulen akzeptiert und angewendet. Dabei muss sichergestellt sein, dass die Tiere beim Schlachtvorgang noch am Leben sind und vollständig ausbluten. Das gleiche gilt für die Betäubung per Bolzenschuss, sofern die Tiere sofort danach geschlachtet werden. Eine irreversible Betäubung wird hingegen abgelehnt (23).

Die Berücksichtigung der Halal-Vorschriften bei der Produktion von Lebensmitteln wird üblicherweise durch ein Zertifikat bestätigt. Dieses wird durch auf Halal-Audits spezialisierte Zertifizierer, zum Teil durch große internationale Zertifizierungsunternehmen wie SGS, aber auch durch Moscheen und Islamische Zentren vergeben (23). Die entsprechenden Audits beziehen sich sowohl auf die Zutaten der Produkte als auch den Herstellungsprozess, etwa die Einhaltung der Regeln der islamischen Schlachtung (18). Bei einigen Standards werden weitere Tatbestände, etwa Aspekte der Lebensmittelsicherheit oder das Vorhandensein eines Managementsystems zur Steuerung halal-kritischer Punkte im Verarbeitungsprozess, überprüft. Die Zertifizierung kann im Einzelfall nach verschiedenen Standards erfolgen, die die unterschiedlichen Lehrmeinungen und Richtungen innerhalb des Islam repräsentieren. Der Zertifizierungsmarkt im Bereich der Halal-Lebensmittel ist dadurch insgesamt sehr unübersichtlich (23). In der Gütegemeinschaft Halal-Lebensmittel e.V., Hamburg, haben sich Unternehmen, islamische Vereine und Verbände sowie Halal-Zertifizierer zusammengeschlossen, um die Güte von Lebensmittel, die als halal gekennzeichnet sind, zu sichern und ein einheitliches RAL-Gütezeichen vergeben zu können (www.halal-ral.de).

\section{Methodik und Stichprobe}

Im Juli 2013 wurde eine schriftliche Befragung von 94 dauerhaft oder vorübergehend in Deutschland wohnenden Muslimen mit Hilfe eines standardisierten Fragebogens durchgeführt, um empirische Informationen über die Bedeutung der Halal-Kennzeichnung von Lebensmitteln für die Konsumenten zu erhalten. Die Befragung erfolgte während des Fastenmonats Ramadans in Form von face-to-face-Interviews am Rande des abendlichen Fastenbrechens in der Türkisch Islamischen Gemeinde zu Göttingen e.V. Es handelt sich somit um keine repräsentative Befragung muslimischer Konsumenten in Deutschland, sondern um eine in einer mittelgroßen deutschen Universitätsstadt durchgeführte Erhebung unter Verbrauchern muslimischen Glaubens, die durch das Fasten während des Ramadans und die Teilnahme am Fastenbrechen ihrer Gemeinde bereits zu erkennen gegeben haben, dass für sie die Befolgung der Vorschriften des Koran eine - wenn auch im Einzelfall möglicherweise unterschiedlich große - Bedeutung 
besitzt. Die Befragung erfolgte in türkischer Sprache und wurde erst für die Auswertung in die deutsche Sprache übersetzt. Die empirische Erhebung erstreckte sich im Einzelnen darauf, wie gut den Befragten die Halal-Kennzeichnung vertraut ist und was sie mit ihr verbinden, welcher Stellenwert ihr beim Lebensmittelkauf beigemessen wird und inwieweit die entsprechende Kennzeichnung Auswirkungen auf die Einkaufsstättenwahl hat. Zudem wurde im Wege der direkten Abfrage die Mehrzahlungsbereitschaft für Halal-Produkte erhoben.

Die Befragten sind im Durchschnitt knapp 38 Jahre alt (Standardabweichung $(\sigma)$ : 14,31); der jüngste Befragte war 18, der älteste 78 Jahre alt. 74,5 \% der Befragten waren männlich, 25,5 \% weiblich. Als Herkunftsland geben 78,7\% der befragten Verbraucher die Türkei, 13,8 \% Deutschland und 7,4\% andere ganz überwiegend (u.a. Irak, Pakistan) oder teilweise muslimische Länder (China) an. Die Befragten wohnen im Mittel seit 24,2 Jahren in Deutschland ( $\sigma$ : 11,9); immerhin 31,9\% haben sogar seit 31 oder mehr Jahren ihren Wohnsitz in Deutschland. Das formale Bildungsniveau ist - für Befragungsteilnehmer in einer Universitätsstadt nicht ganz ungewöhnlich - relativ hoch. Immerhin 41,5 \% der Befragten verfügen über einen Universitätsabschluss oder streben diesen als Student gegenwärtig an. 28,7 \% der Befragungsteilnehmer waren zum Erhebungszeitpunkt Studenten, $16 \%$ Angestellte, 26,6\% Arbeiter, je 6,4\% Rentner bzw. erwerbslos, 5,3\% Beamte und 1,1\% Selbstständige (Rest: Sonstiges).

Die Kenntnisse der deutschen Sprache werden von 45,7\% der Befragten als sehr gut, von 23,4 \% als gut, von 25,5\% als mittelmäßig und nur von wenigen Befragten als schlecht $(3,2 \%)$ oder gar nicht vorhanden $(2,1 \%)$ eingestuft. Das Haushaltsnettoeinkommen beträgt im Mittel $1.874 €(\sigma: 993)$. 27,7 \% der Befragten geben das monatliche Haushaltsnettoeinkommen mit weniger als $1.200 €, 43,6 \%$ mit 1.200 bis $2.400 €$ und $28,7 \%$ mit mehr als $2.400 €$ an. $38,3 \%$ der Befragungsteilnehmer sind ausschließlich oder überwiegend für den Einkauf von Lebensmitteln im Haushalt zuständig; $16 \%$ befassen sich nie oder nur selten mit dem Einkauf von Lebensmitteln. Die übrigen Befragten sind teilweise für den Lebensmitteleinkauf im eigenen Haushalt zuständig.

\section{Untersuchungsergebnisse}

Der Bekanntheitsgrad als halal gekennzeichneter Lebensmittel ist unter den befragten Muslimen erwartungsgemäß sehr hoch; 93,6 \% der Befragungsteilnehmer geben an, Halal-Lebensmittel zu kennen. Dieser Wert liegt weit vor den Bekanntheitsgraden aller anderen abgefragten Zertifikate, so etwa von Produkten aus dem Bereich ökologischer Lebensmittel (76,6\%) oder solchen mit qualifizierten geografischen Herkunftsangaben $(51,1 \%)$. Soweit den Befragten die Halal- 
Kennzeichnung bekannt war, wurden sie gebeten, auf einer fünfstufigen Likert-Skala (von 1 = trifft ganz und gar nicht zu bis $5=$ trifft voll und ganz zu) anzugeben, was sie mit diesem Begriff verbinden. Abbildung 1 zeigt, dass die Erwartung, dass die Produkte in Übereinstimmung mit religiösen Geboten erzeugt wurden, deutlich im Vordergrund steht. Zugleich geht damit ein besonderes Vertrauen in die Produkte einher. Ansonsten werden kaum besondere Qualitätseigenschaften, etwa im Hinblick auf Gesundheit oder Genussqualität, mit der Kennzeichnung verbunden.

\section{Abb. 1: Was verstehen die Probanden unter Halal-Lebensmitteln?}

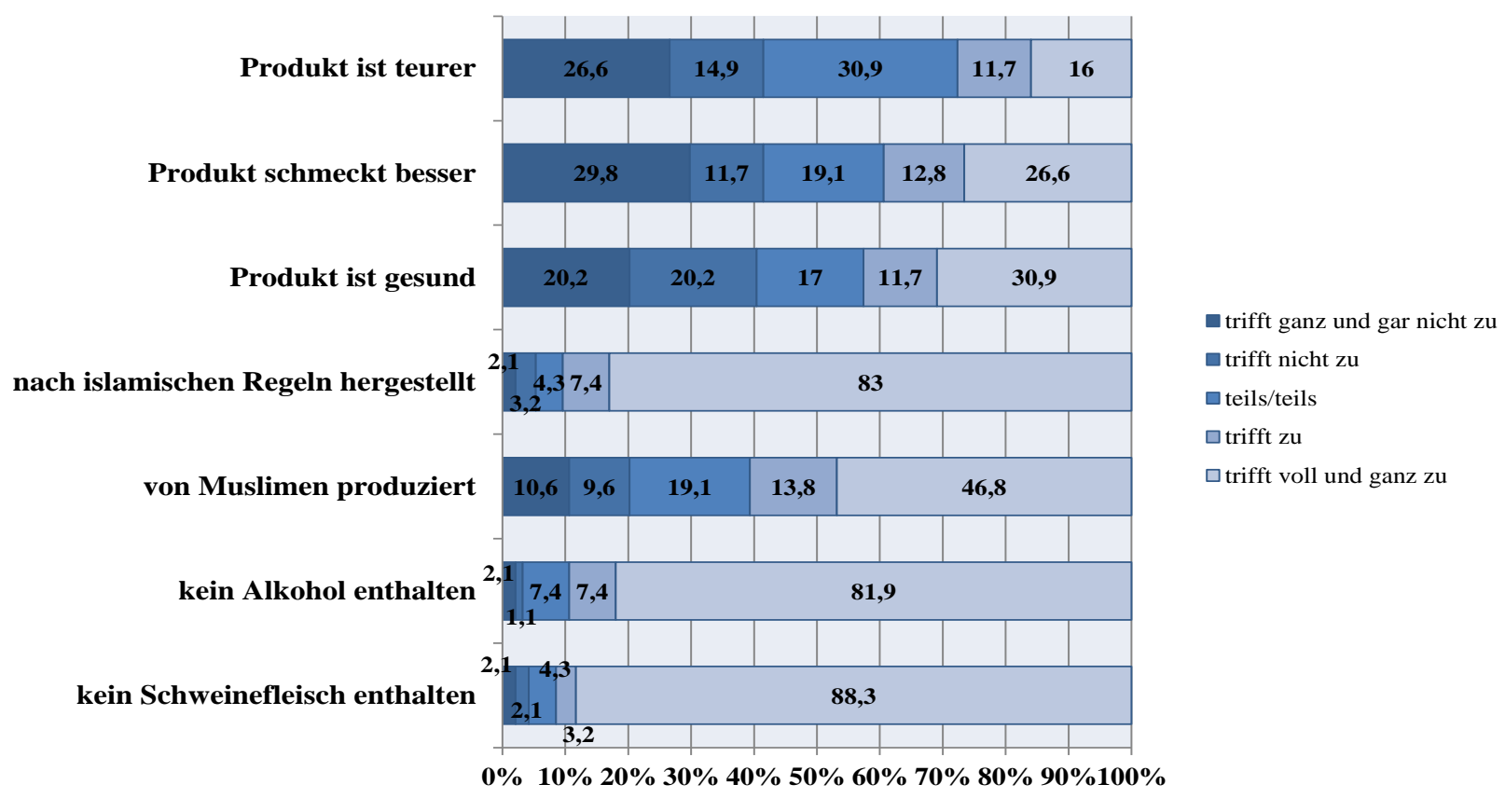

Quelle: Eigene Darstellung

Im Detail zeigt sich mit einem Mittelwert ( $\mu$ ) von 4,73 ( $\sigma)$ : 0.82), dass die große Mehrheit der Befragten angibt, dass Halal-Lebensmittel kein Schweinefleisch enthalten. Ähnlich hohe Mittelwerte weisen die Statements, dass kein Alkohol enthalten ist $(\mu: 4,66 ; \sigma: 0,84)$ und dass das Produkt nach islamischen Regeln hergestellt ist ( $\mu$ : 4,66; $\sigma: 0,87)$, auf. Ein recht hoher Mittelwert von 3,77 ( $\sigma: 1,40)$ weist zudem das Statement ,,von Muslimen produziert“" auf. Bei den weiteren Aussagen, die mehr auf die Produktqualität fokussieren, wie die Einschätzung, dass HalalProdukte gesund seien $(\mu: 3,12 ; \sigma: 1,54)$, besser schmecken würden $(\mu: 2,95 ; \sigma: 1,59)$ oder teurer sind ( $\mu: 2,76 ; \sigma: 1,39)$, zeigt sich eher eine breite Verteilung der Antworten. 
Von einer Zertifizierung von Halal-Lebensmitteln hat der Großteil der Befragten bereits gehört; 79,8\% stimmen dem Statement zu. Dabei haben die meisten Befragten von der HalalZertifizierung im Zusammenhang mit der Produktion von Lebensmitteln in Übereinstimmung mit der Religion ( $\mu$ : 4,40; $\sigma: 1,04$; Skala von 1= trifft ganz und gar nicht zu bis $5=$ trifft voll und ganz zu) oder der Halal-Garantie des jeweiligen Produkts $(\mu: 4,07 ; \sigma: 1,18)$ erfahren. Weiterhin sehen viele Befragte eine Halal-Zertifizierung im Zusammenhang mit der Tatsache, dass sie dem zertifizierten Produkt vertrauen können ( $\mu: 4,02 ; \sigma: 1,22)$. Die Einhaltung von Gesundheit und Qualität der Produktion ( $\mu: 3,55 ; \sigma: 1,40)$ oder eine Verbindung zu einem Naturprodukt $(\mu: 2,85$; $\sigma: 1,510)$ wird der Halal-Zertifizierung zwar nicht ganz so ausgeprägt, aber immer noch recht stark zugesprochen.

Von den Befragten stimmen 92,6\% dem Statement zu oder sogar voll und ganz zu, beim Lebensmittelkauf darauf zu achten, dass die Produkte halal sind. Nur 3,2 \% der befragten Personen charakterisieren das entsprechende Statement als (völlig) unzutreffend; 4,3\% antworteten mit teils/teils. Etwas weniger bedeutsam als die Halal-Eigenschaft ist ein entsprechendes Label bzw. Zertifikat. Hierauf achten nach eigenen Angaben nur 74,5\% der Befragten und damit knapp 20 Prozentpunkte weniger als der Anteil derjenigen, denen die Halal-Eigenschaft beim Lebensmittelkauf wichtig ist. Halal wird quer durch sehr unterschiedliche Produktgruppen eine hohe Bedeutung attestiert; im Fleisch- sowie im Wurstwarenbereich ist diese besonders hoch (Abbildung 2). So weisen Rotfleisch ( $\mu: 4,85 ; \sigma: 0,53)$, Weißfleisch ( $\mu: 4,88 ; \sigma: 0,40)$, Wurstwaren $(\mu: 4,86$; $\sigma: 0,50)$ sowie Döner $(\mu: 4,81 ; \sigma: 0,65)$ allesamt sehr hohe Mittelwerte mit geringen Standardabweichungen auf. Doch auch bei allen weiteren Produkten, die in der Befragung genannt worden sind, wie Joghurt ( $\mu: 4,44 ; \sigma: 0,86)$, Getränke ( $\mu: 4,18 ; \sigma: 1,09)$, Käse $(\mu: 4,56 ; \sigma: 0,82)$, Backwaren $(\mu: 4,45 ; \sigma: 0,89)$, Eis $(\mu: 4,18 ; \sigma: 1,40)$ und Süßwaren $(\mu: 4,36 ; \sigma: 1,01)$ zeigt sich eine deutliche Präferenz für eine Halal-Zertifizierung. 
Abb. 2: Welche Produkte möchten Sie gerne mit einem Halal-Zertifikat kaufen können?

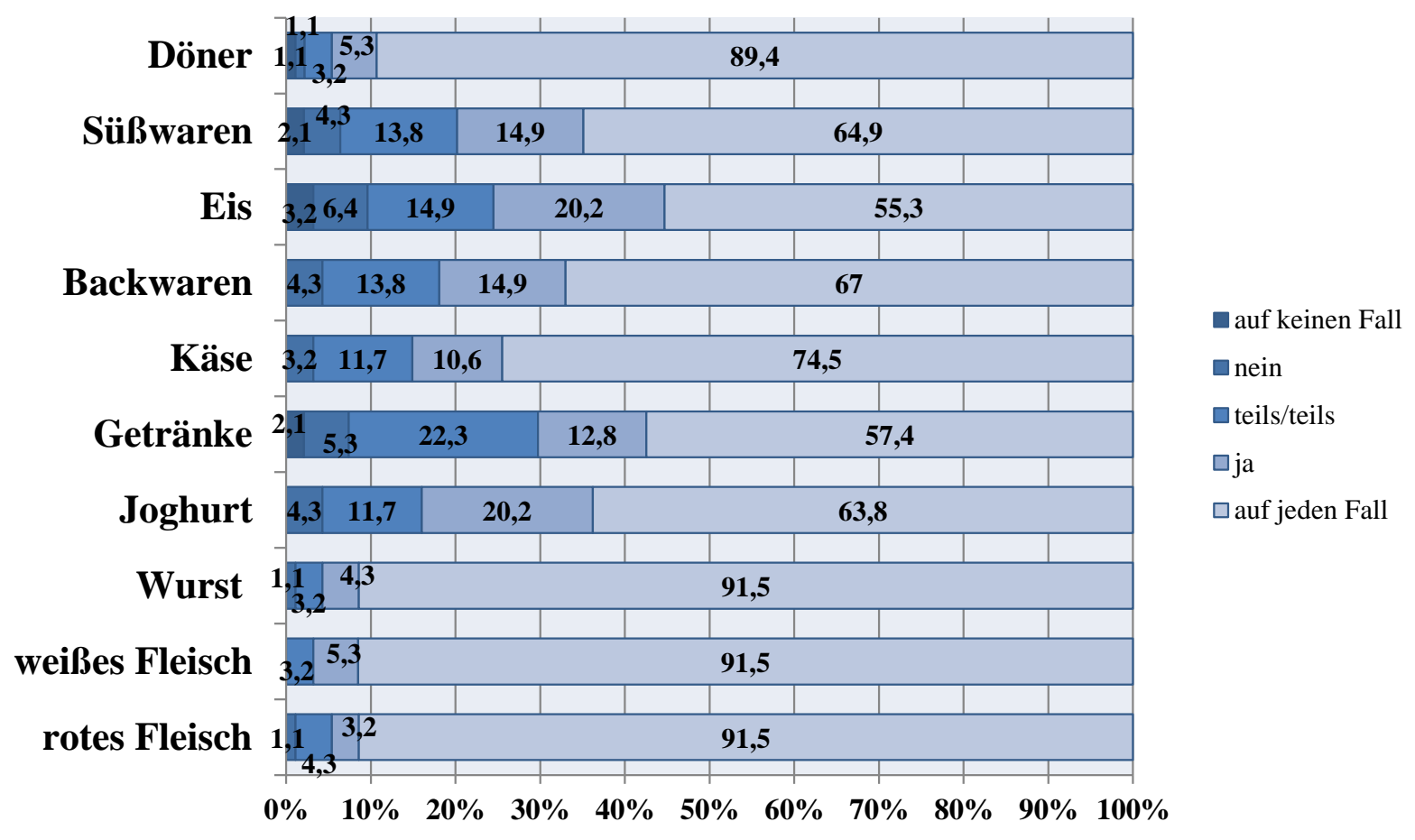

Quelle: Eigene Darstellung

Die Kaufhäufigkeit von halal-gekennzeichneten Lebensmitteln bleibt etwas hinter der wahrgenommenen Bedeutung dieser Produkteigenschaft zurück. So kaufen 11,7 \% der Befragten nie oder nur sehr seltenen Halal-Produkte; $16 \%$ tun es manchmal, 43,6\% gelegentlich und 28,7\% ausschließlich. Auf einer fünfstufigen Likert-Skala (von 1=nie bis 5=immer) erreicht der Mittelwert 3,85 ( $\sigma: 1,06)$, liegt also knapp unterhalb von ,gelegentlichem Kauf“. Die Gründe, die trotz wahrgenommener Bedeutung der entsprechenden Produkteigenschaft dem Kauf von HalalLebensmitteln entgegenstehen, sind in der Befragung nicht eindeutig auszumachen. So erhalten Statements, die sich auf den möglicherweise zu hohen Preis $(\mu: 1,91 ; \sigma: 1,20)$, eine mangelnde Verfügbarkeit der Produkte $(\mu: 2,16 ; \sigma: 1,38)$, mangelndes Vertrauen der Verbraucher in die Kennzeichnung ( $\mu: 2,16$; $\sigma: 1,29)$ oder fehlende Kenntnisse auf Seiten der Konsumenten ( $\mu$ : 1,21; $\sigma: 0,65)$ beziehen, auf einer fünfstufigen Likert-Skala keine oder kaum Zustimmung.

Gegen einen möglicherweise zu hohen Preis als Argument gegen den Kauf von Halal-Produkten spricht auch, dass die Befragten eine positive Mehrzahlungsbereitschaft für Produkte angeben, die den Vorschriften des Islam entsprechen. Die höchsten Mehrzahlungsbereitschaften werden dabei mit durchschnittlich 18,17\% für rotes Fleisch, 17,75\% für weißes Fleisch, 16,09\% für Wurstwaren und 14,64 \% für Döner angegeben. Doch auch bei den weiteren abgefragten Le- 
bensmittel wie Käse (14,96 \%), Backwaren (13,65\%), Joghurt (13,2 \%), Süßwaren (11,88 \%), Eis $(11,60 \%)$ und Getränke $(11,12 \%)$ zeigen die Befragten recht hohe Mehrzahlungsbereitschaften. Auch wenn die Aussagekraft einer direkten Abfrage von Mehrzahlungsbereitschaften gering ist (Attitude-Behaviour-Gap) $(9 ; 15)$, sind die Angaben doch ein Indiz, das gegen eine ausgeprägte Preissensitivität der Verbraucher beim Kauf von Halal-Lebensmitteln spricht.

Interessant ist, dass der hohe Stellenwert, den die Halal-Eigenschaft für die Befragten hat, ihre Einkaufsstättenwahl deutlich zu beeinflussen scheint. Dies gilt insbesondere bei Produkten tierischen Ursprungs, die von den Befragten oft oder immer in muslimischen Geschäften, also im ethnischen oder hybriden ethnischen Einzelhandel (1), nie oder selten dagegen im klassischen Lebensmitteleinzelhandel oder auf Wochenmärkten gekauft werden. So geben große Teile der Befragten an, Wurstwaren (78,7\%), Rotfleisch (76,6\%) sowie Weißfleisch (63,8\%) immer in muslimischen Geschäften zu erwerben. Dagegen besitzen Supermärkte und andere Einzelhändler eine größere Bedeutung als Einkaufsstätte bei Produkten, die offenbar von Menschen, die sich an den Vorschriften des Islam orientieren wollen, als weniger sensibel eingeschätzt werden, so etwa bei Getränken, Backwaren und Süßigkeiten (Tabelle 1).

Tabelle 1: Einkaufsstättenwahl bei Lebensmitteln

\begin{tabular}{|l|r|r|r|r|r|r|r|r|r|r|}
\hline & $\begin{array}{l}\text { rotes } \\
\text { Fleisch }\end{array}$ & $\begin{array}{l}\text { weißes } \\
\text { Fleisch }\end{array}$ & Wurst & Joghurt & $\begin{array}{l}\text { Ge- } \\
\text { tränke }\end{array}$ & Käse & $\begin{array}{l}\text { Back } \\
\text { waren }\end{array}$ & Eis & $\begin{array}{l}\text { Süß- } \\
\text { waren }\end{array}$ & $\begin{array}{l}\text { Döner } \\
\text { Muslimisches } \\
\text { Geschäft }\end{array}$ \\
\hline $\begin{array}{l}\text { Wochen- } \\
\text { markt }\end{array}$ & 1,48 & 4,20 & 4,44 & 3,50 & 2,36 & 3,80 & 3,24 & 1,76 & 2,57 & 4,10 \\
$(1,09$ & $1,33)$ & $(1,24)$ & $1,56)$ & $(1,49)$ & $(1,49)$ & $1,48)$ & $(1,36)$ & $(1,56)$ & $(1,47)$ \\
\hline $\begin{array}{l}\text { Lebens- } \\
\text { mittel- } \\
\text { geschäft }\end{array}$ & $1,51)$ & $(0,55)$ & $(0,41)$ & $(0,78)$ & $(0,93)$ & $(0,78)$ & $(0,74)$ & $(0,83)$ & $(0,75)$ & $(0,48)$ \\
\hline Supermarkt & 1,28 & 1,47 & 1,28 & 2,48 & 2,95 & 2,45 & 2,44 & 2,46 & 2,36 & 1,17 \\
& $(0,69)$ & $(1,34)$ & $(0,58)$ & $(1,53)$ & $(1,33)$ & $(1,47)$ & $(1,41)$ & $(1,50)$ & $(1,56)$ & $(0,60)$ \\
\hline Hersteller & 1,66 & 1,33 & 1,18 & 1,31 & 1,34 & 1,24 & 1,60 & 1,73 & 1,36 & 1,23 \\
& $(1,26)$ & $(0,89)$ & $(0,69)$ & $(0,82)$ & $(0,91)$ & $(0,76)$ & $(1,19)$ & $(1,39)$ & $(0,97)$ & $(0,81)$ \\
\hline Sonstige & 1,02 & 1,05 & 1,01 & 1,07 & 1,06 & 1,02 & 1,09 & 1,11 & 1,07 & 1,12 \\
& $(0,15)$ & $(0,42)$ & $(0,10)$ & $(0,34)$ & $(0,32)$ & $(0,15)$ & $(0,52)$ & $(0,54)$ & $(0,45)$ & $(0,62)$ \\
\hline
\end{tabular}

Mittelwerte, in ( ) = Standardabweichung; Skala von 1: kaufe ich gar nicht dort ein bis 5: kaufe ich immer dort ein Quelle: Eigene Darstellung 


\section{Diskussion und Schlussfolgerungen}

Die Präferenzen und die Einkaufsstättenwahl von Bürgern mit Migrationshintergrund sowie Besonderheiten ihres Einkaufsverhaltens sind in Deutschland lange Zeit nur vereinzelt Gegenstand empirischer Untersuchungen gewesen $(6 ; 34 ; 24 ; 1 ; 25)$. In anderen Ländern, die schon eher als Deutschland den Status von Einwanderungsländern erlangt hatten, etwa den USA, sind entsprechende Studien dagegen bereits deutlich früher und in größerer Zahl durchgeführt worden (z.B. 32; 30; 14). In jüngerer Zeit finden diese Arbeiten unter dem Begriff des Ethno-Marketing verstärkt Anschluss an den Mainstream der betriebswirtschaftlichen Forschung (35; 8). Trotz der verstärkten Hinwendung zu den genannten Fragestellungen ist insgesamt noch eine erhebliche Forschungslücke im Hinblick auf die Erklärung des Kaufverhaltens einer großen Bevölkerungsgruppe zu konstatieren, zu deren Schließung der vorliegende Artikel beiträgt.

Im Kern stimmen die Ergebnisse der hier vorgestellten Befragung mit bereits vorliegenden Untersuchungsergebnissen überein. So haben auch frühere Studien gezeigt, dass Muslime eine besondere Vorsicht beim Kauf von Produkten walten lassen, bei denen die Gefahr besteht, dass die Rezepturen oder Herstellungsverfahren in einer mehrheitlich nicht-muslimischen Gesellschaft im Konflikt mit den Vorschriften des Islam stehen könnten; dies gilt etwa im Hinblick auf die Verwendung von Schweinefleisch oder Gelatine vom Schwein. Ebenso wird - wiederum in Übereinstimmung mit früheren Studien - deutlich, dass der Wunsch nach Einhaltung religiöser Vorschriften ein Grund für die Bevorzugung des ethnischen bzw. hybriden ethnischen Einzelhandels sein kann (1).

Für den (hybriden) ethnischen Einzelhandel wird ersichtlich, dass er durch das besondere Augenmerk, das er vielfach auf die Halal-Eigenschaft der vertriebenen Lebensmittel legt, einen Wettbewerbsvorteil gegenüber dem klassischen Lebensmitteleinzelhandel in Deutschland hat. Dies gilt namentlich für die Produktgruppen, die von Muslimen als besonders sensibel im Hinblick auf die Einhaltung der Vorschriften des Islams eingeschätzt werden. Hier wird sich zeigen, ob dieser Wettbewerbsvorteil auch bei Einwanderern der dritten und vierten Generation weiter bestehen bleibt, oder ob es insoweit zu Assimilationserscheinungen kommt, die diese Unique Selling Proposition an Wert verlieren lassen. Ähnliches ist vielen in der früheren DDR beheimateten Marken widerfahren, die anfangs wegen ihrer Herkunft namentlich von ostdeutschen Konsumenten besonders geschätzt wurden, nach und nach aber diesen Wettbewerbsvorteil einbüßten, da vor allem jüngere Konsumenten der ostdeutschen Herkunft zunehmend weniger Bedeutung beimaßen (33). 
Für die Lebensmittelindustrie wie auch den klassischen Einzelhandel sind die Ergebnisse ebenfalls interessant. So bietet sich der Lebensmittelwirtschaft ein großes zusätzliches Marktsegment, in dem der Marktanteil von Produkten, die aus den Herkunftsländern der (ersten Generation der) Migranten importiert werden bzw. durch hiesige Niederlassungen von Lebensmittelverarbeitern aus diesen Ländern erzeugt werden, bislang sehr hoch ist. Das zunehmende Interesse der Ernährungswirtschaft an Halal-Zertifizierungen (23) zeigt, dass dieses im In- und Ausland bedeutsame Marktsegment erkannt wurde und zunehmend aktiver bearbeitet wird. Für den klassischen Lebensmitteleinzelhandel wiederum stellt sich die Frage, wie der insoweit bestehende Wettbewerbsnachteil gegenüber dem (hybriden) ethnischen Einzelhandel im Hinblick auf das Angebot zielgruppengerechter Halal-Produkte aufgeholt werden kann. Hier wären zumindest bei Produkten des täglichen Bedarfs Ergänzungen des bisherigen Warenangebots denkbar. Insoweit hat ohne Zweifel der großflächige Einzelhandel, etwa Verbrauchermärkte, Vorteile gegenüber den mit einer geringeren Produktvielfalt operierenden Discountern.

Für die weitere Forschung bieten sich verschiedene Ansatzpunkte. So könnten zukünftige Studien vertiefte Einblicke in das Einkaufsverhalten muslimischer Konsumenten in Deutschland vermitteln. Insbesondere liegen noch kaum Erkenntnisse zur kulturellen Prägung des Einkaufsverhaltens bei Einwanderern der dritten oder gar vierten Generation vor. Aus Sicht des klassischen Lebensmitteleinzelhandels wiederum wäre es interessant $\mathrm{zu}$ wissen, wie nichtmuslimische Verbraucher auf eine systematische Ergänzung des Angebots um Halal-Produkte reagieren würden. Schließlich ist halal eine Vertrauenseigenschaft (11), deren Vorliegen durch die Konsumenten nicht zuverlässig beurteilt werden kann. Das Vertrauen der Verbraucher in Verarbeiter und Handel, aber auch in die die Halal-Zertifikate erteilenden Zertifizierungsunternehmen ist daher von besonderer Bedeutung (23). Hier wäre es aufschlussreich zu erfahren, wie groß diesbezügliche Unterschiede z.B. zwischen dem ethnischen bzw. hybriden ethnischen Einzelhandel einerseits und dem klassischen Lebensmitteleinzelhandel andererseits von muslimischen Verbrauchern wahrgenommen werden.

\section{Zusammenfassung}

Auch wenn aktuell keine genauen amtlichen Zahlen über die Anzahl der in Deutschland lebenden Muslime existieren, so kann von schätzungsweise über 4 Mio. Menschen ausgegangen werden, die dem muslimischen Glauben angehören. Für diese gelten aus religiöser Tradition verschiedene Speisevorschriften, die unter anderem den Verzehr von Schweinefleisch verbieten. Eine Halal-Kennzeichnung signalisiert Muslimen, dass sie die entsprechenden Produkte unbe- 
sorgt kaufen können, da bei ihrer Herstellung die islamischen Vorschriften eingehalten wurden. Vor diesem Hintergrund sind im vorliegenden Beitrag 94 dauerhaft oder vorübergehend in Deutschland wohnende Muslime über ihr Einkaufsverhalten befragt worden. Es zeigt sich, dass eine Halal-Kennzeichnung einen großen Stellenwert für die Befragten hat und sie vor allem bei tierischen Produkten einen hohen Bedarf an einer entsprechenden Kennzeichnung sehen. Ferner deutet sich ein Einfluss der Halal-Kennzeichnung auf die Zahlungsbereitschaft von Konsumenten an und werden Auswirkungen auf die Einkaufsstättenwahl sichtbar.

\section{Summary}

Although currently no accurate official figures on the number of Muslims living in Germany exist, it can be assumed that approximately more than 4 mil. people who live in Germany belong to the Muslim faith. For them, due to their religious tradition, different dietary laws that forbid the consumption of pork among others exist. A halal label signals the Muslims that they can buy the appropriate products safely, because during their preparation, the Islamic rules have been complied with. Against this background, 94 Muslims living in Germany have been asked about their purchasing behavior in this article. It turns out that a halal label has a great importance for the respondents, particularly concerning animal products. Furthermore, the respondents reveal a positive willingness to pay for halal food and choose retail outlets with regard to the availability of halal food.

\section{Résumé}

Bien qu'il n'existe actuellement de chiffres officiels précis sur le nombre de musulmans vivant en Allemagne, on estime que plus de 4 mio. de personnes sont de religion musulmane.

Pour ces personnes comptent des règles alimentaires précises, interdisant par exemple la consommation de viande de porc. Afin de faciliter l'achat de nourriture conforme aux recommandations des musulmans, un débat est ouvert sur un label «Halal», qui signaliserait aux musulmans l'achat sans crainte des produits appropriés, garantissant une production conforme aux règles islamiques. Dans ce contexte, au cours des recherches, 94 personnes musulmanes vivant en Allemagne ont été interrogée sur leur comportement d'achat. Il en découle que les participants ont accordé une grande importance à un éventuel label «Halal» surtout dans le domaine des produits animaux. 


\section{Literatur}

1. AYGÜN, T. (2005): Deutschtürkisches Konsumentenverhalten. Eine empirische Untersuchung zur Einkaufsstättenwahl im Lebensmitteleinzelhandel. Lohmar und Köln, Eul Verlag.

2. BARLÖSIUS, E. (1999): Soziologie des Essens. München, Weinheim.

3. De Castro, J.M., Bellisle, F., Feunekes, G.I.J., Dalix, A.M. und De GraAf, C. (1997): Culture and Meal Patterns: A Comparison of the Food Intake of Free-living American, Dutch, and French Students. In: Nutrition Research, 17. Jg., S. 807-829.

4. Egeler, R. (2013): Pressekonferenz „Zensus 2011 - Fakten zur Bevölkerung in Deutschland“" am 31.05.2013 in Berlin. URL: https://www.destatis.de/DE/PresseService/Presse/ Pressekonferenzen/2013/Zensus2011/Statement_Egeler_zensus_PDF.pdf?_blob=publica tionFile. Stand: 23.10.2013.

5. EHZ (2010): Europäisches Halal Zertifizierungsintitut (Hrsg): Halal Richtlinien für die Halal-Zertifizierung, Hamburg.

6. ERdÖNMEZ, H. und LuTTERMANN-SEMMER, E. (1999): Ernährungsgewohnheiten von in Deutschland lebenden türkischen Migranten. In: DGE-info, H. 9, S. 132-134.

7. Evans, M., Jamal, A. und Foxall, G. (2006): Consumer Behavior. 2. Aufl., Chichester, Wiley.

8. GERPOTT, T.J. und BICAK, I. (2011): Ethno-Marketing: Synopse empirischer Studien sowie Schlussfolgerungen für die Marketing-Praxis und -Forschung. In: Der Markt, 50. Jg., S. $97-$ 108.

9. GuPta, S.; OGden, D. T. (2006): The Attitude-Behaviour Gap in Environmental Consumerism. Paper presented at the $29^{\text {th }}$ annual meeting of the Association of Pennsylvania University Business and Economics Faculty (APUBEF), State College Pennsylvania.

10. Halal Congress (2012): Halal: Global standard for Quality, Hygiene and Safety, Halal Congress Middle East, 11.-12. December 2012, Export Centre Sharjah, UAE, (www.HalalCongress.com).

11. HANF, C.-H. (2000): Zur Bedeutung von Vertrauenseigenschaften für den Wettbewerb auf Lebensmittelmärkten. In: von Alvensleben, R., Koester, U. und Langbehn, C. (Hrsg.): Wettbewerbsfähigkeit und Unternehmertum in der Land- und Ernährungswirtschaft. Schriften der Gesellschaft für Wirtschafts- und Sozialwissenschaften des Landbaues e.V., Bd. 36. Münster-Hiltrup, Landwirtschaftsverlag, S. 265-271.

12. HIRSCHFELDER, G. (2001): Europäische Esskultur. Eine Geschichte der Ernährung von der Steinzeit bis heute. Frankfurt a. Main, Campus Verlag.

13. KARAKOC, Ö. (2012): Halal Food Certification, New approaches at comformity assessment. Turkish Standards Institution, Ankara.

14. KIM, Y.-K. und HAN, S. (2000): Perceived Images of Retail Stores and Brands: Comparison among three Ethnic Consumer Groups. In: Journal of Family and Consumer Sciences, 92. Jg., Nr. 3, S. 58-61.

15. Kollmuss, A. und AgYeman, J. (2002): Mind the Gap: why do people act environmentally and what are the barriers to pro-environmental behaviour? In: Environmental Education Research 8 (3). S. 239-260. 
16. KrÖBer-RIEL, W., WeInBERG, P. und GRÖPPEL-Klein, A. (2008): Konsumentenverhalten. 9. Aufl., München, Vahlen.

17. OIC (2009): OIC Standards - general guidelines on Halal food. URL: http://www.halal world.org/download/standard/filegallery/47/OIC\%20Standards-General\%20Guidelines\% 20on\%20Hala1\%20Food.pdf.

18. ÖzoguZ, Y. (2011): Halal-Speise im deutschsprachigen Raum. Eine Einführung für Verbraucher, Betriebe und Zertifizierer. Bremen, m-haditec.

19. O.V. (2013): Etwa 4 Millionen Muslime in Deutschland. URL. http://www.deutsche-islamkonferenz.de/DIK/DE/Magazin/Lebenswelten/ZahlMLD/daten-und-fakten1-hiddennode.html. Stand: 23.10.2013.

20. QFC (2011): Halal-Zertifizierung nach QFC. Erschließung neuer Märkte. DNV Business Assurance. URL: http://www.dnvba.com/de/DNV\%20\%20Downloads/Whitepaper_ Halal_final_rev\%201.

21. RiAz, M.N. und Chaudry, M.M. (2004): Halal food production in CRS Press LLC, Florida.

22. ScheIN, E.H. (1992): Organizational Culture and Leadership. 2. Aufl., San Francisco, Jossey Bass.

23. Schlossberger, F. (2011): Mit Halal-Food neue Märkte erschließen. IEMVeröffentlichung, Bayerische Landesanstalt für Landwirtschaft, München.

24. Schmid, B. (2003): Ernährung und Migration. Empirische Untersuchungen zum Ernährungsverhalten italienischer, griechischer und türkischer Migrantinnen in Deutschland. München, Herbert Utz Verlag.

25. Schneider, H., Coskun, B., Kelemci Schneider, G. (2010): Rollenverteilung bei Kaufentscheidungen türkischstämmiger Familien in Deutschland. In: Marketing ZFP, 32. Jg. S. 164-179.

26. Sekretariat der Deutschen Bischofskonferenz (2003): Christen und Muslime in Deutschland. Arbeitshilfen 172, 23. September 2003, Bonn.

27. SMIIC (2012): Report for $28^{\text {th }}$ Meeting of COMCEC. The Standards and Metrology Institute for Islamic Countries (SMIIC), Istanbul, Türkei.

28. Statistisches BundeSAMt (2013a): URL: https://www.destatis.de/DE/ZahlenFakten/ GesellschaftStaat/Bevoelkerung/MigrationIntegration/Migrationshintergrund/ Aktuell.html. Stand: 23.10.2013.

29. Statistisches Bundesamt (2013b): URL: https://www.destatis.de/DE/Presse Service/Presse/Pressemitteilungen/2012/09/PD12_326_122.html. Stand: 23.10.2013.

30. Stayman, D.M. und DeshPande, R. (1989): Situational Ethnicity and Consumer Behavior. In: Journal of Consumer Research, 16. Jg., S. 361-371.

31. TAuber, J. (2011): Halal - Erlaubt und Zulässig. Der Islam und seine Vorschriften. In: Hygiene Report 2/2011, S. 18-22. 
32. Wallendorf, M. und Reilly, M.D. (1983): Ethnic Migration, Assimilation and Consumption. In: Journal of Consumer Research, 10. Jg., S. 292-302.

33. WiCHERT, G. v. (2007): Markenimages von Konsumgüterherstellern bei Jugendlichen. Studie des Conomic TrendLab. Halle/Saale.

34. WiNKLER, G. (2003): Ernährungssituation von Migranten in Deutschland - was ist bekannt? Teil 2: Ernährungsverhalten. In: Ernährungs-Umschau, 50. Jg., H. 6, S. 119-121.

35. WÜNSCHE, R. (2009): Ethno-Marketing: Interkulturelle Aspekte. Hamburg, Igel Verlag. 


\section{Fazit und Ausblick}

Die Bedeutung von Qualität und Zertifizierung ist in der türkischen Agrar- und Ernährungswirtschaft in den letzten Jahren stetig gewachsen. Die steigende Internationalisierung und der zunehmende Konkurrenzdruck, der vor allem mit der steigenden Anzahl der Beschaffungs- und Absatzmärkte sowie nicht zuletzt den engen handelspolitischen Verflechtungen der Türkei mit der Europäischen Union einhergeht, sind bereits genügend Gründe für eine Qualitätssicherung durch staatliche und private Standards. Insofern stellen Qualitätssicherungssysteme eines der entscheidenden Differenzierungsmerkmale in den globalen Kunden-Lieferanten-Beziehungen sowie der Lebensmittelsicherheit für Verbraucher dar.

Trotz zahlreicher neuer Entwicklungen in der türkischen Agrar- und Ernährungswirtschaft gibt es leider noch immer kritische Schwachstellen im Bereich der Lebensmittelsicherheit und der Qualitätssicherungssysteme. Obwohl es inzwischen recht zahlreiche wissenschaftliche Arbeiten zur Thematik der Agrar- und Ernährungswirtschaft in Schwellen- und Entwicklungsländer gibt, sind viele Problemstellungen auch weiterhin ungelöst; beispielsweise wurde die Implementierung von Qualitätssicherungssystemen durch türkische Unternehmen nach unserem Kenntnisstand nach wie vor nicht untersucht.

In der vorliegenden Dissertationsschrift werden die inzwischen etablierten Systeme in der türkischen Agrar- und Ernährungswirtschaft zur Qualitätssicherung bei Agrarprodukten und Lebensmitteln vorgestellt. Besondere Beachtung finden die Einflussgrößen auf die Zertifizierungsentscheidungen und die Wahrnehmung von Zertifizierungssystemen sowie die Qualitätsanforderungen im türkischen Agribusiness. Abschließend wird der Fokus auf die Halal- bzw. HelalZertifizierung aus Sicht des deutschen Verbrauchers gelegt.

Die Einleitung umreißt zum einen die wissenschaftliche Fragestellung, geht aber auch auf die EU-Beitrittsverhandlungen mit der Türkei ein. Die Darstellung der türkischen Agrarwirtschaft mit ihren unterschiedlichen Strukturen, den räumlichen Verteilungen, den Im- und Exporten, dem Produktionsspektrum sowie den internationalen Verflechtungen wurden mit Hilfe der offiziellen türkischen Statistik ausgewertet. Im zweiten Hauptkapitel des ersten Teils werden die Grundzüge des Lebensmittelrechts sowie die Verbreitung von Zertifizierungssystemen in der Türkei nach nationalen und internationalen Standards beschrieben.

Teil II widmet sich den Determinanten für die Annahme der Qualitätssicherungssysteme durch Unternehmen der türkischen Agrar- und Ernährungswirtschaft. Es wurde versucht, eine Antwort 
auf die Frage nach der Beziehung zwischen dem Grad der Annahme der Qualitätssicherungssysteme und den Unternehmensmerkmalen zu finden. $\mathrm{Zu}$ den Unternehmensmerkmalen gehören Eigentum und Kontrolle, Internationalisierungsgrad, Unternehmensgröße, Verarbeitungszweige usw. Außerdem stehen mit den Unternehmensmerkmalen noch weitere Aspekte im Zusammenhang. Berücksichtigt werden müssen z.B. auch die Wettbewerbsstrategie, die Wahrnehmung der Qualitätsanforderungen der Europäischen Union sowie die Einschätzung der durch die Zertifizierung verursachten Mehrkosten als Einflussgrößen auf die Entscheidungen von Unternehmen zur Implementierung von Qualitätssicherungssystemen.

Dieser Teil der Dissertation beschäftigt sich mit verschiedenen Verarbeitungszweigen, staatlichen und privaten Standards. Dafür wurden zahlreiche Teilnehmer befragt und verschiedene Studien miteinander verglichen. Die empirische Analyse zeigt u.a., dass die Rechtsform der Unternehmen, die Absatzmärkte und der jeweilige Sitz der Unternehmen einen Einfluss auf die Zertifizierungsentscheidung haben. Auch die Unternehmensgröße und die mögliche Auslandstätigkeit haben großen Einfluss auf die Einführung von Qualitätssicherungssystemen.

Es hat sich, auch anhand vorheriger Studien, übereinstimmend herausgestellt, dass größere Unternehmen (mehr als 100 Mitarbeiter) eher daran interessiert sind, Lebensmittelsicherheits- und Qualitätssicherungssysteme für ihr Unternehmen einzuführen. Überraschenderweise spielen in unserem Modell weder die Einführung von Lebensmittelsicherheits- und Qualitätssicherungssystemen noch die Wettbewerbsstrategie oder die zusätzlichen Kosten, die die Einführung von Zertifizierungssystemen mit sich bringt, eine Rolle. Auch die Beziehung zwischen der jeweiligen Wahrnehmung der EU-Anforderungen durch die Befragten und der Annahme der Qualitätssicherungssysteme ist nicht signifikant. Die Aktiengesellschaften verfügen dagegen über mehr Qualitätssicherungssysteme als andere Unternehmensrechtsformen.

MENA-Länder-Exporteure (Naher Osten und Nordafrika) sind eher weniger an der Umsetzung von Zertifizierungssystemen interessiert, da es sich vielfach um Länder mit geringerer Kaufkraft handelt. Diese Verbraucher stellen im Vergleich mit den EU-Ländern keine so hohen Anforderungen; deshalb ist davon auszugehen, dass die MENA-Länder für viele türkische Unternehmen des Agribusiness weiterhin an Attraktivität gewinnen werden. Man kann also durchaus feststellen, dass der EU-Markt nicht unbedingt bei allen Unternehmen Priorität hat. Aber offensichtlich haben Zertifizierungssysteme auch bei türkischen Unternehmen des Agribusiness durchaus einen hohen Stellenwert. 
Im zweiten Beitrag wurde der Fokus auf einen anderen Bereich gelegt. Hier wird angeknüpft an den offiziellen Status der Türkei als Beitrittskandidat zur Europäischen Union, der dem Land bereits 1999 verliehen wurde. Im Jahre 2005 wurden schließlich die Beitrittsverhandlungen eröffnet und es wurde mit den damit verbundenen Anpassungsprozessen im türkischen Lebensmittelrecht begonnen. Wovon hängt es eigentlich $\mathrm{ab}$, ob türkische Lebensmittelverarbeiter bereit sind, den Anforderungen nachzukommen, denen sie auf ihrem oftmals wichtigsten Exportmarkt, der Europäischen Union, unterliegen? Wird die zunehmende Angleichung des türkischen Gesetzgebers an die Lebensmittelsicherheit der EU eher als Chance oder als Risiko wahrgenommen? Diese Fragen stellen sich und es zeigt sich, dass verschiedene Determinanten Einfluss auf die Wahrnehmung der lebensmittelrechtlichen Anforderungen durch die Unternehmen haben. Im Einzelnen sind dies unterschiedliche Merkmale der Befragten, die sowohl ihr Wissen als auch ihre persönliche Perspektive bestimmen (objektive Informationen). Besonders spielen hier die Bildung, das Alter, das Geschlecht und der Beruf eine große Rolle. Zu den objektiven Merkmalen der Unternehmen gehören u.a. die Unternehmensgröße, der Internationalisierungsgrad, der Standort des Unternehmens, die Unternehmensbranche, die Absatzmärkte usw. sowie auch die subjektiven Einschätzungen der Befragten. All diese Faktoren wurden genutzt, um Aussagen etwa hinsichtlich zusätzlich entstehender Kosten, der Wettbewerbsstrategie des eigenen Unternehmens, wahrgenommener Vor- und Nachteile der rechtlichen Anforderungen und den Zertifizierungsgründen zu machen. Die Ergebnisse zeigen, dass die EU-Anforderungen sehr unterschiedlich wahrgenommen werden, abhängig von der Ausbildung der Befragten, der Unternehmensgröße und der Rechtsform der Unternehmen.

Es ergeben sich interessante Fragestellungen für weitere Forschungsvorhaben, etwa zum Zusammenhang der Qualitätssicherung mit wirtschaftlichen Leistungsindikatoren (z.B. Rentabilität, Multifaktorproduktivität, Kosten und Reputation). Aufschlussreich wären auch Einblicke in die weiteren Entwicklungen sowie neue Trends in Bezug auf Lebensmittelsicherheits- und Qualitätssicherungssysteme.

Der letzte Einzelbeitrag befasst sich mit der Halal- bzw. Helal-Zertifizierung. Hier werden die Konsumgewohnheiten und das Kaufverhalten der muslimischen Konsumenten in Deutschland herausgearbeitet. Was verbinden die befragten muslimischen Verbraucher in Deutschland mit der Halal-Zertifizierung, was verstehen sie unter Halal-zertifizierten Lebensmitteln, wie wichtig sind ihnen bei den unterschiedlichen Agrarprodukten und Lebensmitteln die evtl. Konsequenzen einer Halal-Zertifizierung und was ergibt sich aus der wahrgenommenen Bedeutung dieser Zerti- 
fizierung für die Einkaufsstättenwahl? Dieser Beitrag bezieht sich nicht nur auf das internationale Ethno-Marketing, es handelt sich auch um neue Einsichten für türkische Exporteure, da die Halal-Zertifizierung besonders in letzter Zeit in der Türkei zu einem neuen Trend geworden ist.

Insgesamt fiel bei der Umfrage im türkischen Agribusiness auf, dass türkische Unternehmer und Hersteller nicht an Face-to-face Interviews gewöhnt sind und zudem auch wenig Erfahrung mit Online-Befragungen haben. Dies stellte eine wesentliche Herausforderung für die Datenerhebung dar. Es ist zu hoffen, dass sich das in der näheren Zukunft ändert. Daher sollte der Fokus für künftige empirische Marktforschungsuntersuchungen stärker bei der Face-to-face-Befragung liegen, um die Unternehmen mit dieser Form der Datenerhebung vertraut zu machen und quasi einen Gewöhnungseffekt zu erzielen.

Ein längerfristiges Ziel der vorliegenden Dissertation ist es, dass die Ergebnisse der vorliegenden Arbeit u.a. Auswirkungen auf die Einstellungen von Führungskräften sowie politischen Entscheidungsträgern in der Türkei haben. Entsprechende Veränderungen würden wesentlich dazu beitragen, die Voraussetzungen für einen möglichen künftigen EU-Beitritt der Türkei zu schaffen. 


\section{Anhang:}

1. Fragebogen für Qualitätssicherungssysteme in der türkischen Agrar- und Ernährungswirtschaft

2. Deskriptive Ergebnisse

3. Fragebogen zum Konsumverhalten von Muslimen in Deutschland bei Halal-Lebensmitteln: Fallbeispiel Göttingen 


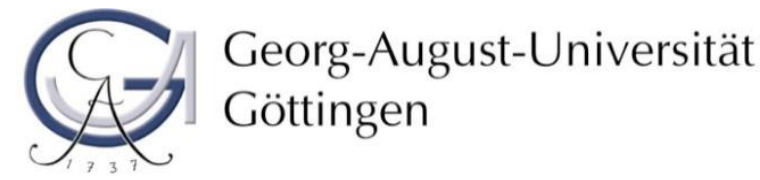

Prof. Dr. L. Theuvsen · Department für Agrarökonomie und Rurale Entwicklung Platz der Göttinger Sieben 5-D-37073 Göttingen

Ihre Nachricht vom

Unsere Nachricht vom

Ihr Zeichen

Unser Zeichen

\section{Datenerhebung Tuba Pekkirbizli}

Sehr geehrte Damen und Herren,

Frau Tuba Pekkirbizli fertigt gegenwärtig ihre Dissertation an der Georg-August-Universität Göttingen an. Sie befasst sich mit dem Thema "Qualitätssicherungssysteme in der türkischen Agrar- und Ernährungswirtschaft". Aus diesem Grund führt sie eine empirische Erhebung bei türkischen Unternehmen der Ernährungswirtschaft durch.

Für aussagefähige Ergebnisse sind Informationen aus der Praxis unerlässlich. Daher wäre ich Ihnen sehr dankbar, wenn Sie Frau Pekkirbizli bei Ihrem wissenschaftlichen Vorhaben unterstützen und den beiliegenden Fragebogen für Ihr Unternehmen soweit wie möglich beantworten würden.

Jede einzelne Antwort trägt zum Gelingen des Projektes bei. Bitte füllen Sie den Fragebogen auch dann aus, wenn Sie unter Umständen nicht alle Fragen beantworten können oder wollen. Bei Rückfragen steht Ihnen Frau Pekkirbizli gerne zur Verfügung.

Wir versichern Ihnen, dass alle Angaben streng vertraulich behandelt werden.

Vielen Dank für Ihre Unterstützung.

Mit freundlichen Grüßen

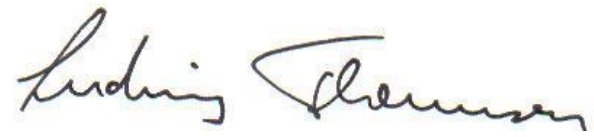

(Prof. Dr. Ludwig Theuvsen) 


\begin{tabular}{|l|l|}
\hline Ausfülldatum des Fragebogens: & $-/{ }^{2013}$ \\
\hline Startzeit: & - : U Uhr \\
\hline
\end{tabular}

\section{Teil 1: Allgemeine Fragen}

1.

\begin{tabular}{|l|c|c|}
\hline Ist Ihr Unternehmen im Ausland tätig? & Ja $\square$ & Nein $\square$ \\
\hline
\end{tabular}

2. Welche Rechtsform hat Ihr Unternehmen?

\begin{tabular}{|l|l|}
\hline$\square$ Limited Company & $\square$ Collective Company \\
\hline$\square$ Joint Stock Company & $\square$ andere, und zwar: \\
\hline$\square$ Kommandite Company & \multicolumn{1}{|l}{} \\
\cline { 1 - 2 } &
\end{tabular}

3. In welcher Region befindet sich der Sitz Ihres Unternehmens? (Bitte wählen Sie aus der Liste; mehrere Antworten sind möglich.)

\begin{tabular}{|l|c|l|c|}
\hline Zentralanatolien & $\square$ & Südost-Anatolien & $\square$ \\
\hline Mittelmeer-Region & $\square$ & Marmara-Region & $\square$ \\
\hline Ägäische Region & $\square$ & Schwarzmeer-Region & $\square$ \\
\hline Ost-Anatolien & $\square$ & \multicolumn{2}{|l}{} \\
\cline { 1 - 2 } & &
\end{tabular}

4. Handelt es sich bei Ihrem Unternehmen um einen verarbeitenden Betrieb? (Bitte kreuzen Sie das für Ihren Betrieb passende an.)

\begin{tabular}{|l|l|l|}
\hline$\square$ Süß,- Schokoladenwaren & $\square$ Obst- und Gemüseverarbeitung & $\square$ frisches Obst und Gemüse \\
\hline$\square$ Back- und Teigwaren & $\square$ Schlachten und Fleischverarbeitung & $\square$ Fette und Öle \\
\hline$\square$ Hülsenfrüchte und Getreide & $\square$ alkoholhaltige Getränke & $\square$ Tee und Kräutertees \\
\hline$\square$ Mahl- und Schälmühlen & $\square$ alkoholfreie Getränke & $\square$ Milchverarbeitung \\
\hline$\square$ getrocknetes Obst & $\square$ Stärke und Stärkeerzeugnisse & $\square$ Tomatenmark und Tomaten \\
\hline$\square$ getrocknetes Gemüse & $\square$ Öl-Saaten & $\square$ Nüsse und Nuss-Erzeugnisse \\
\hline$\square$ Eier & $\square$ Gewürze & $\square$ Geflügelfleisch \\
\hline$\square$ Meeresfrüchte & $\square$ Inhaltsstoffe & $\square$ Kaffee \\
\hline$\square$ Futtermittelproduktion & $\square$ Sonstiges: & \\
\hline
\end{tabular}


Teil 2: Handelsbeziehung, Marketing und Export

5.

\begin{tabular}{|l|c|}
\hline Handelt es sich um ein Familienunternehmen? & Ja $\square$ \\
\hline
\end{tabular}

6. Wie hoch war der Umsatz Ihres Unternehmens in den vergangenen drei Jahren? (Bitte geben Sie jedes Jahr einzeln an.)

\begin{tabular}{|l|l|}
\hline 1. 2010 & \\
\hline 2. 2011 & \\
\hline 3. 2012 & \\
\hline
\end{tabular}

7. Wie hoch ist der ungefähre Prozentanteil der Herstellermarken in Ihrem Unternehmen in Bezug auf Sortiment und Fertigung?

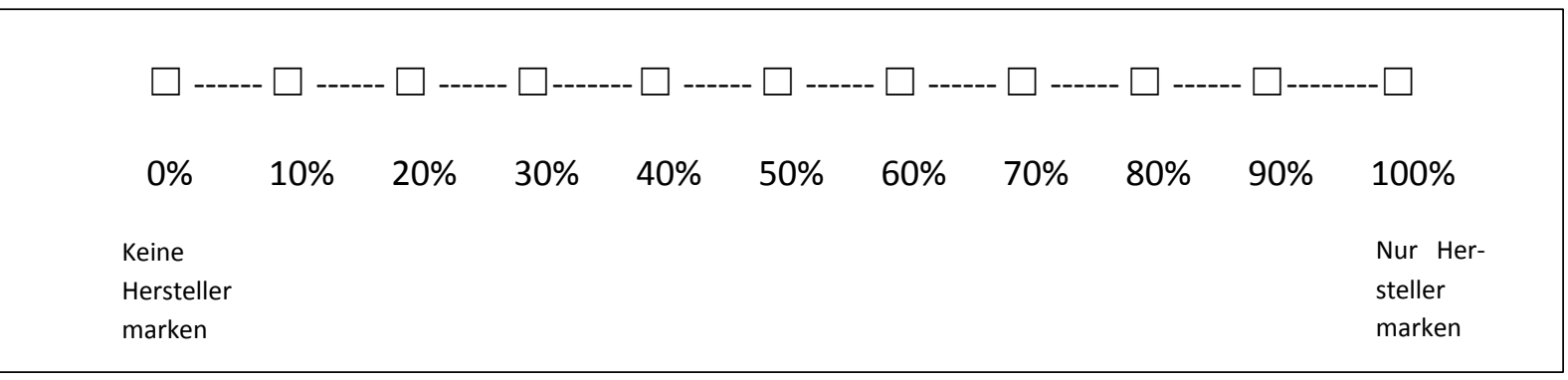

8. Seit wann ist Ihr Unternehmen an ausländischen Märkten tätig?

(Bitte geben Sie das Jahr an.)

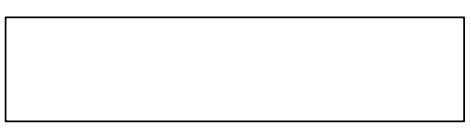

9. Wie hoch ist der Umsatzanteil auf ausländischen Märkten in Prozent von Ihrem Gesamtumsatz?

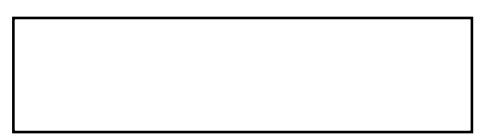

10. Bitte nennen Sie uns Ihre fünf umsatzstärksten Exportprodukte.

\begin{tabular}{|l|l|}
\hline 1. & \\
\hline 2. & \\
\hline
\end{tabular}




\begin{tabular}{|l|l|}
\hline 3. & \\
\hline 4. & \\
\hline 5. & \\
\hline
\end{tabular}

11. Welche Bedeutung haben die folgenden Länder als Absatzmarkt für Ihr Unternehmen?

\begin{tabular}{|l|c|c|c|c|c|c|}
\hline & $\begin{array}{c}1 \\
\text { Bedeutung } \\
\text { shr stark } \\
\text { sinkend }\end{array}$ & $\begin{array}{c}2 \\
\text { Bedeutung } \\
\text { stark sinkend }\end{array}$ & $\begin{array}{c}3 \\
\text { Bedeutung } \\
\text { gleich } \\
\text { bleibend }\end{array}$ & $\begin{array}{c}4 \\
\text { Bedeutung } \\
\text { stark } \\
\text { steigend }\end{array}$ & $\begin{array}{c}5 \\
\text { Bedeutung } \\
\text { sehr stark } \\
\text { steigend }\end{array}$ & $\begin{array}{c}\text { Anteil der Export- } \\
\text { menge in 2015 } \\
\text { voraussichtlich }\end{array}$ \\
\hline $\begin{array}{l}\text { (Westliche) EU- } \\
\text { Staaten (27 Länder) } \\
\text { plus Schweiz und } \\
\text { Skandinavien }\end{array}$ & $\square$ & $\square$ & $\square$ & $\square$ & $\square$ & $\uparrow \square \downarrow \square$ \\
\hline $\begin{array}{l}\text { Mittel- und Ost- } \\
\text { europa (ohne Russ- } \\
\text { land) }\end{array}$ & $\square$ & $\square$ & $\square$ & $\square$ & $\square$ & $\uparrow \square \downarrow \square$ \\
\hline Russland & $\square$ & $\square$ & $\square$ & $\square$ & $\square$ & $\uparrow \square \downarrow \square$ \\
\hline $\begin{array}{l}\text { Nordafrika und Nahe } \\
\text { Osten }\end{array}$ & $\square$ & $\square$ & $\square$ & $\square$ & $\square$ & $\uparrow \square \downarrow \square$ \\
\hline $\begin{array}{l}\text { Afrika- südlich der } \\
\text { Sahara }\end{array}$ & $\square$ & $\square$ & $\square$ & $\square$ & $\square$ & $\uparrow \square \downarrow \square$ \\
\hline Zentralasien & $\square$ & $\square$ & $\square$ & $\square$ & $\square$ & $\uparrow \square \downarrow \square$ \\
\hline China & $\square$ & $\square$ & $\square$ & $\square$ & $\square$ & $\uparrow \square \downarrow \square$ \\
\hline Indien & $\square$ & $\square$ & $\square$ & $\square$ & $\square$ & $\uparrow \square \downarrow \square$ \\
\hline $\begin{array}{l}\text { übriges Ost- und } \\
\text { Südasien (z.B. Indo- } \\
\text { nesien, Malaysia, } \\
\text { Japan, Korea) }\end{array}$ & $\square$ & $\square$ & $\square$ & $\square$ & $\square$ & $\uparrow \square \downarrow \square$ \\
\hline $\begin{array}{l}\text { Australien und Oze- } \\
\text { anien }\end{array}$ & $\square$ & $\square$ & $\square$ & $\square$ & $\square$ & $\uparrow \square \downarrow \square$ \\
\hline Nordamerika & $\square$ & $\square$ & $\square$ & $\square$ & $\square$ & $\uparrow \square \downarrow \square$ \\
\hline $\begin{array}{l}\text { Mittel- und Süd- } \\
\text { amerika }\end{array}$ & $\square$ & $\square$ & $\square$ & $\square$ & $\square$ & $\uparrow \square \downarrow \square$ \\
\hline
\end{tabular}

12. Die Anforderungen der EU an unseren Lebensmittelsektor betrachten wir ...

\begin{tabular}{|c|c|c|c|c|}
\hline $\begin{array}{c}1 \\
\text { als Risiko }\end{array}$ & $\begin{array}{c}2 \\
\text { eher als Risiko }\end{array}$ & $\begin{array}{c}3 \\
\text { weder als Risiko } \\
\text { noch als Chance }\end{array}$ & $\begin{array}{c}4 \\
\text { eher als Chance }\end{array}$ & $\begin{array}{c}5 \\
\text { als Chance }\end{array}$ \\
\hline$\square$ & $\square$ & $\square$ & $\square$ & $\square$ \\
\hline
\end{tabular}


Teil 3: Zertifizierungssysteme

13. Welche Zertifizierungssysteme gibt es in Ihrem Unternehmen?

\begin{tabular}{|c|c|c|c|c|c|}
\hline$\square$ IFS & \multirow{4}{*}{$\begin{array}{l}\square \text { ISO wenn ja, } \\
\text { welches : }\end{array}$} & $\square 22000$ & $\square 9001$ & $\square 13001$ & $\square 15161$ \\
\hline$\square \mathrm{BRC}$ & & & & & \\
\hline$\square \mathrm{PDO} / \mathrm{PGI}$ & & $\square 14001$ & $\square 17025$ & $\square 18001$ & $\square \ldots \ldots$ \\
\hline$\square$ Q\&S & & & & & \\
\hline$\square$ Helal Zertifikat & \multicolumn{5}{|c|}{$\square$ Bio-Zertifikat: (wenn ja welches? Bitte tragen Sie ein) } \\
\hline$\square$ türkischer Kodex & \multirow{2}{*}{\multicolumn{5}{|c|}{$\square$ Sonstiges ; (bitte nennen) }} \\
\hline$\square$ HACCP & & & & & \\
\hline
\end{tabular}

14. Welches sind für Ihr Unternehmen die drei wichtigsten Zertifizierungen, die bei Ihnen vorgenommen wurden? (Bitte tragen Sie Ihre Antworten in die Kästchen ein.)

15. Wann wurden Ihre Hauptzertifizierungssysteme eingeführt? (Bitte geben Sie das Jahr an.)

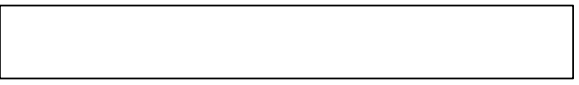

16. a) Wer sind die Kunden für Ihre zertifizierten Produkte? (Bitte die zutreffenden Gruppen ankreuzen.) b) In welche Regionen exportieren Sie Ihre Produkte? (Wählen Sie eine Region aus den Kästchen aus und tragen Sie die Nummer unter "Regionen" ein. Mehrfachnennungen sind möglich.)

\begin{tabular}{|lll|}
\hline 1. Europa & 2. Asien/Pazifik & 3. Eurasien \\
4. Naher Osten/Nordafrika & 5. Subsahara-Afrika & 6. USA \\
\hline
\end{tabular}

\begin{tabular}{|l|c|l|}
\hline \multicolumn{2}{|l|}{ a). Wer sind Ihre Kunden? } & b). Regionen? \\
\hline Naturkosteinzelhändler (Bio-Ladenbetreiber) & $\square$ & \\
\hline Obst- und Gemüsefachhändler mit Ladengeschäften & $\square$ & \\
\hline Sonstige selbstständige Einzelhändler mit Ladengeschäft & $\square$ & \\
\hline Wochenmarkt-Händler & $\square$ & \\
\hline Handelshäuser & $\square$ & \\
\hline Großhändler & $\square$ & \\
\hline Ethnische Ladengeschäfte & $\square$ & \\
\hline Lieferdienste für Lebensmittel & $\square$ & \\
\hline Handelsketten & $\square$ & \\
\hline Gastronomen (Restaurant-, Imbissbetreiber etc.) & $\square$ & \\
\hline Weiterverarbeiter & $\square$ & \\
\hline Supermarktkette & $\square$ & \\
\hline Sonstige (Bitte hier eintragen) .... & & \\
\hline
\end{tabular}


17. Wo liegen die Vorteile des Hauptzertifizierungssystems in Ihrem Unternehmen? (Bitte bewerten Sie die folgenden Statements)

\begin{tabular}{|c|c|c|c|c|c|}
\hline & $\begin{array}{c}1 \\
\text { trifft } \\
\text { überhaupt } \\
\text { nicht zu }\end{array}$ & $\begin{array}{c}2 \\
\text { trifft } \\
\text { weniger } \\
z u\end{array}$ & $\begin{array}{c}3 \\
\text { teils/teils }\end{array}$ & $\begin{array}{c}4 \\
\text { trifft } \\
\text { eher } \\
z u\end{array}$ & $\begin{array}{c}5 \\
\text { trifft voll- } \\
\text { ständig zu }\end{array}$ \\
\hline Strukturierte Darstellung der Forderungen & $\square$ & $\square$ & $\square$ & $\square$ & $\square$ \\
\hline Verbesserte Kundenzufriedenheit & $\square$ & $\square$ & $\square$ & $\square$ & $\square$ \\
\hline $\begin{array}{l}\text { Besseres Verhältnis und bessere Kommunikation mit } \\
\text { Kunden }\end{array}$ & $\square$ & $\square$ & $\square$ & $\square$ & $\square$ \\
\hline Bessere Exportmöglichkeiten & $\square$ & $\square$ & $\square$ & $\square$ & $\square$ \\
\hline $\begin{array}{l}\text { Erhöhung des Markanteils/ bessere Chancen auf } \\
\text { dem Markt }\end{array}$ & $\square$ & $\square$ & $\square$ & $\square$ & $\square$ \\
\hline Steigerung der Effizienz & $\square$ & $\square$ & $\square$ & $\square$ & $\square$ \\
\hline Weniger Arbeitsunfälle & $\square$ & $\square$ & $\square$ & $\square$ & $\square$ \\
\hline Bessere Wettbewerbsfähigkeit & $\square$ & $\square$ & $\square$ & $\square$ & $\square$ \\
\hline $\begin{array}{l}\text { Bessere Kommunikation zwischen Arbeitgeber und } \\
\text { Arbeitnehmern }\end{array}$ & $\square$ & $\square$ & $\square$ & $\square$ & $\square$ \\
\hline Höhere Motivation der Mitarbeiter & $\square$ & $\square$ & $\square$ & $\square$ & $\square$ \\
\hline Stärkung des Vertrauens im Unternehmen & $\square$ & $\square$ & $\square$ & $\square$ & $\square$ \\
\hline Weniger Fehler, reduzierter Materialverlust & $\square$ & $\square$ & $\square$ & $\square$ & $\square$ \\
\hline $\begin{array}{l}\text { Verbesserung des Qualitätsmanagements in den } \\
\text { Unternehmen }\end{array}$ & $\square$ & $\square$ & $\square$ & $\square$ & $\square$ \\
\hline Verbesserung der Produktqualität & $\square$ & $\square$ & $\square$ & $\square$ & $\square$ \\
\hline Steigerung des Unternehmensgewinns & $\square$ & $\square$ & $\square$ & $\square$ & $\square$ \\
\hline Bessere Rückverfolgbarkeit der Produkte & $\square$ & $\square$ & $\square$ & $\square$ & $\square$ \\
\hline $\begin{array}{l}\text { Förderung eines kontinuierlichen Verbesserungs- } \\
\text { prozesses }\end{array}$ & $\square$ & $\square$ & $\square$ & $\square$ & $\square$ \\
\hline $\begin{array}{l}\text { Senkung des finanziellen Aufwandes für die } \\
\text { Qualitätskontrolle }\end{array}$ & $\square$ & $\square$ & $\square$ & $\square$ & $\square$ \\
\hline Sicherere Erfüllung der gesetzlichen Anforderungen & $\square$ & $\square$ & $\square$ & $\square$ & $\square$ \\
\hline Positive Auswirkungen auf die Unternehmensabläufe & $\square$ & $\square$ & $\square$ & $\square$ & $\square$ \\
\hline $\begin{array}{l}\text { Andere.... } \\
\text { (Bitte eintragen) }\end{array}$ & $\square$ & $\square$ & $\square$ & $\square$ & $\square$ \\
\hline
\end{tabular}


18. Wo liegen die Schwachstellen des Standards? (Bitte bewerten Sie die folgenden Statements)

\begin{tabular}{|c|c|c|c|c|c|}
\hline & $\begin{array}{c}1 \\
\text { trifft über- } \\
\text { haupt nicht } \\
z u\end{array}$ & $\begin{array}{c}2 \\
\text { trifft } \\
\text { weniger } \\
z u\end{array}$ & $\begin{array}{c}3 \\
\text { teils/teils }\end{array}$ & $\begin{array}{c}4 \\
\text { trifft } \\
\text { eher zu }\end{array}$ & $\begin{array}{c}5 \\
\text { trifft voll- } \\
\text { ständig zu }\end{array}$ \\
\hline $\begin{array}{l}\text { Es kostet viel Zeit und Geld die Unterlagen der } \\
\text { Zertifizierungssysteme vorzubereiten }\end{array}$ & $\square$ & $\square$ & $\square$ & $\square$ & $\square$ \\
\hline Es mussten neue Mitarbeiter eingestellt werden & $\square$ & $\square$ & $\square$ & $\square$ & $\square$ \\
\hline Schlechte Nachvollziehbarkeit der Anforderungen & $\square$ & $\square$ & $\square$ & $\square$ & $\square$ \\
\hline Großer finanzieller Aufwand & $\square$ & $\square$ & $\square$ & $\square$ & $\square$ \\
\hline Es gibt bei uns Widerstand gegen Neuerungen & $\square$ & $\square$ & $\square$ & $\square$ & $\square$ \\
\hline Schwierige Anwendung in der Praxis & $\square$ & $\square$ & $\square$ & $\square$ & $\square$ \\
\hline Zu hohe Kosten & $\square$ & $\square$ & $\square$ & $\square$ & $\square$ \\
\hline Kosten und Nutzen standen in keinem guten Verhältnis & $\square$ & $\square$ & $\square$ & $\square$ & $\square$ \\
\hline Ungenügende Handlungsorientierung & $\square$ & $\square$ & $\square$ & $\square$ & $\square$ \\
\hline Auditoren können nicht unabhängig entscheiden & $\square$ & $\square$ & $\square$ & $\square$ & $\square$ \\
\hline Die Prüfungsqualität war zu schlecht & $\square$ & $\square$ & $\square$ & $\square$ & $\square$ \\
\hline Die Prüfungsergebnisse waren zu schlecht & $\square$ & $\square$ & $\square$ & $\square$ & $\square$ \\
\hline Die Kriterien sind nicht verständlich & $\square$ & $\square$ & $\square$ & $\square$ & $\square$ \\
\hline Strenge Anforderungen & $\square$ & $\square$ & $\square$ & $\square$ & $\square$ \\
\hline Unzufrieden mit den Informationen des Standardsetzers & $\square$ & $\square$ & $\square$ & $\square$ & $\square$ \\
\hline Andere (bitte eintragen) & $\square$ & $\square$ & $\square$ & $\square$ & $\square$ \\
\hline
\end{tabular}

19. Wurde eine externe Beratung vor Durchführung des Audits in Anspruch genommen?

20. Wurde ein zusätzlicher Mitarbeiter für die Pflege des Standards eingestellt?

\begin{tabular}{|l|l}
$\square$ Ja & $\square$ Nein \\
\hline$\square$ Ja & $\square$ Nein \\
\hline
\end{tabular}

21. Bitte tragen Sie Ihre Antworten in die jeweiligen Kästchen ein

\begin{tabular}{|l|l|}
\hline Wie viele Mitarbeiter sind in Ihrem Unternehmen beschäftigt? & \\
\hline Wie viele davon sind fest angestellt? & \\
\hline Wie viele davon sind als Saisonarbeiter beschäftigt? & \\
\hline
\end{tabular}


22. Wie reagieren die Mitarbeiter auf das Zertifizierungssystem?

\begin{tabular}{|l|c|c|c|c|c|}
\hline & $\begin{array}{c}1 \\
\text { trifft über- } \\
\text { haupt nicht } \\
\text { zu }\end{array}$ & $\begin{array}{c}2 \\
\text { trifft } \\
\text { weniger } \\
\text { zu }\end{array}$ & $\begin{array}{c}3 \\
\text { teils/ } \\
\text { teils }\end{array}$ & $\begin{array}{c}4 \\
\text { trifft } \\
\text { eher zu }\end{array}$ & $\begin{array}{c}5 \\
\text { trifft voll } \\
\text { und ganz } \\
\text { zu }\end{array}$ \\
\hline $\begin{array}{l}\text { Die Mitarbeiter versuchen Verstöße gegen das } \\
\text { Zertifizierungssystem gegenüber Ihrem Vorge- } \\
\text { setzten zu verheimlichen }\end{array}$ & $\square$ & $\square$ & $\square$ & $\square$ & $\square$ \\
\hline $\begin{array}{l}\text { Die Mitarbeiter erachten ihre Vorgesetzten als } \\
\text { kompetent in Bezug auf Fragen, die das Zertifi- } \\
\text { zierungssystem betreffen }\end{array}$ & $\square$ & $\square$ & $\square$ & $\square$ & $\square$ \\
\hline $\begin{array}{l}\text { Die Mitarbeiter haben Angst, ihrem Vorgesetzten } \\
\text { Verstöße gegen das Zertifizierungssystem mitzu- } \\
\text { teilen }\end{array}$ & $\square$ & $\square$ & $\square$ & $\square$ & $\square$ \\
\hline $\begin{array}{l}\text { Die Erteilung eines Zertifikats motiviert die Mit- } \\
\text { arbeiter jeden Tag besser zu werden }\end{array}$ & $\square$ & $\square$ & $\square$ & $\square$ & $\square$ \\
\hline $\begin{array}{l}\text { Die Mitarbeiter sehen ein Zertifikat als Beloh- } \\
\text { nung für ihre Bemühungen, die Qualität } \\
\text { zu verbessern }\end{array}$ & $\square$ & $\square$ & $\square$ & $\square$ & $\square$ \\
\hline $\begin{array}{l}\text { Die Mitarbeiter empfinden die Regeln des Zertifi- } \\
\text { zierungssystems als sinnvoll, da diese Regeln } \\
\text { Unsicherheiten verringern }\end{array}$ & $\square$ & $\square$ & $\square$ & $\square$ & $\square$ \\
\hline $\begin{array}{l}\text { Die Mitarbeiter halten sich an die Regeln des } \\
\text { Zertifizierungssystems }\end{array}$ & $\square$ & $\square$ & $\square$ & $\square$ & $\square$ \\
\hline
\end{tabular}

23. Aus welchen Gründen haben Sie Ihr Zertifizierungssystem ausgewählt? (Wenn Sie mehr als ein Zertifizierungssystem haben, bitte die folgenden Fragen für Ihr Hauptzertifizierungssystem verwenden.)

\begin{tabular}{|l|c|c|c|c|c|}
\hline & $\begin{array}{c}1 \\
\text { trifft über- } \\
\text { haupt nicht } \\
z u\end{array}$ & $\begin{array}{c}2 \\
\text { trifft } \\
\text { weniger } \\
\text { zu }\end{array}$ & $\begin{array}{c}3 \\
\text { teils/ } \\
\text { teils }\end{array}$ & $\begin{array}{c}4 \\
\text { trifft } \\
\text { eher zu }\end{array}$ & $\begin{array}{c}5 \\
\text { trifft voll } \\
\text { und ganz zu }\end{array}$ \\
\hline Kosten-Nutzenrelation & $\square$ & $\square$ & $\square$ & $\square$ & $\square$ \\
\hline Bekanntheitsgrad der Zertifizierungsstelle & $\square$ & $\square$ & $\square$ & $\square$ & $\square$ \\
\hline Örtliche Nähe zum Zertifizierer & $\square$ & $\square$ & $\square$ & $\square$ & $\square$ \\
\hline Auf Empfehlung des Handelsunternehmens & $\square$ & $\square$ & $\square$ & $\square$ & $\square$ \\
\hline Druck von Importländern & $\square$ & $\square$ & $\square$ & $\square$ & $\square$ \\
\hline Druck von Abnehmern & $\square$ & $\square$ & $\square$ & $\square$ & $\square$ \\
\hline Vorgeschlagene Auditzeit der Zertifizierungsstelle & $\square$ & $\square$ & $\square$ & $\square$ & $\square$ \\
\hline Es ist unbürokratischer als andere Systeme & $\square$ & $\square$ & $\square$ & $\square$ & $\square$ \\
\hline $\begin{array}{l}\text { Effektiver (besserer Wirkungsgrad) als andere } \\
\text { Systeme }\end{array}$ & $\square$ & $\square$ & $\square$ & $\square$ & $\square$ \\
\hline
\end{tabular}


24. Hier sind wieder einige Statements zu Ihren Zertifizierungssystemen aufgeführt. Welche dieser Statements unterstützen Sie, welche weniger? (Wenn Sie mehr als ein Zertifizierungssystem haben, bitte die folgenden Fragen für Ihr Hauptzertifizierungssystem verwenden.)

\begin{tabular}{|c|c|c|c|c|c|}
\hline & $\begin{array}{c}1 \\
\text { trifft über- } \\
\text { haupt nicht zu }\end{array}$ & $\begin{array}{c}2 \\
\text { trifft } \\
\text { weniger } \\
\text { zu } \\
\end{array}$ & $\begin{array}{c}3 \\
\text { teils/teils }\end{array}$ & $\begin{array}{c}4 \\
\text { trifft } \\
\text { eher zu }\end{array}$ & $\begin{array}{c}5 \\
\text { trifft voll } \\
\text { und ganz zu }\end{array}$ \\
\hline $\begin{array}{l}\text { Ich bin sehr zufrieden mit meinem } \\
\text { Zertifizierungssystem }\end{array}$ & $\square$ & $\square$ & $\square$ & $\square$ & $\square$ \\
\hline $\begin{array}{l}\text { Zertifizierungssysteme haben in Unter- } \\
\text { nehmen das Lebensmittelsicherheits- } \\
\text { management verbessert }\end{array}$ & $\square$ & $\square$ & $\square$ & $\square$ & $\square$ \\
\hline $\begin{array}{l}\text { Lebensmittel sind mit Zertifizierungs- } \\
\text { systemen sicherer und qualitativ besser } \\
\text { geworden }\end{array}$ & $\square$ & $\square$ & $\square$ & $\square$ & $\square$ \\
\hline $\begin{array}{l}\text { Das Zertifizierungssystem hat die } \\
\text { Beziehungen zu den Kunden verbessert }\end{array}$ & $\square$ & $\square$ & $\square$ & $\square$ & $\square$ \\
\hline $\begin{array}{l}\text { Es ist gleichgültig, welche Zertifizierungsstelle } \\
\text { unser Unternehmen überprüft }\end{array}$ & $\square$ & $\square$ & $\square$ & $\square$ & $\square$ \\
\hline $\begin{array}{l}\text { Verstöße gegen die Kriterien des Zerti- } \\
\text { fizierungssystems fallen nur selten auf }\end{array}$ & $\square$ & $\square$ & $\square$ & $\square$ & $\square$ \\
\hline $\begin{array}{l}\text { Ich kann mein Zertifizierungssystem als } \\
\text { Zertifikat anderen Unternehmen mit gutem } \\
\text { Gewissen weiterempfehlen }\end{array}$ & $\square$ & $\square$ & $\square$ & $\square$ & $\square$ \\
\hline $\begin{array}{l}\text { Die Anforderungen an das Qualitätssystem } \\
\text { durch Zertifizierungssysteme sind genau } \\
\text { richtig so }\end{array}$ & $\square$ & $\square$ & $\square$ & $\square$ & $\square$ \\
\hline $\begin{array}{l}\text { Mit den gegebenen Auditlaufzeiten sind } \\
\text { wir zufrieden }\end{array}$ & $\square$ & $\square$ & $\square$ & $\square$ & $\square$ \\
\hline $\begin{array}{l}\text { Die Umsetzung des Zertifizierungssystems } \\
\text { gibt uns manch nützlichen Hinweis für unser } \\
\text { betriebliches Management }\end{array}$ & $\square$ & $\square$ & $\square$ & $\square$ & $\square$ \\
\hline $\begin{array}{l}\text { Die betrieblichen Kosten für die Umsetzung } \\
\text { des Zertifizierungssystems stehen im } \\
\text { richtigen Verhältnis zum Nutzen }\end{array}$ & $\square$ & $\square$ & $\square$ & $\square$ & $\square$ \\
\hline $\begin{array}{l}\text { Wir hätten auch ohne Vorgabe des Lebens- } \\
\text { mitteleinzelhandels das Zertifizierungssystem } \\
\text { umgesetzt }\end{array}$ & $\square$ & $\square$ & $\square$ & $\square$ & $\square$ \\
\hline $\begin{array}{l}\text { Der zeitliche Aufwand, den wir für den } \\
\text { Zertifizierungsprozess aufwenden müssen, } \\
\text { ist sehr hoch }\end{array}$ & $\square$ & $\square$ & $\square$ & $\square$ & $\square$ \\
\hline $\begin{array}{l}\text { Durch das Zertifizierungssystem werden } \\
\text { unsere Geschäftsablaufe übersichtlicher }\end{array}$ & $\square$ & $\square$ & $\square$ & $\square$ & $\square$ \\
\hline
\end{tabular}


25. Haben Sie schon mal ein Zertifizierungssystem aufgegeben?

$\square$ Ja $\quad \square$ Nein

(Falls Sie oben mit ja geantwortet haben, können Sie uns bitte Ihre Erfahrungen mitteilen, warum Sie zu einem anderen System gewechselt sind? Können Sie uns ebenfalls mitteilen, ob dies im Nachhinein eine gute Entscheidung gewesen ist?)

26. Welche Probleme waren für Ihr Unternehmen besonders schwerwiegend beim Aufbau Ihres Zertifizierungssystems? Können Sie bitte die drei Hauptprobleme nennen?

\begin{tabular}{|c|c|}
\hline 1. & \\
\hline 2. & \\
\hline 3. & \\
\hline
\end{tabular}

27. Sind für die folgenden Bereiche zusätzliche Kosten bei der Einführung des Zertifizierungssystems entstanden?

\begin{tabular}{|l|c|c|c|c|c|}
\hline & $\begin{array}{c}1 \\
\text { trifft über- } \\
\text { haupt nicht } \\
z u\end{array}$ & $\begin{array}{c}2 \\
\text { trifft weni- } \\
\text { ger zu }\end{array}$ & $\begin{array}{c}3 \\
\text { teils/ } \\
\text { teils }\end{array}$ & $\begin{array}{c}4 \\
\text { trifft } \\
\text { eher zu }\end{array}$ & $\begin{array}{c}5 \\
\text { trifft voll } \\
\text { und ganz } \\
z u\end{array}$ \\
\hline Mitarbeiterfortbildung & $\square$ & $\square$ & $\square$ & $\square$ & $\square$ \\
\hline Aufzeichnungspflichten & $\square$ & $\square$ & $\square$ & $\square$ & $\square$ \\
\hline Externe Beratung & $\square$ & $\square$ & $\square$ & $\square$ & $\square$ \\
\hline Neue technische Investitionen & $\square$ & $\square$ & $\square$ & $\square$ & $\square$ \\
\hline Änderungen im Management & $\square$ & $\square$ & $\square$ & $\square$ & $\square$ \\
\hline Infrastruktur und Gebäuderenovierung & $\square$ & $\square$ & $\square$ & $\square$ & $\square$ \\
\hline Laborkosten und -analysen & $\square$ & $\square$ & $\square$ & $\square$ & $\square$ \\
\hline Gerätekalibrierung & $\square$ & $\square$ & $\square$ & $\square$ & $\square$ \\
\hline vorbeugende Instandhaltung & $\square$ & $\square$ & $\square$ & $\square$ & $\square$ \\
\hline Reinigungskräfte & $\square$ & $\square$ & $\square$ & $\square$ & $\square$ \\
\hline andere, und zwar: (Bitte tragen Sie hier ein.) & $\square$ & $\square$ & $\square$ & $\square$ & $\square$ \\
\hline
\end{tabular}


28. Wie wichtig sind die folgenden Aktivitäten für das Gelingen Ihrer Wettbewerbsstrategie?

\begin{tabular}{|l|c|c|c|c|c|}
\hline & $\begin{array}{c}1 \\
\text { gar nicht } \\
\text { wichtig }\end{array}$ & $\begin{array}{c}2 \\
\text { weniger } \\
\text { wichtig }\end{array}$ & $\begin{array}{c}3 \\
\text { teils/teils }\end{array}$ & $\begin{array}{c}4 \\
\text { eher } \\
\text { wichtig }\end{array}$ & $\begin{array}{c}5 \\
\text { sehrwich- } \\
\text { tig }\end{array}$ \\
\hline Effizienz der Arbeitsprozesse sicherstellen & $\square$ & $\square$ & $\square$ & $\square$ \\
\hline Günstig einkaufen (Beschaffung) & $\square$ & $\square$ & $\square$ & $\square$ & $\square$ \\
\hline Innovatives Marketing betreiben & $\square$ & $\square$ & $\square$ & $\square$ & $\square$ \\
\hline Niedrige Preise anbieten & $\square$ & $\square$ & $\square$ & $\square$ & $\square$ \\
\hline Marken- und Firmenreputation kommunizieren & $\square$ & $\square$ & $\square$ & $\square$ & $\square$ \\
\hline $\begin{array}{l}\text { Strebe Kostenführerschaft an, um im } \\
\text { internationalen Wettbewerb zu bestehen }\end{array}$ & $\square$ & $\square$ & $\square$ & $\square$ \\
\hline $\begin{array}{l}\text { Wir setzen im internationalen Wettbewerb auf } \\
\text { Qualitäts- und Innovationsührerschaft }\end{array}$ & $\square$ & $\square$ & $\square$ & $\square$ & $\square$ \\
\hline $\begin{array}{l}\text { Im internationalen Wettbewerb bedienen wir } \\
\text { gezielt Nischen }\end{array}$ & $\square$ & $\square$ & $\square$ & $\square$ \\
\hline $\begin{array}{l}\text { Wir sind meistens vor unseren Mitbewerbern mit } \\
\text { neuen Produkten auf dem Markt }\end{array}$ & $\square$ & $\square$ & $\square$ & $\square$ \\
\hline
\end{tabular}

29. Wie geht Ihr Unternehmen mit dem Thema unternehmerische Verantwortung um?

\begin{tabular}{|c|c|c|c|c|c|}
\hline & $\begin{array}{c}1 \\
\text { lehne voll } \\
\text { und ganz } \\
a b\end{array}$ & $\begin{array}{c}2 \\
\text { lehne } a b\end{array}$ & $\begin{array}{c}3 \\
\text { teils/teils }\end{array}$ & $\begin{array}{c}4 \\
\text { stimme } \\
z u\end{array}$ & $\begin{array}{c}5 \\
\text { stimme } \\
\text { voll und } \\
\text { ganz zu }\end{array}$ \\
\hline $\begin{array}{l}\text { Unternehmerische Verantwortung ist Teil unserer } \\
\text { Marketingstrategie }\end{array}$ & $\square$ & $\square$ & $\square$ & $\square$ & $\square$ \\
\hline $\begin{array}{l}\text { Die Zertifizierung der Wahrnehmung unter- } \\
\text { nehmerischer Verantwortung halte ich für sinnvoll }\end{array}$ & $\square$ & $\square$ & $\square$ & $\square$ & $\square$ \\
\hline Mein Unternehmen wird von der Öffentlichkeit kritisiert & $\square$ & $\square$ & $\square$ & $\square$ & $\square$ \\
\hline $\begin{array}{l}\text { Unsere Lieferanten und Abnehmer schätzen besonders } \\
\text { die faire Zusammenarbeit mit unserem Unternehmen }\end{array}$ & $\square$ & $\square$ & $\square$ & $\square$ & $\square$ \\
\hline $\begin{array}{l}\text { Wir haben sehr starken Druck aufgrund von Eigen- } \\
\text { schaften unserer Produkte (Fett, Zucker, Alkohol) }\end{array}$ & $\square$ & $\square$ & $\square$ & $\square$ & $\square$ \\
\hline $\begin{array}{l}\text { Wir werden für Auswirkungen auf die Umwelt stark } \\
\text { kritisiert (z.B. Emissionen, Abwasser, usw.) }\end{array}$ & $\square$ & $\square$ & $\square$ & $\square$ & $\square$ \\
\hline Für faires Verhalten sind wir allgemein bekannt & $\square$ & $\square$ & $\square$ & $\square$ & $\square$ \\
\hline $\begin{array}{l}\text { Wir legen großen Wert auf die Förderung unserer } \\
\text { Mitarbeiter (z.B. Weiterbildung, Mitarbeiterbeteiligung) }\end{array}$ & $\square$ & $\square$ & $\square$ & $\square$ & $\square$ \\
\hline $\begin{array}{l}\text { Zu Partnern aus dem lokalen/regionalen Umfeld haben } \\
\text { wir besonders enge Geschäftsbeziehungen }\end{array}$ & $\square$ & $\square$ & $\square$ & $\square$ & $\square$ \\
\hline $\begin{array}{l}\text { Unser Unternehmen gilt als ausgesprochen } \\
\text { umweltbewusst }\end{array}$ & $\square$ & $\square$ & $\square$ & $\square$ & $\square$ \\
\hline $\begin{array}{l}\text { Wir haben eine gesellschaftliche Verantwortung, die } \\
\text { uns genauso wichtig ist wie der Gewinn }\end{array}$ & $\square$ & $\square$ & $\square$ & $\square$ & $\square$ \\
\hline Wir arbeiten mit Umweltorganisationen zusammen & $\square$ & $\square$ & $\square$ & $\square$ & $\square$ \\
\hline
\end{tabular}


30. In welcher Abteilung sind Sie überwiegend tätig im Betrieb?

\begin{tabular}{|l|}
\hline$\square$ Geschäftsinhaber \\
\hline$\square$ Geschäftsleiter \\
\hline$\square$ im Bereich Einkauf \& Verkauf \\
\hline$\square$ im Bereich Export- Import \\
\hline$\square$ im Bereich Qualitätsmanagement \\
\hline$\square$ im Bereich Marketing \\
\hline$\square$ Sonstiges \\
\hline
\end{tabular}

31. Was ist Ihr höchster Ausbildungsabschluss?

\begin{tabular}{|l|l|}
\hline$\square$ Volks- bzw. Hauptschule & $\square$ Meister, Techniker, Fachhochschulabschluss \\
\hline$\square$ Realschule o. ä. & $\square$ Bachelorabschluss \\
\hline$\square$ (Fach-)Hochschulreife & $\square$ Masterabschluss \\
\hline$\square$ Hochschulabschluss & $\square$ Promotion \\
\hline$\square$ ohne Abschluss & $\square$ Sonstiges \\
\hline
\end{tabular}

Ihr Geschlecht: $\square$ männlich $\quad \square$ weiblich

Ihr Alter:

Uhrzeit bei Beendigung des Fragebogens: __ : U Uhr

\section{Vielen Dank für Ihre Mitarbeit!}




\section{Araştırma konusu: Türk tarım ve gıda sektöründe sertifika sistemleri}

Sayın yetkili kişi;

Tuba Pekkırbızlı doktora çalışmalarını Georg-August Üniversitesi' nde (Göttingen) sürdürmektedir. Doktora çalışmalarının konusu ise, Türk tarım ve gıda sanayisinde kalite güvence sistemleri olup bu sebepden dolayı Türk tarım ve gıda firmalarında ampirik bir araştırma yürütmektedir. Çalışmanın hedefi; Türk tarım ve gıda sektöründe Belgelendirme sistemlerini yei ve öenmini daha iyi anlamak, bu konudaki zorlukları ve eksiklikleri ortaya çıkarabilmektir.

Uygulamalaya geçirilmiş bilgiler, anlam taşıyacak bilimsel çalışmalar için çok önemli ve gereklidir. Bu bilimsel projeyi destekler ve ekde sunulmuş olan anketi mümkün olduğunca eksiksiz cevap verirseniz, size çok minnettar olur, teşekkürü bir boç bilirim.

Vereceğiniz her bir yanıt bu projenin başarısına katkıda bulunacaktır. Lütfen anketi eksiksiz doldurmaya çalışın. Eğer herhangi bir soruya cevap vermek istemiyorsanız yada cevap veremiyorsanız, lütfen bir sonraki soruya geçip anketi doldurmaya devam edin. Olası sorularınız, yorumlarınız için herzaman Tuba Pekkırbızlı ile görüşebilirsiniz.

Vermiş olduğunuz tüm bilgiler ve veriler sadece bu doktora çalışması için kullanılacaktır ve kesinlikle çok gizli tutulacaktır.

Desteğiniz ve ayırdığınız zaman için çok teşekkür ederim.

Saygılarımla

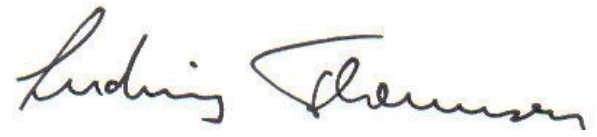

Prof. Dr. Ludwig Theuvsen
Tûba Pekkırbızıı Email: tpekkirbizli@yahoo.de Tel: 05352766801 


\begin{tabular}{|l|l|}
\hline Anketin yapıldığı tarih: & $\ldots / \ldots / 2013$ \\
\hline Ankete başlama saati: & Saat _ _ \\
\hline
\end{tabular}

\section{Bölüm 1: Genel sorular}

1.

\begin{tabular}{|l|l|l|}
\hline Şirketiniz tarım ve gıda ürünlerini ihracat ediyor mu? & Evet $\square$ & Hayır $\square$ \\
\hline
\end{tabular}

2. Şirketinizin hukuksal yapısı nedir?

\begin{tabular}{|l|l|}
\hline$\square$ Limited şirket & $\square$ Kollektif şirket \\
\hline$\square$ Anonim şirket & $\square$ Diğer, (lütfen aşağıdaki boşluğa yazınız) \\
\hline$\square$ Komandit şirket & \\
\hline
\end{tabular}

3. Şirketinizin merkezi hangi bölgede bulunmaktadır?

(Ĕger şirket birden fazla farklı bölgelerde bulunuyorsa, birden fazla cevap mümkün)

\begin{tabular}{|l|l|}
\hline$\square$ iç Anadolu Bölgesi & $\square$ Doğu Anadolu Bölgesi \\
\hline$\square$ Akdeniz Bölgesi & $\square$ Karadeniz Bölgesi \\
\hline$\square$ Ege Bölgesi & $\square$ Güneydoğu Anadolu Bölgesi \\
\hline$\square$ Marmara Bölgesi & \multicolumn{1}{|c}{} \\
\cline { 1 - 2 } &
\end{tabular}

4. Şirketiniz de işlem gören gıda ürünlerini lütfen aşağıda işaretleyiniz. (birden fazla cevap mümkün)

\begin{tabular}{|l|l|l|}
\hline$\square$ Şekerli ve çikolatalı mamüller & $\square$ işlenmiş meyve- sebze & $\square$ Taze meyve ve sebze \\
\hline$\square$ Kek ve makarna & $\square$ Yağlar & $\square$ Et ve et ürünleri \\
\hline$\square$ Bakliyat ve hububat & $\square$ Alkollü içecekler & $\square$ Çay ve bitkisel çaylar \\
\hline$\square$ Un ve unlu mamüller & $\square$ Alkolsüz içecekler & $\square$ işlenmiş süt \\
\hline$\square$ Kurutulmuş meyve & $\square$ Nişasta ve mamülleri & $\square$ Domates salçası ve domates ürünleri \\
\hline$\square$ Kurutulmuş sebze & $\square$ Yağlı tohumlar & $\square$ Fındık ve mamülleri \\
\hline$\square$ Yumurta & $\square$ Baharatlar & $\square$ Kanatlı et \\
\hline$\square$ Su ürünleri & $\square$ Katkı maddeler & $\square$ Kahve \\
\hline$\square$ Hayvan yemi üretimi & $\square$ Diğer,/ütfen belirtiniz: $\rightarrow$ & \\
\hline
\end{tabular}

\begin{tabular}{|l|l|l|}
\hline 5̧irketiniz bir aile şirketimi ? & Evet $\square$ & Hayır $\square$ \\
\hline
\end{tabular} 
6. Son üç yıl içindeki şirket cironuz nedir? (Lütfen her yıl için ayrı ayrı belirtiniz.)

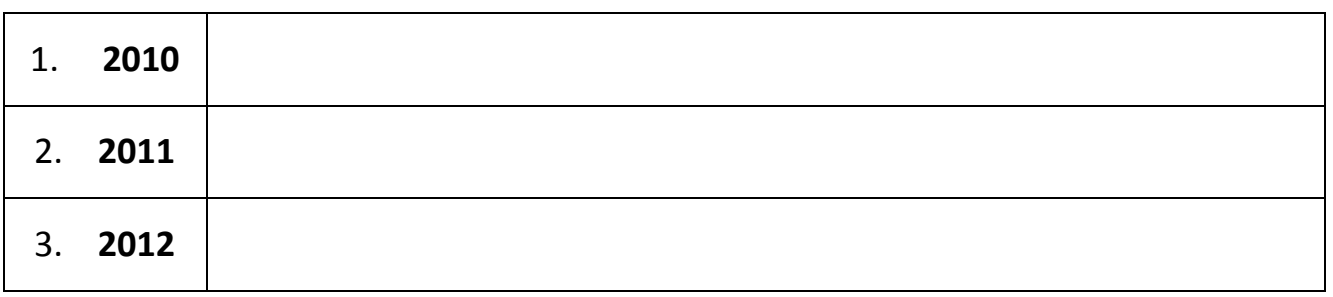

7. Şirketinizdeki ticari marka olmayan ürün çeşitlerinin ve işlenmiş gıda ürünlerinin yaklaşık yüzde oranı nedir? (Lütfen aşağıdaki kutudan işaretleyiniz)

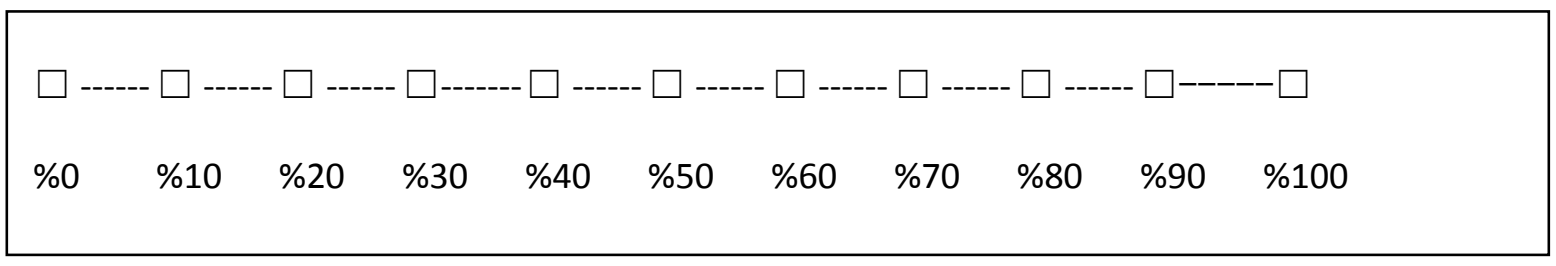

8. Şirketiniz dış pazar ticaretine nezaman başladı ? (Sadece yıl olarak belirtiniz)

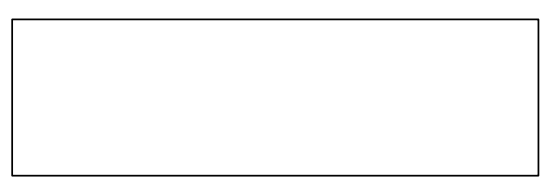

9. Şirketinizin toplam yıllık cironuzun yüzde kaçını dış ticaretden elde ediyorsunuz? (lütfen aşağıdaki kutuya yazınız)

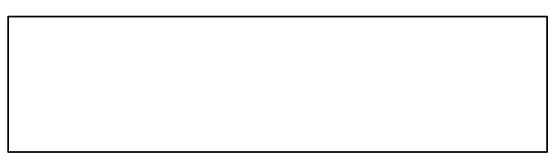

10. Lütfen aşağıdaki kutulara en çok satış yaptığınız beş ihraç ürünün isimlerini belirtiniz.

\begin{tabular}{|l|l|}
\hline 1. & \\
\hline 2. & \\
\hline 3. & \\
\hline 4. & \\
\hline 5. & \\
\hline
\end{tabular}


11. Aşağıda belirtilen ülkelerin/ bölgelerin şirketinizin satış piyasası açısından önemi nedir?(Tablonun son iki sütunu hakkında açıklama):

a) 2012 yılındaki ihracat hacmindeki payı b) 2015 yılında olacak ihracat hacmindeki tahmini payı

$\square \uparrow=$ ihracat hacmindeki payının artmasını simgeliyor

$\square \downarrow=$ ihracat hacmindeki payının düşmesini simgeliyor.

\begin{tabular}{|c|c|c|c|c|c|c|c|}
\hline & $\begin{array}{c}1 \\
\text { önemi } \\
\text { çok } \\
\text { fazla } \\
\text { düşüşte }\end{array}$ & 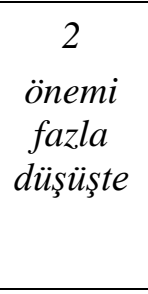 & $\begin{array}{c}3 \\
\text { önemi ne } \\
\text { düşüyor } \\
\text { nede } \\
\text { artıyor }\end{array}$ & $\begin{array}{c}4 \\
\text { önemi } \\
\text { fazla } \\
\text { artmakta }\end{array}$ & $\begin{array}{c}5 \\
\text { önemi } \\
\text { çok } \\
\text { fazla } \\
\text { artmak } \\
\text { ta } \\
\end{array}$ & $\begin{array}{c}\text { a) } \\
2012\end{array}$ & $\begin{array}{c}\text { b) } \\
2015 \\
\text { tahmini }\end{array}$ \\
\hline $\begin{array}{l}\text { Bat1 Avrupa Birliği } \\
\text { ülkeleri(27 ülke) } \\
\text { İsviçre ve iskandinavya } \\
\text { dahil }\end{array}$ & $\square$ & $\square$ & $\square$ & $\square$ & $\square$ & $\uparrow \square \downarrow \square$ & $\uparrow \square \downarrow \square$ \\
\hline $\begin{array}{l}\text { Orta ve doğu Avrupa } \\
\text { (Rusya hariç) }\end{array}$ & $\square$ & $\square$ & $\square$ & $\square$ & $\square$ & $\uparrow \square \downarrow \square$ & $\uparrow \square \downarrow \square$ \\
\hline Rusya & $\square$ & $\square$ & $\square$ & $\square$ & $\square$ & $\uparrow \square \downarrow \square$ & $\uparrow \square \downarrow \square$ \\
\hline Orta Asya & $\square$ & $\square$ & $\square$ & $\square$ & $\square$ & $\uparrow \square \downarrow \square$ & $\uparrow \square \downarrow \square$ \\
\hline Çin Halk Cumhuriyeti & $\square$ & $\square$ & $\square$ & $\square$ & $\square$ & $\uparrow \square \downarrow \square$ & $\uparrow \square \downarrow \square$ \\
\hline Hindistan & $\square$ & $\square$ & $\square$ & $\square$ & $\square$ & $\uparrow \square \downarrow \square$ & $\uparrow \square \downarrow \square$ \\
\hline $\begin{array}{l}\text { Güneydoğu Asyanın } \\
\text { geri kalanı (Endonezya, } \\
\text { Malezya gibi..) }\end{array}$ & $\square$ & $\square$ & $\square$ & $\square$ & $\square$ & $\uparrow \square \downarrow \square$ & $\uparrow \square \downarrow \square$ \\
\hline $\begin{array}{l}\text { Avustralya ve } \\
\text { Okyanusya }\end{array}$ & $\square$ & $\square$ & $\square$ & $\square$ & $\square$ & $\uparrow \square \downarrow \square$ & $\uparrow \square \downarrow \square$ \\
\hline $\begin{array}{l}\text { Afrika ülkeleri ve Orta } \\
\text { Doğu }\end{array}$ & $\square$ & $\square$ & $\square$ & $\square$ & $\square$ & $\uparrow \square \downarrow \square$ & $\uparrow \square \downarrow \square$ \\
\hline Kuzey Amerika & $\square$ & $\square$ & $\square$ & $\square$ & $\square$ & $\uparrow \square \downarrow \square$ & $\uparrow \square \downarrow \square$ \\
\hline $\begin{array}{l}\text { Orta ve Güney } \\
\text { Amerika }\end{array}$ & $\square$ & $\square$ & $\square$ & $\square$ & $\square$ & $\uparrow \square \downarrow \square$ & $\uparrow \square \downarrow \square$ \\
\hline $\begin{array}{l}\text { Birleşik Arap } \\
\text { Emirlikleri }\end{array}$ & $\square$ & $\square$ & $\square$ & $\square$ & $\square$ & $\uparrow \square \downarrow \square$ & $\uparrow \square \downarrow \square$ \\
\hline Suudi Arabistan & $\square$ & $\square$ & $\square$ & $\square$ & $\square$ & $\uparrow \square \downarrow \square$ & $\uparrow \square \downarrow \square$ \\
\hline $\begin{array}{l}\text { Diğer..(Lütfen } \\
\text { belirtiniz) }\end{array}$ & $\square$ & $\square$ & $\square$ & $\square$ & $\square$ & $\uparrow \square \downarrow \square$ & $\uparrow \square \downarrow \square$ \\
\hline
\end{tabular}

12. Avrupa Birliğinin Türk tarım ve gıda sektörüne yönelik taleplerini nasıl değerlendiriyorsunuz?

\begin{tabular}{|c|c|c|c|c|}
\hline $\begin{array}{c}1 \\
\text { çok riskli }\end{array}$ & $\begin{array}{c}2 \\
\text { riskli }\end{array}$ & $\begin{array}{c}3 \\
\text { ne risk ne de fırsat }\end{array}$ & $\begin{array}{c}4 \\
\text { fırsat }\end{array}$ & $\begin{array}{c}5 \\
\text { büyük bir fırsat }\end{array}$ \\
\hline$\square$ & $\square$ & $\square$ & $\square$ & $\square$ \\
\hline
\end{tabular}




\section{Bölüm 3: Sertifikalandırma Sistemleri}

13. Şirketinizde aşağıdaki Sertifika Sistemlerinden hangisi/ -leri uygulanmaktadır? (birden fazla cevap mümkün)

\begin{tabular}{|c|c|c|c|c|c|}
\hline$\square$ IFS & \multirow{4}{*}{$\begin{array}{l}\square \text { ISO eğer cevabınız } \\
\text { evetse, Hangisi? } \rightarrow\end{array}$} & $\square 22000$ & $\square 9001$ & $\square 13001$ & $\square 15161$ \\
\hline$\square$ BRC & & $\square 14001$ & $\square 17025$ & $\square 18001$ & $\square \ldots \ldots$ \\
\hline$\square$ PDO/PGI & & & & & \\
\hline$\square Q \& S$ & & & & & \\
\hline$\square$ Helâl Sertifikası & \multicolumn{5}{|c|}{$\square$ BiO Sertifikası ( eğer cevabınız evetse, lütfen hangisi olduğunu belirtiniz.) $\rightarrow$} \\
\hline$\square$ Türk Gıda Kodeksi & \multirow{2}{*}{\multicolumn{5}{|c|}{$\square$ Diğer; (lütfen buraya yazınız) $\rightarrow$}} \\
\hline$\square$ HACCP & & & & & \\
\hline
\end{tabular}

14. Şirketinizde uygulanan Sertifika Sistemlerinden hangisi sizin için (Şirketiniz için) en önemli olanıdır?(lütfen aşağıdki kutuya yazınız)

15. Anamerkez olan (merkezi) sertika sistemi şirketinizde ne zaman uygulanmaya başlanıldı? (Sadece yıl olarak belirtiniz)

16. a). Sertifikalı ürünlerinizin müşterileri kimlerdir? (Lütfen size uygun alan/ alanları işaretleyiniz) b). Hangi bölge/ bölgelere ürünlerinizi ihraç ediyorsunuz? (Aşağıdaki kutudan size uygun olan bölge/- leri "b). Bölge?" başlığının altına sadece rakamları ile yazınız.Birden fazla cevap(bölge)

mümkündür. ** Aşagıdaki bölgelerin hangi ülkeleri kapsadığı konusunda tereddüt yaşıyorsanız; anketin son bölümünde "Ekler" kısmında ülkelerin bölgelere göre dağıımını içeren bilgiyi bulabilirsiniz.

\begin{tabular}{|lll|}
\hline 1. Avrupa & 2. Asya- Pasifik & 3. Avrasya \\
4. Ortadoğu-Kuzey Afrika & 5. Sahra Altı Afrika & 6. Amerika \\
\hline
\end{tabular}

\begin{tabular}{|l|c|l|}
\hline a). Müşterileniz kimlerdir? & $\square$ & \\
\hline Organik- Doğal gıda perakendecileri & $\square$ & \\
\hline Meyve sebze perakendicileri & $\square$ & \\
\hline Kendi işletmesi olan küçük esnaflar & $\square$ & \\
\hline Haftalık Pazar esnafı & $\square$ & \\
\hline Ticari şirketler & $\square$ & \\
\hline Toptancılar & $\square$ & \\
\hline Etnik gııda mağazaları & $\square$ & \\
\hline Gıda taşıma- teslim servisleri & $\square$ & \\
\hline Perakende mağazalar zinciri & $\square$ & \\
\hline Lokanta, restoranlara ve büfelere & $\square$ & \\
\hline Süpermarketler zinciri & $\square$ & \\
\hline Gıda işletmecileri & $\square$ & \\
\hline Diğer; (lütfen buraya yazınız) & $\square$ & \\
\hline
\end{tabular}


17. Şirketinizdeki anamerkez Sertifika Sisteminin faydaları nelerdir? (Aşağıdaki ifadeleri siz nasıl değerlendiyorsunuz?) (Lütfen her ifadeyi değerlendirin ve her ifade için tek bir cevap verin)

\begin{tabular}{|c|c|c|c|c|c|}
\hline & $\begin{array}{c}1 \\
\text { hiç doğru } \\
\text { değil }\end{array}$ & $\begin{array}{c}2 \\
\text { doğru } \\
\text { değil }\end{array}$ & $\begin{array}{c}3 \\
\text { ne doğru } \\
\text { ne yanlış }\end{array}$ & $\begin{array}{c}4 \\
\text { doğru }\end{array}$ & $\begin{array}{c}5 \\
\text { çok } \\
\text { doğru }\end{array}$ \\
\hline $\begin{array}{l}\text { Sertifika sistemi tarafından belirlenen talepler } \\
\text { anlaşıır bir biçimdedir }\end{array}$ & $\square$ & $\square$ & $\square$ & $\square$ & $\square$ \\
\hline Müşteri memnuniyetinde artış elde edilmiştir & $\square$ & $\square$ & $\square$ & $\square$ & $\square$ \\
\hline $\begin{array}{l}\text { Müşteri ile daha iyi ilişki ve iletişim } \\
\text { sağlanmıştır }\end{array}$ & $\square$ & $\square$ & $\square$ & $\square$ & $\square$ \\
\hline Daha iyi ihracat olasılıkları elde edilmiştir & $\square$ & $\square$ & $\square$ & $\square$ & $\square$ \\
\hline $\begin{array}{l}\text { Pazar payı artışı/ piyasa imkanlarının artışı } \\
\text { sağlanmıştır }\end{array}$ & $\square$ & $\square$ & $\square$ & $\square$ & $\square$ \\
\hline Piyasa etkinliğinde artış sağlanmıştır & $\square$ & $\square$ & $\square$ & $\square$ & $\square$ \\
\hline İş kazalarında azalma olmuştur & $\square$ & $\square$ & $\square$ & $\square$ & $\square$ \\
\hline Şirketin rekabet gücü artmıştır & $\square$ & $\square$ & $\square$ & $\square$ & $\square$ \\
\hline $\begin{array}{l}\text { İşveren ve çalışanlar arasındaki iletişimde } \\
\text { iyileşme ve gelişmeler sağlanmıştır. }\end{array}$ & $\square$ & $\square$ & $\square$ & $\square$ & $\square$ \\
\hline $\begin{array}{l}\text { Personelin çalışma motivasyonunda } \\
\text { iyileşmeler sağlanmıştır }\end{array}$ & $\square$ & $\square$ & $\square$ & $\square$ & $\square$ \\
\hline Şirkete duyulan güvende artış sağlanmıştır & $\square$ & $\square$ & $\square$ & $\square$ & $\square$ \\
\hline $\begin{array}{l}\text { Çalışma alanlarında hata yapma sıklığında ve } \\
\text { malzeme kayıplarında azalmalar sağlanmıştır }\end{array}$ & $\square$ & $\square$ & $\square$ & $\square$ & $\square$ \\
\hline $\begin{array}{l}\text { Şirketde kalite yönetiminde iyileşme ve } \\
\text { gelişmeler sağlanmıştır }\end{array}$ & $\square$ & $\square$ & $\square$ & $\square$ & $\square$ \\
\hline $\begin{array}{l}\text { Şirket ürünlerindeki kalitede iyileşme } \\
\text { sağlanmıştır }\end{array}$ & $\square$ & $\square$ & $\square$ & $\square$ & $\square$ \\
\hline Şirket kazancında yükselmeler sağlanmıştır & $\square$ & $\square$ & $\square$ & $\square$ & $\square$ \\
\hline $\begin{array}{l}\text { Şirket ürünlerinde ürün takip etme } \\
\text { sisteminde/ izlenebilirlikde iyileşme } \\
\text { sağlanmıştır }\end{array}$ & $\square$ & $\square$ & $\square$ & $\square$ & $\square$ \\
\hline $\begin{array}{l}\text { Şirket içi "kendini sürekli iyileştirme" } \\
\text { anlayışına teşvik sağlanmıştır }\end{array}$ & $\square$ & $\square$ & $\square$ & $\square$ & $\square$ \\
\hline $\begin{array}{l}\text { Kalite Kontrol için yapılan harcamalarda } \\
\text { azalma sağlanmıştır }\end{array}$ & $\square$ & $\square$ & $\square$ & $\square$ & $\square$ \\
\hline $\begin{array}{l}\text { Kanuni yükümlülüklerin yerine getirmede } \\
\text { güven ve iyileşme sağlanmıştır }\end{array}$ & $\square$ & $\square$ & $\square$ & $\square$ & $\square$ \\
\hline $\begin{array}{l}\text { Şirketin genel işleyişinde olumlu etkiler elde } \\
\text { edilmiştir }\end{array}$ & $\square$ & $\square$ & $\square$ & $\square$ & $\square$ \\
\hline
\end{tabular}


18. Standardizasyonun sizce eksiklikleri veya eleştiri alabilecek noktaları nelerdir? (Aşağıdaki ifadeleri siz nasıl değerlendiyorsunuz?) (Lütfen her ifadeyi değerlendirin ve her ifade için tek bir cevap verin)

\begin{tabular}{|l|c|c|c|c|c|}
\hline & $\begin{array}{c}1 \\
\text { hiç doğru } \\
\text { değil }\end{array}$ & $\begin{array}{c}2 \\
\text { doğru } \\
\text { değil }\end{array}$ & $\begin{array}{c}3 \\
\text { ne doğru } \\
\text { ne yanlış }\end{array}$ & $\begin{array}{c}4 \\
\text { doğru }\end{array}$ & $\begin{array}{c}5 \\
\text { çok } \\
\text { doğru }\end{array}$ \\
\hline $\begin{array}{l}\text { Sertifika sistemleri için gereken belgeleri } \\
\text { hazırlamak çok pahalı ve çok zaman alıyor }\end{array}$ & $\square$ & $\square$ & $\square$ & $\square$ & $\square$ \\
\hline Yeni personel alımı zorunluluğu ortaya çıkabiliyor & $\square$ & $\square$ & $\square$ & $\square$ & $\square$ \\
\hline Taleplerin çok zor kavranması, anlaşılır olmaması & $\square$ & $\square$ & $\square$ & $\square$ & $\square$ \\
\hline Büyük maddi külfet gerektiriyor & $\square$ & $\square$ & $\square$ & $\square$ & $\square$ \\
\hline Şirketimizde yeniliklere karşı direniş mevcut & $\square$ & $\square$ & $\square$ & $\square$ & $\square$ \\
\hline Günlük uygulamalarda rastlanan zorluklar & $\square$ & $\square$ & $\square$ & $\square$ & $\square$ \\
\hline Maliyeti çok yüksek & $\square$ & $\square$ & $\square$ & $\square$ & $\square$ \\
\hline Maliyet- Fayda- Oranı dengede değil & $\square$ & $\square$ & $\square$ & $\square$ & $\square$ \\
\hline Ticari hareket alanı yeterli değil & $\square$ & $\square$ & $\square$ & $\square$ & $\square$ \\
\hline Denetleyiciler kararlarında bağımsız olamıyorlar & $\square$ & $\square$ & $\square$ & $\square$ & $\square$ \\
\hline Denetlemenin kalitesi çok kötüydü & $\square$ & $\square$ & $\square$ & $\square$ & $\square$ \\
\hline Denetlemenin sonuçları hiç tatmin edici değildi & $\square$ & $\square$ & $\square$ & $\square$ & $\square$ \\
\hline $\begin{array}{l}\text { İstenilen , yapılmak zorunda olunan } \\
\text { kriterleri anlamak çok zor }\end{array}$ & $\square$ & $\square$ & $\square$ & $\square$ & $\square$ \\
\hline Çok sıkı ve sert talepleri var & $\square$ & $\square$ & $\square$ & $\square$ & $\square$ \\
\hline $\begin{array}{l}\text { Standart belirleyiciden gelen bilgilerden } \\
\text { memnun degiliz }\end{array}$ & $\square$ & $\square$ & $\square$ & $\square$ & $\square$ \\
\hline Diğer, (lütfen buraya yazıız) & $\square$ & $\square$ & $\square$ & $\square$ & $\square$ \\
\hline
\end{tabular}

19. Şirketiniz denetimden önce herhangi bir danışman (dışardan) servisinden yararlandımı?

20. Şirketiniz standartlardan sorumlu olan yeni personel alımı yaptımı?

21. Aşağıdaki soruların cevabını lütfen yandaki boşluğa yazınız.

Şirketinizde toplamda ne kadar kişi çalışıyor?

Bu kişilerden kaç tanesi kadrolu olarak çalışıyor?

Bu kişilerden kaçı mevsimlik işci olarak çalışıyor? 
22. Sertifika Sisteminin şirket elemanları üzerindeki etkisi nasıl oldu? (Lütfen her ifadeyi değerlendirin ve her ifade için tek bir cevap verin)

\begin{tabular}{|l|c|c|c|c|c|}
\hline & $\begin{array}{c}1 \\
\text { hiç doğru } \\
\text { değil }\end{array}$ & $\begin{array}{c}2 \\
\text { doğru } \\
\text { değil }\end{array}$ & $\begin{array}{c}3 \\
\text { ne doğru } \\
\text { ne yanlış }\end{array}$ & $\begin{array}{c}4 \\
\text { doğru }\end{array}$ & $\begin{array}{c}5 \\
\text { çok } \\
\text { doğru }\end{array}$ \\
\hline $\begin{array}{l}\text { Şirket çalışanları sertifika sisteminin kurallarını ihlal } \\
\text { ettikleri zaman bunu amirlerinden saklmaya çalışıyorlar }\end{array}$ & $\square$ & $\square$ & $\square$ & $\square$ & $\square$ \\
\hline $\begin{array}{l}\text { Şirket çalışanları sertifika sistemine dair bütün sorularda } \\
\text { ammirlerini yetkili kişi olarak görüyorlar }\end{array}$ & $\square$ & $\square$ & $\square$ & $\square$ & $\square$ \\
\hline $\begin{array}{l}\text { Şirket elemanları sertifika sistemi ihlallerini amirleri ile } \\
\text { konuşmaktan korkuyorlar }\end{array}$ & $\square$ & $\square$ & $\square$ & $\square$ & $\square$ \\
\hline $\begin{array}{l}\text { Şirketimizin sertifikaya sahip olması, şirket elemanlarını } \\
\text { hergün daha iyiye ulaşmak için motive ediyor }\end{array}$ & $\square$ & $\square$ & $\square$ & $\square$ & $\square$ \\
\hline $\begin{array}{l}\text { Şirket elemanları sertifikayı kaliteyi yükseltme } \\
\text { çabalarına karşılık bir ödül olarak görüyorlar }\end{array}$ & $\square$ & $\square$ & $\square$ & $\square$ & $\square$ \\
\hline $\begin{array}{l}\text { Şirket çalışanları, sertifika sistemi kurallarının } \\
\text { belirsizlikleri giderdiğini düşündükleri için bu kuralları } \\
\text { anlamlı, mantıklı ve uygun görüyorlar }\end{array}$ & $\square$ & $\square$ & $\square$ & $\square$ & $\square$ \\
\hline $\begin{array}{l}\text { Şirket çalışanları genel olarak sertifika sisteminin } \\
\text { kurallarına uyuyorlar }\end{array}$ & $\square$ & $\square$ & $\square$ & $\square$ & $\square$ \\
\hline
\end{tabular}

23. Sertifika sisteminize hangi nedenlerden dolayı karar verdiniz? ( Eger şirketiniz de birden fazla sertifika sistemini bulunduyorsanız, lütfen aşağıdaki ifadeleri anamerkez sertifika sisteminizi göz önünde tutarak cevaplandırınız) (Lütfen her ifadeyi değerlendirin ve her ifade için tek bir cevap verin)

\begin{tabular}{|l|c|c|c|c|c|}
\hline & $\begin{array}{c}1 \\
\text { hiç doğru } \\
\text { değil }\end{array}$ & $\begin{array}{c}2 \\
\text { doğru } \\
\text { değil }\end{array}$ & $\begin{array}{c}3 \\
\text { ne doğru } \\
\text { ne yanlış }\end{array}$ & $\begin{array}{c}4 \\
\text { doğru }\end{array}$ & $\begin{array}{c}5 \\
\text { çok } \\
\text { doğru }\end{array}$ \\
\hline Maliyet- Fayda Oranına göre & $\square$ & $\square$ & $\square$ & $\square$ & $\square$ \\
\hline Denetleyicinin tanınmışlık derecesine göre & $\square$ & $\square$ & $\square$ & $\square$ & $\square$ \\
\hline $\begin{array}{l}\text { Sertifikayı veren denetleyicinin bölgesel yakınlığına } \\
\text { göre }\end{array}$ & $\square$ & $\square$ & $\square$ & $\square$ & $\square$ \\
\hline Diğer ticari şirketlerin tavsiyesi üzerine & $\square$ & $\square$ & $\square$ & $\square$ & $\square$ \\
\hline Ithalatçı ülkerin yoğun isteği üzerine & $\square$ & $\square$ & $\square$ & $\square$ & $\square$ \\
\hline Müşterilerin baskısından dolayı & $\square$ & $\square$ & $\square$ & $\square$ & $\square$ \\
\hline $\begin{array}{l}\text { Diğer sistemlere göre daha az bürokratik olduğu } \\
\text { için }\end{array}$ & $\square$ & $\square$ & $\square$ & $\square$ & $\square$ \\
\hline İyi etkinlik (etkili) derecesine sahip olmasına göre & $\square$ & $\square$ & $\square$ & $\square$ & $\square$ \\
\hline Diğer, (lütfen buraya yazınız) & $\square$ & $\square$ & $\square$ & $\square$ & $\square$ \\
\hline
\end{tabular}


24. Aşağıda sertika sisteminiz ile ilgili ifadeler verilmiştir.

Bunlardan hangilerine katılıyor hangilerine katılmıyorsunuz?

(Lütfen her ifadeyi değerlendirin ve her ifade için tek bir cevap verin)(Eger şirketiniz de birden fazla sertifika sistemini bulunduyorsanız, lütfen aşağıdaki ifadeleri anamerkez sertifika sisteminizi göz önünde tutarak cevaplandırınız)

\begin{tabular}{|l|c|c|c|c|c|}
\hline & $\begin{array}{c}1 \\
\text { hiç doğru } \\
\text { değil }\end{array}$ & $\begin{array}{c}2 \\
\text { doğru } \\
\text { değil }\end{array}$ & $\begin{array}{c}3 \\
\text { ne doğru } \\
\text { ne yanlış }\end{array}$ & $\begin{array}{c}4 \\
\text { doğru }\end{array}$ & $\begin{array}{c}\text { çok } \\
\text { doğru }\end{array}$ \\
\hline Sertifika sisteminden çok memnunum & $\square$ & $\square$ & $\square$ & $\square$ & $\square$ \\
\hline $\begin{array}{l}\text { Sertifika sistemi sayesinde, şirketdeki gıda } \\
\text { güvenirliği yönetiminde iyileşmeler elde edilmiştir }\end{array}$ & $\square$ & $\square$ & $\square$ & $\square$ & $\square$ \\
\hline $\begin{array}{l}\text { Gıda maddeleri, sertifika sistemi sayesinde daha } \\
\text { güvenilir ve daha kaliteli hale gelmiştir }\end{array}$ & $\square$ & $\square$ & $\square$ & $\square$ & $\square$ \\
\hline $\begin{array}{l}\text { Sertifika sistemi sayesinde, müşteri ile ilişkilerde } \\
\text { iyileşmeler elde edilmiştir }\end{array}$ & $\square$ & $\square$ & $\square$ & $\square$ & $\square$ \\
\hline $\begin{array}{l}\text { Şirketimizin herhangi bir denetleyici tarafından, } \\
\text { incelenip denetlenmesinde bir mahsuru yok }\end{array}$ & $\square$ & $\square$ & $\square$ & $\square$ & $\square$ \\
\hline $\begin{array}{l}\text { Şrketimizde sertifika sistemi kurallarının ihlali çok } \\
\text { nadiren oluyor. }\end{array}$ & $\square$ & $\square$ & $\square$ & $\square$ & $\square$ \\
\hline $\begin{array}{l}\text { Sertifika sistemimi gönül rahatlığı ile diğer şşrket } \\
\text { ve firmalara tavsiye ederim }\end{array}$ & $\square$ & $\square$ & $\square$ & $\square$ & $\square$ \\
\hline $\begin{array}{l}\text { Sertifika sisteminden gelen, kalite yönetim } \\
\text { sistemine yönelik talep ve istekler tam olması } \\
\text { gerektiği gibi }\end{array}$ & $\square$ & $\square$ & $\square$ & $\square$ & $\square$ \\
\hline Bize verilen denetleme sürelerinden memnunuz & $\square$ & $\square$ & $\square$ & $\square$ & $\square$ \\
\hline $\begin{array}{l}\text { Sertifika sistemi uygulamaları şiket yönetimine } \\
\text { bazen çok faydalı bilgiler veriyor }\end{array}$ & $\square$ & $\square$ & $\square$ & $\square$ & $\square$ \\
\hline $\begin{array}{l}\text { Sertifika sistemi uygulaması için yapılan işletme } \\
\text { masrafı ile fayda oranı arasında denge var }\end{array}$ & $\square$ & $\square$ & $\square$ & $\square$ & $\square$ \\
\hline $\begin{array}{l}\text { Gıda perakendecilerinin direktifleri olmasaydı } \\
\text { bile, biz her halükarda sertifika sistemeni } \\
\text { uygalamaya alırdık }\end{array}$ & $\square$ & $\square$ & $\square$ & $\square$ & $\square$ \\
\hline $\begin{array}{l}\text { Sertifika sisteminin uygulanmaya geçme süreci } \\
\text { çin kullanılan zaman çok fazla }\end{array}$ & $\square$ & $\square$ & $\square$ & $\square$ & $\square$ \\
\hline $\begin{array}{l}\text { Sertifika sistemi sayesinde ticari faaliyetlerimizin } \\
\text { akışı daha belirgin, daha açık bir hal almıştır }\end{array}$ & $\square$ & $\square$ & $\square$ & $\square$ & $\square$ \\
\hline
\end{tabular}


25. Daha önce herhangi bir sertifika sisteminden vazgeçip bıraktığınız oldumu?
Evet
Hayır

(Eğer yukarıdaki soruya cevabınız "Evet" ise; A).hangi tecrübe /- lerden dolayı eski sertifika sistemininden Vazgeçtiniz? B). Sonrasında bu Vazgeçme kararınızdan memnunmusunuz? Lütfen cevaplarınızı aşağıdaki kutucuğa yazınız.

26. Şirketiniz sertifika sistemi yapılandırma ve kurma aşamasında hangi ciddi sorunlarla karşılaştı? Lütfen aşağıdaki kutulara üç temel sorunu yazınız.

\begin{tabular}{|l|l|}
\hline 1. & \\
\hline 2. & \\
\hline 3. & \\
\hline
\end{tabular}

27. Aşağıda verilen alanlarda, sertifika sistemini uygulamaya başlama aşamasında şirketinizde ek masraflar ortaya çıktımı ? (Lütfen her ifadeyi değerlendirin ve her ifade için tek bir cevap verin)

\begin{tabular}{|l|c|c|c|c|c|}
\hline & $\begin{array}{c}1 \\
\text { hiç doğru } \\
\text { değil }\end{array}$ & $\begin{array}{c}2 \\
\text { doğru } \\
\text { değil }\end{array}$ & $\begin{array}{c}3 \\
\text { ne doğru } \\
\text { ne yanlış }\end{array}$ & $\begin{array}{c}4 \\
\text { doğru }\end{array}$ & $\begin{array}{c}\text { çok } \\
\text { doğru }\end{array}$ \\
\hline Personel Eğitimi alanında & $\square$ & $\square$ & $\square$ & $\square$ & $\square$ \\
\hline Kayıt tutma zorunluluğu alanında & $\square$ & $\square$ & $\square$ & $\square$ & $\square$ \\
\hline Dış-danışma servisinde & $\square$ & $\square$ & $\square$ & $\square$ & $\square$ \\
\hline Yeni teknik yatırımlarda & $\square$ & $\square$ & $\square$ & $\square$ & $\square$ \\
\hline İdari değişiklikler alanında & $\square$ & $\square$ & $\square$ & $\square$ & $\square$ \\
\hline Altyapı ve bina yenilemede & $\square$ & $\square$ & $\square$ & $\square$ & $\square$ \\
\hline Laboratuvar ve analiz harcamaları alanında & $\square$ & $\square$ & $\square$ & $\square$ & $\square$ \\
\hline Alet ve cihazların ayarlanması ve bakımında & $\square$ & $\square$ & $\square$ & $\square$ & $\square$ \\
\hline Önleyici- koruyucu bakım onarım alanlarında & $\square$ & $\square$ & $\square$ & $\square$ & $\square$ \\
\hline Temizlik personeli alanında & $\square$ & $\square$ & $\square$ & $\square$ & $\square$ \\
\hline Diğer, (lütfen buraya yazınız) & $\square$ & $\square$ & $\square$ & $\square$ & $\square$ \\
\hline
\end{tabular}


28. Aşağıda verilen faaliyetlerin sizin şirketinizde başarılı bir Rekabet Stratejisi için önemi nedir? (Lütfen her ifadeyi değerlendirin ve her ifade için tek bir cevap verin)

\begin{tabular}{|l|c|c|c|c|c|}
\hline & $\begin{array}{c}1 \\
\text { hiç önemli } \\
\text { değil }\end{array}$ & $\begin{array}{c}2 \\
\text { önemli } \\
\text { değil }\end{array}$ & $\begin{array}{c}3 \\
\text { ne önemli nede } \\
\text { önemsiz }\end{array}$ & $\begin{array}{c}4 \\
\text { önemli }\end{array}$ & $\begin{array}{c}5 \\
\text { çok } \\
\text { önemli }\end{array}$ \\
\hline $\begin{array}{l}\text { Iş̧ akışı etkinliği ve çalışma sürecinin etkinliğini kalıcı } \\
\text { olmasını temin etmeye çalışıyoruz }\end{array}$ & $\square$ & $\square$ & $\square$ & $\square$ & $\square$ \\
\hline $\begin{array}{l}\text { Şirketimiz hammaddeyi uygun fiyatlarda tedarik } \\
\text { etmektedir }\end{array}$ & $\square$ & $\square$ & $\square$ & $\square$ & $\square$ \\
\hline $\begin{array}{l}\text { Şirketimiz ürünlerde yenilikçi pazar anlayışını } \\
\text { benimsemektedir }\end{array}$ & $\square$ & $\square$ & $\square$ & $\square$ & $\square$ \\
\hline Ürünlerimizi piyasaya ucuz fiyatlarda sunuyoruz & $\square$ & $\square$ & $\square$ & $\square$ & $\square$ \\
\hline $\begin{array}{l}\text { Marka- müşteri ilişkisini ticaretimizde güncel tutmaya } \\
\text { çalışıyoruz }\end{array}$ & $\square$ & $\square$ & $\square$ & $\square$ & $\square$ \\
\hline $\begin{array}{l}\text { Uluslararası rekabette maliyet liderliği stratejisini } \\
\text { amaçlayarak, ürünlerimizi çok uygun fiyatlarda piyasaya } \\
\text { sunuyoruz }\end{array}$ & $\square$ & $\square$ & $\square$ & $\square$ & $\square$ \\
\hline $\begin{array}{l}\text { Farklılıştırma stratejisini uygulayarak, uluslararası } \\
\text { rekabette ürünlerimizin kalitede ve yenilikçilikte önderlik } \\
\text { amaçlıyoruz }\end{array}$ & $\square$ & $\square$ & $\square$ & $\square$ & $\square$ \\
\hline $\begin{array}{l}\text { Uluslararası rekabette odaklaşma stretejisini kullanarak, } \\
\text { belirli tüketici grubuna ulaşmayı hedefliyoruz }\end{array}$ & $\square$ & $\square$ & $\square$ & $\square$ & $\square$ \\
\hline $\begin{array}{l}\text { Genellikle şirketimiz, rakiplerimizden önce piyasaya yeni } \\
\text { ürünler sunmaktadır }\end{array}$ & $\square$ & $\square$ & $\square$ & $\square$ & $\square$ \\
\hline
\end{tabular}

29. Şirketinizin "Kurumsal sosyal sorumluluk" konusundaki yaklaşımı nedir? (Aşağıdaki ifadeleri siz nasıl değerlendiriyorsunuz? (Lütfen her ifadeyi değerlendirin ve her ifade için tek bir cevap verin)

\begin{tabular}{|l|c|c|c|c|c|}
\hline & $\begin{array}{c}1 \\
\text { kesinlikle } \\
\text { katılmı- } \\
\text { yorum }\end{array}$ & $\begin{array}{c}2 \\
\text { katılmı- } \\
\text { yorum }\end{array}$ & $\begin{array}{c}3 \\
\text { farket- } \\
\text { mez }\end{array}$ & $\begin{array}{c}4 \\
\text { katılı- } \\
\text { yorum }\end{array}$ & $\begin{array}{c}5 \\
\text { kesinlikle } \\
\text { katılı- } \\
\text { yorum }\end{array}$ \\
\hline $\begin{array}{l}\text { Kurumsal sosyal sorumluluk pazarlama stratejimizin önemli } \\
\text { bir parçasıdır }\end{array}$ & $\square$ & $\square$ & $\square$ & $\square$ & $\square$ \\
\hline $\begin{array}{l}\text { Sertifikanın kurumsal sosyal sorumluluk yaklaşımını ve } \\
\text { anlayışını mantıklı buluyoum }\end{array}$ & $\square$ & $\square$ & $\square$ & $\square$ & $\square$ \\
\hline Şirketimiz kamu tarafından eleştiri alıyor & $\square$ & $\square$ & $\square$ & $\square$ & $\square$ \\
\hline $\begin{array}{l}\text { Birlikte çalışsığımız teslimatçır ve müşterilerimiz şirketimizin } \\
\text { dürüst ve adil işbirliğini takdir ediyorlar }\end{array}$ & $\square$ & $\square$ & $\square$ & $\square$ & $\square$ \\
\hline $\begin{array}{l}\text { Bazı ürünlerimizin özelliklerinden (yağ, şeker, alkohol } \\
\text { içerikleri) dolayı şirketimize büyük baskı görüyor }\end{array}$ & $\square$ & $\square$ & $\square$ & $\square$ & $\square$ \\
\hline $\begin{array}{l}\text { Şirketimizin çevreye verdiği etkilerinden dolayı ağır } \\
\text { eleştirilere maruz kalıyoruz ( hava emisyonu, atık su) }\end{array}$ & $\square$ & $\square$ & $\square$ & $\square$ & $\square$ \\
\hline $\begin{array}{l}\text { Şrketimizin adalet ve dürüstlük anlayışı genellikle bilinir ve } \\
\text { takdir edilir }\end{array}$ & $\square$ & $\square$ & $\square$ & $\square$ & $\square$ \\
\hline $\begin{array}{l}\text { Şirket çalışanlarımızı desteklemeye ve gelişimlerine büyük } \\
\text { önem veriyoruz (şirket içi eğitim gibi) }\end{array}$ & $\square$ & $\square$ & $\square$ & $\square$ & $\square$ \\
\hline $\begin{array}{l}\text { Şirketimizin ticari partnerleri ile bölgesel ve yöresel olarak } \\
\text { çok iyi ve çok yakın iş ilişkileri vardır }\end{array}$ & $\square$ & $\square$ & $\square$ & $\square$ & $\square$ \\
\hline Şirketimiz çok iyi ve çok belirgin bir çevre bilincine sahiptir & $\square$ & $\square$ & $\square$ & $\square$ & $\square$ \\
\hline $\begin{array}{l}\text { Şrketimiz için ,sosyal sorumluluk en az şirket kazancı kadar } \\
\text { önem taşıyor. }\end{array}$ & $\square$ & $\square$ & $\square$ & $\square$ & $\square$ \\
\hline Şirketimiz çevre örgütleri ile birlikte çalışıyor & $\square$ & $\square$ & $\square$ & $\square$ & $\square$ \\
\hline
\end{tabular}




\section{Bölüm 4: Sosyo- Demografik Sorular}

Bu kısımda anketi dolduran kişi ile ilgili sorular olucaktır.

30. Şirketinizin (çoğunlukla) hangi bölümünde çalışıyorsunuz?

\begin{tabular}{|l|}
\hline$\square$ Şirket sahibi \\
\hline$\square$ Şirket yöneticisi \\
\hline$\square$ Alım- satım bölümünde \\
\hline$\square$ Dış ticaret bölümünde (ithalat- ihracat) \\
\hline$\square$ Kalite yönetimi bölümünde \\
\hline$\square$ Pazarlama bölümünde \\
\hline$\square$ Diğer \\
\hline
\end{tabular}

31. Eğitim durumunuz nedir?

\begin{tabular}{|l|l|}
\hline$\square$ ilkokul mezunu & $\square$ Halk eğitim merkezi (usta, tekniker) \\
\hline$\square$ Ortaokul mezunu & $\square$ Önlisans/ Yüksek Okul mezunu \\
\hline$\square$ Lise mezunu & $\square$ Master \\
\hline$\square$ Ünıversite mezunu & $\square$ Doktora \\
\hline$\square$ Hiç mezuniyet yok & $\square$ Diğer \\
\hline
\end{tabular}

\begin{tabular}{|l|l|l|}
\hline Cinsiyetiniz: & $\square$ Kadın & $\square$ Erkek \\
\hline
\end{tabular}

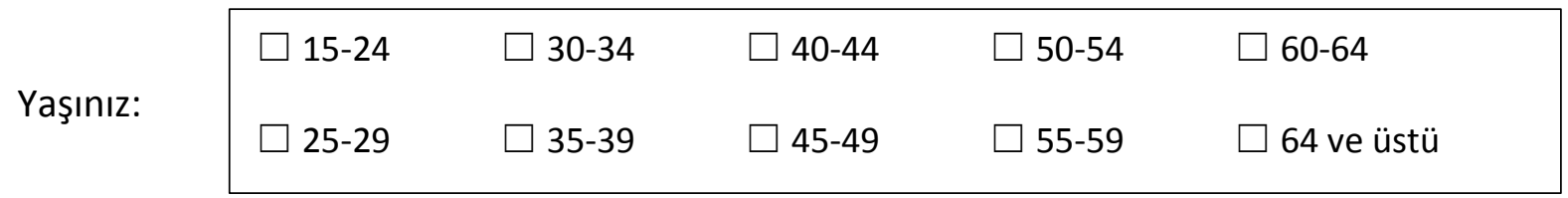

Anketin bitiş saati:

: 


\section{Ekler:}

Soru $16^{\prime}$ ya yönelik açıklama:

Kaynak : Türkiye Cumhuriyeti Ekonomi Bakanlığı

Başlık: Dünya üzerindeki bölgelerin ülkelere göre dağılımı

1) Avrupa: Almanya, Arnavutluk, Avusturya, Belçika, Bosna- Hersek, Bulgaristan, Çek

Cumhuriyeti, Danimarka, Finlandiya, Fransa, Hırvatistan, Hollanda, İngiltere, İrlanda, İspanya, İsveç, İsviçre, İtalya, Karadağ, KKTC, Kosova, Litvanya, Macaristan, Makedonya, Norveç, Polonya, Portekiz, Romanya, Sırbistan, Slovakya, Slovenya, Yunanistan.

2) Asya- Pasifik: Afganistan, Avustralya, Bangladeş, Çin Halk Cumhuriyeti, Endonezya, Filipinler, Güney Kore, Hindistan, Hong Kong, Japonya, Malezya, Moğolistan, Pakistan, Singapur, Tayland, Vietnam, Yeni Zelanda

3) Avrasya: Azerbaycan, Beyaz Rusya, Gürcistan, İran, Kazakistan, Kırgızistan, Maldova, Özbekistan, Rusya Federasyonu, Tacikistan, Türkmenistan, Ukrayna

4) Ortadoğu- Kuzey Afrika: BAE, Bahreyn, Cezayir, Fas, Filistin, Irak, İsrail, Katar, Kuveyt, Libya, Lübnan, Mısır, Suriye, Suudi Arabistan, Tunus, Umman, Ürdün, Yemen

5) Sahra Altı Afrika: Angola, Demokratik- Kongo, Etiyopya, Gana, G. Afrika Cumhuriyeti, Güney Sudan, Kamerun, Kenya, Madagaskar, Mali, Mozambik, Nijerya, Senegal, Sudan, Tanzanya, Uganda, Zambia

6) Amerika: ABD, Arjantin, Brezilya, Kanada, Kolombiya, Küba, Meksika, Peru, Şili; Venezuella 


\section{Deskriptive Ergebnisse}

199 Unternehmen haben teilweise, davon 106 Unternehmen vollständig die Online-Befragung beantwortet. Bei 156 Unternehmen befindet sich der Unternehmenssitz in Zentralanatolien. Weiterhin befinden sich jeweils 12 Unternehmen in der Mittelmeerregion und der ägäischen Region, 27 Unternehmen in der Marmara-Region, 16 Unternehmen in der Schwarzmeer-Region, drei Unternehmen in Südostanatolien und nur ein Unternehmen in Ost-Anatolien.

\section{Unternehmenssitz nach Regionen}

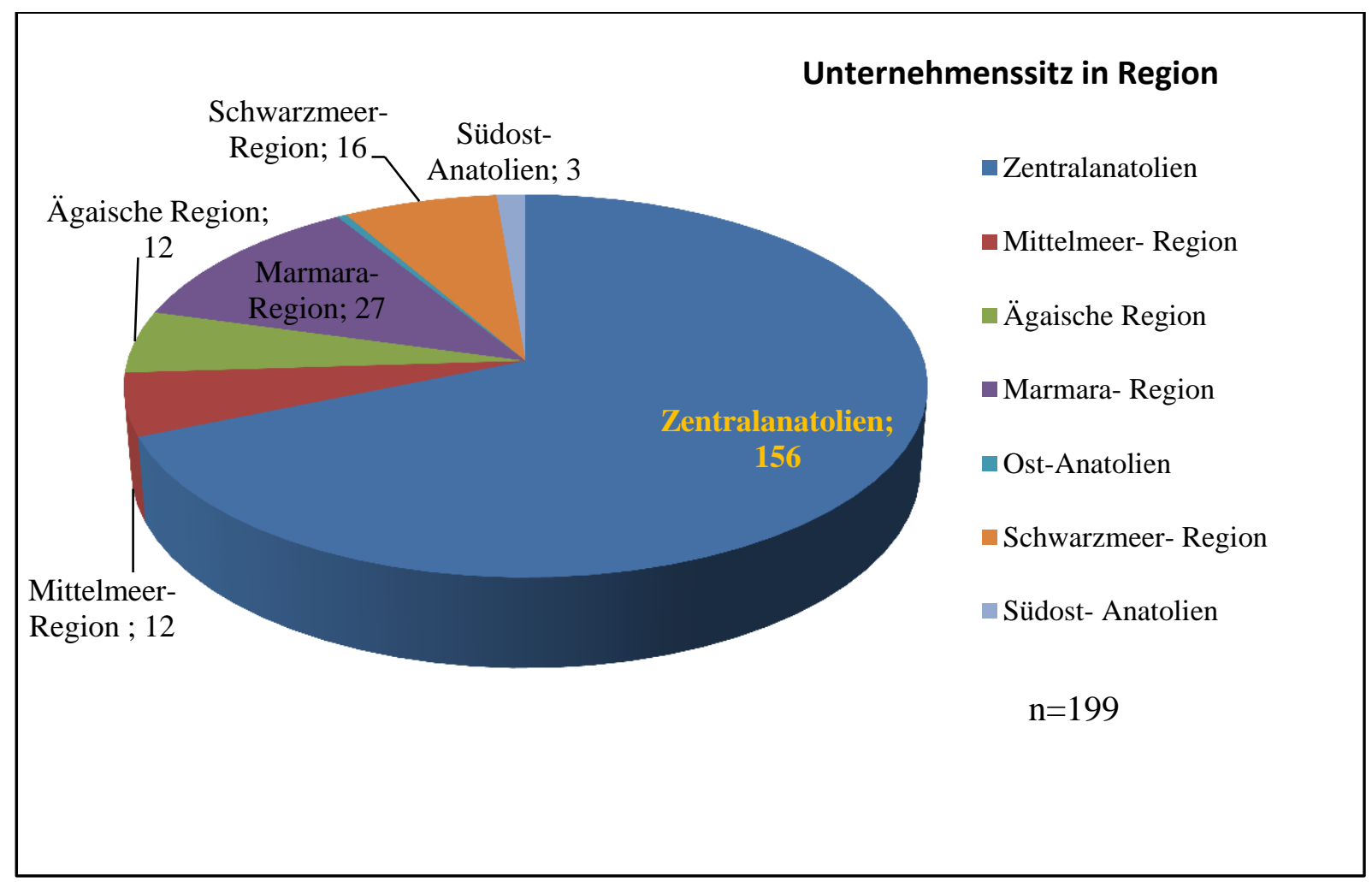

Quelle: Eigene Berechnungen

(Mehrfach-Antworten waren möglich)

Soziodemographische Fragen: $41 \%$ der Befragten sind Geschäftsleiter bzw. Geschäftsinhaber (23 bzw. 18 Personen), 16\% sind im Bereich Qualitätsmanagement, 15 \% im Bereich Produktion tätig. 68\% der befragten Absolventen haben einen Universitäts- oder Masterabschluss, 15\% haben Abitur, ca. $13 \%$ haben einen vergleichbaren Bachelorabschluss. Von den Befragten sind 77,3 \% männlich, 22,7 \% weiblich. 42,9\% der Befragten sind in der Altersklasse zwischen 3039 Jahren, 21,4 \% der Auskunftspersonen sind jünger als 30 Jahre, 20,4 \% sind zwischen 40 und 49 Jahren, 15,3 \% sind älter als 50 Jahre. 


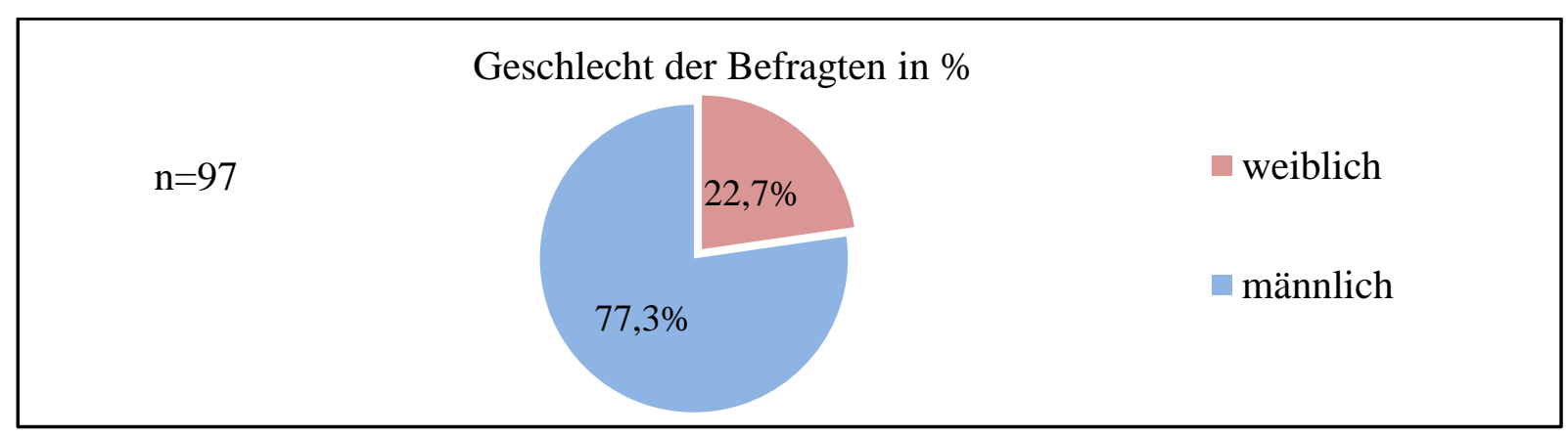

\section{Ausbildungsabschluss der Befragte}

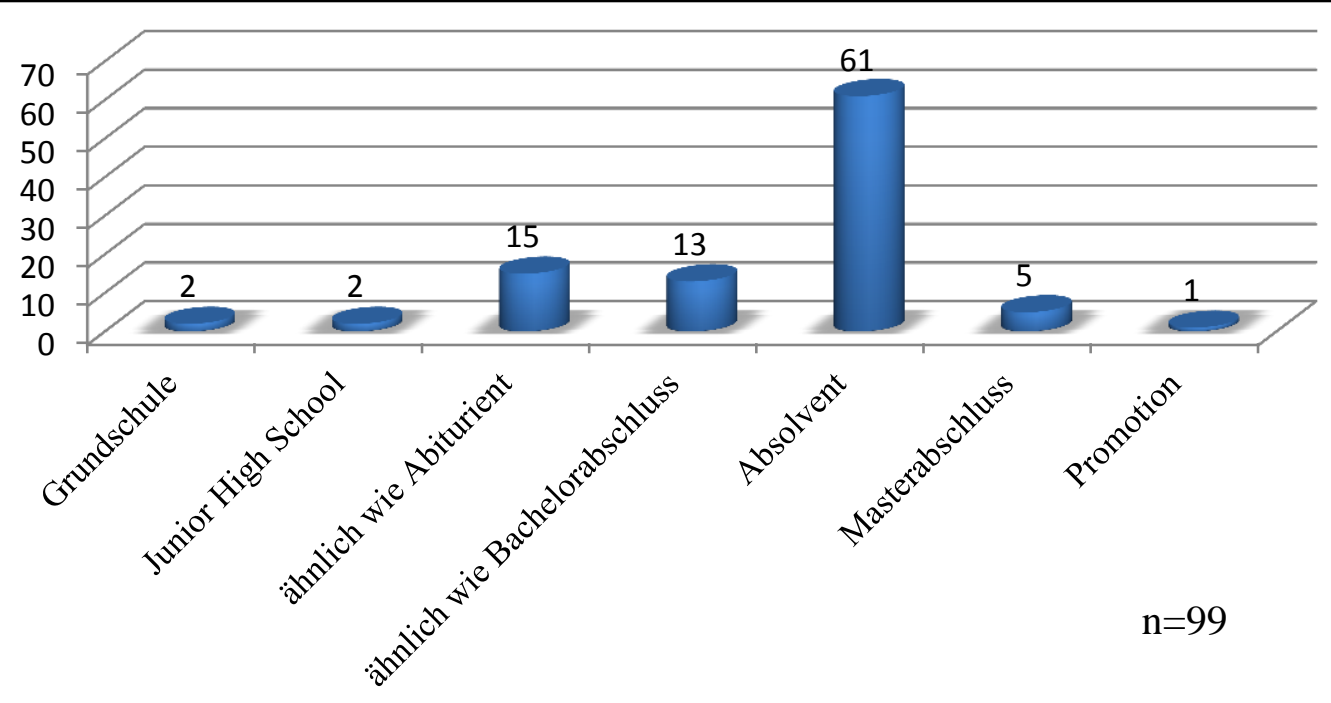

Quelle: Eigene Berechnungen

\section{Altersklassen der Befragte (in \%)}

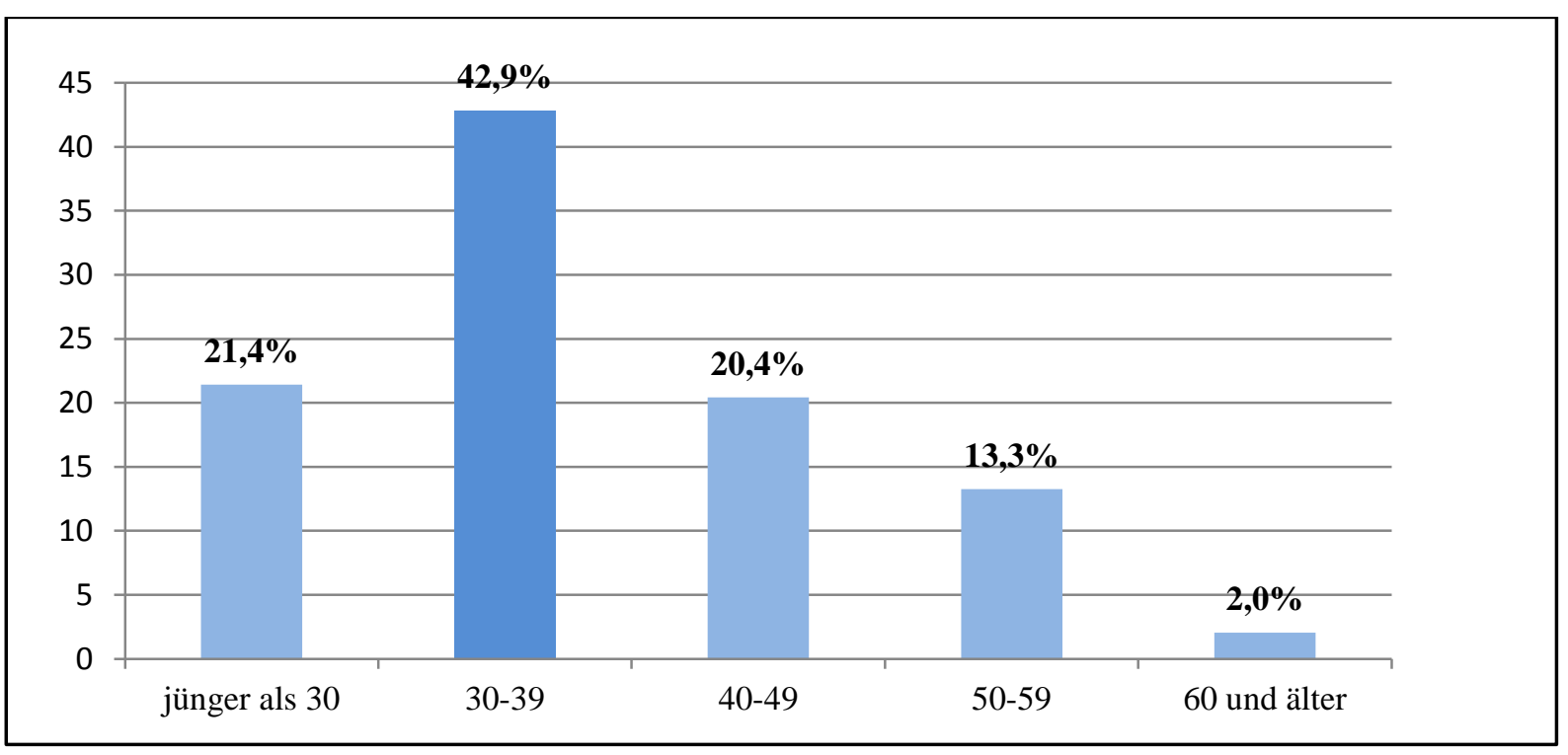

Quelle: Eigene Berechnungen 


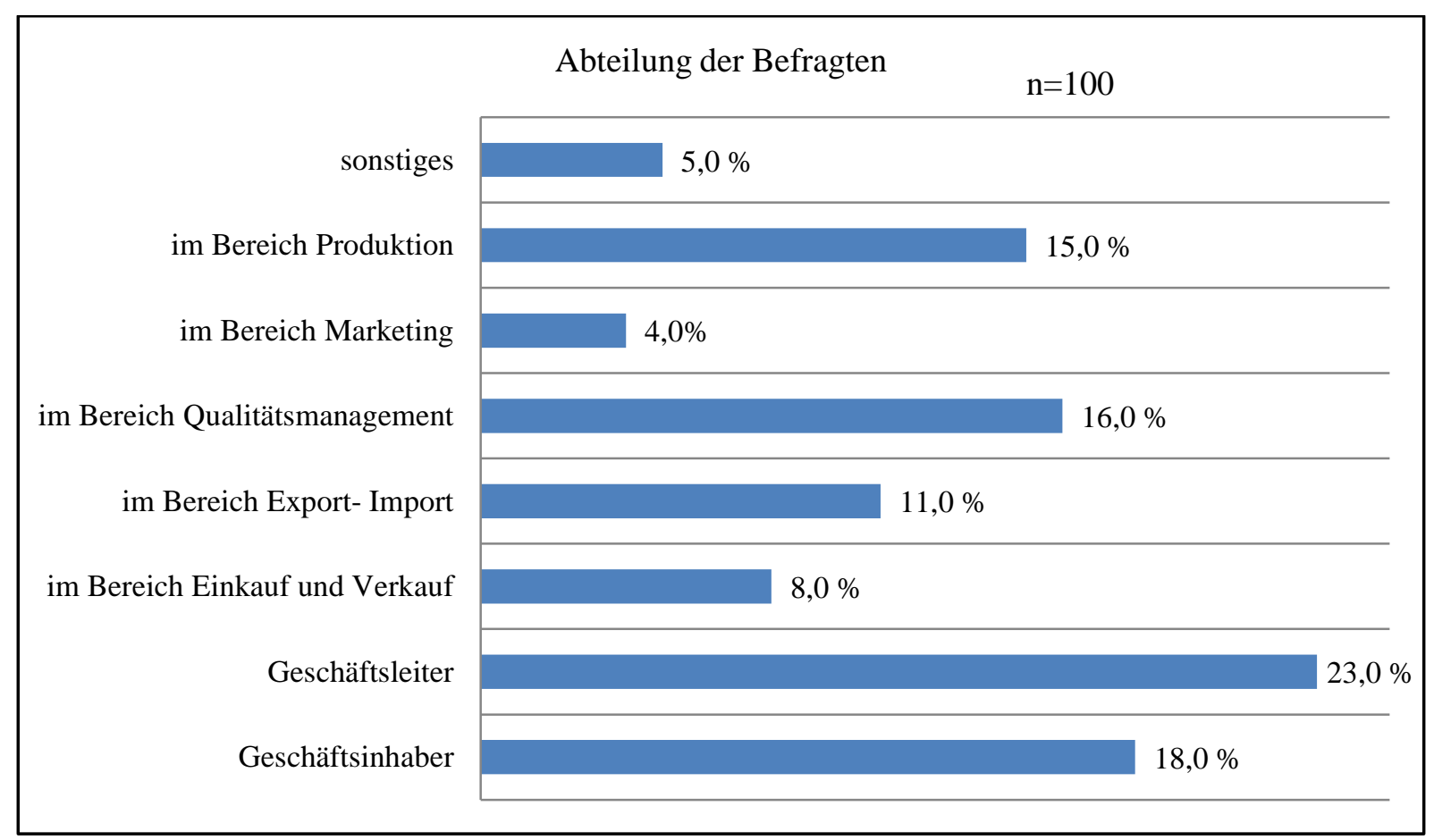

Quelle: Eigene Berechnungen

\section{a) Tätigkeitsfelder und Größe der Unternehmen}

In diesem Kapitel werden zwei Untersuchungsparameter erfasst: Verarbeitungszweige und Umsätze des Unternehmens.

Bei der Frage Verarbeitungszweige sind die ersten drei eingegebenen Antworten auffallend. 66 Unternehmen haben Mahl- und Schälmühlen, 58 Unternehmen erzeugen Süß- und Schokoladenwaren und 40 Unternehmen haben Sonstiges angekreuzt. Unter dem Begriff Sonstiges gehört z.B. Kuruyemiş (ähnlich wie in Deutschland das „Studentenfutter“), verschiedene Soßen, Imkerprodukte, verschiedene Inhaltsstoffe wie Bäckerhefe, Enzyme für Milchprodukte, Brotsorten, Blätterteig und Kekse. 


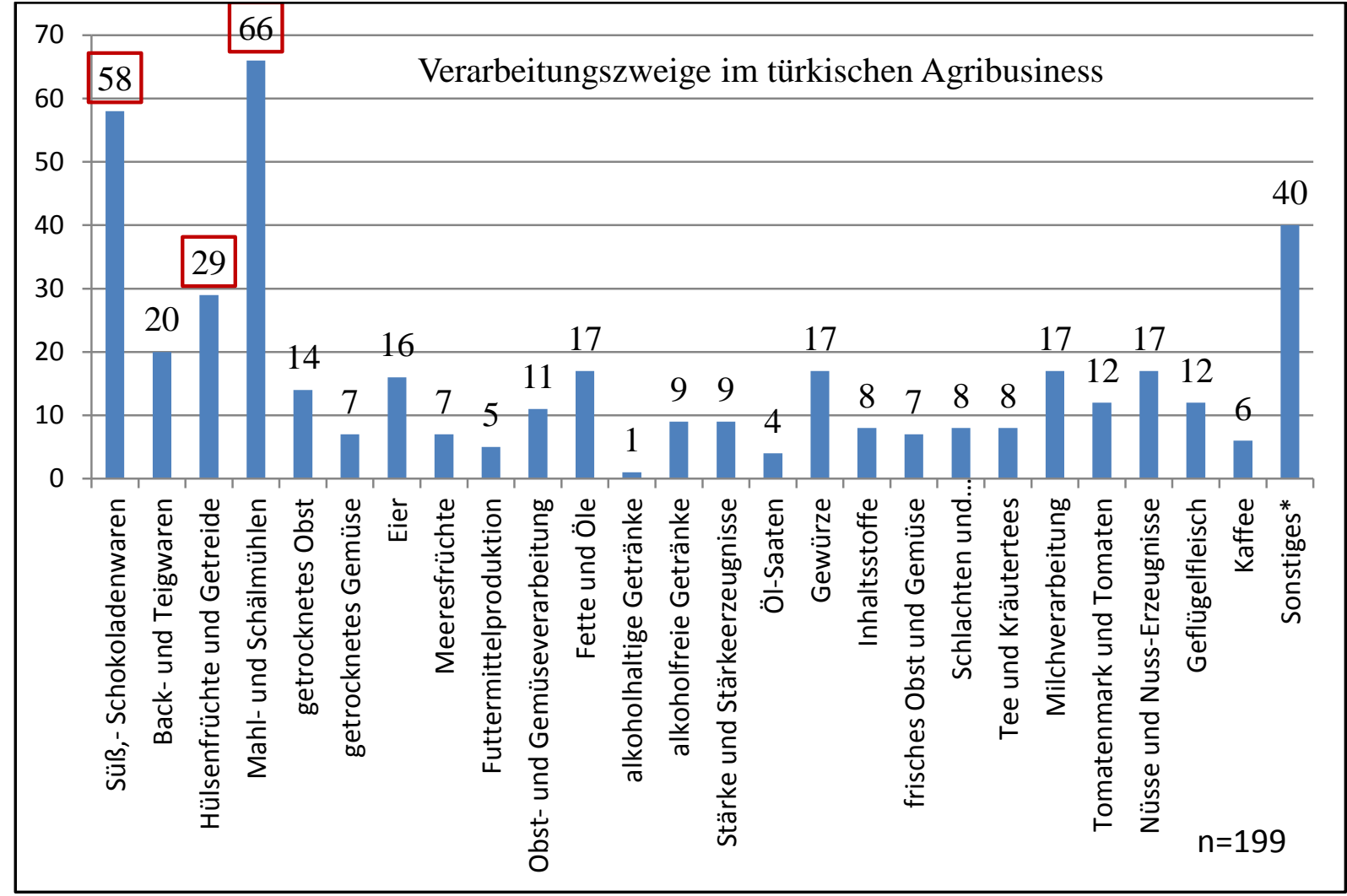

Quelle: Eigene Berechnung

(Mehrfach-Antworten waren möglich)

Die Frage nach dem Umsatz des Unternehmens in den vergangenen drei Jahren wurde als offene Frage gestellt. Dies liegt daran, dass zunächst viele gestartete Befragungen gerade hier abgebrochen wurden, weil viele Unternehmen ihre Umsätze nicht mitteilen wollten. Die Umsätze sind in fünf Gruppen aufgeteilt und damit besser verständlich. Die größte Gruppe befindet sich im Bereich zwischen 500.000 Euro bis 5 Mio. Euro. Jedes Jahr sind die Unternehmensumsätze dabei gestiegen. Im Jahr 2012 haben sechs Unternehmen mehr als 80 Mio. Euro Umsatz gemacht. 


\section{Umsätze der Unternehmen von 2010-2012}

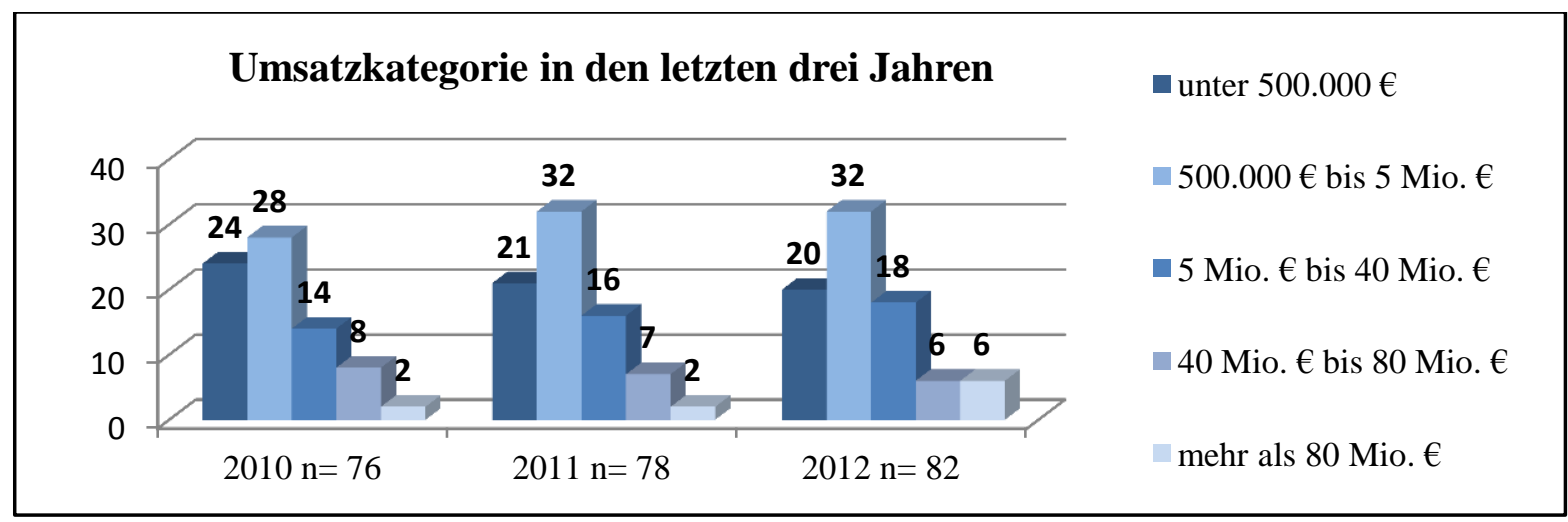

Quelle: Eigene Berechnungen

\section{b) Internationalisierungsgrad, Handelsbeziehungen mit EU- und Nicht-EU-Ländern}

$\mathrm{Ab}$ dem Jahr 2005 ist eine verstärkte Exportorientierung zu beobachten. Seinerzeit wurden die offiziellen Beitrittsverhandlungen mit der EU aufgenommen und in diesem Jahr sind alleine 13 Unternehmen in den ausländischen Markt eingetreten. Zwischen 2006 und 2010 sind 29 und zwischen 2011 bis 201316 Unternehmen im Ausland aktiv geworden. In den Jahren 1991 bis 2000 wurde mit 20 Unternehmen auch eine relativ hohe Zahl an Betrieben im Auslandsmarkt aktiv; dies mag daran liegen, dass die damalige Regierung in den 1990er Jahren kleine und mittlere Unternehmen gefördert hat.

Verteilung des Eintrittsjahrs in ausländische Märkte (absolute Einheiten)

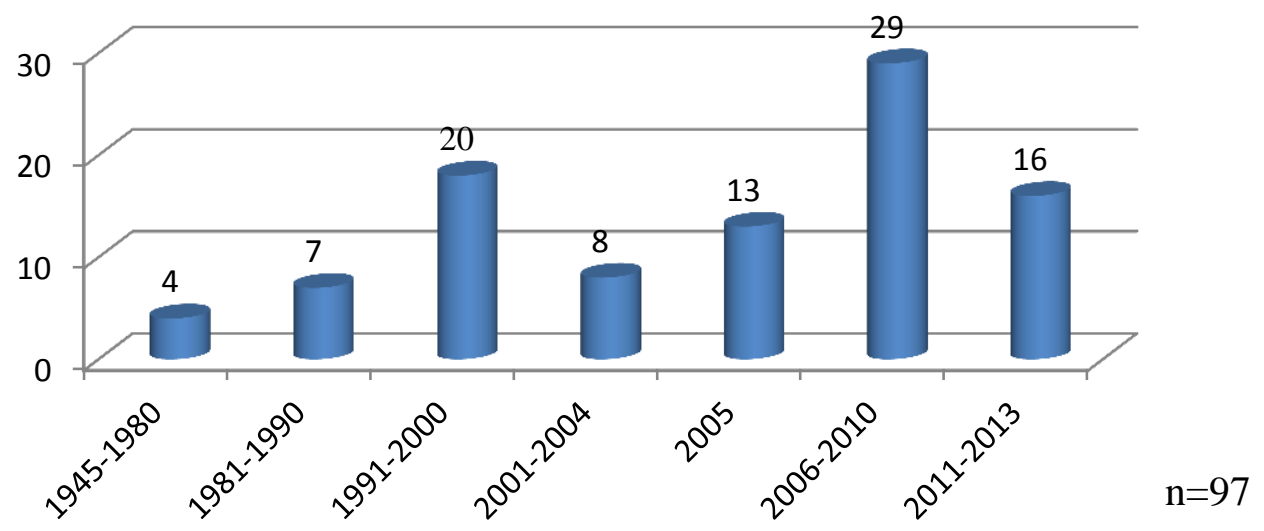

Quelle: Eigene Berechnungen

Internationalisierung: Knapp 30\% der befragten Unternehmen erwirtschaften ihren Umsatz ausschließlich im Inland, $3 \%$ nur im Ausland, $47 \%$ der Unternehmen haben einen Exportanteil unter $50 \%$. 


\section{Umsatzanteil auf ausländischen Märkten (in \%)}

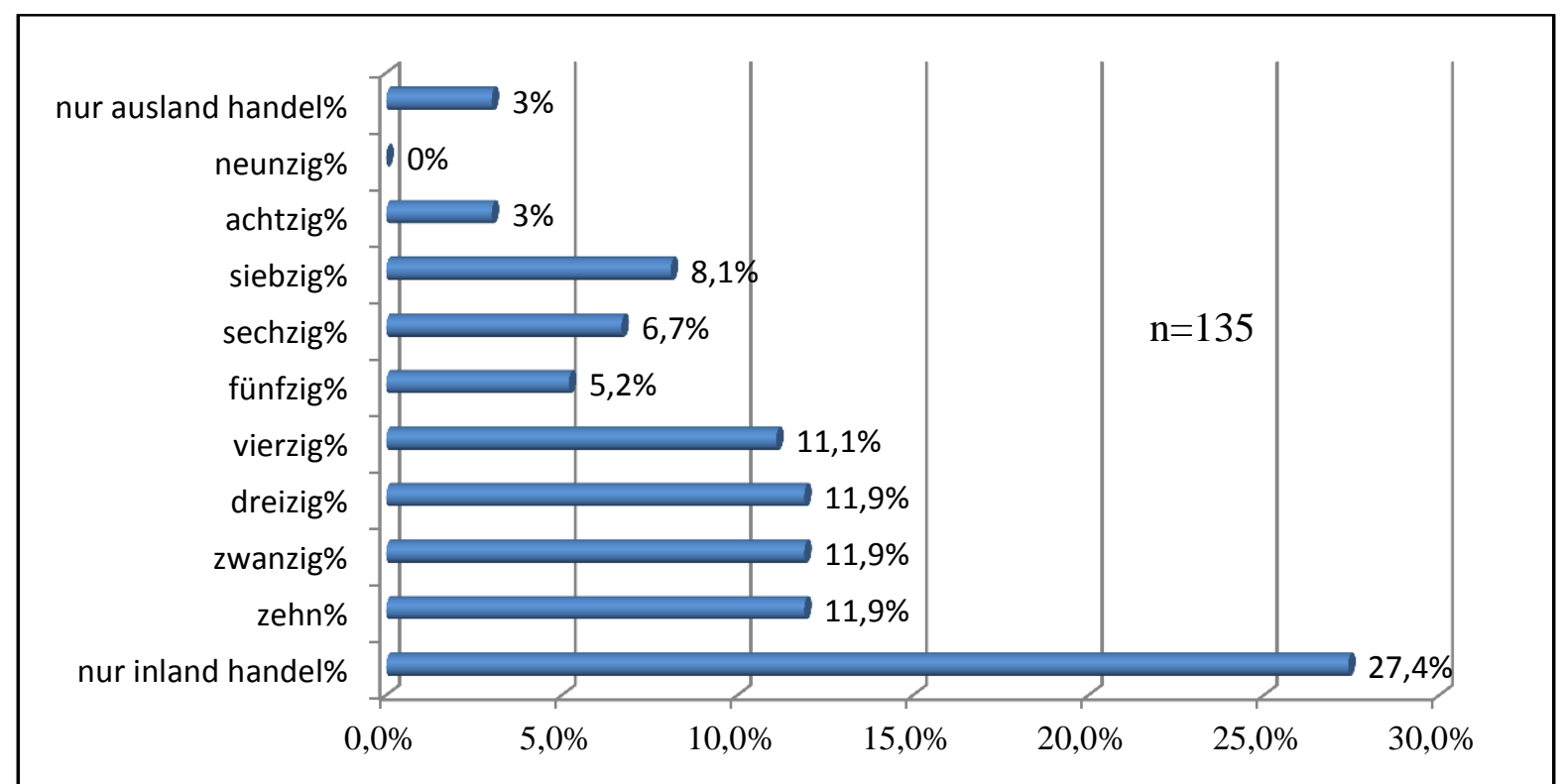

Quelle: Eigene Berechnungen

Die fünf umsatzstärksten Exportprodukte: Sie wurden als offene Fragen gestellt. In der unten stehenden Tabelle sind die umsatzstärksten Exportprodukte nach der Rangfolge der Nennungen aufgeführt. 


\section{Die umsatzstärksten Exportprodukte}

\begin{tabular}{|c|l|}
\hline $\begin{array}{c}\text { Rangfolge der um- } \\
\text { satzstärksten } \\
\text { Exportprodukte }\end{array}$ & \multicolumn{1}{c|}{ Die häufigsten Exportprodukte } \\
\hline $\begin{array}{l}\text { Rang 1 } \\
(\mathrm{n}=96)^{*)}\end{array}$ & $\begin{array}{l}\text { 29 Unternehmen für Süß- und Schokoladenwaren (Schokolade, Cocolin, } \\
\text { Lollipops, Fruchtgummis, Lokum, Halva, Tahin); } \\
\text { 21 Unternehmen für Back- und Teigwaren, 16 Unternehmen für Mahl- } \\
\text { und Schälmühlen, (6) Eier, (7) gefrorenes Fleisch, (6) Inhaltsstoffe, } \\
\text { (4) Kuruyemiş, (4) Gewürze, (3) Getreide, (3) frisches Obst und Gemüse, (10) } \\
\text { Sonstiges; }\end{array}$ \\
\hline $\begin{array}{l}\text { Rang 2 } \\
(\mathrm{n}=78)^{*}\end{array}$ & $\begin{array}{l}\text { 28 Unternehmen für Süß- und Schokoladenwaren (Lokum, Cookies, } \\
\text { Cocolin, Sesam Hartbonbons); } \\
\text { (10) gefrorene Produkte (9) Mahl- und Schälmühlen, (6) Tomatenmark, } \\
\text { (5) Back- und Teigwaren, (5) Getreide, (15) Sonstiges; }\end{array}$ \\
\hline $\begin{array}{l}\text { Rang 3 } \\
(\mathrm{n}=57)^{*}\end{array}$ & $\begin{array}{l}\text { 26 Unternehmen für Süß- und Schokoladenwaren, (8) Kuruyemiş, } \\
\text { (7) gefrorene Produkte, (3) Back- und Teigwaren, (3) Getreide, } \\
\text { (3) Gewürze, (7) Sonstiges; }\end{array}$ \\
\hline $\begin{array}{l}\text { Rang 4 } \\
(\mathrm{n}=36)^{*}\end{array}$ & $\begin{array}{l}\text { 14 Unternehmen für Süß- und Schokoladenwaren, (6) Kuruyemiş, } \\
\text { (3) Gewürze, (3) Getreide, (10) Sonstiges; }\end{array}$ \\
\hline $\begin{array}{l}\text { Rang 5 } \\
(\mathrm{n}=13)^{*}\end{array}$ & $\begin{array}{l}\text { (3) Schokoladenwaren; } \\
\text { (3) Backwaren, (4) Kuruyemiş, (3) Sonstiges; }\end{array}$ \\
\hline Frage: Bitte nennen Sie uns Ihre fünf umsatzstärksten Exportprodukte. \\
\hline
\end{tabular}

Quelle: Eigene Berechnungen

( $\mathrm{n}=$ Anzahl der beteiligten Unternehmen) 


\section{Länder als Absatzmärkte im türkischen Agribusiness}

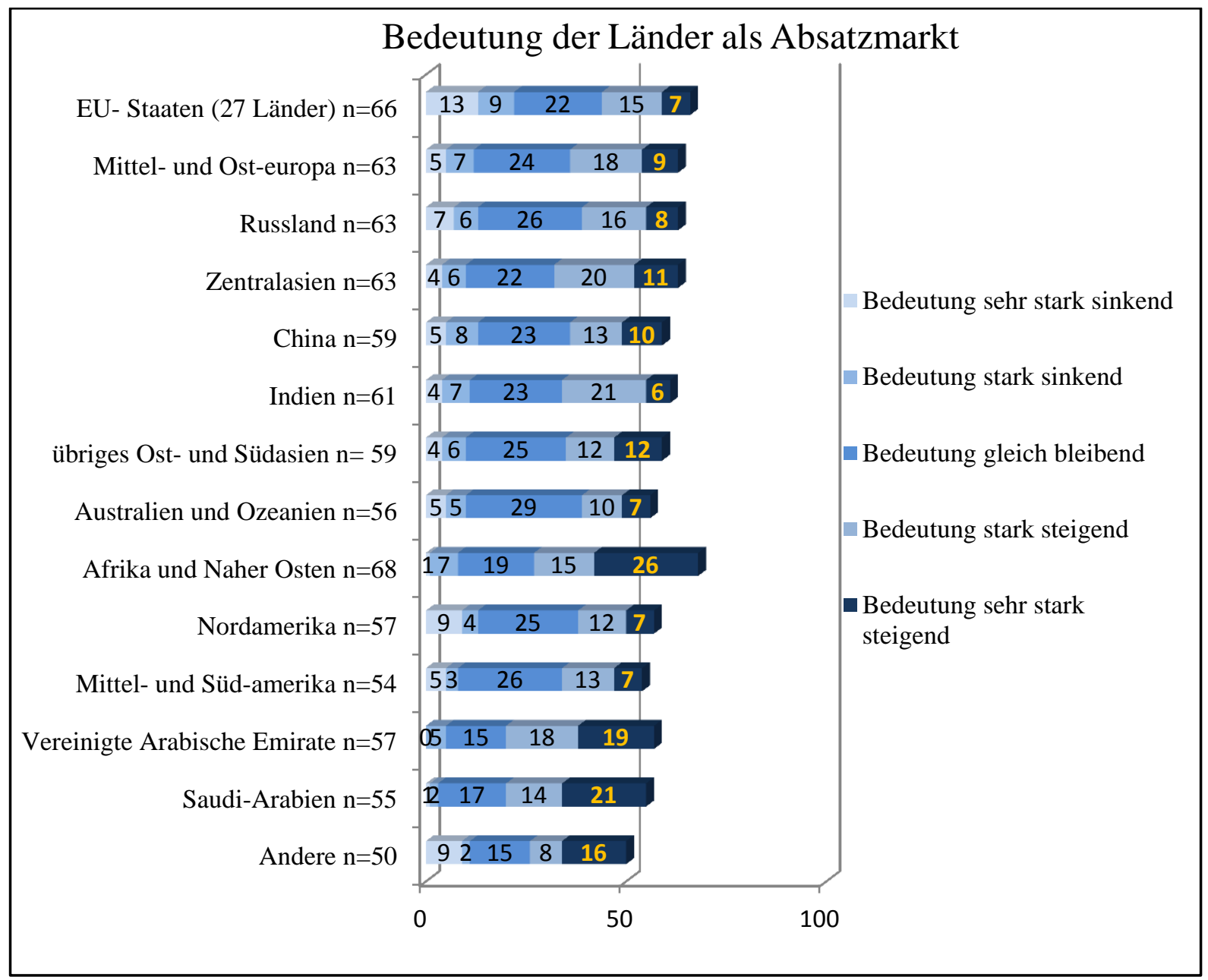

Quelle: Eigene Berechnungen

Länder als Absatzmärkte im türkischen Agribusiness: Die Unternehmen haben vielfach angegeben, dass die EU-Länder (einschließlich der Schweiz und Skandinavien, insgesamt 27 Länder) als Absatzmärkte an Bedeutung verlieren (jeweils 22 Unternehmen haben die Frage mit „stark sinkend“ bzw. „sehr stark sinkend“ beantwortet). Bezüglich Afrika und Naher Osten haben sie am meisten „Bedeutung stark steigend“ angekreuzt (41 Unternehmen haben die Frage mit „Bedeutung stark steigend“ bzw. mit „,sehr stark steigend“ beantwortet). 
Diese Abbildung zeigt die Verteilung der zertifizierten Produkte differenziert nach Kunden und Regionen.

\section{Kunden und Regionen für zertifizierte Produkte}

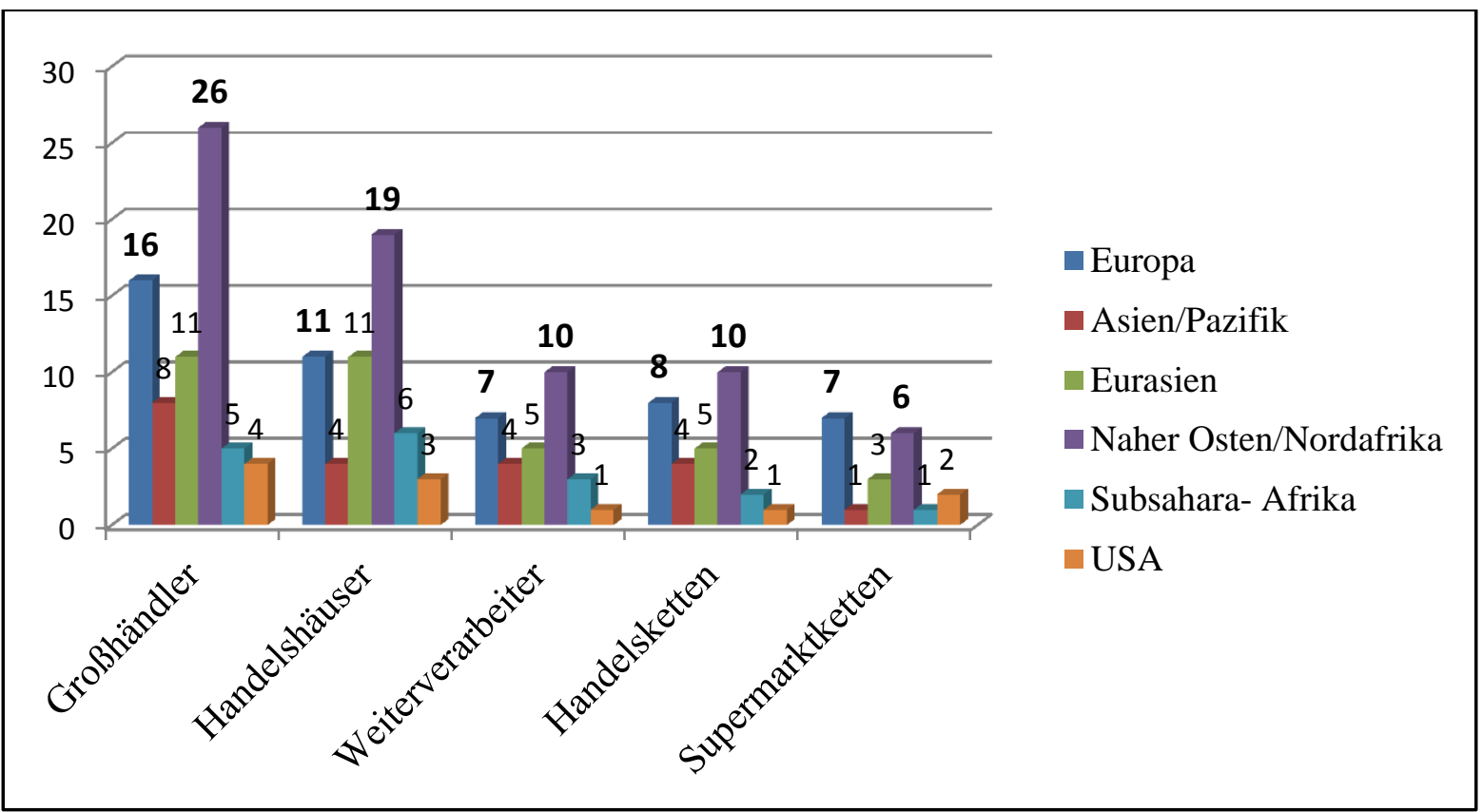

Quelle: Eigene Berechnung

In dieser Abbildung wird deutlich, dass als Kunden zunächst die Großhändler an erster Stelle stehen, danach die Handelshäuser, anschließend die Weiterverarbeiter, die Handelsketten und die Supermarktketten. Die zertifizierten Produkte werden meistens in den Nahen Osten/Nordafrika exportiert, dann nach Europa und als drittes nach Eurasien und schließlich nach SubsaharaAfrika und zum Schluss in die USA. In den Nahen Osten/Nordafrika exportieren zumeist Großhändler, danach Handelshäuser.

\section{c) Zertifizierungssysteme in der türkischen Agrar- und Ernährungswirtschaft}

Es zeigt sich, dass die meisten Unternehmen (76) nach dem türkischen Lebensmittel-Kodex gesetzlich zertifiziert sind, 67 Unternehmen sind nach ISO-Normen zertifiziert. 62 Unternehmen haben ein HACCP-Konzept und 55 Unternehmen ein Halal-Zertifikat. 10 Unternehmen sind BRC-, aber nur 7 Unternehmen nach IFS zertifiziert. Weiterhin gab es noch die Möglichkeit, andere Zertifizierungssysteme anzugeben (z.B. AIB, FSSC 22000 etc.). Dabei waren Mehrfachantworten möglich. 


\section{Zertifizierungssysteme im türkischen Agribusiness}

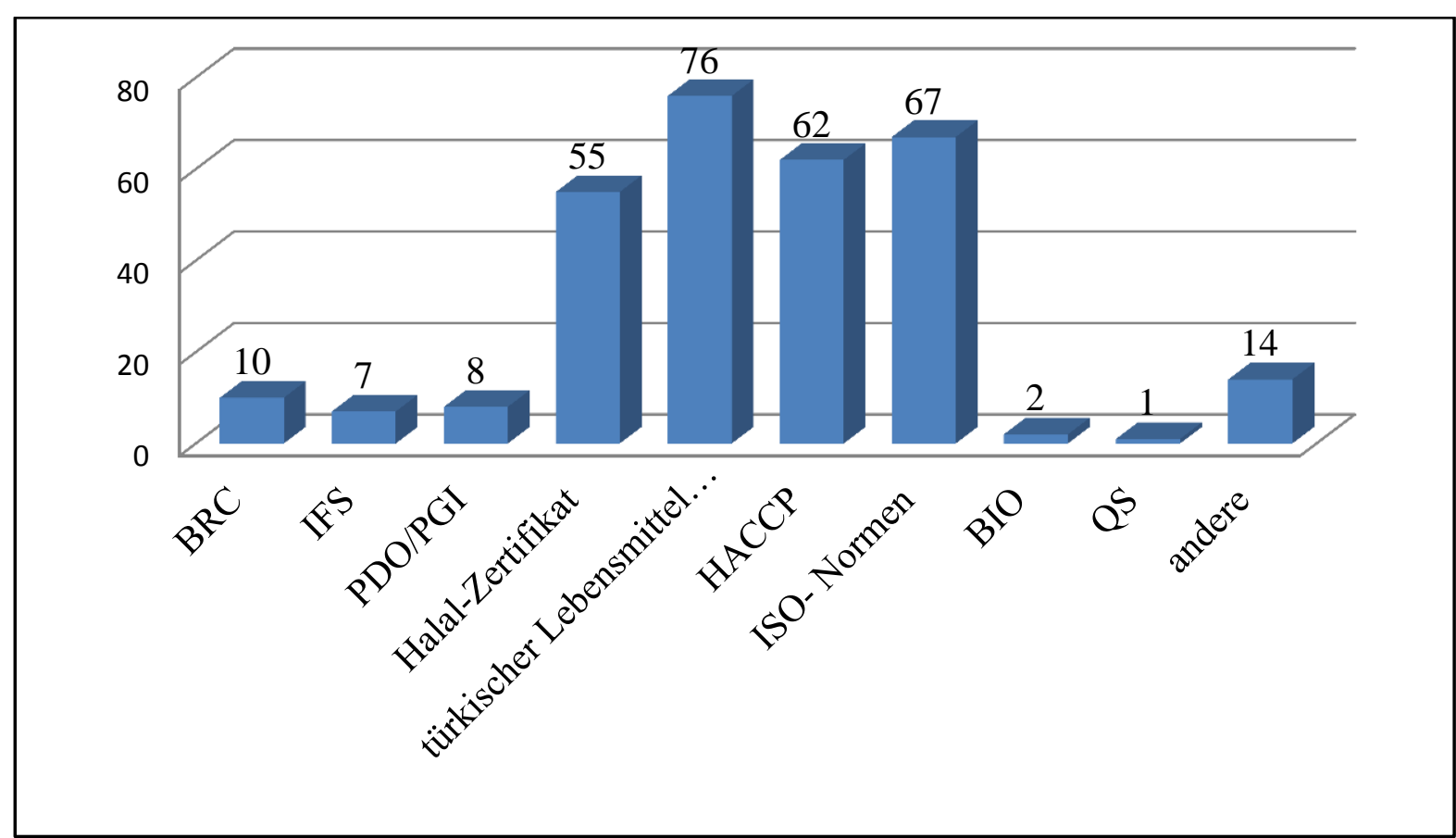

Quelle: Eigene Berechnungen

(Mehrfach-Antworten waren möglich)

In der nachfolgenden Tabelle werden die ISO-Normen im türkischen Agribusiness aufgeführt. Im Fragebogen bestand die Möglichkeit, aus insgesamt sieben vorgegebenen ISO-Normen zu wählen. Als weitere Option konnte eine andere ISO-Norm angegeben werden. Dabei fällt auf, dass die meisten Unternehmen nach ISO 22000 und ISO 9001 zertifiziert sind. Immerhin 10 Unternehmen haben andere ISO-Normen angegeben.

\section{ISO-Normen im türkischen Agribusiness}

\begin{tabular}{|l|c|}
\hline ISO-Normen & $\begin{array}{c}\text { Anzahl der } \\
\text { Unternehmen }\end{array}$ \\
\hline ISO 22000: Managementsystem für die Lebensmittelsicherheit & 58 \\
\hline ISO 9001: Qualitätsmanagementsysteme & 56 \\
\hline ISO 14001: Umweltmanagementsystem & 20 \\
\hline ISO 13001: Anforderungen der Maschinenrichtlinie 2006/42/EG. & 15 \\
\hline $\begin{array}{l}\text { ISO 15161: Anwendung von ISO 9001 in der Lebensmittel- und Getränkein- } \\
\text { dustrie; } \quad \text { Geschaffung, Verarbeitung, und Verpackung von Lebensmittel und }\end{array}$ & 11 \\
\hline ISO 18001: Arbeitsschutzmanagementsystem & 6 \\
\hline ISO 17025: Allgemeine Anforderungen an die Kompetenz von Prüf-und & 6 \\
\hline Kalibrierlaboratorien & 10 \\
\hline
\end{tabular}

Quelle: Eigene Erhebung

(Mehrfach-Antworten waren möglich) 


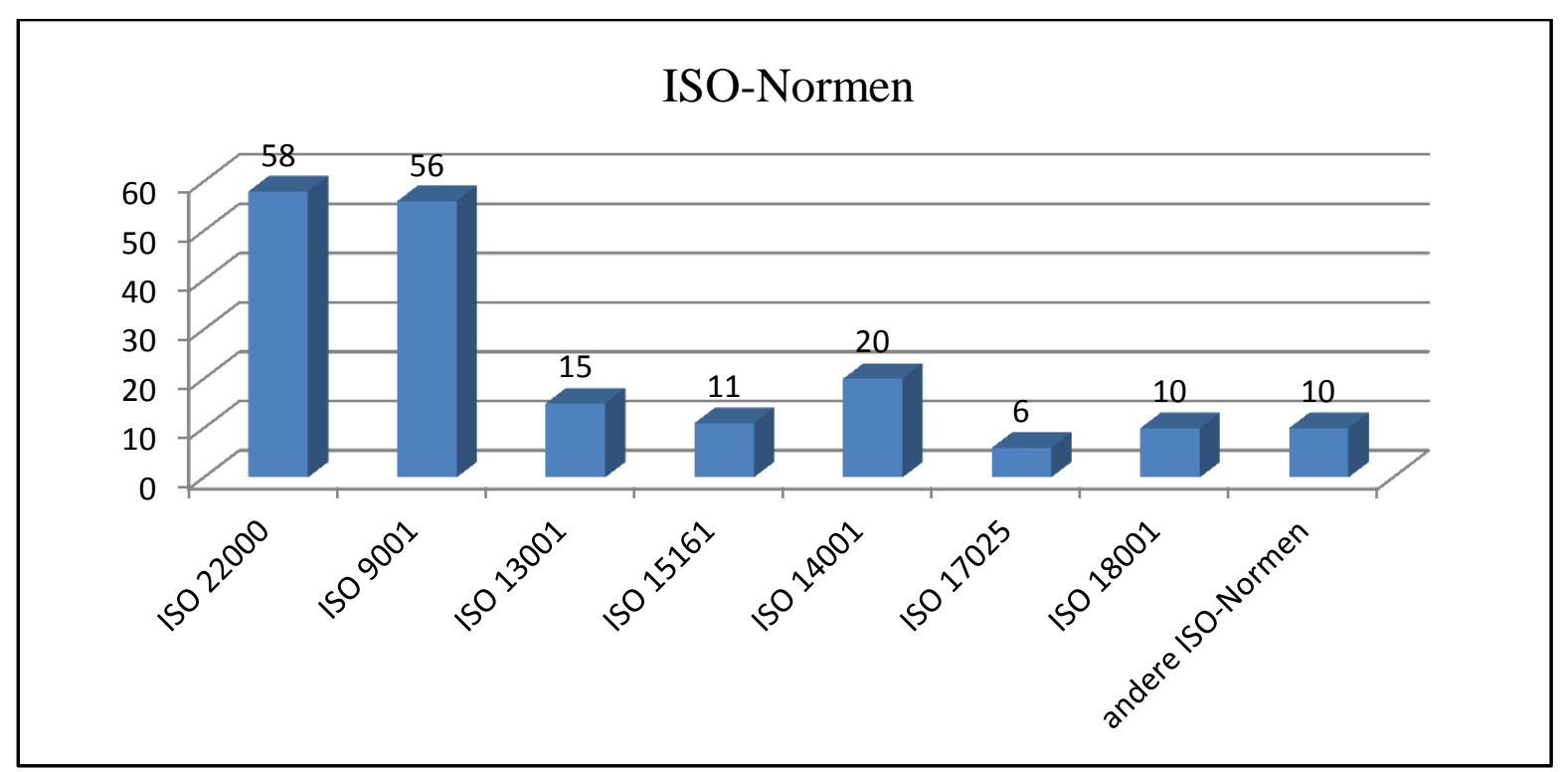

Quelle: Eigene Berechnungen

Verteilung der Zertifizierungssysteme in der türkischen Agrar- und Ernährungswirtschaft: 23 Unternehmen nutzen nur ein Zertifizierungssystem (ZS), 19 Unternehmen nutzen zwei ZS, 17 Unternehmen nutzen drei ZS, 15 Unternehmen vier ZS, 14 Unternehmen fünf ZS, zwölf Unternehmen sechs ZS, sechs Unternehmen sieben ZS und vier Unternehmen nutzen mehr als acht Zertifizierungssysteme. 
Verteilung der Zertifizierungssysteme(ZS) in der türkischen Agrar- und Ernährungswirtschaft

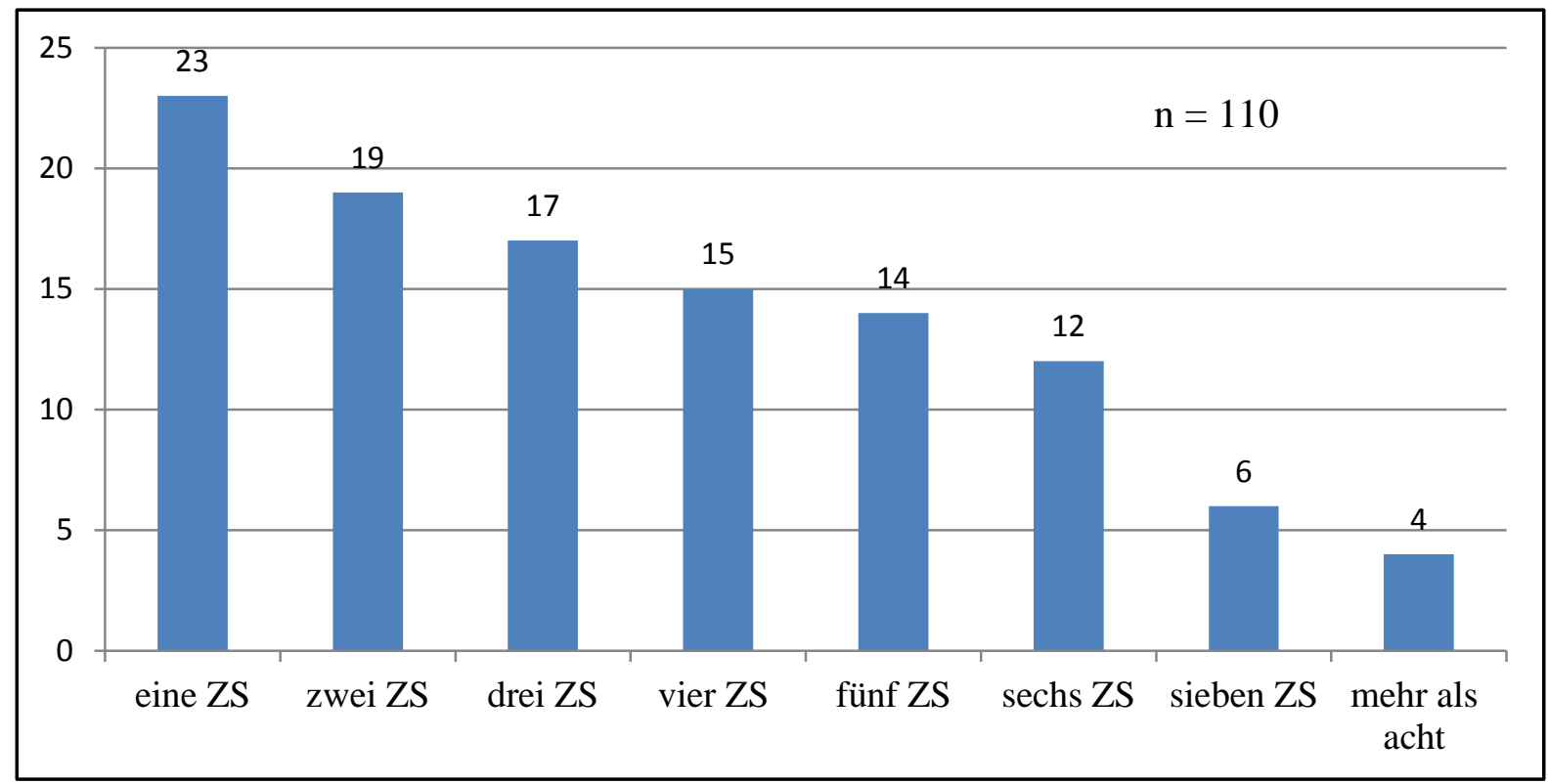

Quelle: Eigene Erhebung

Er wurde außerdem nach den drei wichtigsten Zertifizierungssystemen gefragt.

\section{Rangliste für Zertifizierungssysteme}

\begin{tabular}{|l|l|l|}
\hline $\begin{array}{l}\text { Primäres } \\
\text { Zertifizierungssystem }\end{array}$ & $\begin{array}{l}\text { Sekundäres } \\
\text { Zertifizierungssystem }\end{array}$ & $\begin{array}{l}\text { Tertiäres } \\
\text { Zertifizierungssystem }\end{array}$ \\
\hline ISO-Normen $(\mathrm{n}=51)$ & ISO-Normen $(\mathrm{n}=41)$ & ISO-Normen $(\mathrm{n}=20)$ \\
\hline türk. Leb.-Kodex $(\mathrm{n}=18)$ & Halal-Zert. $(\mathrm{n}=10)$ & Halal-Zert. $(\mathrm{n}=11)$ \\
\hline HACCP $(\mathrm{n}=17)$ & HACCP $(\mathrm{n}=9)$ & HACCP $(\mathrm{n}=10)$ \\
\hline Halal-Zert. $(\mathrm{n}=4)$ & türk. Leb.-Kodex $(\mathrm{n}=7)$ & türk. Leb.-Kodex $(\mathrm{n}=3)$ \\
\hline BRC $(\mathrm{n}=3)$ & CE $(\mathrm{n}=2)$ & PDO $(\mathrm{n}=1)$ \\
\hline FSSC $(\mathrm{n}=2)$ & TÜV Inter Cert $(\mathrm{n}=1)$ & IFS $(\mathrm{n}=1)$ \\
\hline Andere $(\mathrm{n}=7)$ & Andere $(\mathrm{n}=6)$ & Andere $(\mathrm{n}=6)$ \\
\hline Insgesamt $(\mathrm{n}=102)$ & Insgesamt $(\mathrm{n}=76)$ & Insgesamt $(\mathrm{n}=52)$ \\
\hline
\end{tabular}

Quelle: Eigene Erhebung

Mehr als die Hälfte der Befragten haben die Kosten-Nutzenrelation als primären Grund für die Zertifizierungsentscheidung angegeben. Von Relevanz kann auch der Druck der Importländer $(39,4 \%)$ sein. Andere Gründe sind weniger bedeutsam. 
Häufigkeiten ,Zertifizierungsgründe“

\begin{tabular}{|l|c|c|c|c|c|}
\hline & $\begin{array}{c}\text { trifft } \\
\text { über- } \\
\text { haupt } \\
\text { nicht zu }\end{array}$ & $\begin{array}{c}\text { trifft } \\
\text { weniger } \\
\text { zu }\end{array}$ & $\begin{array}{c}\text { teils/ } \\
\text { teils }\end{array}$ & $\begin{array}{c}\text { trifft } \\
\text { eher } \\
\text { zu }\end{array}$ & $\begin{array}{c}\text { trifft voll } \\
\text { und ganz } \\
\text { zu }\end{array}$ \\
\hline Kosten-Nutzenrelation $(n=92)$ & $4,3 \%$ & $13 \%$ & $29,3 \%$ & $42,4 \%$ & $10,9 \%$ \\
\hline $\begin{array}{l}\text { Bekanntheitsgrad der Zertifizierungsstelle } \\
(n=90)\end{array}$ & $10 \%$ & $30 \%$ & $24,4 \%$ & $30 \%$ & $5,6 \%$ \\
\hline Örtliche Nähe zum Zertifizierer $(n=92)$ & $8,7 \%$ & $30,4 \%$ & $27,2 \%$ & $27,2 \%$ & $6,5 \%$ \\
\hline $\begin{array}{l}\text { Auf Empfehlung des Handelsunterneh- } \\
\text { mens }(n=89)\end{array}$ & $13,5 \%$ & $24,7 \%$ & $34,8 \%$ & $24,7 \%$ & $2,2 \%$ \\
\hline Druck von Importländern $(n=94)$ & $9,6 \%$ & $23,4 \%$ & $27,7 \%$ & $30,9 \%$ & $8,5 \%$ \\
\hline Druck von Abnehmern $(n=91)$ & $7,7 \%$ & $26,4 \%$ & $36,3 \%$ & $22 \%$ & $7,7 \%$ \\
\hline $\begin{array}{l}\text { Es ist unbürokratischer als andere Syste- } \\
\text { me }(n=90)\end{array}$ & $11,1 \%$ & $28,9 \%$ & $36,7 \%$ & $20 \%$ & $3,3 \%$ \\
\hline $\begin{array}{l}\text { Effektiver (besserer Wirkungsgrad) als } \\
\text { andere Systeme }(n=95)\end{array}$ & $5,3 \%$ & $11,6 \%$ & $31,6 \%$ & $34,7 \%$ & $16,8 \%$ \\
\hline
\end{tabular}

Frage: Aus welchen Gründen haben Sie Ihr Zertifizierungssystem ausgewählt?

\section{Quelle: Eigene Erhebung}

Ausgewählte Ergebnisse zeigen, dass bei der Einführung des jeweiligen Zertifizierungssystems, besonders bei den Gerätekalibrierungen, den Labor- und Analysekosten, den Unternehmen in der Regel weitere Kosten entstehen. Ungefähr die Hälfte der Unternehmen müssen auch bei der externen Beratung Zusatzkosten einplanen.

\section{Zusatzkosten bei der Einführung des Zertifizierungssystems}

\begin{tabular}{|l|c|c|c|c|c|}
\hline & $\begin{array}{c}\text { trifft } \\
\text { ubberhaupt } \\
\text { nicht zu }\end{array}$ & $\begin{array}{c}\text { trifft } \\
\text { weniger } \\
\mathrm{zu}\end{array}$ & $\begin{array}{c}\text { teils/ } \\
\text { teils }\end{array}$ & $\begin{array}{c}\text { trifft } \\
\mathrm{eher} \\
\mathrm{zu}\end{array}$ & $\begin{array}{c}\text { trifft } \\
\text { voll und } \\
\mathrm{ganz} \mathrm{zu}\end{array}$ \\
\hline Mitarbeiterfortbildung $(n=92)$ & $6,5 \%$ & $14,1 \%$ & $20,7 \%$ & $52,2 \%$ & $6,5 \%$ \\
\hline Aufzeichnungspflichten $(n=92)$ & $6,5 \%$ & $12 \%$ & $25 \%$ & $50 \%$ & $6,5 \%$ \\
\hline Externe Beratung $(n=94)$ & $6,4 \%$ & $12,8 \%$ & $28,7 \%$ & $44,7 \%$ & $7,4 \%$ \\
\hline Neue technische Investitionen $(n=90)$ & $5,6 \%$ & $6,7 \%$ & $28,9 \%$ & $50 \%$ & $8,9 \%$ \\
\hline $\begin{array}{l}\text { Infrastruktur und Gebäuderenovierung } \\
(n=89)\end{array}$ & $9 \%$ & $15,7 \%$ & $23,6 \%$ & $38,2 \%$ & $13,5 \%$ \\
\hline Labor- und Analysekosten $(n=93)$ & $9,7 \%$ & $9,7 \%$ & $19,4 \%$ & $49,5 \%$ & $11,8 \%$ \\
\hline Gerätekalibrierungen $(n=93)$ & $7,5 \%$ & $5,4 \%$ & $24,7 \%$ & $52,7 \%$ & $9,7 \%$ \\
\hline vorbeugende Instandhaltung $(n=90)$ & $6,7 \%$ & $5,6 \%$ & $32,2 \%$ & $45,6 \%$ & $10 \%$ \\
\hline $\begin{array}{l}\text { Frage: } \text { Sind für die folgenden Bereiche zusätzliche Kosten bei der Einführung des } \\
\text { Zertifizierungssystems entstanden? }\end{array}$ &
\end{tabular}

Quelle: Eigene Erhebung 
In der folgenden Tabelle wiedergegebene Frage (Häufigkeiten der Wettbewerbsstrategien) haben sich die Unternehmen besonders stark beteiligt. Knapp $84 \%$ der Unternehmen finden es wichtig, innovatives Marketing zu betreiben, günstig einzukaufen und die Effizienz der Arbeitsprozesse sicherzustellen. Interessant ist dabei, dass die Frage nach der Kostenführerschaft im internationalen Wettbewerb nur für $54 \%$ der Unternehmen relevant ist.

\section{Häufigkeiten der Wettbewerbsstrategien}

\begin{tabular}{|l|c|c|c|c|c|}
\hline & $\begin{array}{c}\text { gar nicht } \\
\text { wichtig }\end{array}$ & $\begin{array}{c}\text { weniger } \\
\text { wichtig }\end{array}$ & $\begin{array}{c}\text { teils/ } \\
\text { teils }\end{array}$ & $\begin{array}{c}\text { eher } \\
\text { wichtig }\end{array}$ & $\begin{array}{c}\text { sehr } \\
\text { wichtig }\end{array}$ \\
\hline Effizienz der Arbeitsprozesse sicherstellen $(n=96)$ & $2,1 \%$ & $4,2 \%$ & $13,5 \%$ & $69,8 \%$ & $10,4 \%$ \\
\hline Günstig einkaufen (Beschaffung) $(n=92)$ & $1,1 \%$ & $4,3 \%$ & $13 \%$ & $53,3 \%$ & $28,3 \%$ \\
\hline Innovatives Marketing betreiben $(n=96)$ & $3,1 \%$ & $4,2 \%$ & $9,4 \%$ & $53,1 \%$ & $30,2 \%$ \\
\hline Niedrige Preise anbieten $(n=92)$ & $8,7 \%$ & $7,6 \%$ & $29,3 \%$ & $41,3 \%$ & $13 \%$ \\
\hline $\begin{array}{l}\text { Marken- und Firmenreputation kommunizieren } \\
(n=92)\end{array}$ & $2,2 \%$ & $10,9 \%$ & $16,3 \%$ & $52,2 \%$ & $18,5 \%$ \\
\hline $\begin{array}{l}\text { Strebe Kostenführerschaft an, um im internationa- } \\
\text { len Wettbewerb zu bestehen }(n=95)\end{array}$ & $6,3 \%$ & $8,4 \%$ & $31,6 \%$ & $46,3 \%$ & $7,4 \%$ \\
\hline $\begin{array}{l}\text { Wir setzen im internationalen Wettbewerb auf } \\
\text { Qualitäts- und Innovationsführerschaft }(n=94)\end{array}$ & $4,3 \%$ & $4,3 \%$ & $31,9 \%$ & $47,9 \%$ & $11,7 \%$ \\
\hline $\begin{array}{l}\text { Im internationalen Wettbewerb bedienen wir ge- } \\
\text { zielt Nischen }(n=90)\end{array}$ & $5,6 \%$ & $3,3 \%$ & $25,6 \%$ & $51,1 \%$ & $14,4 \%$ \\
\hline $\begin{array}{l}\text { Wir sind meistens vor unseren Mitbewerbern mit } \\
\text { neuen Produkten auf dem Markt }(n=95)\end{array}$ & $3,2 \%$ & $10,5 \%$ & $25,3 \%$ & $36,8 \%$ & $24,2 \%$ \\
\hline
\end{tabular}

Frage: Wie wichtig sind die folgenden Aktivitäten für das Gelingen Ihrer Wettbewerbsstrategie?

\section{Quelle: Eigene Erhebung}


In der nachfolgenden Tabelle werden die Häufigkeiten für verschiedene Aspekte der unternehmerischen Verantwortung dargestellt. Die ausgewählten Ergebnisse zeigen, dass die beteiligten Unternehmen ihre unternehmerische Verantwortung sehr ernst nehmen. Beim Umweltbewusstsein fällt erfreulicherweise auf, dass viele Unternehmen diesen Faktor (72\%) als wichtig oder sogar sehr wichtig einschätzen.

Häufigkeiten ,unternehmerische Verantwortung“6

\begin{tabular}{|l|c|c|c|c|c|}
\hline & $\begin{array}{c}\text { lehne } \\
\text { voll und } \\
\text { ganz ab }\end{array}$ & $\begin{array}{c}\text { lehne } \\
\text { ab }\end{array}$ & $\begin{array}{c}\text { teils/ } \\
\text { teils }\end{array}$ & $\begin{array}{c}\text { stim- } \\
\text { me zu }\end{array}$ & $\begin{array}{c}\text { stimme } \\
\text { voll und } \\
\text { ganz zu }\end{array}$ \\
\hline $\begin{array}{l}\text { Unternehmerische Verantwortung ist Teil unserer } \\
\text { Marketingstrategie }(n=98)\end{array}$ & $2 \%$ & $8,2 \%$ & $12,2 \%$ & $59,2 \%$ & $18,4 \%$ \\
\hline $\begin{array}{l}\text { Die Zertifizierung zur Wahrnehmung unter- } \\
\text { nehmerischer Verantwortung, halte ich für } \\
\text { sinnvoll }(n=97)\end{array}$ & $4,1 \%$ & $5,2 \%$ & $15,5 \%$ & $58,8 \%$ & $16,5 \%$ \\
\hline $\begin{array}{l}\text { Unsere Lieferanten und Abnehmer schätzen } \\
\text { besonders die faire Zusammenarbeit mit unserem } \\
\text { Unternehmen }(n=96)\end{array}$ & $1 \%$ & $5,2 \%$ & $13,5 \%$ & $50 \%$ & $30,2 \%$ \\
\hline Für faires Verhalten sind wir allgemein bekannt & $1,1 \%$ & $5,5 \%$ & $16,5 \%$ & $47,3 \%$ & $29,7 \%$ \\
\hline $\begin{array}{l}\text { Zu Partnern aus dem lokalen/regionalen Umfeld } \\
\text { haben wir besonders enge Geschäftsbeziehungen } \\
(n=92)\end{array}$ & $3,3 \%$ & $8,7 \%$ & $12 \%$ & $58,7 \%$ & $17,4 \%$ \\
\hline $\begin{array}{l}\text { Unser Unternehmen gilt als ausgesprochen } \\
\text { umweltbewusst }(n=93)\end{array}$ & $4,3 \%$ & $7,5 \%$ & $16,1 \%$ & $50,5 \%$ & $21,5 \%$ \\
\hline
\end{tabular}

Frage: Wie geht Ihr Unternehmen mit dem Thema unternehmerische Verantwortung um?

Quelle: Eigene Erhebung 


\section{Fragebogen zum Konsumverhalten von Muslimen in Deutschland bei Halal Lebensmitteln: Fallbeispiel Göttingen}

Sehr geehrte Verbraucher, diese Umfrage wird in Zusammenarbeit mit der Kahramanmaras Sutcu Imam Universität und der Universität Göttingen durchgeführt. Das Thema ist ,Das Konsumverhalten von Muslimen in Deutschland zu Halal Lebensmitteln: Fallbeispiel Göttingen'. Ihre Antworten auf den Fragebogen werden erheblich dazu beitragen, den Zweck dieser Studie zu erreichen. Vielen Dank für Ihre Mitarbeit.

\begin{tabular}{|c|c|}
\hline 1. Umfrage Nr. & c1. \\
\hline 2. Wie alt sind Sie? & c2. \\
\hline 3. Geschlecht? $\quad$ 1> Männlich, $\quad 0>$ Weiblich & $\mathrm{c} 3$. \\
\hline 4. Familienstand? $\quad$ 1> Verheiratet $\quad$ 2> Single $\quad 3>$ Geschieden $\quad$ 4>Verwitwet & $c 4$. \\
\hline 5. Wenn Sie verheiratet sind, arbeitet Ihr Ehepartner? $\quad$ 1> Ja, $0>$ Nein & c5. \\
\hline 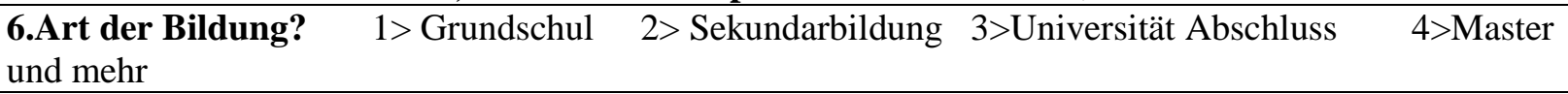 & $\mathrm{c6.}$ \\
\hline 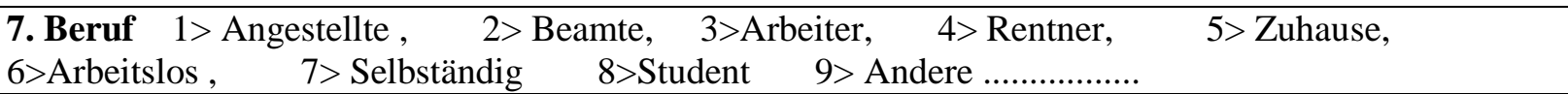 & c7. \\
\hline 8. Herkunftsland? & $c 8$. \\
\hline 9. Seit wie viele Jahren leben Sie in Deutschland? & $\mathrm{c} 9$. \\
\hline 10. Wie gut sprechen Sie Deutsch? $1>$ Sehr Gut, 2> Gut, 3> Mittelmaß, 4> Schlecht, 5> Gar nicht & $\mathrm{c} 10$. \\
\hline $\begin{array}{l}\text { 11. Wer macht oft den Einkauf von Lebensmitteln in Ihrer Familie? } 1>\text { Nur ich, } 2>\text { überwiegend ich } \\
3>\text { teils teils, } 4>\text { überwiegend jemand } 5>\text { jemand anders }\end{array}$ & $\mathrm{c} 11$. \\
\hline 12. Wie viele Personen leben in ihrem Haushalt? & $\mathrm{c} 12$. \\
\hline 13. Haushaltnettoeinkommen ? €,EUR & $\mathrm{c} 13$. \\
\hline $\begin{array}{l}\text { 14. Wie viel von Ihrem Einkommen geben Sie monatlich für folgende Dinge im Durchschnitt aus? } \\
€, E U R\end{array}$ & c14. \\
\hline Kleidung & $\mathrm{c} 15$. \\
\hline Lebensmittel & $\mathrm{c} 16$. \\
\hline Bildung & $\mathrm{c} 17$. \\
\hline Miete & $\mathrm{c} 18$. \\
\hline Kommunikation & $\mathrm{c} 19$. \\
\hline Unterhaltung /Reise & $\mathrm{c} 20$. \\
\hline Transport & $\mathrm{c} 21$. \\
\hline Gesundheit & $\mathrm{c} 22$. \\
\hline Sonstige .................. & $\mathrm{c} 23$. \\
\hline $\begin{array}{l}\text { 15. Wie erhalten Sie oft die folgenden Lebensmittel? } \\
\text { 1> Immer unverpackt-unbeschriftet, } 2>\text { sehr wenig verpackte - beschriftet } 3>\text { Mittelmäßig verpackte - } \\
\text { beschriftet, } 4>\text { Oft verpackte - beschriftet, 5>Immer verpackte - beschriftet, }\end{array}$ & \\
\hline Rotes Fleisch & c24. \\
\hline Weißes Fleisch & $\mathrm{c} 25$. \\
\hline Wurst, Salami & $\mathrm{c} 26$. \\
\hline Joghurt & $\mathrm{c} 27$. \\
\hline Getränke & $\mathrm{c} 28$. \\
\hline Käse & $\mathrm{c} 29$. \\
\hline Backwaren & $\mathrm{c} 30$. \\
\hline Eis & $\mathrm{c} 31$. \\
\hline Süßwaren & $\mathrm{c} 32$. \\
\hline
\end{tabular}




\begin{tabular}{|c|c|c|c|c|c|c|c|c|c|c|}
\hline \multicolumn{10}{|c|}{$\begin{array}{l}\text { 16. Woher kaufen Sie die Lebensmittel? } \\
\text { 1> Kaufe gar nicht, 2>Kaufe sehr wenig } 3\end{array}$} & \multirow[b]{2}{*}{ Döner } \\
\hline & $\begin{array}{l}\text { Rotes } \\
\text { Fleisch }\end{array}$ & $\begin{array}{l}\text { Weißes } \\
\text { Fleisch }\end{array}$ & $\begin{array}{l}\text { Wurst } \\
\text { Salami }\end{array}$ & Joghurt & Getränke & Käse & Backwaren & Eis & $\begin{array}{l}\text { Süßware } \\
n\end{array}$ & \\
\hline $\begin{array}{l}\text { Muslimisches } \\
\text { Geschäft }\end{array}$ & c33. & c34. & $\mathrm{c} 35$ & c36. & $\mathrm{c} 37$. & c38. & c39. & c40. & c41. & $\mathrm{c} 42$. \\
\hline Markplatz & c43. & c44. & $c 45$. & c 46. & c47. & c48. & c49. & c50. & c51. & $\mathrm{c} 52$. \\
\hline $\begin{array}{l}\text { Lebensmittel } \\
\text { geschäft }\end{array}$ & $c 53$. & c54. & $\mathrm{c55}$. & $c 56$. & c57. & $\mathrm{c} 58$. & c59. & $c 60$. & $\mathrm{c} 61$. & $\mathrm{c} 62$. \\
\hline Supermarkt & c63. & c64. & c65. & $\mathrm{c} 66$. & $\mathrm{c} 67$. & c68. & c69. & c70. & c71. & c72. \\
\hline Hersteller & $\mathrm{c} 73$. & c74. & $\mathrm{c75}$. & c76. & $\mathrm{c} 77$. & c78. & c79. & $\mathrm{c} 80$. & $\mathrm{c} 81$. & $\mathrm{c} 82$. \\
\hline Sonstige & $\mathrm{c} 83$. & c84. & $\mathrm{c} 85$. & $\mathrm{c} 86$. & c87. & $\mathrm{c} 88$. & $\mathrm{c} 89$. & $\mathrm{c} 90$. & $\mathrm{c} 91$. & $\mathrm{c} 92$. \\
\hline
\end{tabular}

\begin{tabular}{|c|c|}
\hline 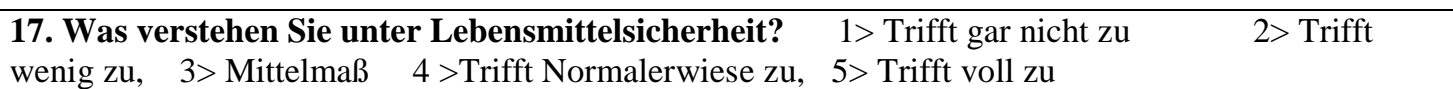 & \\
\hline Gesunde Lebensmittel & c93. \\
\hline Zutaten bekannte Lebensmittel & c94. \\
\hline Mindesthaltbarkeitsdatum nicht überschritten & $\mathrm{c} 95$. \\
\hline Zusatzstoff-freie Lebensmittel & c96. \\
\hline Lebensmittel die ein Qualitätszertifikat haben & c97. \\
\hline Markenartikel Lebensmittel & c98. \\
\hline Halal Lebensmittel & c99. \\
\hline Verpackte und beschriftete Lebensmittel & $\mathrm{c} 100$. \\
\hline $\begin{array}{l}\text { 18. Was verstehen Sie unter 'nicht sicheren Lebensmitteln'? } 1>\text { Trifft gar nicht zu, } 2>\text { Trifft } \\
\text { wenig zu, } 3>\text { Mittelmaß } \quad 4>\text { Trifft Normalerwiese zu, 5> Trifft voll zu }\end{array}$ & \\
\hline Hormonhaltige Lebensmittel & c101. \\
\hline Pestizid- haltige Lebensmittel & $\mathrm{c} 102$. \\
\hline Gentechnisch veränderte Lebensmittel & $\mathrm{c} 103$. \\
\hline Lebensmittel die Zusatzstoff enthalten & $\mathrm{c} 104$. \\
\hline Lebensmittel die tierische Krankheiten enthalten (BSE, Vogelgrippe) & $\mathrm{c} 105$. \\
\hline Lebensmittel deren Mindesthaltbarkeitsdatum überschritten ist & c106. \\
\hline Lebensmittel die unbeschriftet sind & $\mathrm{c} 107$. \\
\hline Lebensmittel die nicht Halal sind & $\mathrm{c} 108$. \\
\hline 19. Welche der folgenden Zertifizierungen kennen Sie? & \\
\hline HACCP $1>\mathrm{Ja}, 0>$ Nein & $\mathrm{c} 109$. \\
\hline 1> Ja, $0>$ Nein & $\mathrm{c} 110$. \\
\hline $1>\mathrm{Ja}, 0>\mathrm{Nein}$ & c111. \\
\hline $1>\mathrm{Ja}, 0>$ Nein & $\mathrm{c} 112$. \\
\hline BIO / ökologische Lebensmittel & c113. \\
\hline Lebensmittel mit geografischen Angabe & $\mathrm{c} 114$. \\
\hline Halal Lebensmittel $1>\mathrm{Ja}, 0>$ Nein & c115. \\
\hline 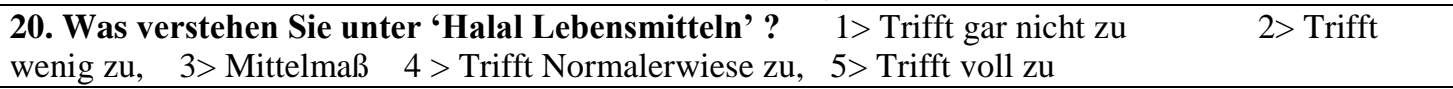 & \\
\hline Bedeutet, dass das Produkt Schweinefleisch nicht enthalt & $\mathrm{c} 116$. \\
\hline Bedeutet, dass das Produkt Alkohol nicht enthalt & c117. \\
\hline Bedeutet, dass das Produkt von muslimischen Menschen produziert ist & c118. \\
\hline Bedeutet, dass das Produkt nach islamischen Regeln hergestellt ist & c119. \\
\hline Bedeutet, dass das Produkt gesund ist. & $\mathrm{c} 120$. \\
\hline Bedeutet, dass das Produkt köstlicher ist & $\mathrm{c} 121$. \\
\hline Bedeutet, dass das Produkt preislich teurer ist. & $\mathrm{c} 122$. \\
\hline $\begin{array}{l}\text { Halal Lebensmittel bedeutet; die pflanzlichen, tierischen, chemischen oder mikrobiellen Ursprünge } \\
\text { von Lebensmitteln; Rohstoffe, jegliche Hilfskomponenten, Zusatzstoffe, Verarbeitungsverfahren, } \\
\text { Betriebsbedingungen und Verpackung; bei all diesen Komponenten und Schritten die islamischen } \\
\text { Regeln eingehalten werden. }\end{array}$ & \\
\hline
\end{tabular}




\begin{tabular}{|c|c|c|c|c|c|}
\hline \multicolumn{5}{|c|}{$\begin{array}{lllll}\text { Bewerten Sie die Fragen 21-30: 1> Trifft gar nicht zu } & \text { 2> Trifft wenig zu, } & 3>\text { Mittelmaß } & 4> \\
\text { Trifft Normalerwiese zu, 5> Trifft voll zu } & & \\
\end{array}$} & \\
\hline \multicolumn{5}{|c|}{ 21. Achten Sie darauf, ob das von Ihnen gekaufte Produkt halal ist? } & c123. \\
\hline \multicolumn{5}{|c|}{ 22. Wissen Sie, dass in Süßwaren Schweinegelatine enthalten sein kann? } & $\mathrm{c} 124$. \\
\hline \multicolumn{5}{|c|}{ 23. Wissen Sie, dass Käse-Hefe aus Schwein hergestellt werden kann? } & c125. \\
\hline \multicolumn{5}{|c|}{ 24. Wissen Sie, dass kohlensäurehaltige Getränke $0,5 \%$, Alkohol enthalten können? } & c126. \\
\hline \multicolumn{5}{|c|}{ 25. Wissen Sie, dass Brot und Kuchen Schweinefett enthalten kann? } & $\mathrm{c} 127$. \\
\hline \multicolumn{5}{|c|}{ 26. Haben Sie schon von Halal-Lebensmittel-Zertifizierung gehört? } & $\mathrm{c} 128$. \\
\hline \multicolumn{6}{|c|}{ 27. Wenn ja, was ist Halal-Lebensmittel-Zertifizierung? } \\
\hline \multicolumn{5}{|c|}{ Produziert in Übereinstimmung mit der Religion } & c129. \\
\hline \multicolumn{5}{|c|}{ Die Einhaltung von Gesundheit und Qualität bei der Produktion } & $\mathrm{c} 130$. \\
\hline \multicolumn{5}{|c|}{ Halal Garantie des Produktes } & c131. \\
\hline \multicolumn{5}{|c|}{ Dem Lebensmittel kann man vertrauen } & $\mathrm{c} 132$. \\
\hline \multicolumn{5}{|c|}{ Pur, Naturprodukt } & $\mathrm{c} 133$. \\
\hline \multicolumn{5}{|c|}{ 28. Achten Sie beim Kauf von Lebensmitteln darauf, dass es ein Halal-Zertifikat hat? } & c134. \\
\hline \multicolumn{5}{|c|}{ 29. Ich achte darauf, ob das Lebensmittel ein Halal-Zertifikat hat, weil } & \\
\hline \multicolumn{5}{|c|}{ Aus religiösen Gründen } & $\mathrm{c} 135$. \\
\hline \multicolumn{5}{|c|}{ Viel zuverlässiger } & $\mathrm{c} 136$. \\
\hline \multicolumn{5}{|c|}{ Viel gesünder } & c137. \\
\hline \multicolumn{5}{|c|}{ Viel schmackhafter } & c138. \\
\hline \multicolumn{5}{|c|}{ Bessere Qualität } & c139. \\
\hline \multicolumn{6}{|c|}{ 30. Ich verbrauche keine Lebensmittel mit Halal-Zertifikaten, weil... } \\
\hline \multicolumn{5}{|c|}{ Davon nicht gehört } & $\mathrm{c} 140$. \\
\hline Zu teuer & & & & & $\mathrm{c} 141$. \\
\hline Ich kann Halal-2 & rtifikat Lebensm & 1 nicht finden & & & $\mathrm{c} 142$. \\
\hline Ich traue dem Z & ifikat nicht & & & & c143. \\
\hline Es schmeckt mi & icht & & & & c144. \\
\hline Ich glaube alles & halal & & & & $\mathrm{c} 145$. \\
\hline $\begin{array}{l}\text { 31. Haben Sie zu } \\
\text { 1> Nein, ich tat es } \\
\text { 4> Gelegentlich } k\end{array}$ & $\begin{array}{l}\text { r eine Halal-Zer } \\
\text { icht, 2> Ich kau } \\
\text { fe ich es, 5> Ich }\end{array}$ & $\begin{array}{l}\text { at Lebensmitte } \\
\text { s ein paar Mal, } \\
\text { ufe nur halal-zer }\end{array}$ & $\begin{array}{l}\text { kauft? } \\
\text { Manchmal kauf } \\
\text { ierte Lebensmitte }\end{array}$ & & c146. \\
\hline $\begin{array}{l}\text { 32. Welche Prod } \\
\text { Möchte ein wenig }\end{array}$ & $\begin{array}{l}\text { ste möchten Sie } \\
\text { 3> Möchte mitte }\end{array}$ & $\begin{array}{l}\text { Halal-Zertifiks } \\
\text { Big, > } 4 \text { Möcht }\end{array}$ & $\begin{array}{l}\text { aben. ..... 1> Mö } \\
\text { rmalerwiese, } 5\end{array}$ & $\begin{array}{l}\text { keinen Fall 2> } \\
\text { e auf jeden Fall }\end{array}$ & \\
\hline Rotes Fleisch & & & & & c147. \\
\hline Weißes Fleisch & & & & & c148. \\
\hline Wurst, Salami & & & & & $\mathrm{c} 149$. \\
\hline Joghurt & & & & & $\mathrm{c} 150$. \\
\hline Getränke & & & & & c151. \\
\hline Käse & & & & & $\mathrm{c} 152$. \\
\hline Backwaren & & & & & $\mathrm{c} 153$. \\
\hline Eis & & & & & $\mathrm{c} 154$. \\
\hline Süßwaren & & & & & $\mathrm{cc155.}$ \\
\hline Döner & & & & & $\mathrm{c} 156$. \\
\hline 33. Bitte geben $S$ & an in welcher $M$ & e Sie pro Mona & gende Lebensm & brauchen & \\
\hline Lebensmittel & Ohne & al-Zertifikat & Mit Hala & fikat & \\
\hline & $\mathrm{Kg} / \mathrm{Anzahl} / \mathrm{lt}$ & $€$, EUR & $\mathrm{Kg} / \mathrm{Anzahl} / \mathrm{lt}$ & $€, \mathrm{EUR}$ & \\
\hline Rotes Fleisch & c157. & c158. & $\mathrm{c} 159$ & c160. & \\
\hline Weißes Fleisch & c161. & c162. & c163. & c164. & \\
\hline Wurst, Salami & $\mathrm{c} 165$. & c166. & c167. & c168. & \\
\hline Joghurt & c169. & c170. & $\mathrm{c} 171$. & c172. & \\
\hline Getränke & $\mathrm{c} 173$. & c174. & $\mathrm{c} 175$. & c176. & \\
\hline Käse & $\mathrm{c} 177$. & c178. & c179. & c180. & \\
\hline Backwaren & $\mathrm{c} 181$. & c182. & $\mathrm{c} 183$. & c184. & \\
\hline
\end{tabular}




\begin{tabular}{|c|c|c|c|c|c|}
\hline Eis & c185. & c186. & c187. & \multicolumn{2}{|l|}{ c188. } \\
\hline Süßwaren & c189. & c190. & c191. & \multicolumn{2}{|l|}{ c192. } \\
\hline Döner & c193. & c194. & c195. & \multicolumn{2}{|l|}{ c196. } \\
\hline \multicolumn{5}{|c|}{ 34. Wie viel würden Sie mehr bezahlen, im Falle eines Halal-Zertifikat-Produktes (\%)? } & \\
\hline \multicolumn{5}{|c|}{ Rotes Fleisch } & c197. \\
\hline \multicolumn{5}{|c|}{ Weißes Fleisch } & c198. \\
\hline \multicolumn{5}{|c|}{ Wurst, Salami } & c199. \\
\hline \multicolumn{5}{|c|}{ Joghurt } & $\mathrm{c} 200$. \\
\hline \multicolumn{5}{|l|}{ Getränke } & c201. \\
\hline \multicolumn{5}{|l|}{ Käse } & $\mathrm{c} 202$. \\
\hline \multicolumn{5}{|l|}{ Backwaren } & $\mathrm{c} 203$. \\
\hline \multicolumn{5}{|l|}{ Eis } & $\mathrm{c} 204$. \\
\hline \multicolumn{5}{|l|}{ Süßwaren } & $\mathrm{c} 205$. \\
\hline \multicolumn{5}{|c|}{ Döner } & c206. \\
\hline \multicolumn{5}{|c|}{ 35. Ihre Empfehlungen für Halal-Lebensmittel Zertifikat? } & $\mathrm{c} 207$. \\
\hline
\end{tabular}


Değerli tüketici; bu anket, Göttingen Üniversitesi ile Kahramanmaraş Sütçü İmam Üniversitesi işbirliğinde, 'Almanya'da Helal Gıda Konusunda Müslüman Tüketicilerin Davranışları; Göttingen Örneği' başlıklı araştırma için yapılmaktadır. Ankete vereceğiniz cevapların sağlıklı ve tutarlı olması bu çalışmanın amacına ulaşmasına büyük ölçüde yardımcı olacaktır. Katkılarınızdan dolayı teşekkür ederiz.

\begin{tabular}{|c|c|}
\hline 1. Anket No & c208. \\
\hline 2.Yașınız? & $\mathrm{c} 209$. \\
\hline 3.Cinsiyetiniz? $\quad 1>$ Erkek, $\quad 0>$ Kadın & c210. \\
\hline 4.Medeni Durumunuz? $\quad$ 1>Evli $\quad$ 2>Bekar $\quad 3>$ Boşanmış & $\mathrm{c} 211$. \\
\hline 5. Evli iseniz eşiniz çalışıyor mu? $\quad$ 1> Evet, $\quad$ 2> Hayır & $\mathrm{c} 212$. \\
\hline 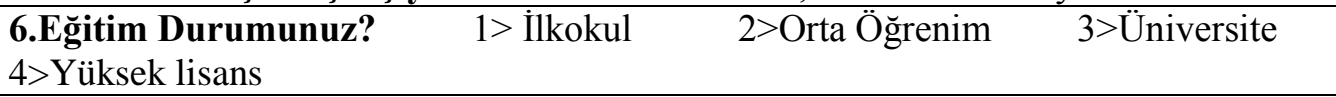 & $\mathrm{c} 213$. \\
\hline 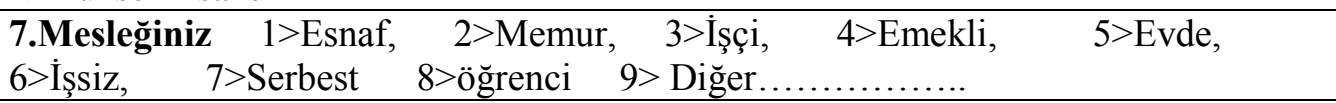 & $\mathrm{c} 214$. \\
\hline 8.Geldiğiniz ülke? & c215. \\
\hline 9. Kaç yıldır Almanya'da bulunuyorsunuz? & $\mathrm{c} 216$. \\
\hline $\begin{array}{l}\text { 10. Almanca konuşmanız nasıl? } \quad 1>\text { Pekiyi, } \quad 2>\text { İyi, } \quad 3>\text { Orta, } \quad 4>\text { Yetersiz, } \\
5>\text { Zayıf }\end{array}$ & $\mathrm{c} 217$. \\
\hline 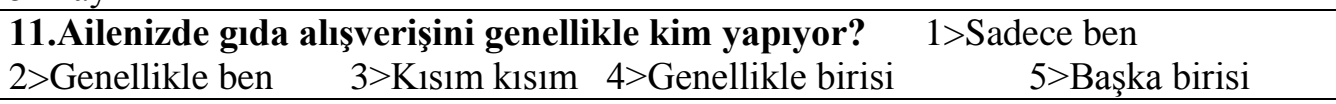 & c218. \\
\hline 12. Ailedeki birey sayısı & c219. \\
\hline 13.Aylık Geliriniz? & $\mathrm{c} 220$. \\
\hline 14. Aylık gelirinizin ne kadarını aşağıdaki harcama kalemlerine ayırıyorsunuz? & $\mathrm{c} 221$. \\
\hline Giyim & $\mathrm{c} 222$. \\
\hline Gida & c223. \\
\hline Eğitim & $\mathrm{c} 224$. \\
\hline Kira & c225. \\
\hline İletişim & $\mathrm{c} 226$. \\
\hline Eğlence/Gezi & c227. \\
\hline Ulaşım & c228. \\
\hline Sağlik & c229. \\
\hline Diğer............... & $\mathrm{c} 230$. \\
\hline $\begin{array}{l}\text { 15. Aşağıdaki gidaları çoğunlukla nasıl alırsınız? } 1>\text { Her zaman ambalajsız-etiketsiz } \\
2>\text { Çok az ambalajl1-etiketli } 3>\text { Orta düzeyde ambalajl1-etiketli, } \quad 4>\text { Genellikle } \\
\text { ambalajl1-etiketli, } \quad 5>\text { Her zaman ambalajl1-etiketli }\end{array}$ & \\
\hline Kirmizi et & c231. \\
\hline Beyaz et & $\mathrm{c} 232$. \\
\hline Sucuk, Salam, Sosis & c233. \\
\hline Yoğurt & $\mathrm{c} 234$. \\
\hline İçecek & $\mathrm{c} 235$. \\
\hline Peynir & c236. \\
\hline Unlu Mamuller & c237. \\
\hline Dondurma & $\mathrm{c} 238$. \\
\hline Şekerleme & c239. \\
\hline
\end{tabular}




\begin{tabular}{|c|c|c|c|c|c|c|c|c|c|c|}
\hline \multicolumn{10}{|c|}{ 16. Gıda alışverişinizi nereden yaptığınıza ilişkin bilgiler } & \multirow[b]{3}{*}{$\begin{array}{l}\text { Restoran } \\
\text { Döner }\end{array}$} \\
\hline \multicolumn{10}{|c|}{$\begin{array}{l}1>\text { Kesinlikle almam, } 2>\text { Çok az alırım } 3>\text { Orta alırım, } \quad 4>\text { Genellikle alırım, } \quad 5>\text { Her } \\
\text { zaman alırım }\end{array}$} & \\
\hline & \begin{tabular}{|l|} 
Kirmiz1 \\
et
\end{tabular} & $\begin{array}{l}\text { Beyaz } \\
\text { et }\end{array}$ & $\begin{array}{l}\text { Sucuk } \\
\text { Salam } \\
\text { Sosis }\end{array}$ & Yoğurt & İçecek & Peynir & $\begin{array}{l}\text { Unlu } \\
\text { Mamul }\end{array}$ & $\begin{array}{l}\text { Dondurm } \\
\text { a }\end{array}$ & Şekerleme & \\
\hline $\begin{array}{l}\text { Müslüman } \\
\text { Bakkal }\end{array}$ & $\mathrm{c} 240$ & $\mathrm{c} 241$. & $\mathrm{c} 242$. & $\mathrm{c} 243$. & c244. & $\mathrm{c} 245$ & $\mathrm{c} 246$. & c247. & c248. & c249. \\
\hline $\begin{array}{l}\text { Semt } \\
\text { pazarı }\end{array}$ & $\mathrm{c} 250$. & $\mathrm{c} 251$. & $\mathrm{c} 252$. & $\mathrm{c} 253$. & $\mathrm{c} 254$. & $\mathrm{c} 255$. & $\mathrm{c} 256$. & $\mathrm{c} 257$. & $\mathrm{c} 258$. & $\mathrm{c} 259$. \\
\hline Bakkal & $\mathrm{c} 260$. & c261. & $\mathrm{c} 262$. & c263. & c264. & $\mathrm{c} 265$. & $\mathrm{c} 266$. & $\mathrm{c} 267$. & c268. & c269. \\
\hline $\begin{array}{l}\text { Süpermar } \\
\text { ket }\end{array}$ & c270. & $\mathrm{c} 271$. & $\mathrm{c} 272$. & c273. & c274. & c275. & c276. & $\mathrm{c} 277$. & c278. & c279. \\
\hline Üreticiden & c280. & c281. & $\mathrm{c} 282$. & c283. & c284. & c285. & $\mathrm{c} 286$. & $\mathrm{c} 287$. & c288. & c289. \\
\hline Diğer & $\mathrm{c} 290$. & $\mathrm{c} 291$. & c292. & $\mathrm{c} 293$. & $\mathrm{c} 294$. & $\mathrm{c} 295$. & c296. & c297. & c298. & $\mathrm{c} 299$. \\
\hline \multicolumn{11}{|c|}{$\begin{array}{l}\text { 17. Gıda güvenliği, denildiğinde ne anlıyorsunuz? } \\
\text { Az Katılmıyorum, } 3>\text { Orta } 4>\text { Kesinlikle kat1lmiyorum } 2> \\
5>\text { Gesinlikle katılıyorum }\end{array}$} \\
\hline \multicolumn{10}{|c|}{ Sağlıklı gida } & $\mathrm{c} 300$. \\
\hline \multicolumn{10}{|c|}{ İceriği bilinen g1da } & $\mathrm{c} 301$. \\
\hline \multicolumn{10}{|c|}{ Son kullanma tarihi geçmemiș gida } & $\mathrm{c} 302$. \\
\hline \multicolumn{10}{|c|}{ Katkı maddesi içermeyen gida } & $\mathrm{c} 303$. \\
\hline \multicolumn{10}{|c|}{ Kalite belgesi olan gida } & c304. \\
\hline \multicolumn{10}{|c|}{ Markalı gida } & $\mathrm{c} 305$. \\
\hline \multicolumn{10}{|c|}{ Helal gida } & c306. \\
\hline \multicolumn{10}{|c|}{ Ambalajlı ve etiketli gida } & $\mathrm{c} 307$. \\
\hline \multicolumn{11}{|c|}{ 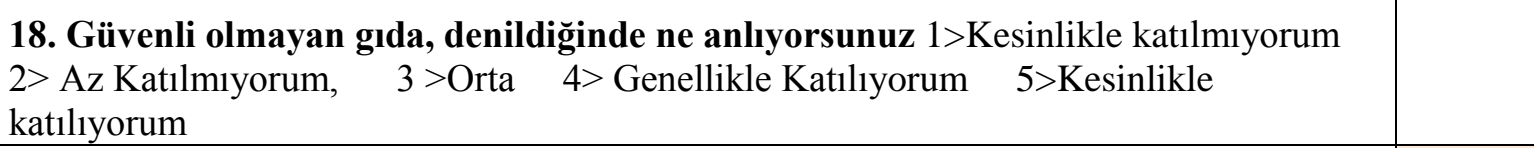 } \\
\hline \multicolumn{10}{|c|}{ Hormonlu gida } & c308. \\
\hline \multicolumn{10}{|c|}{ Tarımsal ilaç kalıntılı gıda } & c309. \\
\hline \multicolumn{10}{|c|}{ Genetiği ile oynanmıș gıda } & $\mathrm{c} 310$. \\
\hline \multicolumn{10}{|c|}{ Katkı maddesi içeren gida } & $\mathrm{c} 311$. \\
\hline \multicolumn{10}{|c|}{ Hayvansal hastalıklı gida (deli dana, kuş gribi) } & $\mathrm{c} 312$. \\
\hline \multicolumn{10}{|c|}{ Son kullanma tarihi geçmiş gida } & c313. \\
\hline \multicolumn{10}{|c|}{ Etiketi olmayan gida } & c314. \\
\hline \multicolumn{10}{|c|}{ Helal olmayan gida } & $\mathrm{c} 315$. \\
\hline \multicolumn{10}{|c|}{$\begin{array}{l}\text { 19. Gıda ürünleri satın alırken gıda güvenliği ile ilgili aşağıdaki kriterler hakkında } \\
\text { bilgiye sahip olup olmama durumunuz nedir? }\end{array}$} & \\
\hline \multicolumn{4}{|c|}{ HACCP } & $1>\mathrm{H}$ & vet & $0>$ Hay & & & & c316. \\
\hline EUREPG & & & & $1>1$ & ivet & $0>$ Hay & & & & c317. \\
\hline ISO22000 & & & & $1>1$ & vet & $0>$ Hay & & & & c318. \\
\hline ISO9001 & & & & $1>1$ & vet & 0>Hay & & & & $c 319$. \\
\hline ORGANİ & $\overline{\mathrm{K} / \mathrm{EKOLC}}$ & JiंK GI & $\overline{\mathrm{DA}}$ & $1>E$ & vet & $0>$ Hayı & & & & c320. \\
\hline COĞRAF & İ İŞARE] & LI GID & & $1>\mathrm{F}$ & vet & $0>$ Hay & & & & c321. \\
\hline HELAL G & IDA & & & $1>\mathrm{E}$ & vet & $0>$ Hay & & & & c322. \\
\hline $\begin{array}{l}\text { 20. Helal } \\
\text { Kat1lmiyor }\end{array}$ & $\begin{array}{l}\text { Gida den } \\
\text { rum, } \quad 3\end{array}$ & $\begin{array}{l}\text { ildiği z: } \\
>\text { Orta }\end{array}$ & $\begin{array}{l}\operatorname{man} n \\
4>\mathrm{Ge}\end{array}$ & $\begin{array}{l}\text { e anlıyo } \\
\text { nellikle } 1\end{array}$ & $\begin{array}{l}\text { sunuz? } \\
\text { Cat1liyor }\end{array}$ & $\begin{array}{r}1>\mathrm{K} \\
\text { rum } \\
5\end{array}$ & $\begin{array}{l}\text { sinlikle } 1 \\
>\text { Kesinli }\end{array}$ & $\begin{array}{l}\text { at1lmiyoru } \\
\text { le katıliyo }\end{array}$ & $\begin{array}{l}\mathrm{m} 2>\mathrm{Az} \\
\text { rum }\end{array}$ & \\
\hline Ürünün do & muz katk & 111 olma & d.ğını i & fade ediy & & & & & & c323. \\
\hline Ürünün all & kol içerm & ediğini & fade ed & iyor & & & & & & c324. \\
\hline Ürünün M & üslüman & kişiler $\mathrm{t}$ & rafinda & n üretild & ğini ifa & de ediyc & & & & $\mathrm{c} 325$. \\
\hline Ürünün İsl & lami usul & ere gör & $\overline{\text { üretild }}$ & iğini ifac & e ediyo & & & & & $\mathrm{c} 326$. \\
\hline Ürünün sa & ğliklı old & dğunu it & ade edi & yor. & & & & & & c327. \\
\hline Ürünün da & ha lezzet & i olduğ & nu ifac & e ediyor & & & & & & c328. \\
\hline
\end{tabular}




\begin{tabular}{|c|c|}
\hline \multirow[b]{2}{*}{$\begin{array}{l}\text { Ürünün yüksek fiyatlı olacağını ifade ediyor } \\
\text { Helal Gıda; bitkisel, hayvansal, kimyasal yada mikrobiyal kaynaklı olsun, gıda } \\
\text { ürünlerinin; hammadde, işlem yardımcı maddeleri, bileşenleri, katkı maddeleri, işleme } \\
\text { metotları, işletme koşulları ve dahi ambalajlarının İslâmî kurallara uygunluğunun } \\
\text { ifadesidir. }\end{array}$} & c329. \\
\hline & \\
\hline $\begin{array}{l}\text { 21-30. Soruları değerlendiriniz: } 1>\text { Kesinlikle katılmiyorum } 2>\text { Az Katılmiyorum, } 3 \\
>\text { Orta } 4>\text { Genellikle Kat1liyorum } 5>\text { Kesinlikle kat1liyorum }\end{array}$ & \\
\hline 21. Satın aldığınız ürünün helal olup olmadığına dikkat ediyor musunuz? & c330. \\
\hline $\begin{array}{l}\text { 22. Satın aldığınız şekerlemelerde (özellikle jöle kıvamında olanlarda) domuzdan } \\
\text { elde edilmiş jelatin maddesi olabileceğini biliyor musunuz? }\end{array}$ & c331. \\
\hline 23. Peynirin domuz kaynaklı mayalarla üretilmiş olabileceğini biliyor musunuz? & c332. \\
\hline 24. Gazlı içeceklerde \% 0,5 oranında alkol olabileceğini biliyor musunuz? & c333. \\
\hline 25. Ekmek ve pastalarda domuz yağı olabileceğini biliyor musunuz? & $\mathrm{c} 334$. \\
\hline 26. Helal gıda sertifikası ifadesini duydunuz mu? & $\mathrm{c} 335$. \\
\hline \multicolumn{2}{|l|}{ 27. Duydunuz ise Helal Gıda Sertifikası nedir? } \\
\hline Dine uygun üretildiğini gösteren işaret & $\mathrm{c} 336$. \\
\hline Sağlık ve kalite standardına uygun üretim & $\mathrm{c} 337$. \\
\hline Helal olan ürünün garantisi & $\mathrm{c} 338$. \\
\hline Güvenilerek tüketilebilecek ürün & c339. \\
\hline $\begin{array}{l}\text { Katkısız, doğal ürün } \\
\text { 28. Satın aldıŏınız ürünlerde helal gıda sertifikası olmasına dikkat edivor musunuz? }\end{array}$ & $\mathrm{c} 340$. \\
\hline 28. Satın aldığınız ürünlerde helal gıda sertifikası olmasına dikkat ediyor musunuz? & $\mathrm{c} 341$. \\
\hline \multicolumn{2}{|l|}{$\begin{array}{l}\text { 29. Satın aldığım ürünün helal gıda sertifikalı olup olmadığına dikkat ediyorum. } \\
\text { Çünkü }\end{array}$} \\
\hline Dini sebeplerden dolay1 & $\mathrm{c} 342$. \\
\hline Daha güvenilir & $\mathrm{c} 343$. \\
\hline Daha sağlıklı & $\mathrm{c} 344$. \\
\hline Daha lezzetli & c345. \\
\hline \multirow{2}{*}{$\begin{array}{l}\text { Daha kaliteli } \\
\text { 30. Helal sertifikalı gıda tüketmiyorum. Cünkü }\end{array}$} & c346. \\
\hline & \\
\hline Hiç duymadım & c347. \\
\hline Çok pahalı & $\mathrm{c} 348$. \\
\hline Ürünleri bulamıyorum & c349. \\
\hline Sertifikaya güvenmiyorum & $\mathrm{c} 350$. \\
\hline Tadını beğenmiyorum & $\mathrm{c} 351$. \\
\hline Hepsinin helal olduğunu düşünüyorum & $\mathrm{c} 352$. \\
\hline 31. Daha önce Helal sertifikalı ürün satın aldınız mı? & $\mathrm{c} 353$. \\
\hline $\begin{array}{ll}\text { 1 }>\text { Hiç almadım. } & \text { 2> Birkaç kere aldım } \quad 3>\text { Ara sıra satın alırım } \\
\text { 4> Genellikle satın alırım } & 5>\text { Sadece helal sertifikalı ürün satın alırım }\end{array}$ & \\
\hline $\begin{array}{l}\text { 32.Hangi ürünlerde helal sertifikasının olmasını istersiniz. } \\
\text { istemem } \quad 2>\mathrm{Az} \text { isterim, } 3>\text { Orta } \quad \text { 4> Genellikle isterim } \quad \text { 5>Kesinlikle isterim }\end{array}$ & \\
\hline Kirmızı et & c354. \\
\hline Beyaz et & $\mathrm{c} 355$. \\
\hline Sucuk, Salam, Sosis & c356. \\
\hline Yoğurt & $\mathrm{c} 357$. \\
\hline Süit & c358. \\
\hline Peynir & $\mathrm{c} 359$. \\
\hline Unlu Mamuller (Ekmek,pasta) & $\mathrm{c} 360$. \\
\hline Dondurma & $\mathrm{c} 361$. \\
\hline Şekerleme & c362. \\
\hline Döner & $\mathrm{c} 363$. \\
\hline 33. Aşağıdaki ürünlerden ayda ne kadar miktarda tükettiğinizi yazınız. & \\
\hline \begin{tabular}{|l|l|r} 
Ürünler & Helal Sertifikasız & Helal Sertifikalı
\end{tabular} & \\
\hline
\end{tabular}




\begin{tabular}{|c|c|c|c|c|c|}
\hline & Kg/adet/lt & $€$, EUR & $\mathrm{Kg} / \mathrm{adet} / \mathrm{lt}$ & \multicolumn{2}{|c|}{$€$, EUR } \\
\hline Kırmızı et & c364. & c365. & c366. & \multicolumn{2}{|c|}{ c367. } \\
\hline Beyaz et & c368. & $\mathrm{c} 369$. & c370. & \multicolumn{2}{|l|}{ c371. } \\
\hline $\begin{array}{l}\text { Sucuk, Salam, } \\
\text { Sosis }\end{array}$ & $\mathrm{c} 372$. & c373. & c374. & \multicolumn{2}{|l|}{$\mathrm{c} 375}$. \\
\hline Yoğurt & $\mathrm{c} 376$. & c377. & c378. & \multicolumn{2}{|l|}{ c379. } \\
\hline Süt & $\mathrm{c} 380$. & $\mathrm{c} 381$. & $\mathrm{c} 382$. & \multicolumn{2}{|l|}{$\mathrm{c} 383}$. \\
\hline Peynir & c384. & c385. & c386. & \multicolumn{2}{|l|}{ c387. } \\
\hline $\begin{array}{l}\text { Unlu } \\
\text { Mamuller } \\
\text { (Ekmek,pasta) }\end{array}$ & c388. & c389. & c390. & \multicolumn{2}{|l|}{ c391. } \\
\hline Dondurma & $\mathrm{c} 392$. & c393. & c394. & \multicolumn{2}{|l|}{ c395. } \\
\hline Şekerleme & c396. & c397. & c398. & \multicolumn{2}{|l|}{ c399. } \\
\hline Döner & $\mathrm{c} 400$ & $\mathrm{c} 401$ & $\mathrm{c} 402$. & \multicolumn{2}{|l|}{ c403. } \\
\hline \multicolumn{6}{|c|}{$\begin{array}{l}\text { 34. Satın aldığınız ürünün güvenilir bir Helal Sertifikası olması durumunda ne } \\
\text { kadar fazla ödemek istersiniz ? (\%) }\end{array}$} \\
\hline \multicolumn{5}{|c|}{ Kirmizi et } & c404. \\
\hline \multicolumn{5}{|c|}{ Beyaz et } & $\mathrm{c} 405$. \\
\hline \multicolumn{5}{|c|}{ Sucuk, Salam, Sosis } & $\mathrm{c} 406$. \\
\hline \multicolumn{5}{|c|}{ Yoğurt } & c407. \\
\hline \multicolumn{5}{|l|}{ Süt } & c408. \\
\hline \multicolumn{5}{|c|}{ Peynir } & c409. \\
\hline \multicolumn{5}{|c|}{ Unlu Mamuller (Ekmek,pasta) } & $\mathrm{c} 410$. \\
\hline \multicolumn{5}{|c|}{ Dondurma } & c411. \\
\hline \multicolumn{5}{|l|}{ Şekerleme } & $c 412$. \\
\hline \multicolumn{5}{|c|}{ Döner } & c413. \\
\hline \multicolumn{5}{|c|}{ 35. Helal gıda sertifikasyonu ile ilgili önerileriniz? } & $c 414$. \\
\hline
\end{tabular}




\section{Erklärungen}

1. Hiermit erkläre ich, dass diese Arbeit weder in gleicher noch in ähnlicher Form bereits anderen Prüfungsbehörden vorgelegen hat. Weiter erkläre ich, dass ich mich an keiner anderen Hochschule um einen Doktorgrad beworben habe.

Göttingen, den

(Unterschrift)

2. Hiermit erkläre ich eidesstattlich, dass diese Dissertation selbständig und ohne unerlaubte Hilfe angefertigt wurde.

Göttingen, den

(Unterschrift) 


\section{Tuba Pekkirbizli}

Christophorusweg 12/602

37075 Göttingen

Telefon: $0551 / 39-4869$

Mobil: 0176/ 20922159

E-Mail: ptuba@uni-goettingen.de

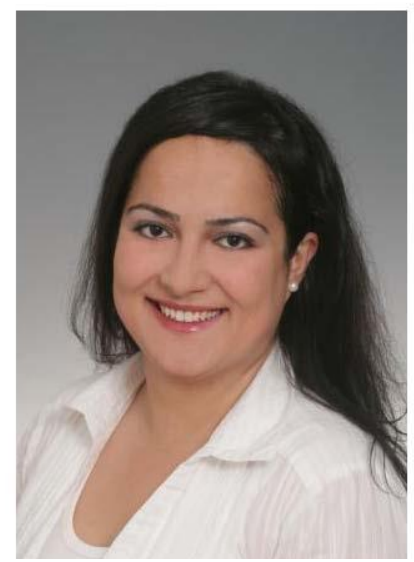

\section{PERSÖNLICHES:}

Familienname:

Pekkirbizli

Vorname:

Tuba

Geburtsdatum:

13.04.1982

Geburtsort:

Konya (Türkei)

Nationalität:

türkisch

Familienstand:

ledig

\section{AUSBILDUNG:}

09/1993-06/1996 :

09/1996- 06/2000:

10/2001- 06/2005 :
Bahcelievler Primär-Schule / Türkei

Anatolien-Lehrer-Oberschule Ankara-Zentrum /Türkei

Universitätsstudium an der Universität Ankara,

Landwirtschaftliche Fakultät

2001-2004: Tierproduktion

2004-2005: Agrarökonomie

Titelbezeichnung: Agrar-Ingenieurin

Promotion am Department für Agrarökonomie und Rurale

Entwicklung, Lehrstuhl Betriebswirtschaftslehre des Agribusiness bei Prof. Theuvsen

Schwerpunkt: Lebensmittelqualität und Sicherheit in der EU Konsequenzen und Anpassungsstrategien für Unternehmen der Agrarund Ernährungswirtschaft in der Türkei 


\begin{tabular}{|c|c|}
\hline \multirow{2}{*}{ 05/2001 - 09/2001: } & Vollzeittätigkeit im Ibni-Sina-Krankenhaus in Ankara \\
\hline & Tätigkeitsbereich: Service, Verwaltung und Rechnungswesen \\
\hline 09/2002 - 06/2003: & $\begin{array}{l}\text { Einmal pro Woche ganztägiger Besuch eines Versuchs- } \\
\text { bauernhofs an der Universität Ankara/Türkei }\end{array}$ \\
\hline $2003-2005:$ & $\begin{array}{l}\text { Ehrenamtliche Mitarbeiterin bei der TEMA Founda- } \\
\text { tion (The Turkish Foundation for Combating Soil } \\
\text { Erosion, for Reforestation and the Protection of } \\
\text { Natural Habitats) }\end{array}$ \\
\hline \multirow[t]{2}{*}{ 07/2003 - 08/2003: } & $\begin{array}{l}\text { Praktikum am Institut für Tierzucht \&Haustiergenetik, } \\
\text { Georg- August-Universität Göttingen }\end{array}$ \\
\hline & $\begin{array}{l}\text { Tätigkeitsbereich: Produktionssysteme der Nutztier- } \\
\text { haltung, Fortpflanzungsbiologie und Biotechnologie, } \\
\text { Ökologie der Nutztierhaltung, Aquakultur, z.T. in } \\
\text { Zusammenarbeit mit dem Tierärztlichen Institut und } \\
\text { dem Institut für Agrarökonomie }\end{array}$ \\
\hline \multirow[t]{2}{*}{ 07/2004 - 08/2004: } & $\begin{array}{l}\text { Praktikum am Institut für Tierzucht \& Haustiergenetik, } \\
\text { Georg-August-Universität Göttingen }\end{array}$ \\
\hline & $\begin{array}{l}\text { Tätigkeitsbereich: Embryogewinnung, Absetzversuch mit } \\
\text { Ziegenlämmern, genetische Parasitenresistenz von Puten }\end{array}$ \\
\hline 03.07.2006 - 14.07.2006: & $\begin{array}{l}\text { Second Summer School Cracow; Thema: "From typical to } \\
\text { new food products in Agri-food industry" }\end{array}$ \\
\hline
\end{tabular}

Tätigkeitsbereich: Service, Verwaltung und Rechnungswesen

Einmal pro Woche ganztägiger Besuch eines Versuchsbauernhofs an der Universität Ankara/Türkei

Ehrenamtliche Mitarbeiterin bei der TEMA Foundation (The Turkish Foundation for Combating Soil Erosion, for Reforestation and the Protection of Natural Habitats)

Praktikum am Institut für Tierzucht \&Haustiergenetik Tätigkeitsbereich: Produktionssysteme der Nutztierhaltung, Fortpflanzungsbiologie und Biotechnologie, Ökologie der Nutztierhaltung, Aquakultur, z.T. in Zusammenarbeit mit dem Tierärztlichen Institut und dem Institut für Agrarökonomie

Praktikum am Institut für Tierzucht \& Haustiergenetik, Tätigkeitsbereich: Embryogewinnung, Absetzversuch mit Ziegenlämmern, genetische Parasitenresistenz von Puten new food products in Agri-food industry"

\section{Job-Erfahrungen}

01.05.2007 - 01.10.2007: Studentische Hilfskraft, Fakultät für Agrarwissenschaften, Department für Agrarökonomie und Rurale Entwicklung, Universität Göttingen.

13.10.2008 - 11.10.2009: $\quad$ Studentische Hilfskraft, Studentenwerk Göttingen.

01.06.2008 - 30.07.2010: Produktionshelferin, CTS Logistik Personal Service GmbH

01. 08.2010 - 30.06.2011: Wissenschaftliche Hilfskraft am Forschungszentrum „Molekularphysiologie des Gehirns“ 
24.04.2011 - 10.05.2011: Übersetzerin und Betreuerin bei den „World Children Games“ in Ankara/Türkei

13.07.2011 - 22.10.2011: $\quad$ Ferienhelferin in der Produktion bei der Volkswagen in Emden, eingesetzt durch die Autovision AG

13.11.2011 - 19.11.2011: $\quad$ Betreuerin des Messestandes von CONLINK, Agritechnica 2011, Hannover.

13.11.2012 - 16.11.2012: $\quad$ Betreuerin des Messestandes von ELANCO Animal Health, Eurotier 2012, Hannover

01.10.2013 - 31.03.2014: Wissenschaftliche Mitarbeiterin an BWL des Agribusiness Universität Göttingen

BESONDERE KENNTNISSE:

IT-Kenntnisse:

Sprachkenntnisse:

Hobbys/Interessen:

Göttingen, 20. Oktober 2014

(Tuba Pekkirbizli)
Umfassende Kenntnisse in der Anwendung des MS-Office-Pakets (Word, Excel, Powerpoint), und SPSS

Türkisch, Deutsch, Englisch

- Taekwondo (3. Dan, Regionale Kampfrichterin)

- 2000 - 2005: Organisatorin von verschiedenen Taekwondo- Veranstaltungen

- Baglama spielen (türkisches Musikinstrument)

- Tanzen 